\title{
Cliff ecology: Extent, biota, and recreation of cliff environments in the New River Gorge, WV
}

Peter W. Clark

West Virginia University

Follow this and additional works at: https://researchrepository.wvu.edu/etd

\section{Recommended Citation}

Clark, Peter W., "Cliff ecology: Extent, biota, and recreation of cliff environments in the New River Gorge, WV" (2012). Graduate Theses, Dissertations, and Problem Reports. 741.

https://researchrepository.wvu.edu/etd/741

This Thesis is protected by copyright and/or related rights. It has been brought to you by the The Research Repository @ WVU with permission from the rights-holder(s). You are free to use this Thesis in any way that is permitted by the copyright and related rights legislation that applies to your use. For other uses you must obtain permission from the rights-holder(s) directly, unless additional rights are indicated by a Creative Commons license in the record and/ or on the work itself. This Thesis has been accepted for inclusion in WVU Graduate Theses, Dissertations, and Problem Reports collection by an authorized administrator of The Research Repository @ WVU. For more information, please contact researchrepository@mail.wvu.edu. 


\title{
CLIFF ECOLOGY: EXTENT, BIOTA, AND RECREATION OF CLIFF ENVIRONMENTS IN THE NEW RIVER GORGE, WV
}

\author{
Peter W. Clark \\ Thesis submitted to the \\ College of Arts and Sciences \\ at West Virginia University \\ in partial fulfillment of the requirements \\ for the degree of \\ Master of Arts \\ in \\ Geography \\ Amy Hessl, Ph.D., Chair \\ David Smaldone, Ph.D. \\ J. Steven Kite, Ph.D.
Department of Geology and Geography
Morgantown, West Virginia 2012

Keywords: New River Gorge, Cliff Ecology, Lichens, Bryophytes, Vascular Plants, Rock Climbing, Impacts 


\title{
Abstract
}

\section{Cliff Ecology:}

\section{Extent, Biota, and Recreation of Cliff Environments in the New River Gorge, WV}

\author{
Peter W. Clark
}

The New River Gorge National River (NERI) contains an extensive network of exposed cliff-forming sandstone units, the most extensive in West Virginia and possibly within the entire Appalachian range. These cliff resources are critical to NERI's national significance, and contain specialized and potentially rare plant communities (Vanderhorst 2001; Mahan 2004; Vanderhorst, Jeuck, and Gawler 2007). This project investigates the spatial distribution of cliffs, associated plant (vascular and non-vascular) and lichen communities, and the impacts to cliff environments caused by recreational rock climbing.

Using LiDAR in a GIS, we mapped all cliffs in the northern extent of NERI, from Keeney's Creek to the Hawks Nest Dam. We randomly selected 36 potential cliff outcrops along gorge slopes to measure structure and inventory cliff face species along all outcrop-forming sandstones. We also sampled 111 Nuttall Sandstone cliffs desirable for rock climbing to assess impacts to cliff environments at three positions: cliff base, face, and top. We randomly selected 79 established rock climbs (experimental) stratified by climb difficulty, potential use intensity, and aspect. In addition, we selected 32 unclimbed sites (control) deemed climbable and stratified by estimated difficulty and aspect. We measured species richness, soils depths, hardened zone (compacted area) lengths, and evidence of anthropogenic disturbance to analyze recreational impacts by climb difficulty, use intensity, and climb style ("traditional" or "sport").

Based on LiDAR, we estimate that there are 97 linear kilometers of exposed sandstone cliffs in the northern extent of NERI. Nuttall Sandstone differs in extent, structure and competence from the Raleigh, Guyandot, and Pineville Sandstones. Incompetent cliffs are more heterogeneous and sustain greater vascular species richness and frequency compared to sites desirable for rock climbing. Stepwise regression indicates $40 \%$ of overall cliff face species richness is determined by cliff angle and topography. We recorded 249 total species on cliff faces plus an additional 109 on cliff tops and base. Total species richness on cliff face ranges from $0-49$. Common cliff face plants include: Asplenium montanum Wild., Betula lenta L., Lasallia pennsylvanica (Hoffm.) Llano, Phsycia subtilis Degel., Leucobryum glaucum (Hedw.) Ångstr., and Dicranella heteromalla (Hedwig) Schimper. Species of special interest include: Danthonia sericea Nutt., Dichanthelium acuminatum (Sw.) Gould \& C.A. Clark ssp. columbianum, Chrysothrix susquehannensis Lendemer \& Elix, Umbilicaria americana Poelt \& T.H. Nash, Dicranum condensatum Hedw., and Brothera leana (Sull.) Müll. Hal.

Impacts to cliff environments from rock climbing are conditioned by climb difficulty, use intensity, and to some extent, climb style. Climb difficulty is highly correlated with cliff structure, with significant declines in topographic frequency and steeper cliff angles associated with more difficult climbs $\left(\mathrm{r}^{2}=0.63 ; P<0.01\right)$. Cliff face species richness declines with increases in climb difficulty (climbed or unclimbed) as well as with increased use intensity. A general linear model based on 
difficulty and use intensity explains $50 \%$ of the variability in total cliff face species richness. Of all cliff positions we investigated, cliff bases are most impacted by climbing, regardless of use intensity, difficulty, or style. Impacts to cliff tops are uncommon and are confined to low difficulty, popular, traditional climbs.

Sites desirable for rock climbing represent a subset of cliffs in NERI, differing from randomly selected and incompetent cliffs in structure and vascular richness and abundance. Rock climb difficulty (e.g., cliff structure) and use intensity are clear predictors of diversity and can be used to guide management. Future development of climbs on competent, low angle cliffs should be limited to preserve the most diverse environments. Cliff bases are the most consistently impacted, where beginner level climbs sustain the greatest impacts to soils, bryophyte species richness, and hardened zone lengths. Impacts to cliff tops are infrequent, occurring on less that $20 \%$ of sites and are confined to a subset of climbing (classified as: high use, traditional, <5.9). To prevent further impacts to sensitive cliff tops, management should target current and future beginner level, highly popular, traditional style climbs and establish a perimeter to impede enhanced impacts. We suggest that trails at base and top be rerouted away from cliffs into the contiguous forest to limit unnecessary traffic along sensitive and unique cliff edges. We recommend the judicious placement of climbing anchors at moderate to high use sites, specifically placed $>2 \mathrm{~m}$ below cliff top above which height diversity is greatest. In addition, we recommend outreach to educate climbers about the negative effects of topping out (climbing on the top of the cliff rather than using anchors). Similarly, other recreational uses at cliff tops should be limited, especially trails and lookouts. 


\section{Table of Contents}

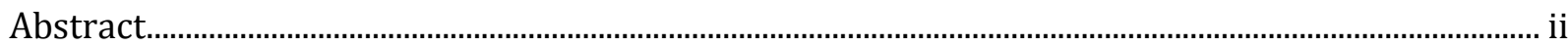

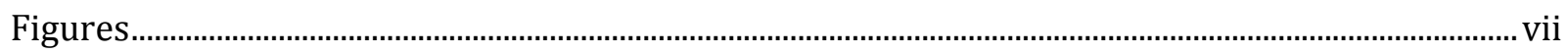

Chapter One

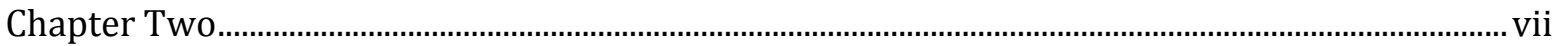

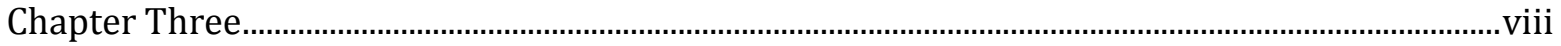

Appendix Chapter Two.......................................................................................................................ii

Appendix Chapter Three...............................................................................................................vii

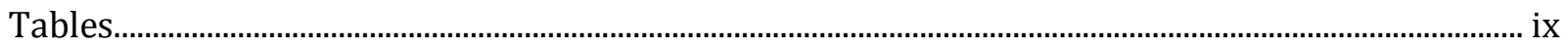

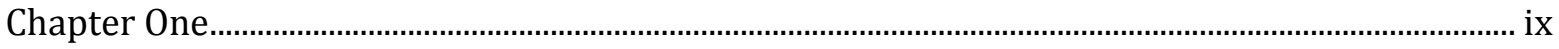

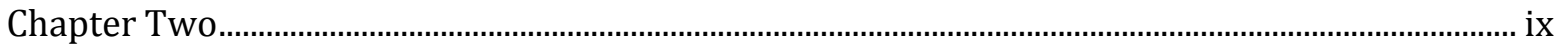

Chapter Three

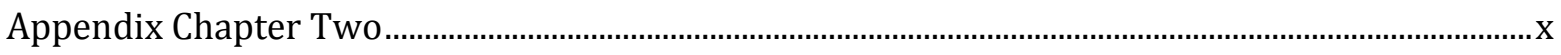

Appendix Chapter Three.........................................................................................................................

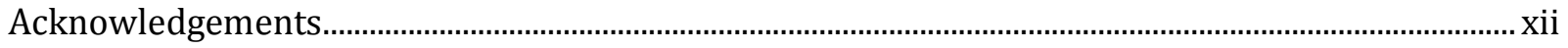

\section{Chapter One}

Literature Review

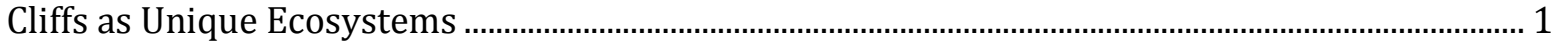

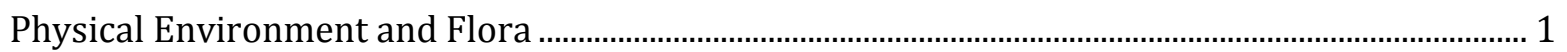

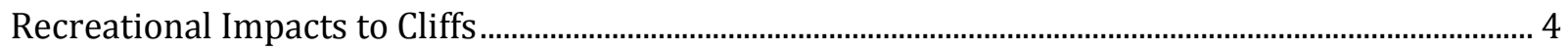

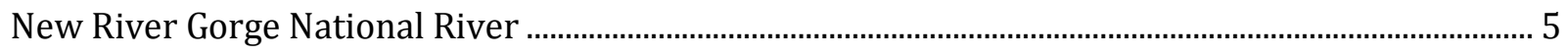

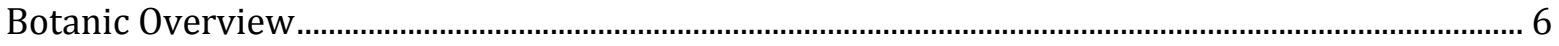

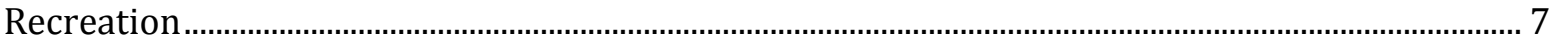

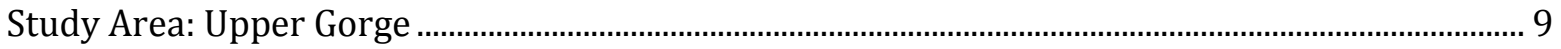

\section{Chapter Two}

The Effects of Rock Climbing on Cliff Ecosystems in the New River Gorge, WV ...........11

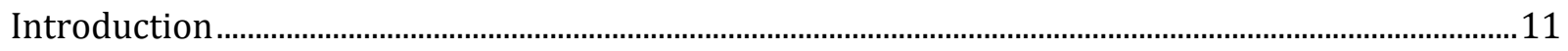

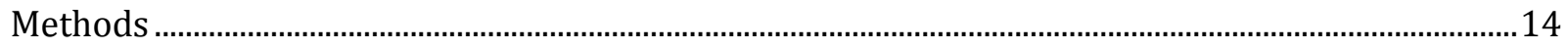

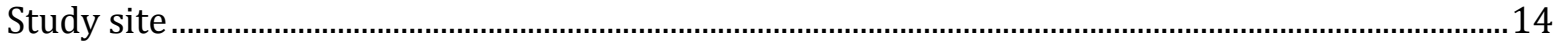

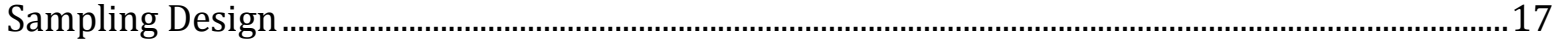




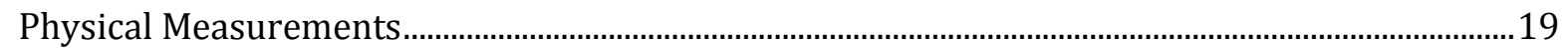

Vegetation Sampling ..................................................................................................................... 19

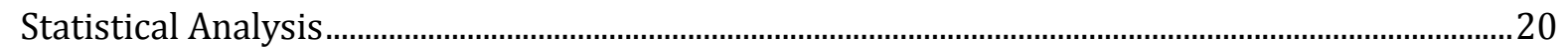

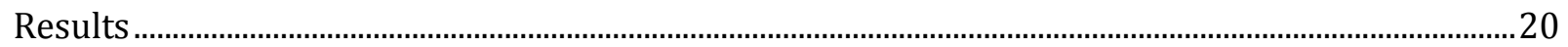

Cliff Structure

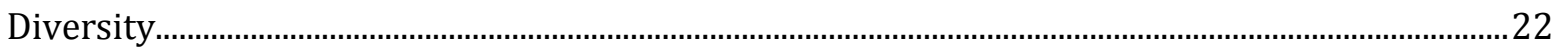

Face

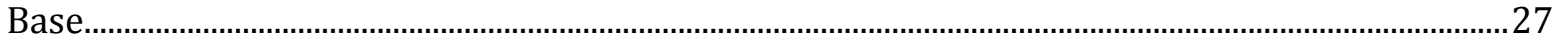

Тор

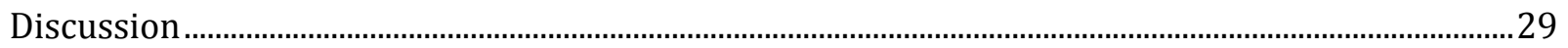

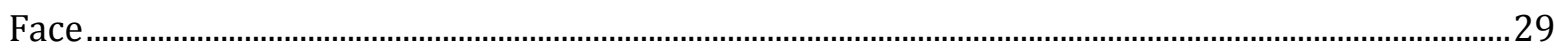

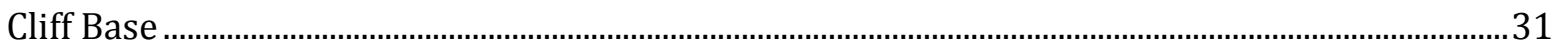

Cliff Top

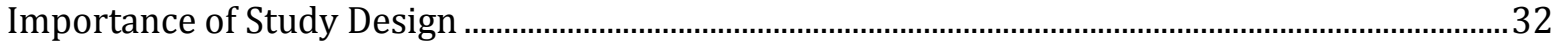

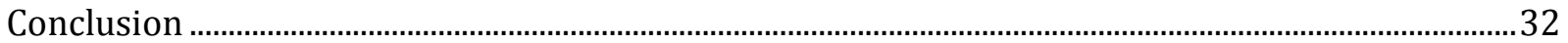

\section{Chapter Three}

Spatial, Structural, and Ecological Inventory of Cliff Environments in the New River

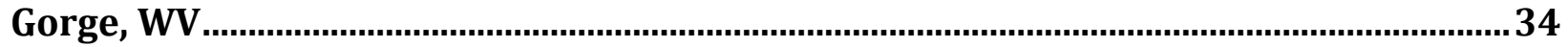

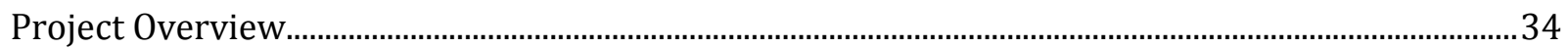

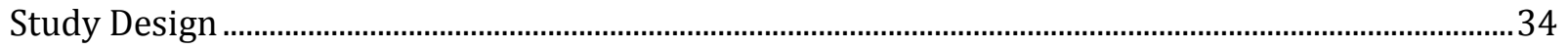

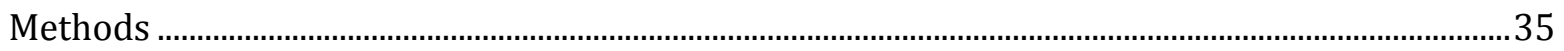

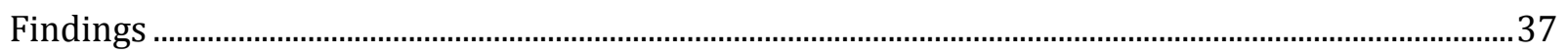

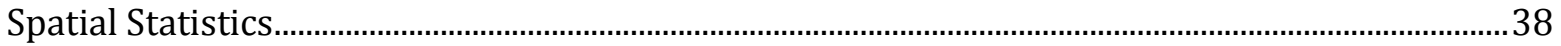

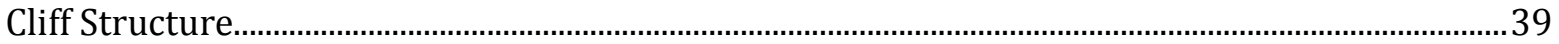

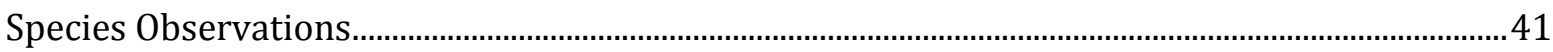

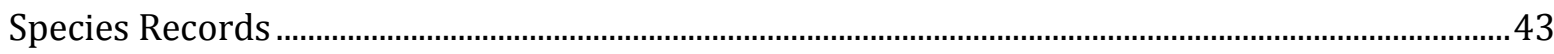

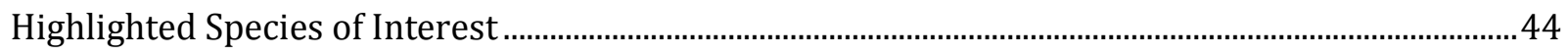

Future Work

\section{Chapter Four}

Project Summary and Management Recommendations ....................................................51 


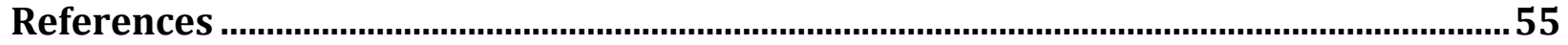

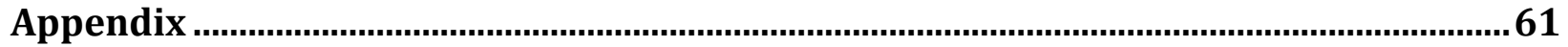

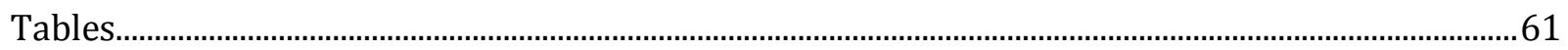

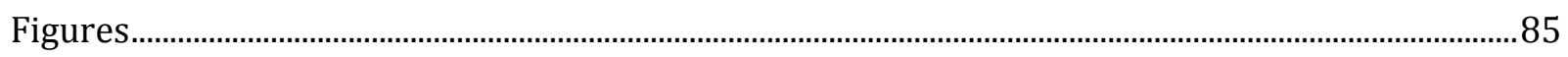




\section{Figures}

\section{Chapter One}

Figure 1.1: Frequency of rock climbs established in a cliff sector, as described by Williams (2010).. 8

Figure 1.2a-b: Frequency of rock climbs a) climb difficulty (YDS) and b) climb difficulty and climb style (Graydon \& Hanson, 1997; Williams 2010).

Figure 1.3a-b: Frequency of rock climbs a) star value (e.g., popularity) and b) star value and climb style (Graydon \& Hanson, 1997; Williams 2010).................................................................................. 9

Figure 1.4: Gorge slopes with cliff forming sandstone beds highlighted .................................................. 9

\section{Chapter Two}

Figure 2.1: Figure visually describing Hypothesis One .13

Figure 2.2: Figure visually describing Hypothesis Two

Figure 2.3: Figure visually describing Hypothesis Three

Figure 2.4: The study area, (a) located in southern West Virginia in (b) the New River Gorge

National River. (c) All study sites were located in the northern section of the gorge near Fayetteville, WV on Nuttall Sandstone cliffs.

Figure 2.5: Field study design.

Figure 2.6: a) the biologically rich cliff apex with b) anchors placed below cliff top preventing impacts from trampling. Arrows point to anchors.

Figure 2.7: Linear relationship between climb difficulty (YDS) and cliff angle (degrees from level ground). $\mathrm{r}^{2}=0.63 ; \mathrm{p}=0.000$.

Figure 2.8a-b: Box plots between climb difficulty class and cliff face topography: a) ledge frequency $(>1 \mathrm{~m})$, and b) microtopography frequency. Statistical significance is calculated using KruskalWallis test. Bars that share a letter code are not significantly different from one another at $\alpha=0.05$. Grey boxes represent the interquartile range, horizontal lines are median values, and crosshairs are mean values.

Figures 2.9a-d: Linear relationships between cliff face species richness (SR) on cliff faces across four taxonomic groups (a: total SR; b: vascular SR; c: bryophyte SR; d: lichen SR) and climb difficulty, regardless of site type.

Figure 2.10: Box plots compare species richness (SR) on cliff faces across four taxonomic groups (a: total SR; b: vascular SR; c: bryophyte SR; d: lichen SR) by site type and use intensity class. Climbed sites are signified as grey boxplots, where unclimbed sites contain hash lines. Statistical significance is calculated using Kruskal-Wallis test. Bars that share a letter code are not significantly different from one another at $\alpha=0.05$. Grey boxes represent the interquartile range, horizontal lines are median values, and crosshairs are mean values.

Figure 2.11: a-d: Contour graphs of cliff face SR across four taxonomic groups (a: total SR; b: vascular SR; c: bryophyte SR; d: lichen SR) displayed using use intensity (CUI; y-axis) and climb difficulty (Grade [YDS]; x-axis). CUI values of "0" are unclimbed control sites Figures 2.12a-b: Box plots of (a) litter and (b) organic horizon soil depths ( $\mathrm{cm}$ ) by use Intensity and site Type. Climbed sites are signified as grey boxplots, where unclimbed sites contain hash lines. Statistical significance is calculated using Kruskal-Wallis test. Bars that share a letter code are not 
significantly different from one another at $\alpha=0.05$. Grey boxes represent the interquartile range, horizontal lines are median values, and crosshairs are mean values.

Figure 2.13: Hardened zone lengths at cliff base climbed sites by use intensity class. Statistical significance is calculated using Kruskal-Wallis test. Bars that share a letter code are not significantly different from one another at $\alpha=0.05$. Grey boxes represent the interquartile range, horizontal lines are median values, and crosshairs are mean values.

Figure 2.14: Contour graph of hardened zone length at cliff top by use intensity (CUI; y-axis) and climb difficulty (YDS; $\mathrm{x}$-axis).....

\section{Chapter Three}

Figure 3.1: Generalized stratigraphic column, redrawn from Korus (2002) .............................................35

Figure 3.2: Examples of geologically incompetent cliffs ........................................................................36

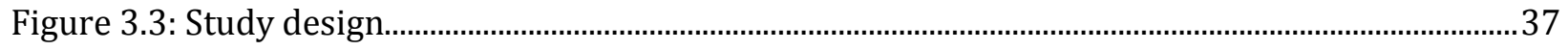

Figure 3.4: A $1 \mathrm{~m} 2$ quadrat positioned on cliff face.................................................................................. 37

Figure 3.5: Digitized cliff outcrops by geology with study sites. Legend: Black polygon is the NERI park boundary. Nodal points are study sites, where blue are randomly selected inventory sites, green are established rock climbs (experimental sites), and red are unclimbed cliffs (control sites). Polylines are clifflines, where Nuttall = brown, Guyandot $=$ dark orange, Raleigh = orange, and

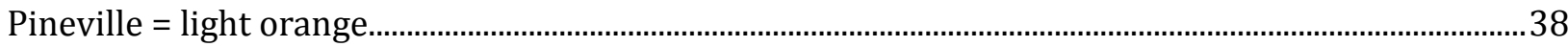
Figure 3.6: Cliff size (length in $\mathrm{m}$ ) derived from a GIS. Size classes consist of: Class $1=<49 \mathrm{~m}$, Class $2=50$ to $149 \mathrm{~m}$, Class $3=150$ to $499 \mathrm{~m}$, Class $4=500$ to $1499 \mathrm{~m}$, Class $5=>1500 \mathrm{~m}$. 39

Figure 3.8: Cliff height in meters between sandstone types. Box plots that share a letter code are not significantly different at $\alpha=0.05$ (ANOVA)

Figure 3.7: Cliff slope in degrees between sandstone types. Box plots that share a letter code are not significantly different at $\alpha=0.05$ (ANOVA)

Figure 3.10: Macrotopographic frequency (summed at site level) between sandstone types. Box plots that share a letter code are not significantly different at $\alpha=0.05$ (ANOVA)..................................40 Figure 3.9: Microtopographic frequency (averaged at quadrat level) between sandstone types. Box plots that share a letter code are not significantly different at $\alpha=0.05$ (ANOVA). 40 Figure 3.11: Vascular species richness and frequency on cliffs sites selected for rock climbing (climbed), randomly selected competent cliffs (random), and randomly selected incompetent cliffs (incompetent). Box plots that share a letter code are not significantly.

\section{Appendix Chapter Two}

Appendix Figure 2. 1: Cliff base hardened zone length (m) compared by climb style (e.g., sport and traditional). Statistical significance is calculated using Kruskal-Wallis test. Columns that share a letter code are not significantly different from one another at $\alpha=0.05$ Appendix Figure 2. 2: Litter and organic soils depths at cliff base compared by site type. Columns that share a letter code are not significantly different from one another at $\alpha=0.05$.

\section{Appendix Chapter Three}


Appendix Figure 3. 2: Two cliffs partially or fully formed by manmade processes. 88

Appendix Figure 3. 3: Stepwise regression using Minitab software. Predictors: cliff angle, macrotopographic frequency, microtopographic frequency and volume, aspect and elevation. Response: species richness by taxonomic group 89 Appendix Figure 3. 4: Multiple linear regression for species richness by taxonomic group (response) using significant predictors from a stepwise regression using Minitab software .92 Appendix Figure 3. 5: Dichanthelium acuminatum (Sw.) Gould \& C.A. Clark ssp. columbianum established on the cliff top of a Nuttall Sandstone cliff (site N214) . .96

Appendix Figure 3. 6: Carex appalachica J. Webber \& P.W. Ball established on the cliff base of a Nuttall Sandstone cliff (site N49).

Appendix Figure 3. 7: Carex tonsa (Fernald) E.P. Bicknell var. rugosperma (Mack.) Crinsfound on a disturbed (e.g. manmade), incompetent cliff face 98 Appendix Figure 3. 8: Numerous Carex nigromarginata Schwein. found established on a low angled Raleigh Sandstone cliff (site N326.03) ... 99 Appendix Figure 3. 9: Abundant Chrysothrix susquehannensis Lendemer \& Elix. on an incompetent Pineville Sandstone cliff face 100 Appendix Figure 3. 10: Umbilicaria americana Poelt \& T.H. Nash on a cliff face with parasitized $C$. susquehannensis. 101 Appendix Figure 3. 11: Characteristic neon Chrysothrix insulizans R.C. Harris \& Ladd established at cliff base of site N319.01. 102 Appendix Figure 3. 12: Black, jelly-like Cystocoleus ebeneus (Dillwyn) Thwaites at site N225 ......... 103 Appendix Figure 3. 13: Cliff top habitat for Dicranum condensatum Hedw. found in site N222, with Gaylussacia baccata (Wangenh.) K. Koch, and Kalmia latifolia L 104 Appendix Figure 3.14 Andreaea rothii F.Weber \& D. Mohr established above rock climbing anchors in characteristic habitat. 105 Appendix Figure 3. 15: Characteristic cliff top habitat for Dicranum spurium Hedw. found in site N228. Note most bryophytes present in picture are Leucobrym glaucum (Hedw.) Ångstr. 106

\section{Tables}

\section{Chapter One}

Table 1.1: Descriptive statistics of rock climb in the New River Gorge, derived from Williams (2010). *Sector is defined as a cliff section as described in the climbing guidebook. 8

\section{Chapter Two}

Table 2.1: Number of study sites stratified by site type (climbed vs. unclimbed), use intensity, climb difficulty, and aspect (gorge side).

Table 2.2: Species richness by taxonomic group (total, vascular, bryophyte, and lichen) at each cliff position (cliff base, face, and top). IQR: Interquartile range.

Table 2.3: GLM regression between species richness (SR; response) on cliff faces across four taxonomic groups (total SR, vascular SR, bryophyte SR, and lichen SR) predicted with use intensity (CUI) and climb difficulty (Grade [YDS]). 


\section{Chapter Three}

Table 3.1: Study area descriptive statistics. *Site selection: climbed: 80; unclimbed: 32; random: 10.

Table 3.2: Large scale descriptive statistics of cliffs in NERI derived from a GIS

Table 3.3: Cliff face structural measurements. Significantly different $\alpha=0.05$ (T-test) by geologic competency.

Table 3.4: Number of observations by species, genera, and family. $*=$ Nuttall cliff tops and base from climbing study only

Table 3.5: Species richness statistics by taxonomic group. Site numbers (e.g., N_\#_) are displayed in association with maximum and minimum species richness values............................................................ 41

Table 3.6: Results from multiple linear regressions ...................................................................................42

Table 3.7: Five most common species by taxonomic group. ** Note "unknown crust" demonstrates the frequency and difficulty of sampling and identifying crustose lichens, many of which were too fragmentary to determine. It is unlikely that these fragmentary specimens represent new species records.

\section{Appendix Chapter Two}

Appendix Table 2. 1: Observations of anthropogenic disturbance at three cliff positions (cliff base, face, and top).

Appendix Table 2. 2: Median species richness (SR) and interquartile range (IQR) on cliff faces by difficulty and by taxa. No significant differences are observed between difficulty classes and taxonomic groups

Appendix Table 2. 3: Cliff base soils depths (median values and IQR) at all site controlled by difficulty. Statistical significance is calculated using Kruskal-Wallis test. Columns that share a letter code are not significantly different from one another at $\alpha=0.05$.

Appendix Table 2. 4: Cliff base soils depths and hardened zone lengths (median values and IQR) controlled by difficulty. Statistical significance is calculated using Kruskal-Wallis test between groups within boxes. Groups that share the code "ns" are not significantly different from one another at $\alpha=0.05$.

Appendix Table 2. 5: Cliff base soils depths and hardened zone lengths (median values and IQR) at all site controlled by use intensity. Statistical significance is calculated using Kruskal-Wallis test. Columns that share a letter code are not significantly different from one another at $\alpha=0.05$. .65 Appendix Table 2. 6: Cliff base SR (median values and IQR) across four taxonomic groups at all sites controlled by use intensity. Statistical significance is calculated using Kruskal-Wallis test. Columns that share a letter code are not significantly different from one at $\alpha=0.05$. 66 Appendix Table 2. 7: Cliff base SR (median values and IQR) across four taxonomic groups controlled by difficulty. Statistical significance is calculated using Kruskal-Wallis test between groups within boxes. Groups that share the code "ns" are not significantly different from one another at $\alpha=0.05$. 


\section{Appendix Chapter Three}

Appendix Table 3. 1: Supplementary cliff face structure descriptive statistics by sandstone type. Columns that share a letter code are not significantly different at $\alpha=0.05$ (T-test)...........................68 Appendix Table 3. 2: Complete species list and cliff position where it was observed. Location codes are as follows: $F=$ Cliff Face (all sandstone types), $B=$ Cliff Base (Nuttall Sandstone only); $T=$ Cliff Top (Nuttall Sandstone only) ....................................................................................................................69

Appendix Table 3. 3: Cliff face species by frequency of occurrence .............................................................80

Appendix Table 3. 4: Rare species or species of special interest........................................................................83 


\section{Acknowledgements}

I extend my great appreciation to my advising committee, Drs. Amy Hessl, Dave Smaldone, and J. Steve Kite, for their guidance, support, and patience in seeing this project through to fruition. Their roles and vision as project investigators, along with the efforts of National Park Service biologist John Perez, laid the groundwork for this project allowing me the autonomy to pursue a fascinating study.

This research would not be possible without the financial support from National Park Service, who through a cooperative agreement with West Virginia University funded my GRA. Additionally, this research was graciously funded through the visionaries at the Explorers Club, The Access Fund, and The American Alpine Club.

Many thanks to Dr. Susan Moyle-Studlar, Don Flenniken, and James Vanderhorst for providing their invaluable expertise in Appalachian ecology and the taxonomy of bryophytes, lichens, and vascular plants. This project would not have the taxonomic resolution that it does without their help, and that of Dr. Donna Ford-Werntz, Brian Streets, Elizabeth Byers, and Zach Fowler.

Thank you to the Montane Forest Dynamics Lab and its affiliates for your creativity and direction, notably Tom Saladyga, Stockton Maxwell, Carrie Leland, Josh Wixom, Brad Breslow, and John Burkhart. Your approach planted the seeds for many of the ideas presented here. Thanks also to my outstanding field assistant, Britton Forsyth Van Vleek, and to Katie Jones and all of the undergraduate work-study students for their help.

Thank you to all of the climbers in Fayetteville who shared their expertise about the area and supplied me with many of the necessary tools for this project. I would specifically like to thank Mike Williams for the unprecedented access to his guidebook prior to its release. This afforded me with a wealth of information and was fundamental to my study design. I would also like to thank Gene and Maura Kistler, Kenny Parker, and the New River Alliance of Climbers for their support of this project. Lydia McDonald was amazing in support of this project. Thank you Porter Jerrard, Peili Wren, Elissa Williams, Brooks, Levi Rose, and many others that I will regret leaving out.

Finally, thank you to my family. Turns out you're wonderful. Linnea and Bill Clark are the best scientists around. And thanks to my friends. You've all lent me your ears, your time, and your belief in me. Thank you all. 


\section{CHAPTER ONE}

\section{Literature Review}

\section{Cliffs as Unique Ecosystems}

Until recently, the scientific community expressed little interest in cliff ecosystems. Cliffs were largely overlooked by biologists and ecologists as they represented geological rather than biological habitats. Most literature focused on geological, morphological, or hydrological characteristics of cliffs, but made little mention of the biological resources they harbor (Larson, Matthes, and Kelly 2000). When cliffs were discussed in scientific literature, they were deemed inaccessible, unsafe, or impossible to sample (Larson, Matthes, and Kelly 2000; Attarian and Keith 2008), rather than landscapes with unique environmental conditions (Graham and Knight 2004). Cliffs are not only one of the least-studied ecosystems but also among the least modified features of a landscape. Exploration of these vertical environments has resulted in the discovery of diverse natural communities that contain rare flora and fauna (Oosting and Anderson 1937; Larson and Kelly 1991; Camp and Knight 1998; Larson, Matthes, and Kelly 2000; Larson et al. 2000; Graham and Knight 2004). Globally widespread yet spatially fragmented, cliffs maintain some of the most distinct and unique ecosystems in the world (Larson, Matthes, and Kelly 2000). Regardless of geographic setting, cliffs sustain relict, undisturbed, and often ancient environments (Larson, Matthes, and Kelly 2000; Larson et al. 2000). They are core habitat for species and are frequently refugia from both natural and anthropogenic disturbance for rare flora and fauna. Ancient human populations have used cliffs as dwellings or sacred grounds (Douglass 1929; Larson, Matthes, and Kelly 2000), and many are now highlighted in national parks as tourist destinations. Climate scientists have even used trees growing on cliffs as a proxy for long-term climate reconstructions (Kelly, Cook, and Larson 1994; Maxwell et al. 2009). Environmentally and socially significant, cliffs ecosystems are unique, unexplored facets of the global landscape.

\section{Physical Environment and Flora}

Larson et al. (2000) characterize cliffs as terrain that: (1) is not defined by substrate and may be composed of rock, sand, gravel or other sources; (2) has [a] a level platform, or plateau, at the top (also referred to as cliff edge or cliff top), [b] has a pediment consisting of baserock at the bottom (also referred to as cliff base or talus), [c] has a vertical or non-vertical cliff-face; (3) is $>3$ meters in height; (4) is not defined by slope, but is typically more extreme than $50^{\circ}$ from horizontal. While cliffs may appear sheer and blank, most are topographically heterogeneous, featured on varying spatial scales. Caves, ledges, overhangs, cracks, joints, dihedrals, patina, or pockets are all terms used to describe features commonly occurring on cliffs (Larson, Matthes, and Kelly 2000; Kuntz and Larson 2006a; Kuntz and Larson 2006b; Williams 2010). Cliff features are the basis for cliff ecology as they provide microhabitats and rooting space for vascular and nonvascular plants (Oosting and Anderson 1937; Larson, Matthes, and Kelly 2000; Kuntz and Larson 2006a). Due to the heterogeneous nature of cliffs, highly complex and dissimilar ecosystems may form adjacent to one another. For example, organisms tolerant to heat and desiccation such as lichens may exist on sheer rock walls bordering features such as ledges and cracks which accumulate soils and harbor vascular plants common to wetland environments.

Variability in physical environment can dictate the development of the cliff and associated ecology. Orientation, aspect, solar radiation, moisture, temperature, gravity, and wind are all controlling processes that influence cliff environments. Orientation may affect the total amount of direct 
radiation a cliff surface receives, as well as influencing wind speeds, temperature, and the amount of direct precipitation. Cliff aspect may also influence flora by determining exposure to light, temperature, and evaporation rates (moisture availability). Aspect can determine the amount of solar radiation absorbed and fracturing due to frequency of freeze-thaw events. North-facing cliffs may receive only half of the annual direct insulation that south-facing cliffs do (Larson, Matthes, and Kelly 2000). Owing to height and absence of vegetation, cliffs lack the thermal or evaporative buffer that neighboring forests and soils have (Larson, Matthes, and Kelly 2000). Moisture is also an important contributing factor to cliff ecology. Direct precipitation varies as a product of the orientation and slope, but fog and dew may also contribute to total moisture depending on the moisture-retention properties of the substrate. Specialized cliff dwelling organisms that inhabit caves and overhangs, such as various bryophytes and lichens, rely on fog and dew for survival (Brodo, Sharnoff, and Sharnoff 2001).

Collectively, both the geologic and environmental conditions can influence the establishment of cliff ecosystems. One group of focused on succession on granite outcrops (Oosting and Anderson 1937; Oosting and Anderson 1939; Keever, Oosting, and Anderson 1951). Oosting and Anderson (1937) studied vegetation inhabiting low angled cliffs, and asserted that select lichens and bryophytes found on rock features (e.g., depressions, cracks, ledges) are critical to the early succession by allowing the eventual establishment of higher plants. More recent works indicate that differences in life-form and biomass on cliffs may be the result of a spatially variable habitat quality that changes very slowly. This makes classic theories of succession to explain community structure unnecessary (Bostick 1971; Smiley and George 1974; Larson, Matthes, and Kelly 2000).

Some authors indicate that vegetative communities vary depending on cliff face vertical position (Nuzzo 1996; Larson, Matthes, and Kelly 2000). Nuzzo (1996) demonstrated in her research that $70 \%$ of all species found on cliff faces sampled were recorded within the upper $3 \mathrm{~m}$ of the cliff face (e.g., cliff apex). Kuntz and Larson (2006a) evaluated the role of physical features in the organization of cliff-face vegetation communities by examining large (geographic), local (macrotopographic), and fine scale (microtopographic) rock features. Their results suggest that fine scale microtopographic features are the most important drivers in the establishment of cliffside vegetation, leading to the creation of isolated and distinct cliff-side micro-communities. Graham and Knight (2004) also sampled for vascular plants within various scales $\left(1 \mathrm{~m}^{2}, 20 \mathrm{~m}^{2}\right.$, and $40 \mathrm{~m}^{2}$ ) on cliffs and bases and compared plant richness and diversity among large, medium, and small cliffs as well as non-cliff sites. Their results indicate that species diversity does not increase with cliff size, however richness is positively associated with plots of $>20 \mathrm{~m}^{2}$ scale $(70 \%$ of variability explained) suggesting a species-area relationship at large scale sites. These studies imply that the interactions between biological and geologic factors are highly complex and potentially site specific in determining the development of cliff ecosystems.

The physical environment can also greatly influence the productivity of cliff flora. Vascular plants on cliffs are often described as reduced in size, less vigorous, and with smaller population sizes relative to those not on cliffs (Oosting and Anderson 1937; Larson and Kelly 1991; Larson, Matthes, and Kelly 2000; Larson et al. 2000; Larson 2001; Kuntz and Larson 2006a). Globally on temperate inland cliffs, common genera are Campanula, Asplenium, Sedum, Pellaea, and Polypodium (Larson, Matthes, and Kelly 2000). In the eastern United States, several studies have noted members of the Cupressaceae family (e.g., Juniperus virginiana L., Juniperus ashei J. Buchholz, Thuja occidentalis L.) to be common to cliffs faces and tops, while members of the Pinaceae family (e.g. Pinus, Tsuga) and Quercus genera can be common at the cliff base (Larson, Matthes, and Kelly 2000). In the southeastern United States, various additional plant families have been recorded on cliffs, such as Aspleniaceae, Cystopteridaceae, Araliaceae, Cyperaceae, and Ranunculaceae (Bostick 1971; 
Lammers 1980; Walker 1987). No studies suggest that cliff bases harbor specialized woody plants, however due to accumulated debris, some moss and even vascular wetland species have been noted in select areas at cliff bases (Cox and Larson 1993). Dicranum and Atrichum mosses and Cladonia and Umbilicaria lichens are common cryptogams on cliff environments of temperate North America (Larson, Matthes, and Kelly 2000; Brodo, Sharnoff, and Sharnoff 2001; Vanderhorst, Jeuck, and Gawler 2007).

Research conducted on the Niagara Escarpment, Ontario showed that cliff environments can also harbor ancient forests (Larson and Kelly 1991; Larson 2001). A spatially exhaustive study conducted by Larson et al. (2000) demonstrated that the existence of old trees is not exclusive to the cliffs of the Niagara Escarpment, but part of a global pattern. Larson (2001) also suggests that cliffs may harbor old trees (here, Thuja occidentalis) because: (1) injury or death due to rock fall is sporadic and infrequent; (2) trees are composed of hydraulically independent units that allow mortality in one part of the individual with few negative effects on the remaining parts; (3) trees on cliffs are small, so environmental loadings of ice, snow, and wind are low; (4) slow growth of trees results in greater mechanical strength in the wood. Thus, some trees are well-adapted to survive in seemingly harsh cliff landscapes.

Of cliff dwelling biota, lichens are some of the most prevalent and specialized, and many rely on cliffs as primary habitat (Krajick 1999). Lichens are composed of two completely different organisms, algae or cyanobacteria (photobiont) and fungi (mycobiont), which symbiotically function as one (Hale 1979). Brodo et al. (2001) report over 14,000 lichens that have been recorded globally, inhabiting approximately $8 \%$ of the world's terrestrial surface. The lichen is named for the fungal partner (mycobiont) that comprises most of its structure; the photosynthetic partners (photobionts) are much less diverse with over 25 genera of green algae, and 12 genera of cyanobacteria. Morphologically, lichens are highly diverse due to the complexities of their biology. The major growth forms are: foliose: more or less flattened thallus (lichen body) with easily distinguishable upper and lower surfaces; fruiticose: grow erect or pendent whose thalli, even if flattened, have no clearly distinguishable upper and lower surfaces; crustose: those that simply form crusts over their substrates; squamulose: an intermediate between foliose and crustose growth forms, and leprose: "dust lichens" with little to know thallus structure. (Brodo, Sharnoff, and Sharnoff 2001). External morphology, color, and habitat are helpful in identification of species, but correct identification generally requires microscopic and chemical analysis (Hale 1979).

Lichens can be pioneering organisms, thriving in places where higher plants have difficulty establishing. Specimens are found living on various substrates such as rock, soils, other plants (epiphytic), animals, decaying matter, or anthropogenic structures. In extreme environments like cliffs, mountains, or high latitudes, lichens may be the sole vegetation type present (Hale 1979). Able to survive extreme temperatures, lichens also have the unique ability to quickly absorb available water through their thallus. Many are extremely drought resistant and can survive in dry habitats without water for extended periods. The capacity to absorb moisture from air allows them to grow without the direct flow of water. Some specialized leprose (powdery or dust lichens, e.g., Lepraria or Chrysothrix) cannot absorb liquid water, which makes them particularly suited to grow under overhanging rocks where relative humidity remains high but no direct precipitation occurs. Also they can repel water and avoid becoming saturated (Brodo, Sharnoff, and Sharnoff 2001).

Bryophytes (mosses and liverworts), informally called cryptogams (an obsolete taxonomic category), are plants that reproduce sexually by external fertilization and spores, rather than by internal fertilization and seeds. Bryophytes are nonvascular cryptogams commonly found growing on trees, logs, rocks, soils, and decaying organic matter in habitats ranging from streams to cliffs 
There are about 15,600 species of bryophytes worldwide (Evert and Eichhorn 2013) and distribution patterns are typically broader than those of vascular plants (Studlar and Snider 1989). Bryophytes vary in tolerance to disturbance and climatic stresses. Studlar (1980; 1983) demonstrated the effects of trampling on 6 bryophyte species, noting great variability in resilience and regeneration, indicating disturbance may "select" for certain species which thrive on trails. Moisture requirements and tolerance may also vary, but all bryophytes rely on the presence of liquid water for growth and sexual reproduction. As a result, many thrive in moist areas where they may form tightly clustered community mats or clumps. On cliffs, bryophytes are common to exposed edges on cliff tops, water seeps, and at cliff bases. Studlar and Snider (1989) suggest that caves and rock features on cliffs may harbor rare bryoflora, which may have microhabitats favorable to bryophytes but not to vascular plants. As with lichens, microscopic analysis of the anatomy and reproductive structures is imperative to proper identification of bryophytes

\section{Recreational Impacts to Cliffs}

Recreational activities generally reduce the abundance of vegetation (Marion 1991; Larson, Matthes, and Kelly 2000), but impacts to vegetation can vary based on the type of use, season, and frequency (Hammitt and Cole 1998). Simultaneously, the degree of impact to a given plant species depends on environmental factors such as soil moisture, canopy density, elevation, aspect, microclimate, soil drainage, productivity, vegetation type and also characteristics of a the species itself such as genetic makeup and life cycle (Kuss, Graefe, and Vaske 1990; Attarian and Keith 2008). Marion (2007) notes that some impacts, such as hiking trails may help sustain vegetation because the disturbance (hiking) is confined to a limited area, thereby protecting neighboring areas. Furthermore, some researchers have recognized that low-intermediate levels of disturbance may maximize species richness. This phenomena, known as the Intermediate Disturbance Hypothesis (Ward and Stanford 1983; Dial and Roughgarden 1988; Collins, Glenn, and Gibson 1995), has never specifically been applied to cliff environments.

Of the few disturbances to cliff environments, rock climbing may have the greatest impact but the practice of recreational rock climbing is relatively recent. Climbing has been noted in some cliff areas as early as the mid-1800s, but the advent of nylon ropes and other equipment in the 1950s resulted in rapid expansion in climbing popularity (Larson, Matthes, and Kelly 2000). Additionally, technological advancements in gear safety (e.g., nylon harnesses, removable camming units, fixedbolt protection) between the 1960s and 1980s lead to an explosion in popularity, number of areas developed, and increased accessibility to wider audiences. In the 1990s, the arrival of indoor rock climbing gyms opened climbing to an even wider audience, regardless of skill level or proximity to natural rock. In the United States, there are over 2,000 developed climbing areas, with about half of these occurring on federal lands (Toula 2002; Attarian and Keith 2008). According to the 2011 Outdoor Industry Report, there are approximately 7 million rock climbing participants in the United States (The Outdoor Foundation 2011). The report has identified several sub-groups of climbers (e.g., sport climbing, traditional climbing, bouldering, alpinism, competition, etc.), whose perceptions of use of cliffs may not only be different, but their activities may result in different impacts (Schuster, Thompson, and Hammit 2001).

Of the changes that occur as a result of recreational use, impacts to vegetation are some of the most visible (Hammitt and Cole 1998). The most common impacts from climbing occur from trampling at cliff bases, accessing cliff tops, and removal of vegetation and soils at the initial development of the climbing site (Nuzzo 1995; Attarian and Keith 2008). In some climbing areas, scraping of fungi, 
mosses, and other non-vascular plants from cracks and crevices by climbers has been noted during the initial development of a new climbing site (Connor 1990; Vanderhorst, Jeuck, and Gawler 2007; Attarian and Keith 2008). Early research suggested that climbing had significant deleterious effects on vascular plant densities and species richness (Nuzzo 1995; Kelly and Larson 1997; Camp and Knight 1998; McMillan and Larson 2002). Nuzzo (1995) studied Solidago sciaphila Steele (Cliff Goldenrod) on both climbed and unclimbed cliffs and found declines in density, size, and production of inflorescence. Camp and Knight (1998) and McMillan and Larson (2002) later noted a decline in overall plant density and richness in climbed areas as compared to unclimbed areas. Although not statistically significant, declines in bryophyte cover and richness have also been observed at climbed areas, most notably at the talus base (Farris 1998; McMillan and Larson 2002). Studlar (1980), based on trail surveys and experiments, observed great variability in resilience and regeneration, indicating recreational use may in fact "select" for certain species present in impacted areas. Studies of the impacts of climbing on lichen communities have produced conflicting results. One study found significant declines in lichen cover and frequency associated with climbing (Nuzzo 1996) while others have noted no detectable difference between climbed and unclimbed sites (McMillan and Larson 2002), or an increase in lichen cover and frequency (Farris 1998). Many studies suggest that habitat and inter-/intra-species response to trampling and other disturbance may influence the way in which species are affected by climbing or other recreational use (Studlar 1980; Nuzzo 1995; Nuzzo 1996; Kuntz and Larson 2006b).

Despite the significant contributions from earlier works, recent studies that have utilized new methods to capture contemporary trends in climbing have produced differing results (Schuster, Thompson, and Hammit 2001; Walker et al. 2004; Kuntz and Larson 2006b; Kuntz and Larson 2006a). Many early studies do not account for structural or microsite characteristics when comparing climbed and unclimbed areas. Furthermore, many researchers do not differentiate the level of difficulty, popularity (e.g., use intensity) or style of climb (e.g., sport, traditional, top-rope) that represent the current trajectory of the sport and may result in differential impacts (Camp and Knight 1998; Schuster, Thompson, and Hammit 2001; Kuntz and Larson 2006b). Kuntz and Larson (2006a) found that when microsite characteristics were not accounted for, their results were consistent with the majority of prior research. However when investigating the influences of microtopography and climbing disturbance, the differences in cliff biota were not associated with climbing but rather to cliff faces with microsite characteristics that support less vegetation that are preferentially selected by sport climbers. These results support Farris' (1998) hypothesis, that differences in cliff biota between unclimbed and climbed cliffs are a product of climbers actively avoiding heavily vegetated cliffs. Furthermore, Walker et al. (2004) studied roofs and overhanging cliffs that advanced climbers often seek out, finding no change in plant density and richness between climbed and unclimbed sites. These results are likely an artifact of the low light levels and absence of direct precipitation under steep rock features, but highlight the importance of cliff angle and variability in vegetation. Walker et al. (2004) were unable to determine whether there is a significant effect of rock climbing on cliff vegetation, going on to suggest that the effects of climbing are likely site-specific, since the vegetation and the amount of climbing traffic are site-specific as well. The relative lack of scientific literature and conflicting results have led to debate between user groups, conservationists, and land managers, all requesting more research (Baker 1999; Jodice, Pyke, and Davidson 1999; Krajick 1999; Young 1999).

\section{New River Gorge National River}

Located on the Allegheny Plateau in southern West Virginia, the New River Gorge National River (NERI), administered by the National Park Service, is approximately 29,202 ha, containing $85 \mathrm{~km}$ of 
river. Park boundaries extend into Summers, Fayette, and Raleigh counties. The NPS owns 73\% $(20,828 \mathrm{ha})$ of the protected lands, while private landowners manage the remaining area zoned within the boundary (Mahan 2004). Within its boundaries, the park contains diverse resources including the river habitats (tributaries, shores, floodplains), gorge slopes, cliffs, plateau, and ridges. The change in elevation between the park's northern and southern boundaries is approximately $756 \mathrm{~m}$. In the northernmost extent of the gorge, the high gradient leads to nearly continuous rapids (Vanderhorst, Jeuck, and Gawler 2007).

Prior to its inception as a national river, the New River Gorge was extensively exploited for its geologic and timber resources. The first coal mine was opened in 1873 following the completion of the Chesapeake and Ohio (C\&O) Railroad. By 1900, the area supported over 8,000 coal employees and 1,800 associated manufacturing jobs (Unrau 1996). The commercial timber industry also began around 1885 and harvested forests surrounding the mines by the early 1900s (Brooks 1910). Forest fires, many associated with mining, have been recorded which likely maintained disturbance-dependent rimrock pine forests along the Endless Wall cliff throughout the 1900s (Maxwell and Hicks 2007). It is likely that mining, logging, and fires have left legacy impacts on cliff ecosystems (National Park Service 2010). Mining continued until the 1960s, when the gorge gained notoriety for its recreational potential (Thompson 1997). In 1978, the New River Gorge National River (NERI) was established by the National Park Service for "the purpose of conserving and interpreting outstanding natural, scenic, and historic values and objects in and around the New River Gorge and preserving as a free-flowing stream an important segment of the New River in West Virginia for the benefit and enjoyment of present and future generations" (Public Law 95$625)$.

\section{Botanic Overview}

Several studies have documented the occurrence of hundreds of plants native and rare to West Virginia in NERI. One of the early botanists of the New River Gorge was Lawrence W. Nuttall (1890s), a coal mine operator who collected approximately 1000 species of flowering plants. Others include Weldon W. Boone (1930s), who collected nearly two dozen new records, and Violet S. Phillips (1960s), whose PhD dissertation, The Botany of the New River Valley Between Glen Lyn, Virginia and Gauley Bridge represent some of the earliest examples of floristic inventories conducted in the New River Gorge (Phillips 1969; Grafton and McGraw 1982). Later, Grafton and McGraw (1982) compiled a brief pamphlet from floral surveys that described plant communities along the river and cold coves of tributary canyons. Several studies conducted by the West Virginia Natural Heritage Program (WVNHP) surveyed sites in the park for rare plant species (Rouse and McDonald 1986; McDonald 1989; McDonald and Harman 1989; McDonald and Trianosky 1995; McDonald 1998; McDonald 2000a; McDonald 2000b). Suiter and Evans (1999) also documented vascular flora and rare species of the gorge, recording over 1,300 taxa including 27 taxa with some special designation of rarity in West Virginia. The only known survey for lichens and bryophytes was conducted by Weaks et al. (1997), although some studies such as Vanderhorst (2001) and Vanderhorst et al. (2007) recorded several macrolichen species.

Fortney et al. (1994) were among the first to do reconnaissance of vegetation around the cliffs of the Endless Wall. Vanderhorst (2001) and Vanderhorst et al. (2007) surveyed and mapped plant communities of the NERI. Approximately $83 \%$ of the park area is mapped as upland forests and woodlands, where $83 \%$ of this the mapped area is classified as three deciduous forest community types: 1) Oak - Hickory Forest (Quercus prinus L. - (Quercus rubra L.) - Carya spp. Nutt./ Oxydendrum arboreum (L.) DC. - Cornus florida L. Forest; USNVC EL code: CEGL007267), 2) Oak - Hickory - Sugar Maple Forest (Quercus prinus - Carya ovata (Mill.) K. Koch - Quercus rubra / Acer saccharum Marsh. Forest; USNVC EL code: CEGL007268), and 3) Sugar Maple - Yellow Buckeye - American basswood 
Forest (Liriodendron tulipifera L. - Tilia americana L. var. heterophylla (Vent.) Loudon - Aesculus flava Aiton - Acer saccharum/(Magnolia tripetala (L.) L.) Forest; USNVC EL code: CEGL005222). Vanderhorst et al. (2007) suggested that "stands of these communities are among the largest protected occurrences of these associations in West Virginia and perhaps the world." Mapped cliffs occupy only $0.024 \%$ of the park area. Spanning all vegetation communities of the NERI, Vanderhorst (2003) used GIS analysis to identify large ( $>40.46 \mathrm{ha}$ ), unfragmented forest blocks. They determined that about $91 \%$ of area preserved within the park boundary is contained within blocks greater than 40.46 ha and about $45 \%$ is within blocks greater than 202 ha.

Although important to the conservation and protection of the New River, the cliffs of the NERI have seen relatively little attention from science or management (Mahan 2004; Vanderhorst, Jeuck, and Gawler 2007). Vanderhorst et al. (2007) state that sandstone cliff tops support small patches and linear zones of Virginia Pine (Pinus virginiana Mill.) and Pitch Pine (Pinus rigida Mill.) forests on southerly aspects, and Eastern Hemlock - Chestnut Oak/Catawba Rhododendron forests (Tsuga canadensis-Quercus prinus/Rhododendron catawbiense Michx.) on northerly aspects. Maxwell and Hicks (2007) studied the causal factors in establishment and extent of unique rimrock (cliff dwelling) pine communities found on the Endless Wall, noting that they are most common on the southern and southwestern aspects of the northern section of the Gorge, occurring on shallow xeric soils. Mahan (2004) notes the significance of the cliffs to the park, suggesting they support specific and sensitive species of plants (e.g., cliff ferns, old-growth cedars), reptiles (e.g., coal skink), amphibians (e.g., green salamander), and invertebrates (e.g., terrestrial gastropods). Regardless, Mahan's (2004; pg 51) report titled, A Natural Resource Assessment for New River Gorge National River, noted that "the cliff habitats at NERI are the least studied and understood community type in the park" going on to recommend that "a detailed inventory of flora and fauna using cliffs at NERI should be conducted."

\section{Recreation}

The park is currently a popular destination for a diverse group of users including whitewater rafting, hiking, fishing, hunting, biking, and rock climbing (Mahan 2004). Since 1984, annual visitation to NERI has quadrupled from 230,000 to over 1.1 million (National Park Service 2005; National Park Service 2006). Due to an increase in adventure based tourism, multiple climbing, rafting, and outdoor-based guide services operate in and around the New River Gorge. As a reflection of increased popularity, the demand for permits to conduct rock climbing instruction and guiding services has steadily increased since 1995 (National Park Service 2005).

The first recorded rock climbs in the New River Gorge were established in 1975, relatively recently compared to other climbing destinations in the eastern United States (Thompson 1997; Williams 2010). Thompson (1997) describes the climbing in the New River Gorge as a "one-pitch paradise," referring to the height of the cliffs $(<50 \mathrm{~m})$ and high concentration of climbing routes. Climbs represent an impressive range in difficulty (e.g., 5.1-5.14+; Yosemite Decimal System [YDS]), style (e.g., traditional, sport, top-rope, bouldering), and cliff features used (e.g., crack, roof, low-angle slab, slanty overhangs) are evenly distributed throughout the upper section of the gorge, north of Keeneys Creek (Graydon and Hanson 1997; Williams 2010). It is estimated that $90 \%$ or more of the established climbing routes are on public lands (National Park Service 2005). Williams (2010) documents over 1,700 rock climbs in the New River Gorge (Table 1.1) representing the breadth of climb styles and difficulties of modern rock climbing (Figures 1.1 to 1.3). Furthermore, an additional 1,000 climbing routes are found on cliffs outside of the park (e.g., Summersville Lake, Meadows, Gauley River). Due to the abundance, variety, and accessibility of climbs, the cliffs in and around the New River Gorge are considered a popular destination for climbing in the eastern United States. 


\begin{tabular}{lcccccc}
\hline \hline & $\begin{array}{c}\text { No. cliff } \\
\text { *sectors }\end{array}$ & No. climbs & $\begin{array}{c}\text { Climbs per sector } \\
(\overline{\mathbf{x}})\end{array}$ & Approach time $(\overline{\mathbf{x}})$ & $\begin{array}{c}\text { No. sport } \\
\text { climbs }\end{array}$ & $\begin{array}{c}\text { No. traditional } \\
\text { climbs }\end{array}$ \\
\hline \hline All cliffs & 89 & 1734 & $19.5 \pm 9.3$ & $16.1 \pm 8.7$ & 694 & 1040 \\
Gorge east & 72 & 1507 & $20.9 \pm 9.3$ & $14.2 \pm 5.8$ & 565 & 972 \\
Gorge west & 17 & 227 & $13.4 \pm 6.1$ & $24.1 \pm 13.4$ & 129 & 98 \\
\hline
\end{tabular}

Table 1.1: Descriptive statistics of rock climb in the New River Gorge, derived from Williams (2010). *Sector is defined as a cliff section as described in the climbing guidebook.

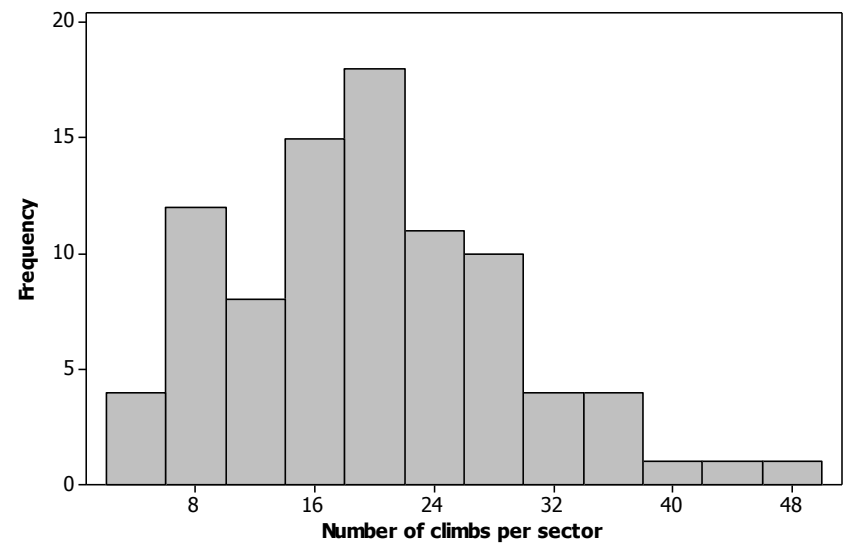

Figure 1.1: Frequency of rock climbs established in a cliff sector, as described by Williams (2010)
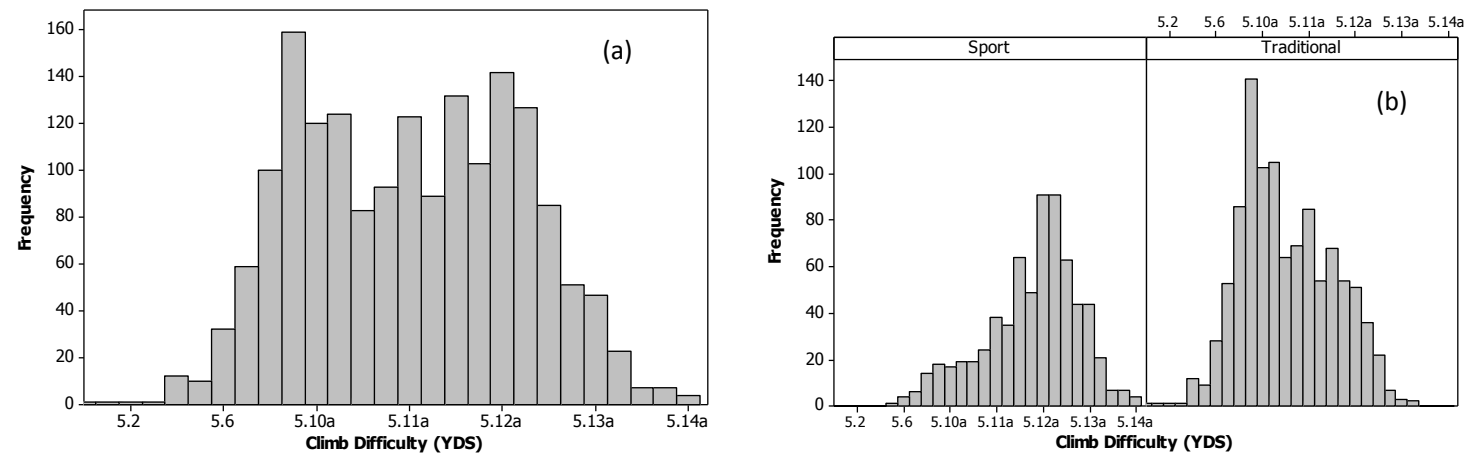

Figure 1.2a-b: Frequency of rock climbs a) climb difficulty (YDS) and b) climb difficulty and climb style (Graydon \& Hanson, 1997; Williams 2010) 

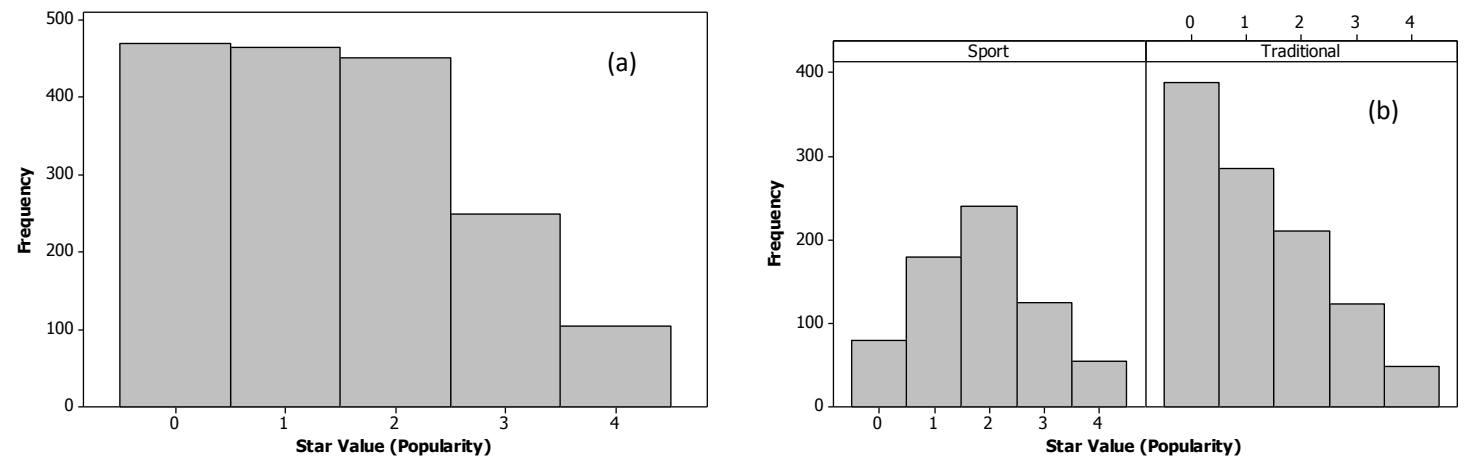

Figure 1.3a-b: Frequency of rock climbs a) star value (e.g., popularity) and b) star value and climb style (Graydon \& Hanson, 1997; Williams 2010)

\section{Study Area: Upper Gorge}

Geologically, the northern section of NERI (between Keeneys Creek and the Hawks Nest Dam) is composed of sandstone dominated by the Pottsville Group, containing the coal-bearing New River and Pocahontas formations (Englund et al. 1977; Englund, Johnson, and Amdt 1982). The canyon, which is up to $378 \mathrm{~m}$ deep, is lined with an estimated $32 \mathrm{~km}$ of exposed rock cliff (Mahan 2004). The major cliff-forming rock features are composed of the Upper and Lower Nuttall, Guyandot, Upper and Lower Raleigh, and Pineville Sandstones (Figure 1.4; Englund, King, Lesure, \& Perry, 1977; Remo, 1999; Korus, 2002). Vertical fractures and horizontal bedding have formed roof features that typify the cliffs of the New River Gorge, some up to $15 \mathrm{~m}$ (Thompson 1997). The quartz-rich upper Nuttall Sandstone lines the rim of the gorge and is highly resistant to weathering. This rock type appears to be preferred by climbers and contains most of the rock climbing routes in the gorge (K. H. Olcott 2011a).

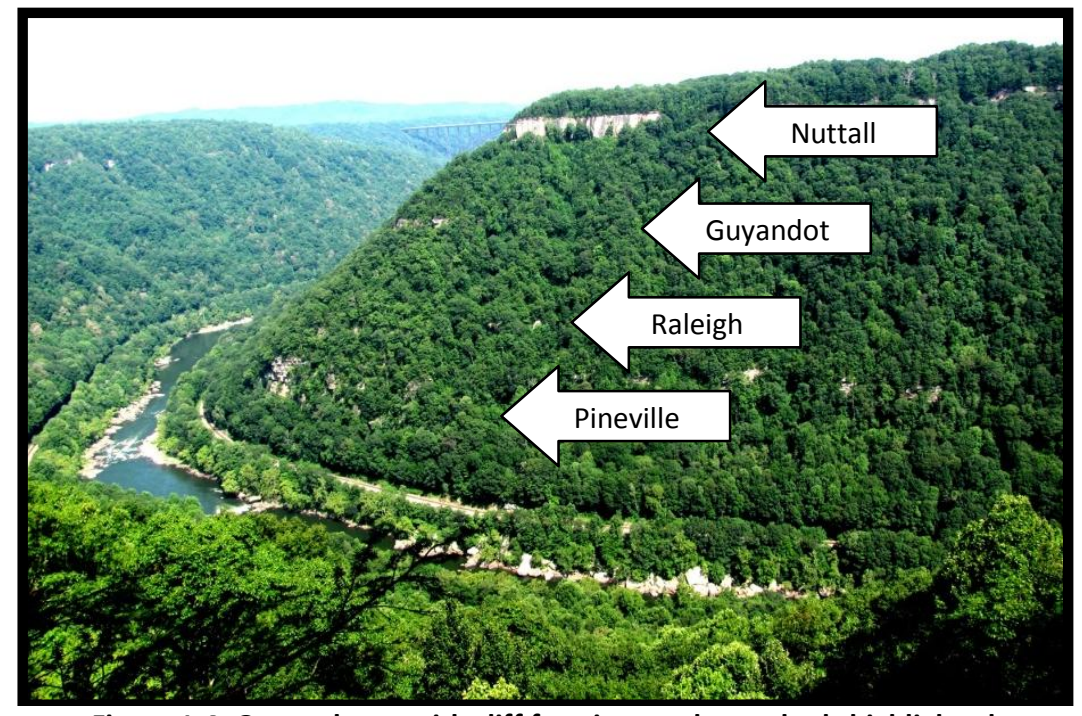

Figure 1.4: Gorge slopes with cliff forming sandstone beds highlighted

The major soil association of the NERI is the Steep Rockland-Dekalb-Gilpin Association (Mahan 2004) with characteristics of the Matewan Series on cliff tops and the Handshoe Series at the base (National Park Service 2005). Soil surveys conducted in 2001 by the USDA Natural Resources 
Conservation Service found that soils around cliffs are primarily coarse and shallow with distinct differences between the soils on the north-facing and south-facing slopes (Jenkins 2001). In general, soils on south-facing slopes were shallower (thinner 0 and A horizons) and more xeric compared to their north-facing counterparts. Jenkins (2001) noted more bare spots on southfacing slopes, suggesting that soils of these slopes are less resilient (perhaps reflecting vegetation dynamics) than those on north-facing slopes.

River sinuosity and outcrop orientation lead to a high variability in aspect for gorge slopes and cliffs, which in turn influences forest composition and botanic diversity. According to Vanderhorst et al. (2007), park vegetation is characterized by widespread upland deciduous forests (83\%), smaller areas of conifer-dominated upland forest, and small areas of specialized communities associated with cliffs, wetlands, and riparian zones. Using vegetation classification maps using U.S. National Vegetation Classification standards (USNVC) Vanderhorst et al. (2007) found that NERI consists of 41 community types (39 USNVCS associations) including 16 upland forest and woodland types, 15 riparian types, five headwater wetland types, three cultural types, and two cliff types. Important trees in the park include Aesculus flava Aiton (yellow buckeye), Liriodendron tulipifera (tuliptree), Nyssa sylvatica Marsh. (blackgum), Tilia americana L. (American basswood), Tsuga canadensis (eastern hemlock), and species of Acer sp. (maples), Betula sp. (birches), Carya sp. (hickories), Fraxinus sp. (ashes), Magnolia sp. (magnolias), Pinus sp. (pines), and Quercus sp. (oaks). Sparsely vegetated rock faces and cliffs include narrow bands of pine forest and woodland along their tops. Even though a large part of the park is characterized by upland deciduous forests, Vanderhorst et al. (2007) and Mahan (2004) maintain that much of the ecological and species diversity of the park is represented by the small areas of cliff, riparian, and wetland communities.

The climate of the park is characterized by a humid continental type marked by seasonal temperature changes and uniform precipitation throughout the year. Mean monthly temperature normals at the nearby Beckley Airport (elevation $763 \mathrm{~m}$ ) range from $-0.8^{\circ} \mathrm{C}$ in January to $21.5^{\circ} \mathrm{C}$ in July. Normal total annual precipitation at the Beckley airport is $105.74 \mathrm{~cm}$ and monthly precipitation totals range from $6.7 \mathrm{~cm}$ in October to $12.1 \mathrm{~cm}$ in July (Mahan 2004; Vanderhorst, Jeuck, and Gawler 2007; National Climatic Data Center 2010). 


\section{CHAPTER TWO}

\section{The Effects of Rock Climbing on Cliff Ecosystems in the New River Gorge, WV}

\section{Introduction}

Cliff environments are found world-wide yet are among the least understood ecosystems globally (Larson, Matthes, and Kelly 2000). Cliffs have long been viewed simply as transitional breaks on landscapes rather than distinct habitats with unique environmental conditions (Graham and Knight 2004). Most scientific studies of cliffs have focused on geological, morphological, or hydrological characteristics, while cliff ecosystems have largely been overlooked by biologists and ecologists (Larson, Matthes, and Kelly 2000). As a result, comparatively little is known about biological diversity and community ecology of these environments. However, modern remote sensing technologies such as LiDAR now allow cliffs to be accurately identified and mapped (Adams and Chandler 2003; Zimmer et al. 2012), yielding new opportunities for defining biotic communities and understanding the role of cliff ecosystems in a landscape. At the same time, increasing levels of recreation on cliffs has led to conflicts between managers, users, and conservationists (Krajick 1999; Baker 1999; Jodice, Pyke, and Davidson 1999; Young 1999; Attarian 1999). Methods for measuring biotic diversity and anthropogenic impacts on cliffs will be increasingly important for management agencies in the future.

Recently, a surge of research has focused on cliffs as discrete ecosystems, demonstrating that despite spatial fragmentation, cliffs support highly specialized and distinct biota (Larson and Kelly 1991; Camp and Knight 1998; Larson, Matthes, and Kelly 2000; Larson et al. 2000; Graham and Knight 2004; Walker et al. 2004; de Lange and Norton 2004; Kuntz and Larson 2006a). Regardless of geographic setting, cliffs regularly sustain relict, undisturbed, and often ancient ecosystems (Larson, Matthes, and Kelly 2000; Larson et al. 2000), including rare flora and fauna (Larson, Matthes, and Kelly 2000; de Lange and Norton 2004). Floristic studies indicate that many plants are well adapted to survive on seemingly harsh cliff environments as their primary habitat (Oosting and Anderson 1937, 1939; Larson and Kelly 1991; Cox and Larson 1993; Kelly, Cook, and Larson 1994; Larson, Matthes, and Kelly 2000; Thiel and Spribille 2007). Furthermore, ancient human populations have used cliffs as dwellings or sacred grounds (Douglass 1929) and many are highlighted in national parks as tourist destinations. Ecologically and socially significant, management of cliffs ecosystems has been largely overlooked and with little standardization of policies (National Park Service 2002; Squire 2003; National Park Service 2005; Jefferson County Open Space 2006; National Park Service 2007; Attarian and Keith 2008; White Mountains National Forest 2008).

Cliff faces are highly heterogeneous, composed of macro-topographic (e.g., large ledges, dihedrals, roofs, and cracks) and micro-topographic (e.g., edges, crevices, overlaps) features. These heterogeneous surfaces are the basis for cliff ecosystems as they provide crucial habitat and rooting space for many vascular and nonvascular plants (Oosting and Anderson 1937; Larson, Matthes, and Kelly 2000; Kuntz and Larson 2006a). Due to physical heterogeneity, highly complex and dissimilar 
ecosystems may form adjacent to one another. For example, heat-resistant and desiccation-tolerant organisms such as lichens may exist on sheer rock walls bordering features such as ledges and cracks which accumulate soils and harbor vascular plants common to wetland environments.

As in other ecosystems, variability in the physical environment influences the development of cliff ecosystems. Orientation, aspect, solar radiation, moisture, temperature, gravity, and wind are all controlling processes that influence cliff environments (Larson, Matthes, and Kelly 2000). Initially, ecologists argued that succession was an important processes in controlling cliff vegetation (Oosting and Anderson 1937; Oosting and Anderson 1939; Keever, Oosting, and Anderson 1951), but more recent works emphasize the role of physical features in controlling diversity and composition of plant communities on cliffs (Bostick 1971; Smiley and George 1974; Ursic, Kenkel, and Larson 1997). Kuntz and Larson (2006a) evaluated the role of physical features in the organization of cliff-face vegetation communities by examining large (geographic), local (macrotopographic), and fine scale (microtopographic) rock features. Their results suggest that fine scale microtopographic features are important drivers in the establishment of cliff vegetation, leading to isolated and distinct micro-communities.

Unlike most terrestrial environments, cliff habitats are affected by relatively few natural disturbance agents (Larson, Matthes, and Kelly 2000). The force of gravity, falling debris (e.g., ice, rock, organic matter), and wind are some of the most common natural processes that influence the development of cliff biota. Undoubtedly, one of the greatest contemporary disturbance agents currently affecting cliff-dwelling plant communities are recreational activities such as hiking at cliff bases and tops and technical rock climbing on cliff faces (Kelly and Larson 1997; Farris 1998; Larson, Matthes, and Kelly 2000; McMillan and Larson 2002). Due to the recent popularity of rock climbing globally, there is a growing concern that cliff biodiversity in more popular climbing areas has been, and continues to be, degraded by impacts from climbing (Nuzzo 1995; Kelly and Larson 1997; McMillan and Larson 2002; Squire 2003; Rusterholz, Muller, and Baur 2004; National Park Service 2005; Thiel and Spribille 2007; Attarian and Keith 2008). The most common impacts from climbing occur from trampling at cliff bases and cliff tops, and removal of vegetation and soils on cliff faces at the initial development of the climbing route (Nuzzo 1995; Attarian and Keith 2008). Despite concerns for these environments, comparatively few studies address these disturbances. This has led to debate between user groups and land managers, both requesting more research (Jodice, Pyke, and Davidson 1999; Krajick 1999; Baker 1999; Young 1999; Jones and Hollenhorst 2002; National Park Service 2005; Murdock 2010)

Many initial studies indicate that climbing causes deleterious effects on cliff environments (Nuzzo 1995; Kelly and Larson 1997; Camp and Knight 1998; Farris 1998; Larson, Matthes, and Kelly 2000; McMillan and Larson 2002). Because of the recent development of the field of cliff ecology, a lack of standardization across study designs and methods has led to varying and inconsistent results among studies. For example, Nuzzo (1996) found significant declines in lichen cover and frequency on cliff faces associated with climbing, whereas McMillan and Larson (2002) note no detectable difference, and Farris (1998) report slight increases. Recent studies that capture differential effects of climb difficulty and style produce more consistent results (Walker et al. 2004; Kuntz and Larson 2006a; Kuntz and Larson 2006b). When Kuntz and Larson (2006b) accounted for cliff face microsite characteristics, the differences in plant diversity, abundance, and community composition were not associated with climbing disturbance but rather the variability in cliff face microtopography. Walker et al. (2004) included roofs and overhanging cliffs that advanced climbers often seek out that other researchers avoided (Kelly and Larson 1997; McMillan and Larson 2002), and found no change in plant density and richness between climbed and unclimbed sites. Walker's results may be an artifact of the low light levels and lack of precipitation under 
steep rock features, but highlight the potential interactions between climb popularity, cliff angle, and topographic features. Furthermore, many researchers view disturbance from climbing as either present or absent (Nuzzo 1995; Kelly and Larson 1997; Camp and Knight 1998; Farris 1998; McMillan and Larson 2002; Rusterholz, Muller, and Baur 2004) rather than a discrete or continuous process. While climb popularity has been addressed in some studies (Nuzzo 1995; Farris 1998; McMillan and Larson 2002; Thiel and Spribille 2007), only one has successfully incorporated the frequency or intensity of use to understand variability in disturbance (Camp and Knight 1998). Camp and Knight use rock climb density and quality ratings from the local climbing guidebook to categorize use intensity at the cliff level using three classes: "no use," "moderate use," and "heavy use." Their results showed significant declines in species richness and frequency among use classes, but because the authors used cliff sector as their unit of analysis, they were not able to make inferences at the scale of the climb. This is a critical limitation since use varies at the climb, not the cliff level. Sound, reproducible science on the effects of climbing on cliff communities is clearly needed if these systems are to be understood and protected.

The objectives of this study are to include gradients of use intensity and climb difficulty as well as climb style to understand the effects of climbing on cliff ecosystems. We investigate impacts to species richness, soil depth, and length of hardened zone at three different cliff positions: cliff top, cliff face, and cliff base. We hypothesize:

$\mathrm{H}_{1}$ : Species richness on cliff faces is reduced as climb difficulty increases, but impacts are moderated by use (Figure 2.1).

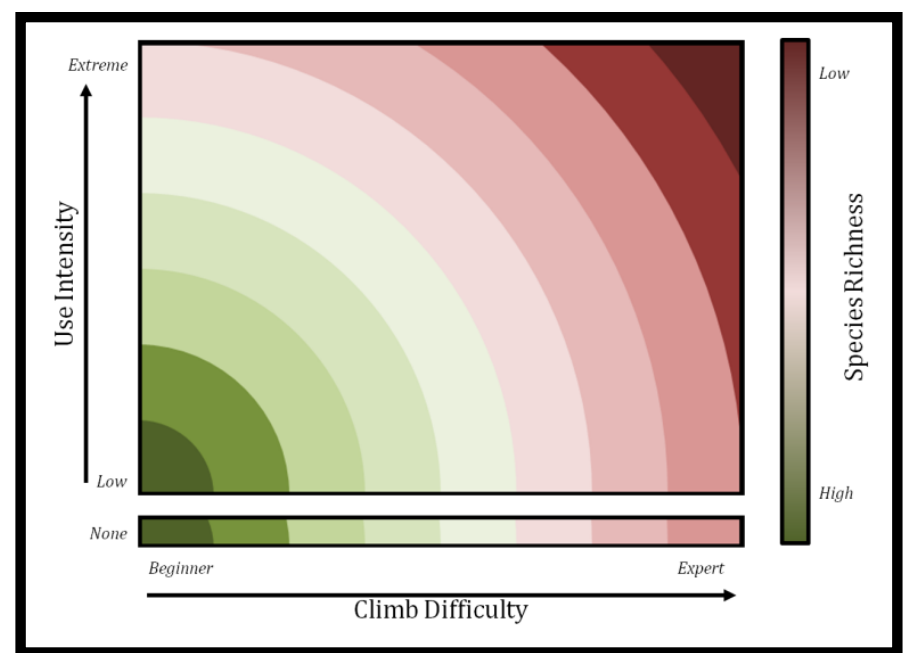

Figure 2.1: Figure visually describing Hypothesis One 
$\mathrm{H}_{2}$ : Impacts to cliff top and base increase with use, but are not influenced by climb difficulty (Figure 2.2).

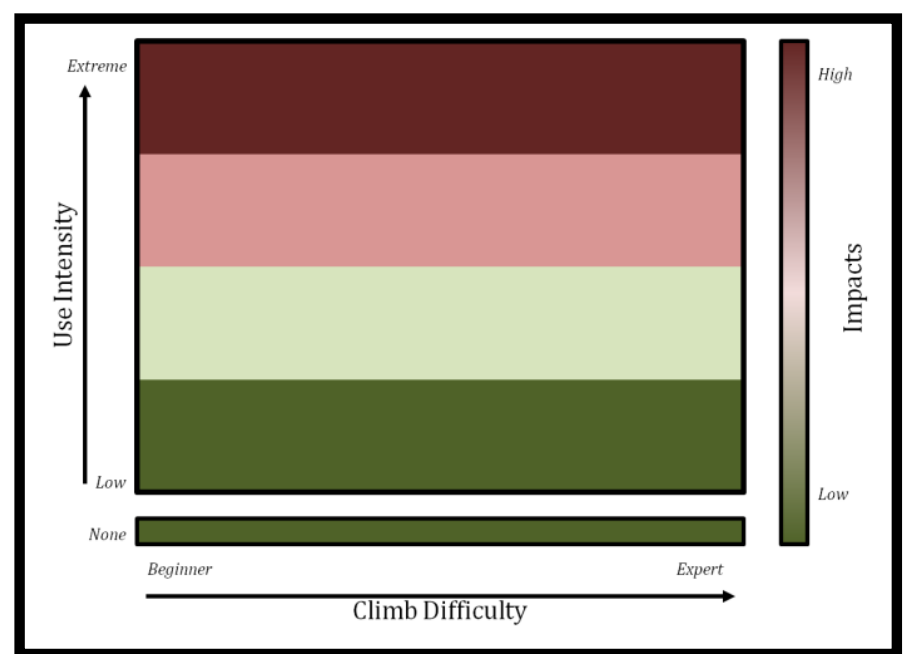

Figure 2.2: Figure visually describing Hypothesis Two

$\mathrm{H}_{3}$ : Impacts at cliff top vary by climb style where traditional style climbs sustain greatest impacts, but climb style does not affect cliff face or base (Figure 2.3).

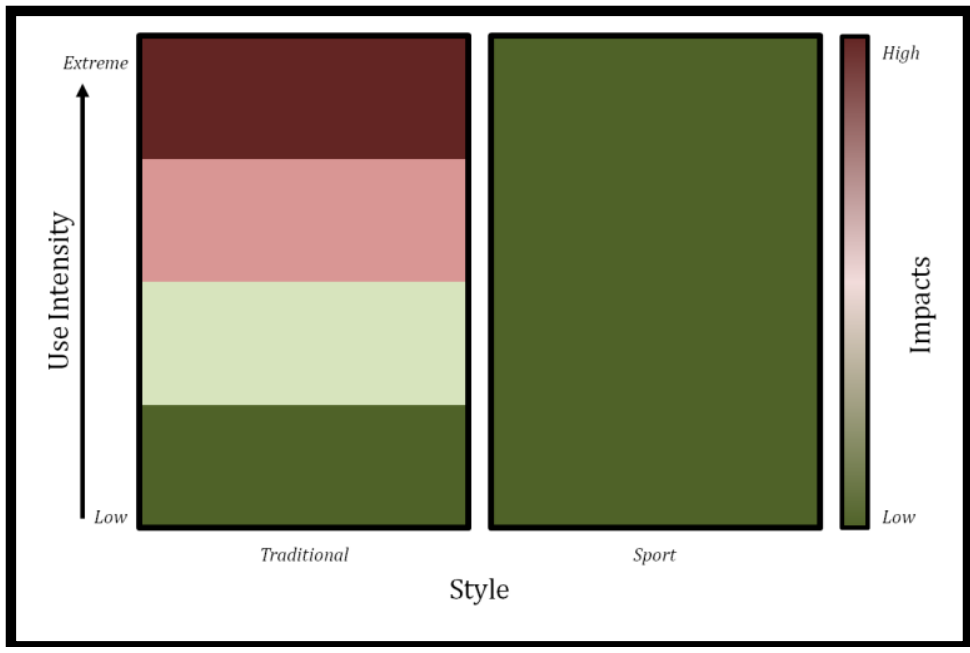

Figure 2.3: Figure visually describing Hypothesis Three

\section{Methods}

\section{Study site}

The New River Gorge National River (NERI), administered by the National Park Service, is located on the Allegheny Plateau in south-central West Virginia, USA. The park is approximately 29,200 ha and contains diverse natural resources including $85 \mathrm{~km}$ of river-way (tributaries, shores, floodplains), steep gorge slopes, cliffs, and plateaus (Figure 2.4). River sinuosity and outcrop 
orientation create variability in gorge slopes and cliff aspects which influence forest composition, botanic diversity, slope stability, and cliff structure (Vanderhorst 2001; Mahan 2004; Vanderhorst, Jeuck, and Gawler 2007). Geologically, the northern section of NERI, which for this research includes park area adjacent to Fayetteville and Lansing municipalities and encompasses an approximate $14 \mathrm{~km}$ linear section between Keeneys Creek to the Hawks Nest Dam (mean elevation $535 \pm 48 \mathrm{~m}$ ). This area is composed of sandstone dominated by the Pottsville Group, containing the coal-bearing New River Formation (Englund et al. 1977; Englund, Johnson, and Amdt 1982). Canyon slopes are lined with approximately $97 \mathrm{~km}$ of exposed cliff comprised of four major cliff forming sandstone units including the Nuttall, Guyandot, Raleigh, and Pineville Sandstones as well as several lesser member sandstone units (Englund et al., 1977; Remo, 1999; Chapter Three). The cliffs in this study are composed of the highly resistant, quartz-rich upper and lower Nuttall Sandstones which extend for $38 \mathrm{~km}$ along the rim of the gorge.

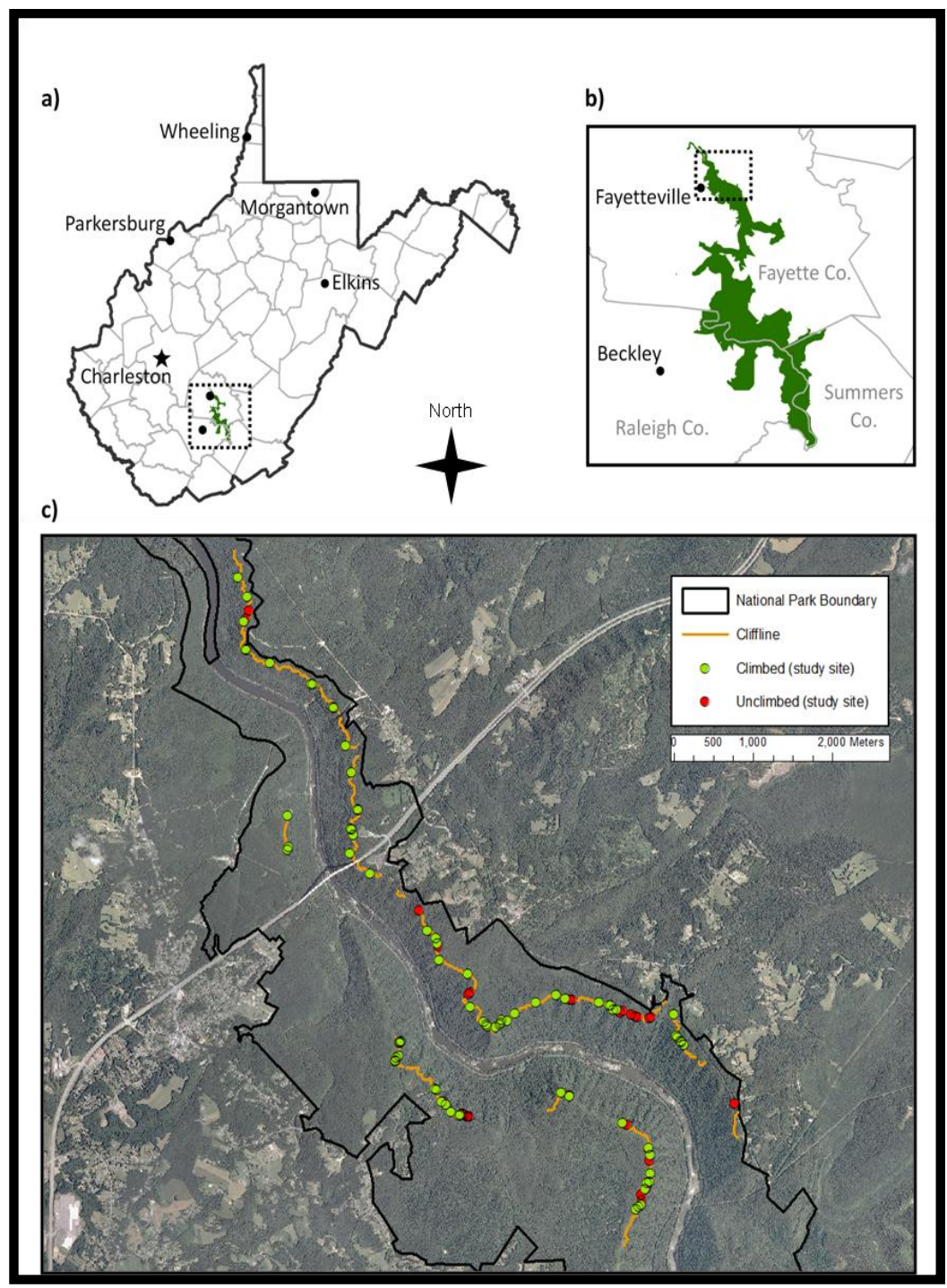

Figure 2.4: The study area, (a) located in southern West Virginia in (b) the New River Gorge National River. (c) All study sites were located in the northern section of the gorge near Fayetteville, WV on Nuttall Sandstone cliffs. 
Nuttall Sandstone cliffs can reach up to $50 \mathrm{~m}$ in height. Vertical fractures and horizontal bedding characteristic of this group form overhanging roof features that typify the cliffs of the New River Gorge. The Nuttall Sandstone is preferred by rock climbers over other cliff forming features present in NERI (K. H. Olcott 2011a) and contains nearly all documented climbing areas in the gorge. These cliffs are representative of the breadth of climbing difficulty standards (Yosemite Decimal System [YDS]), styles (e.g., traditional [removable protection], sport [fixed bolt protection]), and cliff features used (e.g., crack, roof, low-angle slab, slanty overhangs) in modern rock climbing (Graydon and Hanson 1997; Williams 2010). The first recorded rock climbs in NERI were established in 1975, but there are at present over 1,700 climbing routes documented on over 80 described cliff sections, or "sectors". An additional 1,000 climbs are located on cliffs outside of the park (e.g., Summersville Lake, Meadow, and Gauley River), creating a regional and national destination for rock climbing and associated activities (Williams 2010).

The National Park Service established NERI as a park unit in 1978 to protect and conserve the New River Gorge area. Prior to park establishment, direct impacts from human activities including coal mining, logging, burning, transportation, and residential developments influenced almost all areas of the New River Gorge region (Unrau 1996). The Park Service has long recognized the use of cliffs for climbing in NERI. One of the early management practices in 1996 restricted the use of power drills for installation of permanent climbing anchors, which curtailed anchor replacement and reduced new sport route development. In 2005 a draft climbing management plan was enacted (National Park Service 2005) in response to obvious impacts to cliff resources (such as soils, plant communities, wildlife species) and to complaints (due to conflicts among user groups). Despite these concerns and actions, there have been few scientific studies of the cliffs of NERI (Mahan 2004; National Park Service 2005; Vanderhorst, Jeuck, and Gawler 2007).

Park vegetation is characterized by widespread upland deciduous forests (83\%), smaller areas of conifer-dominated upland forest, and small sections of specialized communities associated with cliffs, wetlands, and riparian zones (Vanderhorst, Jeuck, and Gawler 2007). Sandstone cliffs act as natural breaks where cliff tops and bases support contrasting forest communities. Along southerly aspects, cliff tops support small, linear patches of woodland classified as Pinus virginiana Mill. and Pinus rigida Mill. forests, while bases are dominated by Quercus L.-Carya Nutt. /Acer saccharum Marsh. forests (USNVC standards). Conversely, northerly cliff tops are dominated by Tsuga canadensis (L.) Carrière-Quercus prinus L./Rhododendron catawbiense Michx. forest and bases by Liriodendron tulipifera L.-Tilia americana var. heterophylla (Vent.) Loudon-Aesculus flava Aiton-Acer saccharum forest (Vanderhorst, Jeuck, and Gawler 2007; Maxwell and Hicks 2007). Cliff faces have been classified into two associations by Vanderhorst et al. (2007): 1) Umbilicaria mammulata (Ach.) Tuck. Nonvascular Vegetation and 2) Appalachian-Alleghenian Sandstone Dry Cliff Sparse Vegetation. Jenkins (2001) reported variability in soils by aspect where southerly slopes sustain substantially thinner soils, indicating a susceptibility to use. Mahan (2004) noted the significance of the cliffs and associated natural resources: specific and sensitive species of plants, reptiles, amphibians, and invertebrates. Even though a large part of the park is characterized by upland deciduous forests, Vanderhorst et al. (2007) and Mahan (2004) maintain that much of the ecological and species diversity of the park is represented by the small areas of cliff, riparian, and wetland communities.

The climate of the park is characterized by a humid continental type marked by seasonal temperature changes and uniform precipitation throughout the year. Mean monthly temperature normals at the nearby Beckley Airport (elevation $763 \mathrm{~m}$ ) range from $-0.8^{\circ} \mathrm{C}$ in January to $21.5^{\circ} \mathrm{C}$ in July. Average total annual precipitation at the Beckley airport is $105.74 \mathrm{~cm}$ and monthly 
precipitation totals range from $6.70 \mathrm{~cm}$ in October to $12.14 \mathrm{~cm}$ in July (Mahan 2004; Vanderhorst, Jeuck, and Gawler 2007; National Climatic Data Center 2010)

\section{Sampling Design}

We sampled a total of 112 research sites throughout the northern extent of NERI including: 80 experimental sites located on previously established rock climbs as described by the local climbing guidebook (hereby referred to a climbed), and 32 control sites (hereby referred to a unclimbed) deemed suitable for and characteristic of rock climbing following methods described by McMillan \& Larson (2002) and verified by the first author of this paper and a local climber (Table 2.1). We randomly selected all sites from Nuttall Sandstone cliffs and met criteria described by earlier studies such that they were: a) greater than $12 \mathrm{~m}$ in height; b) without excessive amounts of loose rock; c) absent of annual water seeps; and d) had an overall cliff angle $>60^{\circ}$ (Larson, Matthes, and Kelly 2000; Kuntz and Larson 2006b; Kuntz and Larson 2006a).

\begin{tabular}{|c|c|c|c|c|c|c|}
\hline \multirow[b]{2}{*}{ Difficulty } & \multicolumn{4}{|c|}{ Climbed $(\mathrm{N}=80$ out of 1,737$)$} & \multirow{2}{*}{$\begin{array}{c}\text { Unclimbed } \\
(\mathrm{N}=32) \\
\text { No Use }\end{array}$} & \multirow[t]{2}{*}{ Total } \\
\hline & Low Use & Medium Use & High Use & Extreme Use & & \\
\hline \multicolumn{7}{|c|}{ Gorge East } \\
\hline $\begin{array}{l}\text { Beginner } \\
(5.6-5.8)\end{array}$ & 3 & 3 & 3 & 3 & 4 & 18 \\
\hline $\begin{array}{l}\text { Intermediate } \\
(5.9-5.10 \mathrm{~d})\end{array}$ & 3 & 3 & 3 & 3 & 4 & 18 \\
\hline $\begin{array}{l}\text { Experienced } \\
(5.11 \mathrm{a}-5.12 \mathrm{~b})\end{array}$ & 3 & 3 & 3 & 3 & 4 & 18 \\
\hline $\begin{array}{l}\text { Expert } \\
(5.12 c-5.14)\end{array}$ & 3 & 3 & 3 & 3 & 4 & 18 \\
\hline Subtotal East & 12 & 12 & 12 & 12 & 16 & 64 \\
\hline $\begin{array}{l}\text { Beginner } \\
(5.6-5.8)\end{array}$ & 2 & 2 & 2 & 0 & 4 & 10 \\
\hline $\begin{array}{l}\text { Intermediate } \\
(5.9-5.10 \mathrm{~d})\end{array}$ & 2 & 2 & 2 & 4 & 4 & 14 \\
\hline $\begin{array}{l}\text { Experienced } \\
(5.11 \mathrm{a}-5.12 \mathrm{~b})\end{array}$ & 2 & 2 & 2 & 2 & 4 & 12 \\
\hline $\begin{array}{l}\text { Expert } \\
(5.12 c-5.14)\end{array}$ & 1 & 3 & 2 & 2 & 4 & 12 \\
\hline Subtotal West & 7 & 9 & 8 & 8 & 16 & 48 \\
\hline
\end{tabular}

We randomly selected established rock climbs from a pool of 1,737 possible sites and stratified based on climb difficulty, potential use intensity, and cliff aspect. Climbs rated 5.6 through 5.14 YDS are included in the study and grouped by four difficulty classes: "beginner" (5.6-5.8), "intermediate" (5.9-5.10d), "experienced" (5.11a-5.12b), and "expert" level (5.12c-5.14). We determined potential climb use intensity (CUI) by the time required to walk to a cliff area (T) and the popularity of the individual climb. We inferred popularity by the number of "stars" $(S)$ assigned in the climbing guidebook, where climbs are ranked from "0" to " 4 stars" by the guidebook author. The model used to calculate CUI is as follows:

$$
C U I=\log 10\left([S+1] *\left(\left[\frac{1}{T}\right] * 100\right)\right)
$$


The model quantifies the hypothesized direct relationship of climb popularity (stars) and the accessibility of the cliff (time to walk there). CUI provides a normally distributed index ranging from 0.31 to 2.22 . We classified use intensity classes by quartile, where values within the first (lowest) quartile are categorized as "low," second quartile as "moderate," third quartile as "high," and fourth quartile as "extreme" use. "No use" sites (unclimbed) were assigned CUI values of "0."

Established rock climbs in NERI are predominantly found on the eastern gorge rim which is dominated by south and west facing cliffs. To accurately capture both climbing trends and ecosystems present in NERI, we stratified our samples by gorge side in lieu of aspect. As a result, we sampled $60 \%$ of climbed sites (48) on the eastern gorge rim. We located the remaining $40 \%$ (32) of sites on the western gorge rim which is dominated by north and east facing cliffs. We did not specifically stratify sites by climb style (e.g., traditional, sport) because both groups occur in approximately equal frequency.

We randomly selected unclimbed cliff sites suitable for climbing from a pool of 231 possible locations. Similarly, we stratified these sites by estimated difficulty and cliff aspect. We estimated climb difficulty after sites were pre-inspected from the ground by the first author and a local climber, then verified our estimates using cliff structure (angle and topography) as quantitative metrics (Kuntz and Larson 2006b; Chapter Three). Unlike climbed sites, gorge side (e.g., aspect) was not weighted to stratify our samples of control sites. All potential unclimbed sites were: a) located $>30 \mathrm{~m}$ from established rock climbs; b) exhibited no visible presence of use (e.g., climbing chalk, bolts, associated gear, trails, etc); c) not described in any local climbing guidebooks (Cater 1995; Thompson 1997; Horst 2003; Williams 2010); d) occurred on cliffs > $7 \mathrm{~m}$ wide; e) and were deemed appropriate for climbing by the first author and a local climber (McMillan and Larson 2002). We did not consider variables such as cliff length or distance from human facilities when selecting unclimbed sites (Camp and Knight 1998).

To examine disturbance on multiple cliff sections, we placed study plots on three positions: cliff base, cliff face, and cliff top (Figure 2.5). At the cliff top, where slope was less than $50 \%$ or a natural anchor staging area could be determined, we positioned a $1 \times 3 \mathrm{~m}$ belt transect extending away from the cliff edge. Similarly, a 1 x $5 \mathrm{~m}$ transect was placed at the cliff base with three nested $1 \mathrm{~m}^{2}$ quadrats spaced at $1 \mathrm{~m}$ intervals. Transect dimensions were selected after our preliminary field reconnaissance indicated that areas of human use were commonly most concentrated within $3 \mathrm{~m}$ at the top and $5 \mathrm{~m}$ at base. Cliff face transects were approximately vertical, but were moved accordingly if the climbing route migrated from the plumb line. Similarly, we sampled unclimbed sites along the path most likely to be chosen by a rock climber. Cliffs in NERI have a low density of higher plants, so a $2 \mathrm{~m}$-wide belt transect was centered over the cliff face to record the presence of vascular plants along the entire cliff height. After field reconnaissance, we determined that a $2 \mathrm{~m}$ wide transect most appropriately encompassed the potential area used by a climbing route. Within the transect, we stationed $1 \mathrm{~m}^{2}$ quadrats at $6 \mathrm{~m}$ intervals along the face to record finer details of cliff structure and lower plant and lichen life forms. Depending on the height of the cliff ( $\mathrm{min}=12 \mathrm{~m}$; $\max =38 \mathrm{~m}$ ), we placed a minimum of three and maximum of five quadrats within each cliff transect. We positioned a quadrat $1 \mathrm{~m}$ upward from ground level as well as at the apex of the vertical plane at the top of the cliff face, or if present, centered over fixed climbing anchors to best capture the start and end of the climbing area (Farris 1998). On unclimbed sites, we predetermined a logical ending point based on where a rock climber would likely finish the climb using these criteria: a) climbing difficulty changed dramatically, b) a large ledge or impassable roof system was apparent, c) the rock quality deteriorated, or d) the climb reached the summit of the cliff. 


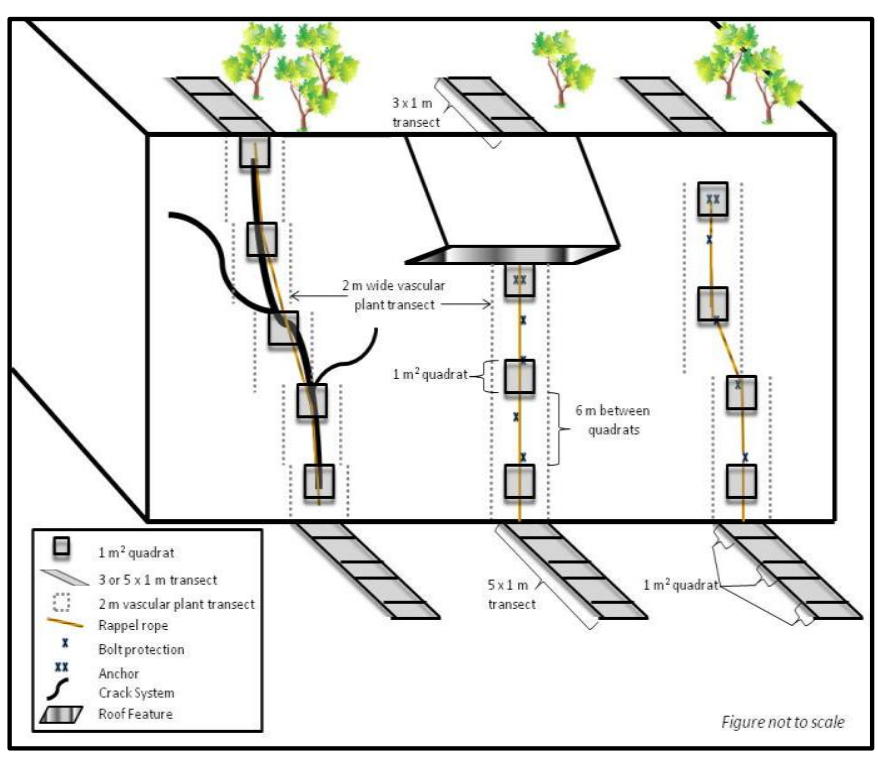

Figure 2.5: Field study design

\section{Physical Measurements}

At each site, we recorded geographic and physical data such as GPS location, elevation, cliff aspect, and information specific to the rock climb (e.g., presence of fixed anchors and style). Using a weighted cord marked at $1 \mathrm{~m}$ increments, we measured cliff height to the nearest $0.5 \mathrm{~m}$, overall cliff angle (slope) to the nearest degree using a Johnson Professional Angle Locator, and tallied the frequency of macrotopographic features, such as roofs, ledges $(>1 \mathrm{~m})$, or large crack systems $(>10$ $\mathrm{cm}$ ). Within each $1 \mathrm{~m}^{2}$ quadrat, we calculated the volume of all microtopographic features such as crevices, overlaps, and horizontal and vertical edges based on length and width measurements to the nearest centimeter (Kuntz and Larson 2006b). We also noted ecological determinants such as canopy cover as well as evidence of anthropogenic disturbance (e.g., trash, mechanical damage to trees, trails, climbing chalk, hiker lookouts, climbing gear, etc). We ranked all cliff positions by actual use intensity using field methods described in Saladyga (2011), including: extent of hardened zone (e.g., visible roots, trampled vegetation, or compacted/loss of $\mathrm{O}$ and A soil horizons; Hammitt \& Cole, 1998), root exposure, soil A-horizon exposure, trash, and human presence.

At cliff base and top, where a hardened (compacted; trampled) zone could be identified, we measured the length of that zone to the nearest $0.1 \mathrm{~m}$. We measured depth of litter and soil organic horizon in each quadrat to the nearest $\mathrm{cm}$ and we ranked root exposure using predetermined criteria accounting for the ratio of native soil depth to the number of bare macro- and microfilamentous roots. At cliff base sites where a dripline was present (moisture zone perimeter caused by a roof or overhanging cliff), we measured the distance from cliff base to dripline to the nearest $0.1 \mathrm{~m}$.

\section{Vegetation Sampling}

We collected vegetation data between May - September, 2010 to coincide with the flowering seasons for vascular plants. Within each vascular plant transect, all vascular species were recorded and identified. Unknown vascular specimens were collected and preserved in a plant press for identification at a later date. Within each $1 \mathrm{~m}^{2}$ quadrat, all non-vascular plants were identified and recorded. Given the difficulty of identifying many specimens in the field, we sampled unknown 
specimens and delivered them to specialists for laboratory identification (Lichens: Don Flenniken; Bryophytes: Susan Studlar; Vascular: Jim Vanderhorst, Brian Streets, Elizabeth Byers, and Donna Ford-Werntz). When a suitable specimen was not available, a sample was collected from outside of the quadrat most closely resembling the original specimen.

\section{Statistical Analysis}

We calculated species richness (SR) for each cliff position (top, face, base) and for four taxonomic groups: vascular, bryophyte, lichen, and total (aggregated). Because different total areas were sampled on cliff faces depending on the height of the cliff, we used rarefaction in Program-R Vegan to attain a transformed species richness constructed from a rarefaction curve (Sanders 1968; Gotelli and Colwell 2001; Oksanen 2012; Oksanen et al. 2012). Rarefied species richness on cliff face is hereby referred to as species richness (SR). To analyze soils, we averaged soil depth measurements across quadrats at the base and top of each site.

Using T-tests, we tested for significant differences $(\alpha=0.05)$ between normally distributed groups, such as cliff structure and rock climb statistics (e.g., establishment date, style). To estimate relationships between species diversity and climb difficulty and use intensity, we used simple linear regression (LR). We used a general linear model (GLM) to examine relationships between species richness and multiple variables and their interactions, including climb difficulty, use intensity, and style. Due to heterogeneity in cliff environments and our stratified sampling regime, many data within groups were non-normally distributed. Here we used the non-parametric Kruskal-Wallis (KW) test to analyze differences in median values.

\section{Results}

Of 112 cliff sites sampled, we used 111 in our analysis; one site was removed from the study because it was deemed unrepresentative of a rock climb by the first author and the first ascentionist (K. Parker, personal communication, April 4, 2011). We selected 17 beginner (5.6-5.8), 22 intermediate (5.9-5.10d), 20 experienced (5.11a-5.12b), and 20 expert level (5.12c-5.14) rock climbs in the analysis, totaling 79 climbed sites. We classified sample sites by potential use intensity class including 20 low, 20 moderate, and 20 high use and 19 extreme use sites (Table 2.1). As controls, we used 32 unclimbed cliff sites where we assigned an approximate climb difficulty using YDS and then grouped the sites into the four difficulty classes. In total, we sampled 1,113-1 $\mathrm{m}^{2}$ quadrats with 437 positioned on cliff faces and 338 at both cliff base and cliff top, respectively. Out of a possible 89 cliff sectors described by the local climbing guidebook, we sampled sites located within 52, representing approximately $60 \%$ of climbed Nuttall Sandstone cliffs described in NERI (Williams 2010).

Both north-facing and south-facing cliffs were well represented, representing 43 and 57\% of the samples, respectively. The average time required to walk to a climbed site was 17 ( \pm 9 STD) minutes, with a minimum of 3 and maximum of 50 minutes. Of climbed sites, $22 \%$ were classified as 0 stars $(\mathrm{n}=17), 29 \%$ as 1 star $(\mathrm{n}=23), 21 \%$ as 2 stars $(\mathrm{n}=17), 17 \%$ as 3 stars $(\mathrm{n}=14)$, and $10 \%$ as 4 stars ( $\mathrm{n}=8$; Williams, 2010). Climbed sites were roughly equally split by style, with 42 traditional and 37 sport climbs represented in this study. Every sport climb and $40 \%(n=17)$ of traditional climbs sampled was equipped with permanent bolted anchors systems at the cliff top or apex, totaling $68 \%(n=54)$ of all climbed sites. Of sites with permanent anchors, $67 \%$ of anchor systems were located $>2 \mathrm{~m}$ below the cliff apex, and these sites $(n=36$, or $45 \%$ of all climbed sites; Figure 2.6) sustain more vegetation between the anchors and cliff top than other sites. Nearly all (96\%) 
climbed cliff faces without anchors were clear of vegetation just below the cliff apex (25 out of 26, or $32 \%$ of all climbed sites).

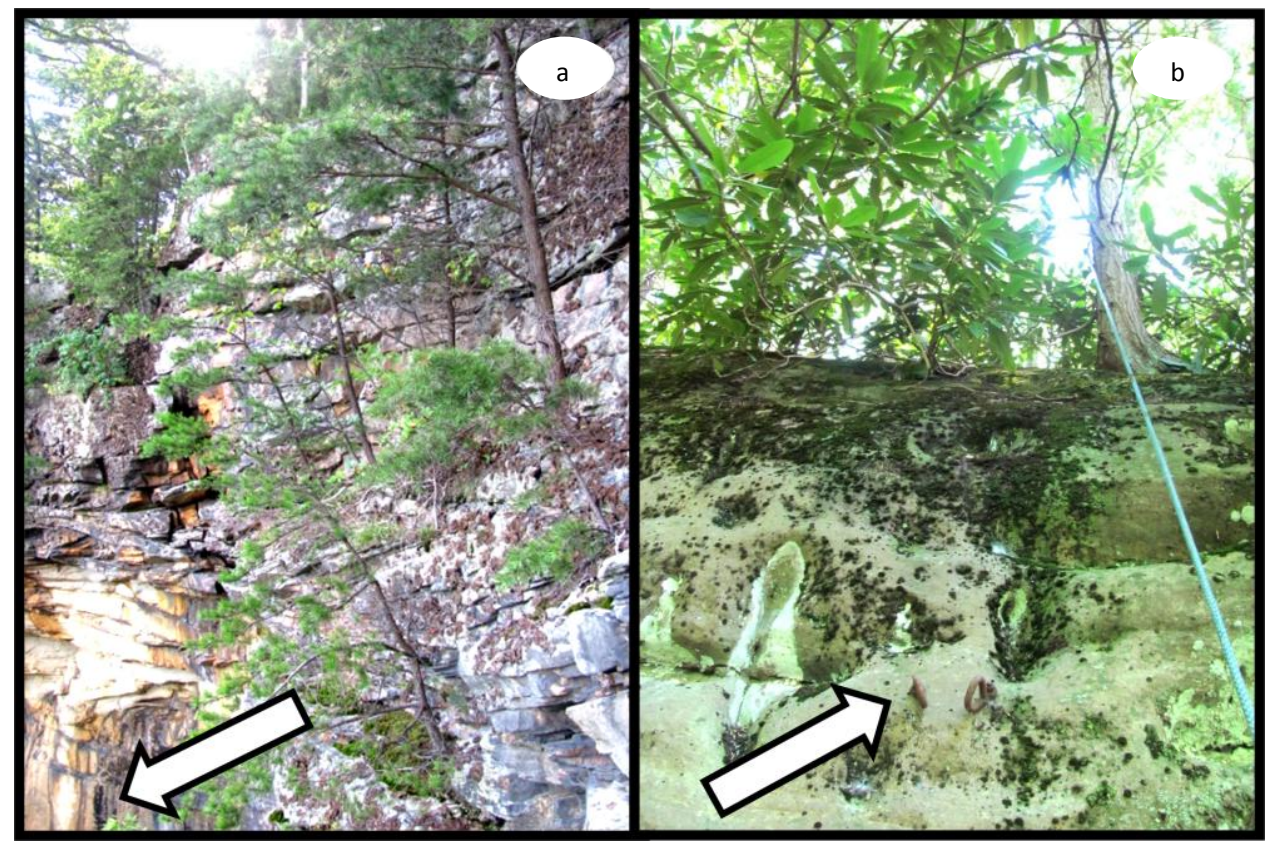

Figure 2.6: a) the biologically rich cliff apex with b) anchors placed below cliff top preventing impacts from trampling. Arrows point to anchors.

Mean year since climb establishment date (first documented ascent) for climbed sites is $20.2 \pm 5.2$ years. T-tests reveal a significant difference by style, where sport climbs were established more recently than traditional climbs $(18.0 \pm 3.8$ vs. $22.1 \pm 5.6$ years, respectively, $P<0.01)$. There is a weak but significant linear relationship between climb difficulty and establishment date, where more challenging rock climbs were established most recently (LR; $\mathrm{r}^{2}=0.12 ; P<0.01 ; \mathrm{n}=79$ ). We observed no relationship between use intensity and establishment date.

The most common evidence of anthropogenic influence at climbed sites are trails, mechanical damage to trees, trash, and overlooks (Appendix Table 2.1). We recorded the most human disturbances at cliff bases where we found $74 \%$ with trails $(n=58), 18 \%$ with trash $(n=14)$, and $15 \%$ with tree damage $(n=12)$. Less than one quarter $(22 \% ; n=17)$ of climbed cliff bases recorded no evidence of anthropogenic presence. At cliff tops, $29 \%$ had trails $(n=23), 8 \%$ were associated with overlooks $(n=6)$, and $6 \%$ sustained tree damage $(n=5) .62 \%$ of climbed cliff tops recorded no visible evidence of anthropogenic presence $(n=48)$. Few observations of anthropogenic impacts were made on cliff face, where $41 \%(\mathrm{n}=32)$ had climbing chalk (magnesium carbonate), $4 \%$ had trash $(n=3)$, and $1 \%$ sustained tree damage $(n=1) ; 55 \%$ of climbed cliff faces had no visual evidence of anthropogenic presence $(n=43)$.

In Chapter Three, Clark measures 97 linear $\mathrm{km}$ of cliff in the study area, or $38 \mathrm{~km}$ of Nuttall Sandstone. Our sample design assumes that a rock climbing route encapsulates a $2 \mathrm{~m}$ wide vertical strip of cliff. Under this assumption, we suspect that rock climbing routes in NERI interact with approximately 3,500 linear meters of cliff, or $9 \%$ of Nuttall Sandstone cliffs and 3.6\% of total cliff face. We do not have data for cliff base of cliff top but expect greater areas of impact associated with climbing activity at cliff base and less at cliff top compared to cliff face. 


\section{Cliff Structure}

Of all sites sampled, mean cliff height was $24.2 \mathrm{~m}$ ( $\pm 6.6 \mathrm{~m} \mathrm{STD})$, while mean transect height was $20.9 \mathrm{~m}( \pm 6.0 \mathrm{~m} \mathrm{STD})$. We found that cliff angle is positively correlated with difficulty (Figure $2.7 ; \mathrm{r}^{2}$ $=0.63 ; P<0.01)$. Corresponding with these findings, cliff bases of expert level climbs have significantly greater dripline lengths (median: $4.0 \mathrm{~m}$, interquartile range [IQR]: $6.1 \mathrm{~m}$ ) compared to other difficulty classes (aggregated median: $0.0 \mathrm{~m}$, IQR: $1.0 ; P<0.01$ ). As climb difficulty increases, we found the frequency of ledges $(>1 \mathrm{~m})$ and microtopographic features declines (Figure 2.8). Statistically, sites were not structurally different (e.g., angle, height, macro- and microtopographic features) by site type (climbed vs. unclimbed) or within grade classes (K-W; $P>0.2$ across tests).

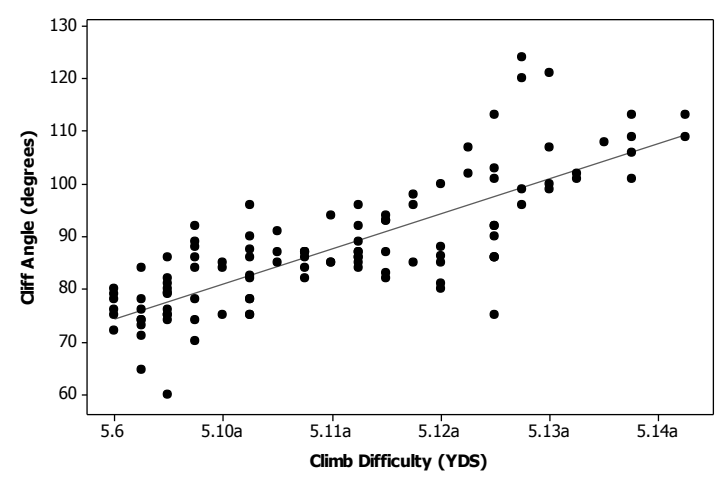

Figure 2.7: Linear relationship between climb difficulty (YDS) and cliff angle (degrees from level ground). $r^{2}=0.63 ; p=0.000$.
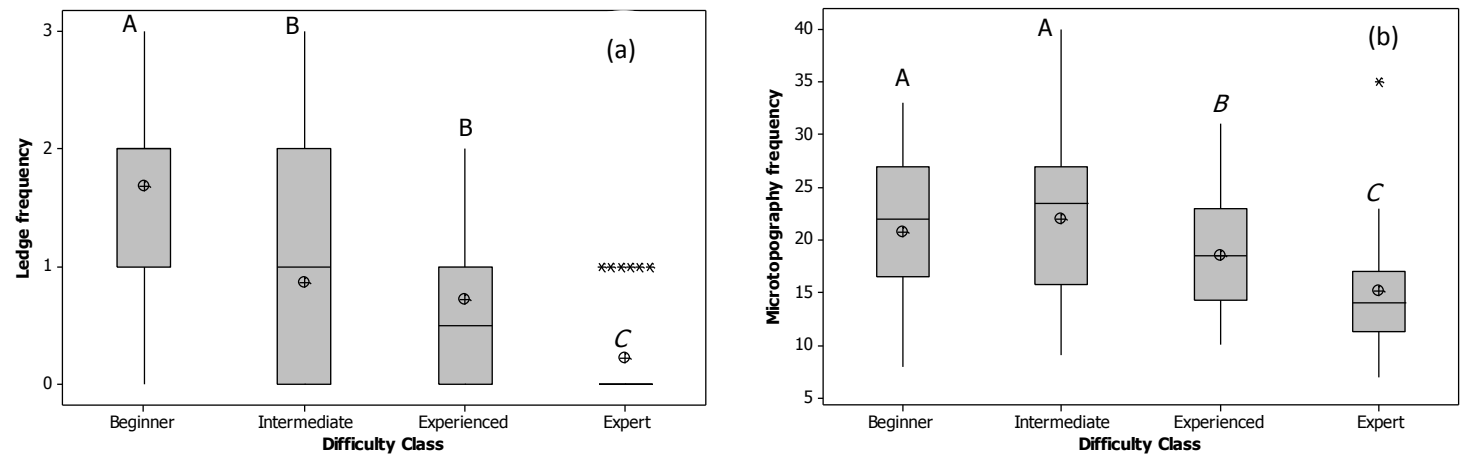

Figure 2.8a-b: Box plots between climb difficulty class and cliff face topography: a) ledge frequency ( $>1 \mathrm{~m}$ ), and b) microtopography frequency. Statistical significance is calculated using Kruskal-Wallis test. Bars that share a letter code are not significantly different from one another at $\alpha=0.05$. Grey boxes represent the interquartile range, horizontal lines are median values, and crosshairs are mean values.

\section{Diversity}

Throughout all cliff positions, we made 7,997 plant observations with 4,200 lichens, 2,395 vascular plants, and 1402 bryophyte samples observed and identified. We found 332 different plant species across all sites (122 lichen species, 121 vascular plant species, and 87 bryophyte species). The greatest diversity of lichens and bryophytes are found on cliff tops ( $\mathrm{n}=93$ and 59, respectively) while cliff faces harbored the greatest diversity of vascular plants $(n=75)$. Results for vascular specimens are likely elevated on cliff faces relative to bryophytes and lichens due to larger areas sampled. At the site level, total and lichen SR is consistently greater on cliff top and cliff face than 
on cliff base, while the numbers of bryophyte and vascular species are comparable across cliff positions (Table 2.2).

\begin{tabular}{cccccc}
\hline \hline Cliff Position & Taxonomic Group & Median & IQR & Min & Max \\
\hline \hline \multirow{3}{*}{ Base } & Total SR & 9 & 10 & 0 & 31 \\
& Vascular SR & 2 & 4 & 0 & 9 \\
& Bryophyte SR & 2 & 3 & 0 & 8 \\
& Lichen SR & 5 & 7 & 0 & 20 \\
\multirow{3}{*}{ Face } & Total SR & 16 & 10 & 0 & 32 \\
& Vascular SR & 4 & 5 & 0 & 11 \\
& Bryophyte SR & 2 & 4 & 0 & 8 \\
Top & Lichen SR & 10 & 5 & 0 & 17 \\
& Total SR & 16 & 8 & 2 & 30 \\
& Vascular SR & 3 & 4 & 0 & 13 \\
& Bryophyte SR & 3 & 3 & 0 & 8 \\
& Lichen SR & 9 & 8 & 0 & 21 \\
\hline
\end{tabular}

Table 2.2: Species richness by taxonomic group (total, vascular, bryophyte, and lichen) at each cliff position (cliff base, face, and top). IQR: Interquartile range

\section{Face}

We compared SR on all cliff faces (climbed and unclimbed) and found as climb difficulty increases, SR declines, regardless of taxonomic group (LR; total SR: $\mathrm{r}^{2}=-0.33 ; P<0.01$, vascular SR: $\mathrm{r}^{2}=-0.31$; $P<0.01$, bryophyte SR: $\mathrm{r}^{2}=-0.2 ; P<0.01$, lichen SR: $\mathrm{r}^{2}=-0.19 ; P<0.01$; Figure 2.9). We compared median SR between site type (climbed vs. unclimbed) as well as subdivided by grade class and found no significant differences in species richness across all taxonomic group (Appendix Table 2.2). 

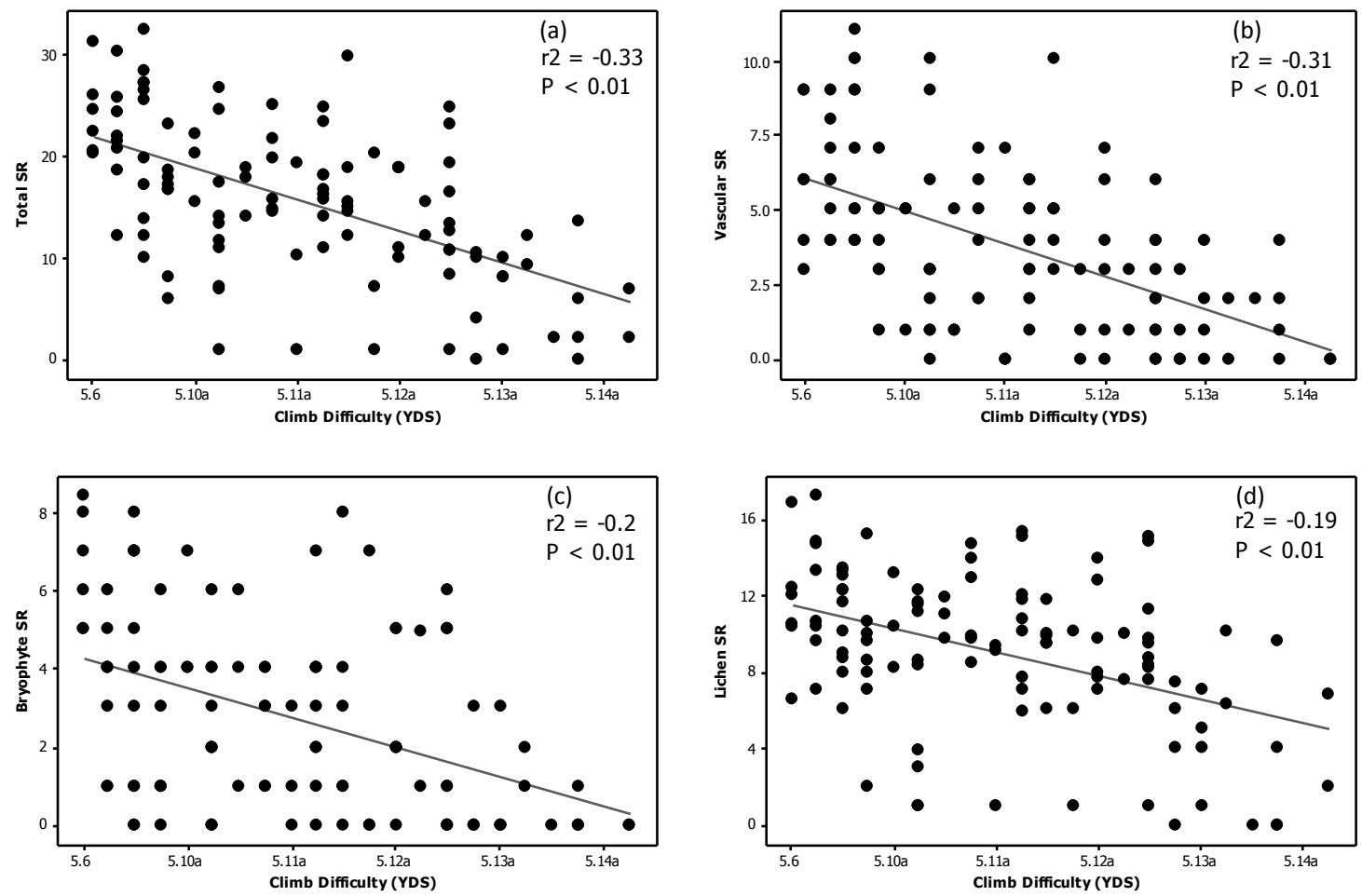

Figures 2.9a-d: Linear relationships between cliff face species richness (SR) on cliff faces across four taxonomic groups (a: total SR; b: vascular SR; c: bryophyte SR; d: lichen SR) and climb difficulty, regardless of site type.

We compared use intensity classes at climbed sites to all unclimbed sites, and found that sites with low use consistently sustain greater SR than unclimbed (Figure 2.10). Conversely, extreme use sites consistently sustain fewer species, with $33 \%$ fewer total species (K-W; $\mathrm{n}=5.86 ; P<0.01$ ). Lichen SR declined most significantly at extreme use sites, where $29 \%$ fewer species are present relative to unclimbed sites $(\mathrm{K}-\mathrm{W} ; \mathrm{n}=2.87, P<0.01)$. We found no differences in SR across all taxonomic groups by climb style, regardless of use intensity or grade class. 

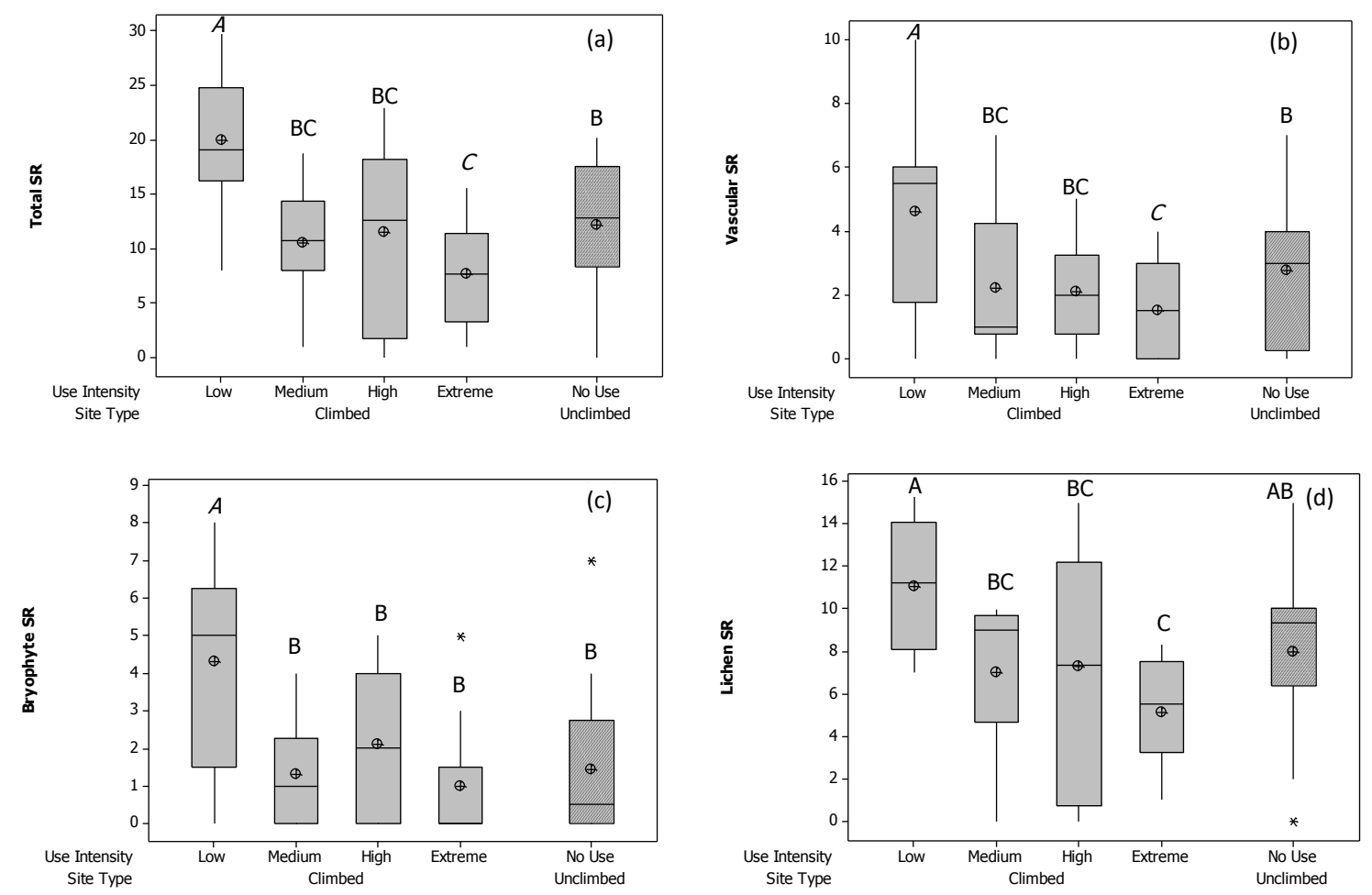

Figure 2.10: Box plots compare species richness (SR) on cliff faces across four taxonomic groups (a: total SR; b: vascular SR; c: bryophyte SR; d: lichen SR) by site type and use intensity class. Climbed sites are signified as grey boxplots, where unclimbed sites contain hash lines. Statistical significance is calculated using Kruskal-Wallis test. Bars that share a letter code are not significantly different from one another at $\alpha=0.05$. Grey boxes represent the interquartile range, horizontal lines are median values, and crosshairs are mean values

We included climb difficulty, use intensity, and an interaction term in a GLM (Table 2.3, Figure 2.11) and found use intensity and climb difficulty exhibit some predictive power for total SR and bryophyte SR (adj $r^{2}=0.53$ and $0.45, P<0.01$, respectively). Use intensity weakly but positively contributes to the model for lichen SR but did not improve the model's performance for vascular SR. We found no significant interaction between use and difficulty. 


\begin{tabular}{|c|c|c|c|c|c|c|c|c|c|c|}
\hline Response & Source & DF & Seq SS & Adj SS & Adj MS & $\mathbf{F}$ & $\mathbf{P}$ & $\mathbf{S}$ & $\mathbf{r}^{2}$ & Adj $r^{2}$ \\
\hline \multirow{4}{*}{ Total SR } & Grade & 20 & 3168.46 & 2269.34 & 113.47 & 4.11 & 0.000 & \multirow{4}{*}{5.25694} & \multirow{4}{*}{0.708} & \multirow{4}{*}{0.528} \\
\hline & $C U I$ & 22 & 1390.88 & 1390.88 & 63.22 & 2.29 & 0.005 & & & \\
\hline & Error & 68 & 1879.21 & 1879.21 & 27.64 & & & & & \\
\hline & Total & 110 & 6438.55 & & & & & & & \\
\hline \multirow{4}{*}{ Vascular SR } & Grade & 20 & 385.98 & 284.86 & 14.24 & 2.66 & 0.001 & \multirow{4}{*}{2.31490} & \multirow{4}{*}{0.585} & \multirow{4}{*}{0.329} \\
\hline & $C U I$ & 22 & 128.02 & 128.02 & 5.82 & 1.09 & 0.383 & & & \\
\hline & Error & 68 & 364.40 & 364.40 & 5.36 & & & & & \\
\hline & Total & 110 & 878.40 & & & & & & & \\
\hline \multirow{4}{*}{$\begin{array}{l}\text { Bryophyte } \\
\text { SR }\end{array}$} & Grade & 20 & 218.94 & 187.75 & 9.39 & 2.85 & 0.001 & \multirow{4}{*}{1.81459} & \multirow{4}{*}{0.659} & \multirow{4}{*}{0.449} \\
\hline & CUI & 22 & 214.16 & 214.16 & 9.73 & 2.96 & 0.000 & & & \\
\hline & Error & 68 & 223.91 & 223.91 & 3.29 & & & & & \\
\hline & Total & 110 & 657.01 & & & & & & & \\
\hline \multirow{4}{*}{ Lichen SR } & Grade & 20 & 742.37 & 562.34 & 28.12 & 2.76 & 0.001 & \multirow{4}{*}{3.18891} & \multirow{4}{*}{0.611} & \multirow{4}{*}{0.37} \\
\hline & $C U I$ & 22 & 342.96 & 342.96 & 15.59 & 1.53 & 0.093 & & & \\
\hline & Error & 68 & 691.50 & 691.50 & 10.17 & & & & & \\
\hline & Total & 110 & 1776.83 & & & & & & & \\
\hline
\end{tabular}

Table 2.3: GLM regression between species richness (SR; response) on cliff faces across four taxonomic groups (total SR, vascular SR, bryophyte SR, and lichen SR) predicted with use intensity (CUI) and climb difficulty (Grade [YDS]).
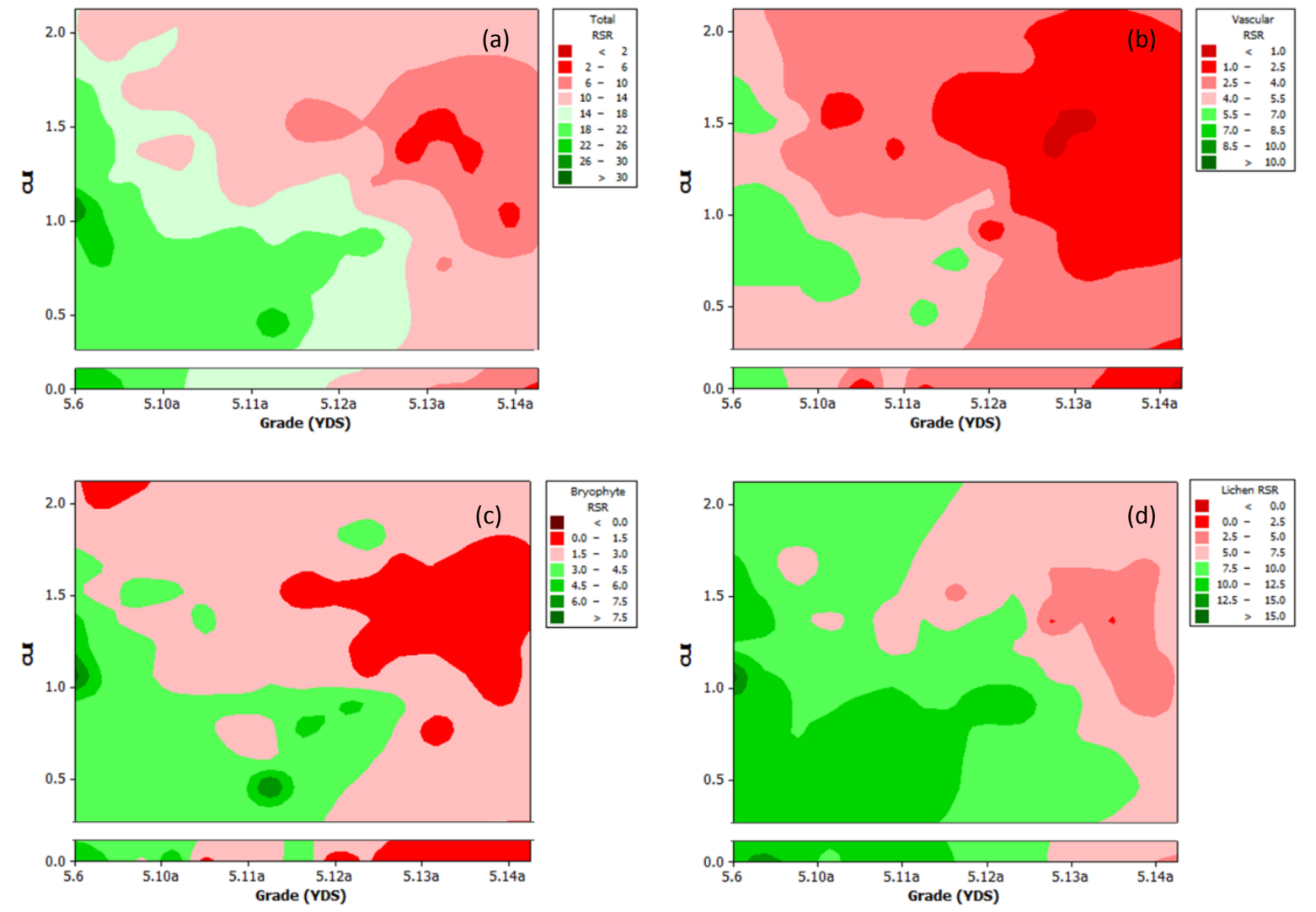

Figure 2.11: a-d: Contour graphs of cliff face SR across four taxonomic groups (a: total SR; b: vascular SR; c: bryophyte SR; d: lichen SR) displayed using use intensity (CUI; y-axis) and climb difficulty (Grade [YDS]; x-axis). CUI values of " 0 " are unclimbed control sites 


\section{Base}

Compared to unclimbed sites, climbed sites sustain 53\% less litter depth (climbed median depth: $1.33 \mathrm{~cm}$, IQR: $2.67 \mathrm{~cm}$; unclimbed median depth: $2.83 \mathrm{~cm}$, IQR: $2.0 \mathrm{~cm}$; K-W; $P<0.05$ ) and $41 \%$ less organic soil depth (climbed median depth: $1.67 \mathrm{~cm}$, IQR: $3.67 \mathrm{~cm}$; unclimbed median depth: $2.83 \mathrm{~cm}$, IQR: $3.13 \mathrm{~cm}$; K-W; $P<0.01$; Appendix Figure 2.2). When we analyzed soils on climbed versus unclimbed sites by distance from base, we only found significant declines in organic soil depths on climbed sites at $2.5 \mathrm{~m}(P<0.01)$, while litter statistically diverged at all distances: $0.5 \mathrm{~m}, 2.5 \mathrm{~m}$, and $4.5 \mathrm{~m}(P<0.01)$. We found no linear trends between grade class and soil depth at cliff base, however expert level climbs sustain $>85 \%$ less median organic soil depth $(0.33 \mathrm{~cm}, \mathrm{IQR}: 1.5 \mathrm{~cm})$ compared to all other grade classes (aggregated depth: $2.67 \mathrm{~cm}, \mathrm{IQR}: 3.33 \mathrm{~cm}$; K-W; $P<0.01$; Appendix Table 2.3). When analyzed by difficulty class and site type, we only found significantly less organic horizon depths at beginner level climbed sites, $(\mathrm{K}-\mathrm{W}$; litter: $P=0.08$ and organic soil: $P$ $<0.01$; Appendix Table 2.4). Only moderate and extreme use sites sustained significantly less litter and organic soils than unclimbed sites $(70 \%$ and $94 \%$ declines, respectively; Figure 2.12). We found no significant interaction between use intensity and climb difficulty in controlling impacts to soil depth.

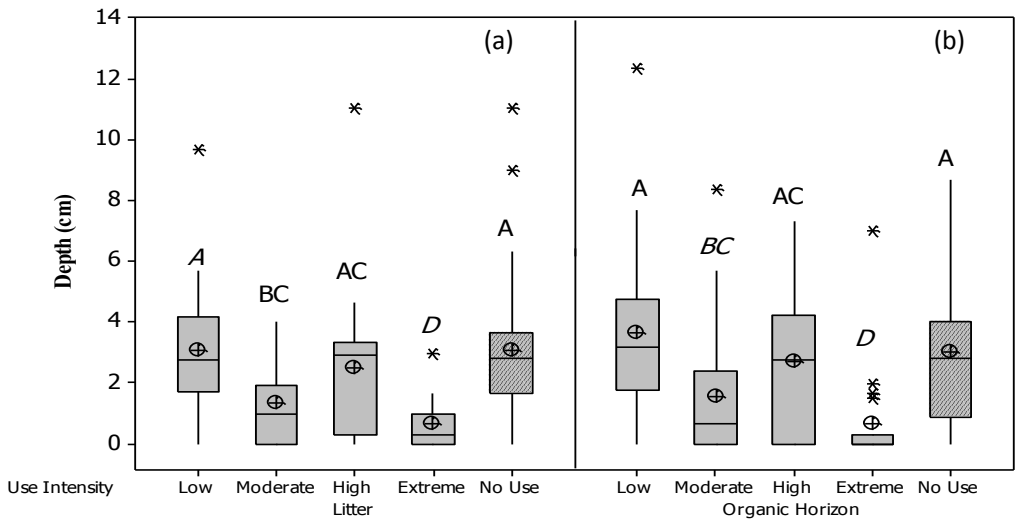

Figures 2.12a-b: Box plots of (a) litter and (b) organic horizon soil depths ( $\mathrm{cm}$ ) by use Intensity and site Type. Climbed sites are signified as grey boxplots, where unclimbed sites contain hash lines. Statistical significance is calculated using KruskalWallis test. Bars that share a letter code are not significantly different from one another at $\alpha=0.05$. Grey boxes represent the interquartile range, horizontal lines are median values, and crosshairs are mean values

We observed a hardened zone at 73\% $(n=58)$ of all climbed cliff bases (median length: $3.0 \mathrm{~m}$, IQR: $6.0 \mathrm{~m}$ ). Of the sites with no hardened zone, we found no linear relationship with climb difficulty, but $65 \%(n=15)$ of climbs with no hardened zone were classified as low or moderate use and $66 \%$ $(n=14)$ were traditional climbs. We observed no statistically significant differences or trends in hardened zone length between difficulty classes. When analyzed by use intensity, we found median hardened zone length increases on average by 39\% $(1.0 \mathrm{~m})$ between each use intensity class (Figure 2.13; Appendix Table 2.5). We analyzed hardened zone length by style and found no significant differences between traditional or sport climb (Appendix Figure 2.1). We found no relationship between hardened zone lengths and use intensity or climb difficulty at sport climbs. Climbs with anchors sustained a significantly greater median hardened zone length compared to climbs without anchors (4.0 m, IQR: $5.0 \mathrm{~m}$ vs. $1.8 \mathrm{~m}$, IQR: 3.75; K-W; $P<0.01$ ). 


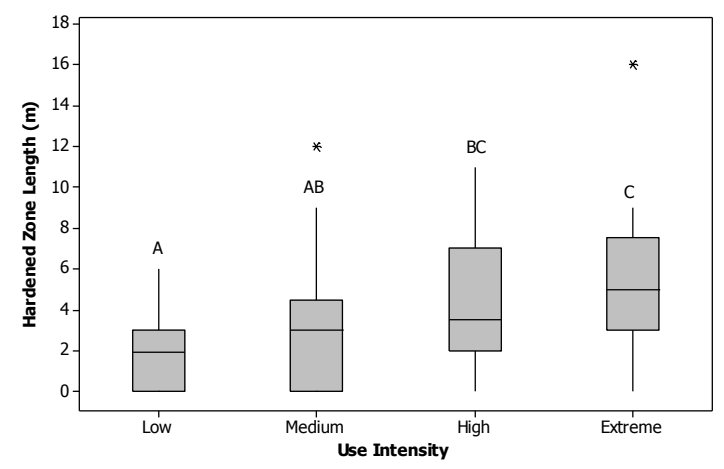

Figure 2.13: Hardened zone lengths at cliff base climbed sites by use intensity class. Statistical significance is calculated using Kruskal-Wallis test. Bars that share a letter code are not significantly different from one another at $\alpha=0.05$. Grey boxes represent the interquartile range, horizontal lines are median values, and crosshairs are mean values

We found no linear trends between difficulty and species richness at cliff bases regardless of taxonomic group, but significantly fewer bryophytes (median: 0, IQR: 3.0; K-W; $P<0.01$ ), vascular plants (median: 1, IQR: 2.0; K-W; $P<0.05$ ), and total species (median: 4.5, IQR: $9.75 ; \mathrm{K}-\mathrm{W} ; P<0.05$ ) were present at expert level sites as compared to other difficulty classes (cumulative medians: bryophyte SR: 3.0, IQR: 3.0; vascular SR: 3.0, IQR: 3.0; total SR: 11.0, IQR: 10.0; Appendix Table 2.6). Species richness across the four taxonomic groups is not significantly different between climbed and unclimbed sites. When further subdivided by climb difficulty, beginner level climbs sustain $42 \%$ fewer bryophyte species than unclimbed sites ( $=1.5$; K-W; $P<0.05$; Appendix Table 2.7). When compared by use intensity and site type, vascular SR is significantly reduced at extreme use sites (K-W; $P<0.05)$. We found no interaction between use intensity and climb difficulty on species richness.

\section{Top}

At the cliff top, we measured no significant differences in soil depth (averaged or by distance) between climbed and unclimbed sites, climb difficulty, or use intensity. Median hardened zone length at all climbed sites aggregated by type is $0.0 \mathrm{~m}$ (IQR: $0.0 \mathrm{~m}$ ). We observed no linear trends between hardened zone length and climb difficulty or an interaction between use intensity and difficulty. Of all climbed sites, $18 \%$ have a hardened zone greater than $0.5 \mathrm{~m}(\mathrm{n}=15$; median: $3.0 \mathrm{~m}$, IQR: $3.0 \mathrm{~m})$. Of this subset, $80 \%(\mathrm{n}=12)$ are high to extreme use, $80 \%(\mathrm{n}=12)$ are traditional climbs, and $80 \%(n=12)$ are beginner to intermediate level sites (Figure 2.14). There is no significant difference between hardened zone lengths of sites with anchors compared to those without anchors. We recorded no significant differences in SR across the taxonomic groups by site type, climb difficulty, use intensity, style, or their interactions at the top. 


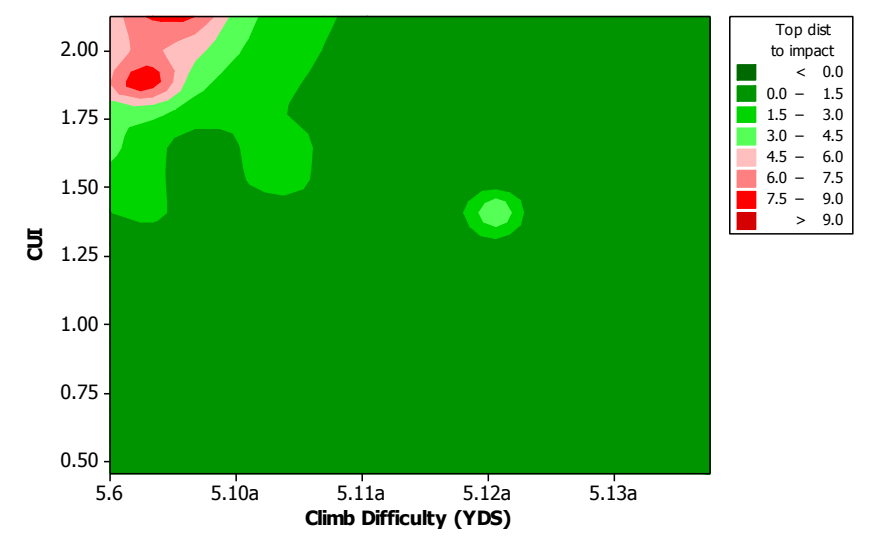

Figure 2.14: Contour graph of hardened zone length at cliff top by use intensity (CUI; y-axis) and climb difficulty (YDS; $x$-axis)

\section{Discussion}

Cliffs are one of the least studied terrestrial ecological communities globally (a search of ESA Journals produced no publications addressing plant diversity or plant communities on cliffs). Nevertheless, increasing use of cliffs by climbers has created a tremendous need for data about how recreation may affect plant diversity (Cordell 1999; Mahan 2004; National Park Service 2005; Attarian and Keith 2008; The Outdoor Foundation 2011). Our study builds on the limited studies of plant diversity and human impacts on cliffs by addressing gradients of use and climb difficulty (a proxy for cliff angle and microtopography) at multiple cliff positions and across different climbing styles. Our results, based on a large sample of cliffs in the New River Gorge, West Virginia indicate that climb difficulty, use intensity, and climb style all condition the response of plant diversity to climbing.

\section{Face}

Climb difficulty, here defined by the Yosemite Decimal System (YDS) is strongly related to cliff angle (Figure 2.7) and cliff topography (macro and microtopography; Figure 2.8a-b). We found that introductory level climbs have low cliff angles and sustain more ledges $(>1 \mathrm{~m})$ and microtopographic features while more challenging climbs are steeper with fewer ledges and microtopographic features. Our results from unclimbed cliffs strongly indicate that low cliff angles and presence of micro- and macrotopographic features are also associated with high plant diversity (Figure 2.11a-d; see Chapter Three) This finding supports Kuntz \& Larson (2006), who demonstrated that plants are limited by cliff microtopography but provides new information about the importance of cliff angle. Low cliff angles allow for greater light exposure, higher rates of soil development, and a greater number of rooting spaces, providing more resources for all taxonomic groups studied here. Similarly, water may be more available on low angle cliffs, where rainfall is intercepted and runoff tracks the cliff face, carrying nutrients, seeds, and organic matter. On vertical or overhanging cliffs, water is only available through atmospheric humidity, driplines, or seeps and overhanging features diminish light. 
Our results for cliff angle, cliff structure, and plant diversity indicate that studies focused on a narrow range of climb difficulties, cliff angles, or cliff structures represent only a small portion of cliff types used in the current state of rock climbing and may include only a narrow range of plant communities (Nuzzo 1995; Kelly and Larson 1997; Camp and Knight 1998; McMillan and Larson 2002). Based on these results, we suggest that climb difficulty, derived from the Yosemite Decimal System (or other climb difficulty rating system), may be used by managers as a surrogate for cliff structure, angle, and plant diversity. This would provide a simple tool to help managers identify cliffs with high plant diversity suitable for monitoring, mitigation, or management. Our results are limited to a single geologic unit and should be confirmed at other locations with different geology. Further, though low cliff angles may promote high plant diversity, rare taxa or rare plant communities may occur on high angle cliffs, and deserve further study. In future works, we will explore variability in ecological communities through community classification and ordination with the objective of identifying physical conditions that control cliff communities. Lastly, we will explore the response of plants by growth form since some may be more susceptible than others to disturbance (e.g., crustose vs. umbilicate lichens).

Though climb difficulty is a strong predictor of plant diversity on cliffs, our study also demonstrates the importance of use intensity on plant diversity. For example, on the cliff face, plant diversity declines with increased use intensity, regardless of difficulty class or taxonomic group (Table 2.3; Figures 2.8a-d). Our combined model of climb difficulty and use intensity explains over $50 \%$ of the variability in total cliff face SR, 33\% for vascular SR, 45\% for bryophyte SR, and 37\% for lichen SR. Our findings support Camp \& Knight's (1998) observation of a decrease in the number of plant taxa associated with use and help explain why Nuzzo (1996) and Walker et al. (2004) found no difference in cliff face vegetation on climbed versus unclimbed cliffs. We suggest that variability in some studies can be explained by use intensity and climb difficulty (e.g., structure). For example, one study (McMillan and Larson 2002) sampled popular climbed sites of 5.9 (YDS) difficulty and found declines in species richness when compared to unclimbed sites of a similar structure. Only when we specifically select for high-extreme use sites (e.g., popular) of a comparable difficulty from a subset of our data, we observe similar trends in species richness where lichen populations are most significantly impacted (KW; $P<0.01)$. Our results highlight the importance of both climb difficulty (e.g., angle and structure) and use intensity as moderators of cliff face vegetation.

There is a caveat to our general observation of decreasing diversity with increased use: with the exception of lichens, low use sites sustained more species than unclimbed sites. We attribute this finding to one of two phenomena: 1) the intermediate disturbance hypothesis (IDH; (Connell 1978; Ward and Stanford 1983; Dial and Roughgarden 1988; Collins, Glenn, and Gibson 1995), or 2) our method for selecting unclimbed sites. While some successional processes on cliffs have been explored (Oosting and Anderson 1939; Keever, Oosting, and Anderson 1951; Ursic, Kenkel, and Larson 1997), disturbance has long been considered less important and the IDH has never been documented as a process governing cliff environments. Under the IDH, species diversity is amplified at low-intermediate levels of disturbance. At no-low levels of disturbance, competitive organisms are primed to dominate the system, while at high levels of disturbance all species are at risk of local extirpation. The initial development of a rock climb is considered the greatest disturbance to cliff faces (McMillan \& Larson, 2002; Kuntz \& Larson, 2006a; Attarian \& Keith, 2008), where faces are "cleaned" of excess vegetation, soil, and loose rock. In NERI, where most rock climbs sampled were established 20 years prior to this study, our research suggests that unpopular, low use sites contain high species richness, perhaps a legacy of the initial disturbance and continued occasional use. These results correspond with Camp \& Knight's (1998) observation of increased Bromus madritensis ssp. rubens L. proportions on "moderate use" climbed sites and suggest that low use by climbers may even enhance plant diversity on cliffs. 
The other possible explanation for high plant diversity on low impact cliffs relative to control sites is that the unclimbed control sites were a biased sample of unclimbed cliffs. When selecting unclimbed sites, we may have inadvertently selected sections of cliff that contained less vegetation and thus appeared more "climbable". Alternatively, many of the low use sites may be seldom climbed because they are heavily vegetated, wet, and dangerous (e.g., loose rock; Williams, 2010). In one circumstance, after consultation with the first ascentionist, one established rock climb classified as low use was removed from the study because it was deemed unrepresentative of a rock climb as it was "too vegetated". Interestingly, this site had over twice as many total species as compared to all sites used in this study.

\section{Cliff Base}

Soil (litter and organic horizon) depths were significantly reduced at climbed sites relative to unclimbed sites (Figure 2.12a-b), suggesting that the cliff base is the most consistently impacted cliff position. These results are consistent with McMillan \& Larson's (2002) who posit that climbers access the cliff base more regularly than cliff tops. We recorded significantly less organic soils (85\%) at expert level sites compared to all other difficulty classes (Appendix Table 2.3). We attribute this to the greater distance to the dripline and the presence of a talus base arising from fracturing and cleaving rocks from overhangs. Consistent with our observation, Olcott (2011a) observed a layer of shale below the thickest sandstone beds (e.g., tallest) at NERI, which were most consistently associated with advanced level climbs. Our results show a significant decline in organic soil depths at beginner difficulty classes (Appendix Table 2.4), suggesting that these sites are more heavily trafficked, regardless of climb popularity (star value). We did not observe an interaction between use intensity and climb difficulty that influenced soil depths.

We measured a hardened zone at a majority of climbed sites. No significant differences or trends were observed by grade class. We also found no significant differences in hardened zone length by climb style (Appendix Figure 2.1) which is inconsistent with Carr (2007) who found that sport climbs sustained significantly greater hardened zones. This divergence in results may be due to differences in preference in climb style between our study area and Carr's (Red River Gorge, KY). We do demonstrate a weak linear relationship between use intensity and hardened zone length on traditional climbs but not on sport climbs. These results support Carr (2007), who found that climb accessibility (e.g., trail length and road distance) is an important predictor of impacts at traditional climbs but not sport climbs. Variation in hardened zone length by style may be affected by climber preferences, where climbers appear to be more selective about the quality of traditional climbs, whereas sport climbs appear trafficked more consistently regardless of quality.

Species richness at cliff bases are consistent with results presented for soils and hardened area, however more variable. Expert level sites sustain fewer species at the cliff base (Appendix Table 2.6), which is likely due to: a) diminished organic soils and light levels associated with overhangs, b) presence of talus and/or a shale layer at the base, and/or c) increased length of the dripline. Climbed beginner level sites have significantly reduced diversity of bryophytes (Appendix Table 2.7), consistent with soils and hardened area results, emphasizing that these sites are most heavily used by rock climbers. Vascular species richness is only reduced at extreme use sites, indicating some level of vascular species resilience at lower and intermediate use classes. We did not find any interaction between use intensity and climb difficulty on species richness at cliff base.

\section{Cliff Top}

Few sites sampled in NERI sustain impacts to cliff tops directly attributed to climbing. We measured no relationship or differences in soil depths or species richness on cliff tops by site type 
(climbed vs. unclimbed), climb difficulty, or use intensity. These results correspond with observations made by Walker et al. (2004) who found relatively little disturbance to cliff tops associated with climbing, attributing these results to a "no top-out" (stopping climb below cliff top) policy for climbers at the Obed Wild and Scenic River in Tennessee. Though NERI does not have such a policy, less than one quarter of our sites had a measurable hardened zone at the top and those that did were most often classified as high use, beginner level, traditional climbs. These results add strength to Schuster, Thompson, and Hammit (2001) who used social surveys to demonstrate differences in climber use and management preferences by style and difficulty practiced. We speculate that the majority of impacts to cliff tops from rock climbing in NERI are confined to popular, traditional style rock climbs under grade 5.9 (YDS). However, most cliff top impacts are instead associated with social trails and hiker overlooks than for climbed trails. These results for NERI in line with observations made by McMillan \& Larson (2002) in the Niagara Escarpment. Due to their physical position and increased light levels, cliff tops in NERI display the greatest levels of plant diversity, supporting many specialized, vulnerable plant species such Carex spp., Danthonia sericea Nutt., Cladonia spp., Lasallia spp. Umbilicaria spp., and Dicranum spp. Impacts to cliff tops are of particular concern to land managers because these cliff positions represent only a fraction of the land area in the park yet provide the microhabitats that these species require.

\section{Importance of Study Design}

In disturbance ecology, comparative research is often confounded by ecosystem complexity and a lack of understanding of the environment prior to disturbance (Pickett and White 1986; Voller and Harrison 1998; McCune, Grace, and Urban 2002; McMillan and Larson 2002; Kuntz and Larson 2006b). Our study design successfully captures climbable cliff environments with and without anthropogenic disturbance by sampling across a gradient of climb difficulties and use intensities as well as selecting representative control sites. This is the first study of its kind to use climb difficulty and use intensity along gradients as moderators of disturbance and cliff biota. We include a large number of study sites, sample area per site (total $\mathrm{m}^{2}$ ), and numerous species recorded allowing us to identify impacts across a range of climb types, difficulties, and use intensities. We sampled $\sim 170 \%$ more study sites (70 more) than any previous studies of cliff ecosystems (Nuzzo 1995; Camp and Knight 1998; McMillan and Larson 2002; Walker et al. 2004; Kuntz and Larson 2006b). Only Farris sampled more sites ( $\mathrm{n}=153)$, but each only covered a $0.75 \mathrm{~m}$ area, or approximately $85 \%$ less area that in our study. We sampled 40\% more plant taxa (difference: 137 species) than in the comparable study with the highest number of taxa (McMillan \& Larson, 2002), although this is likely the product of increased sample area as well as differences in site location and local ecology. We credit our ability to comprehensively survey rock climbing in NERI to our access to the Williams (2010) rock climbing guidebook, which provided high resolution information about over 1700 rock climbs present in the gorge.

\section{Conclusion}

Our study provides evidence that impacts to cliff environments by climbing are moderated by climb difficulty, use intensity, and in some cases, climb style. Our results demonstrate that a presence/absence view of disturbance to cliffs may limit our understanding of recreational impacts on plant communities. On cliff faces, climb difficulty (e.g., cliff structure) and use intensity are clear predictors of diversity and can be used to guide management. Of all cliff positions, cliff base is most consistently impacted, but beginner level climbs sustain the greatest impacts to soils, bryophyte species richness, and hardened (compacted) zone lengths. Our field observations indicate that the 
majority of climbs have trails that traverse the base, regardless of use intensity. For management, we recommend that trails be rerouted away from cliff base, which may reduce impacts at all sites, regardless of popularity. We show that cliff tops are the least disturbed cliff position studied, and that impacts are largely confined to a subset of climbed sites: low difficulty (<5.9 YDS), popular, traditional climbs. Since cliff tops are biologically unique, however, emphasis should be placed on preserving them. We suggest management identify current and future target areas and establish a perimeter to limit enhanced impacts. Since impacts are confined to a subset of climbers (notably novices), targeted education of this group(s) may be beneficial. We found that anchors appear to preserve the cliff apex and cliff tops, but may lead to increased use at cliff base. We recommend the judicious placement of climbing anchors at moderate to high use sites, specifically placed $>2 \mathrm{~m}$ below cliff top as well as education to limit climbers from topping out. Lastly, special concern should be given to hiker trails and lookouts by defining perimeters, reducing social trails (and thereby the area impacted), and also by education of this user group. 


\section{CHAPTER THREE}

\section{Spatial, Structural, and Ecological Inventory of Cliff Environments in the New River Gorge, WV}

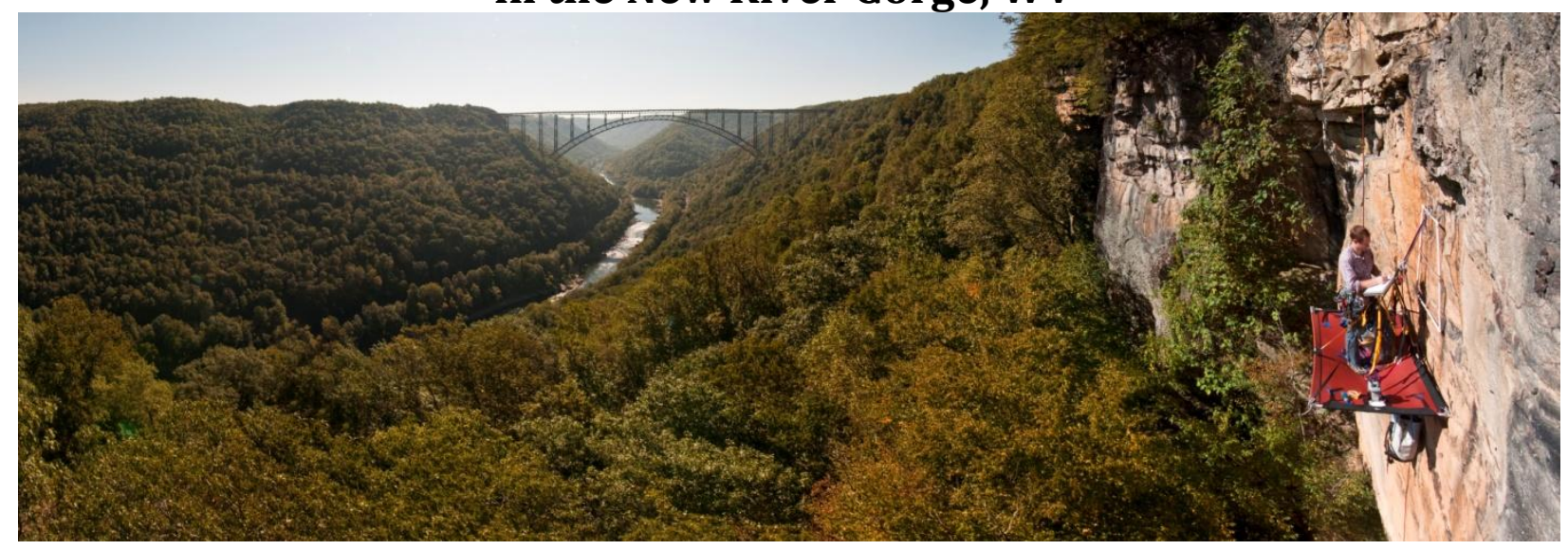

\section{Project Overview}

Despite the national significance of the cliffs at the New River Gorge, surprisingly little is known about their distribution, physical characteristics, and associated flora (Mahan 2004). For this project, we surveyed the spatial extent of cliffs using a GIS, measured environmental and structural attributes in the field, and inventoried cliff face vegetation including vascular plants, bryophytes, and lichens. Surveys were conducted across a range of environmental conditions to investigate the breadth of possible cliff types and species associations. The purpose of this report is to describe our preliminary results and act as primer for future projects. Our research objectives are:

Objective One: Assess the spatial distribution of cliffs and associated cliff face plant communities.

Objective Two: Describe cliff features and examine drivers of cliff face ecology.

Objective Three: Describe plant species on cliff faces, highlighting species of special interest.

This project was conducted in conjunction with a secondary study which investigates recreational impacts from rock climbing on cliff environments (Chapter Two). Study design and collection methods were intentionally similar, however the studies varied by means of site selection (e.g., random vs. random-target; McCune, Grace, \& Urban, 2002). In addition, this study explicitly investigates cliff faces across several cliff-forming sandstone members, whereas the recreational impacts study is limited to one sandstone type and includes other cliff positions (e.g., top, base). In this report, we only analyzed data collected from cliff face, however due to their ecological significance we do include species records from cliff top and base.

\section{Study Design}




\section{Methods}

All study sites were positioned on sandstone cliff faces within in the New River Gorge National River park boundary. We selected study sites by: 1) stratified random sampling to capture and assess recreational impacts from rock climbing, and 2) random site selection from all mapped cliff outcrops. In our first field season, we positioned 112 sites on Nuttall Sandstone cliffs, popular for rock climbing (Williams 2010; K. H. Olcott 2011a). We used 80 experimental sites from previously established rock climbs and 32 control sites deemed suitable for and characteristic of rock climbing but on cliffs with no history of climbing (McMillan \& Larson 2002). All sites were: a) greater than 12 meters in height; b) without excessive amounts of loose rock; c) absent of annual water seeps; and d) with an overall cliff angle $>60^{\circ}$ (Larson, Matthes, and Kelly 2000; Kuntz and Larson 2006b; Kuntz and Larson 2006a). We stratified climbed sites based on rock climb difficulty (e.g. cliff structure), use intensity (e.g. disturbance), and gorge side (e.g. cliff aspect). We randomly selected control sites from a pool of cliffs suitable for climbing and stratified by estimated difficulty and gorge side. All control sites were: a) located $>30 \mathrm{~m}$ from established rock climbs; b) exhibited no visible presence of use (e.g., climbing chalk, bolts, associated gear, trails, etc); c) not described in any local climbing guidebooks (Cater 1995; Thompson 1997; Horst 2003; Williams 2010); d) on cliffs greater than $7 \mathrm{~m}$ wide; e) and were deemed appropriate for climbing by the first author and a local climber (McMillan and Larson 2002).

In the following field season (2011), we randomly selected cliff sites positioned on four cliff forming sandstone groups: Nuttall, Guyandot, Raleigh, and Pineville (Figure 3.1). Because cliffs are poorly represented on most maps and emerge intermittently along the gorge slopes, we used a GIS to identify potential cliff sites. Using a high resolution $\left(0.3 \mathrm{~m}^{2}\right)$ LiDAR (Light Detection and Ranging) model, we interpolated slope by calculating the difference in elevation between pixel values (Appendix Figure 3.1). We then identified macro-site transects starting at the gorge rim trending downslope where each transect intersected with at least three mapped cliff bands. We randomly selected five macro-site transects from each gorge slope using a random number generator and distance along the gorge. We verified the presence and accuracy of modeled cliffs in the field by ground-truthing. Lastly, we identified and digitized cliff sections by sandstone unit by overlaying geologic polylines from "Preliminary Contact Projections Based on West Virginia Geological and Economic Survey Coal Bed Mapping Program Structure and Preliminary Sedimentary Thicknesses" produced by the West Virginia Geological and Economic Survey (G.H. McCollough, personal communication, August 1, 2011).

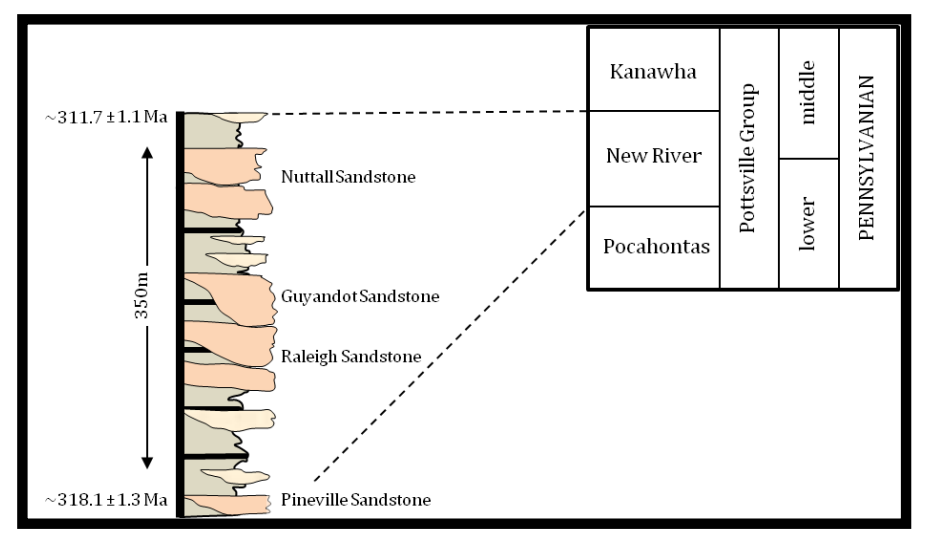

Figure 3.1: Generalized stratigraphic column, redrawn from Korus (2002) 
All cliffs sampled met predetermined criteria including a) on sandstone, b) greater than $8 \mathrm{~m}$ in height, and c) an overall cliff angle no less than $60^{\circ}$ from horizontal. To capture all cliff types, (in contrast to sampling in the 2010 season) we did not consider the following criteria in selecting sites: a) excessive amounts of loose rock, b) annual water seeps, c) presence of use, d) listed in climbing guide books, e) width, or f) distance from human facilities.

Field data were collected between April and September 2010 and 2011. At each site, we recorded cliff height to the nearest $0.5 \mathrm{~m}$ using a weighted rope marked at $1 \mathrm{~m}$ increments, approximate canopy height, cliff face aspect, overall cliff angle (e.g. slope) to the nearest degree using a Johnson Professional Angle Locator, and GPS location. We verified and corrected GPS location in a GIS to an accuracy of $3 \mathrm{~m}$. For each cliff site, we tallied the frequency of macrotopographic features, such as roofs and ledges $(>1 \mathrm{~m})$ or large cracks systems $(>10 \mathrm{~cm})$. We recorded outcrop competency, a geologic measurement affected by mineralogical composition, weathering, cementation, jointing, and block stability (Figure 3.2; K. H. Olcott, 2011a). Given the extensive land use history in the gorge (e.g., mining, railways, transportation), we noted if the cliff face appeared manmade (Appendix Figure 3.2).

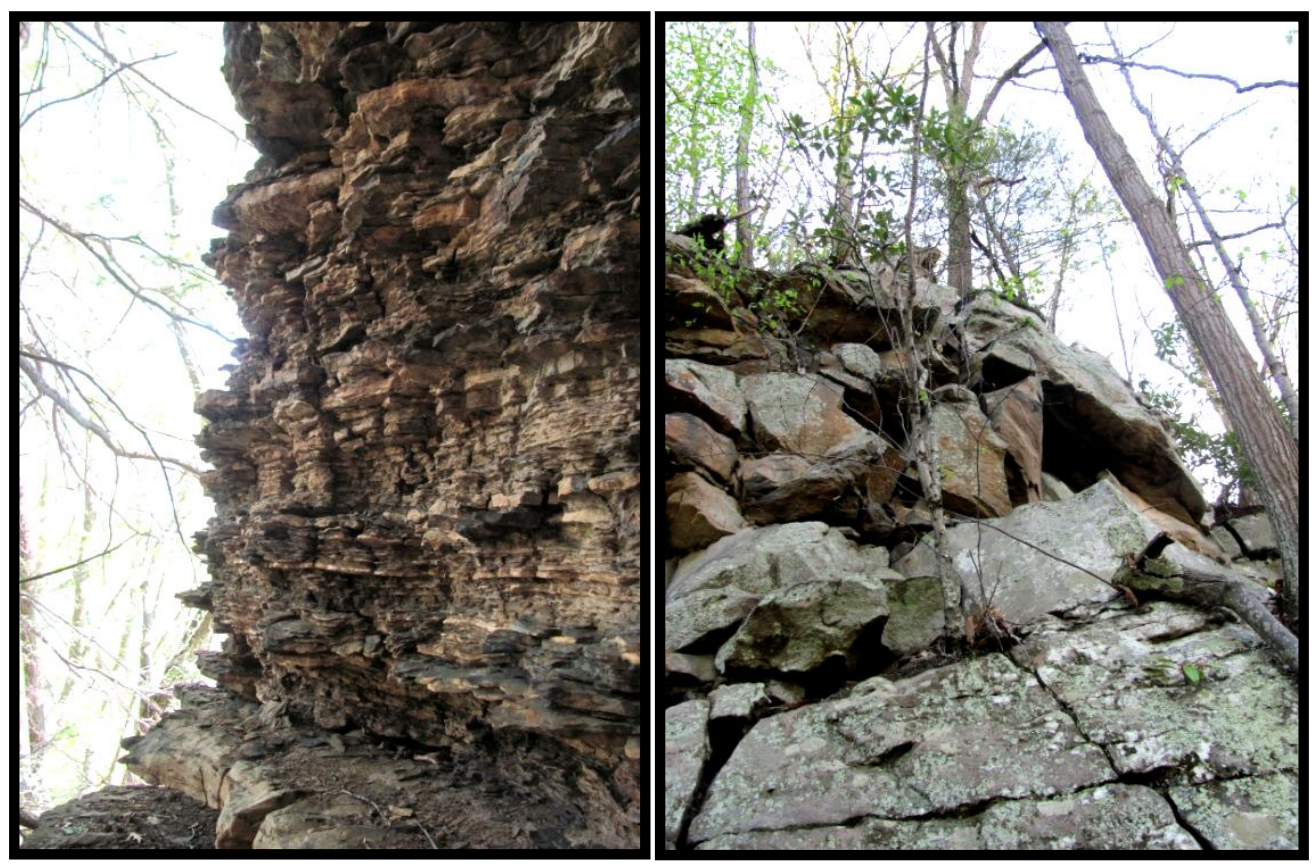

Figure 3.2: Examples of geologically incompetent cliffs

All cliff face transects were approximately vertical following the plumb line of our rappel cords (Figure 3.3). On recreational impact sites, transects were moved according to the direction of the climbing route. A $2 \mathrm{~m}$-wide belt transect was centered over the cliff face to record the presence and frequency of vascular plants along the entire cliff height. Unknown vascular specimens were collected and preserved in a plant press for identification by the first author or specialists at a later date (Jim Vanderhorst, Brian Streets, Elizabeth Byers, and Donna Ford-Werntz). Within the transect, we stationed $1 \mathrm{~m}^{2}$ quadrats at six meter intervals to record finer details of cliff structure and nonvascular and lichen life forms (Figure 3.4). We placed a minimum of two and maximum of five quadrats within each cliff transect, depending on the height of the cliff. We sampled nonvascular and lichen richness, cover, quadrat height, surface roughness, and microtopographic frequency, volume, and area. Quadrats were segmented into $50 \times 50 \mathrm{~cm}$ grids to help estimate 
percent cover of non-vascular plants. We estimated percent cover using methods described in McCune, Grace, \& Urban (2002), where cover classes were distributed along an arcsine square root curve: $<1,1-5,5-25,25-50,50-75,75-95$, and 95-100\%. Given the difficulty of identifying lichen and bryophytes in the field, we sampled unknown specimens and delivered them to specialists Don Flenniken and Susan Studlar for laboratory identification. When a suitable specimen was not available, a sample was collected from outside of the quadrat most closely resembling the original specimen.

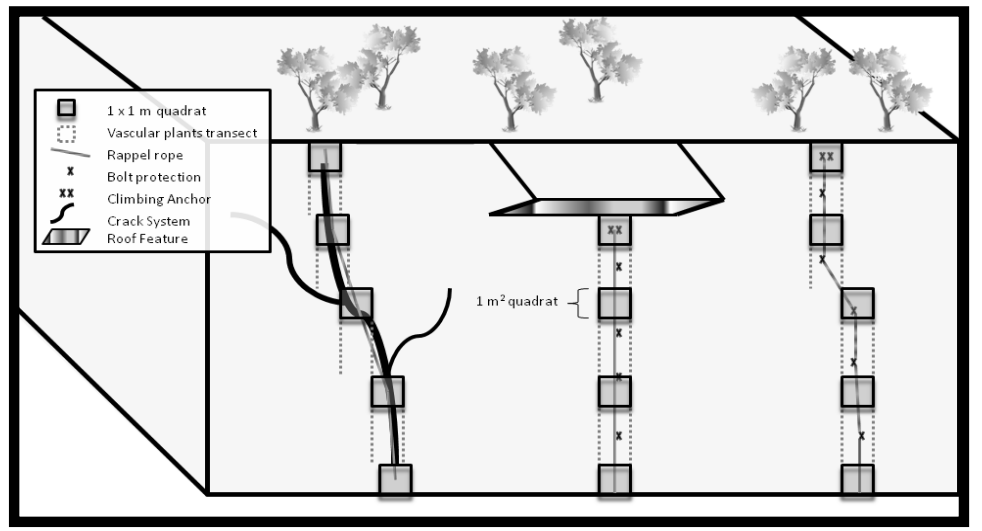

Figure 3.3: Study design

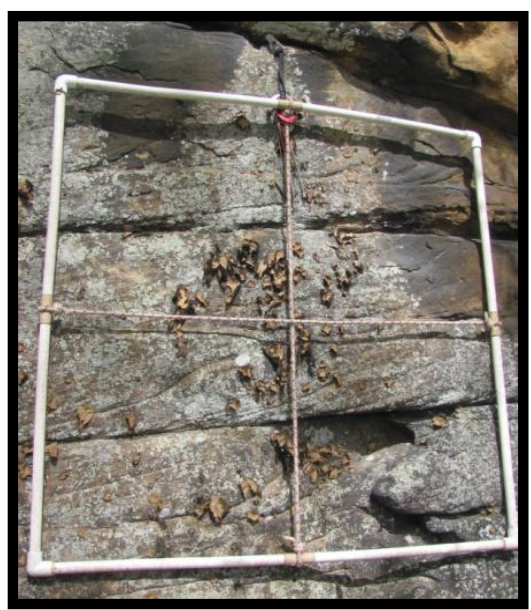

Figure 3.4: A $1 \mathrm{~m} 2$ quadrat positioned on cliff face

\section{Findings}

We sampled 148 sites on sandstone cliff faces in the northern section of the New River Gorge, between Keeneys Creek and the Hawks Nest Damn (Figure 3.5). Sites were positioned on 84 pristine and two manmade cliff sectors. We sampled approximately 5,738 $\mathrm{m}^{2}$ of cliff face, with 552 $1 \mathrm{~m}^{2}$ quadrats. Given the dual study designs, the vast majority of sites were located on Nuttall Sandstone cliffs (Table 3.1). 


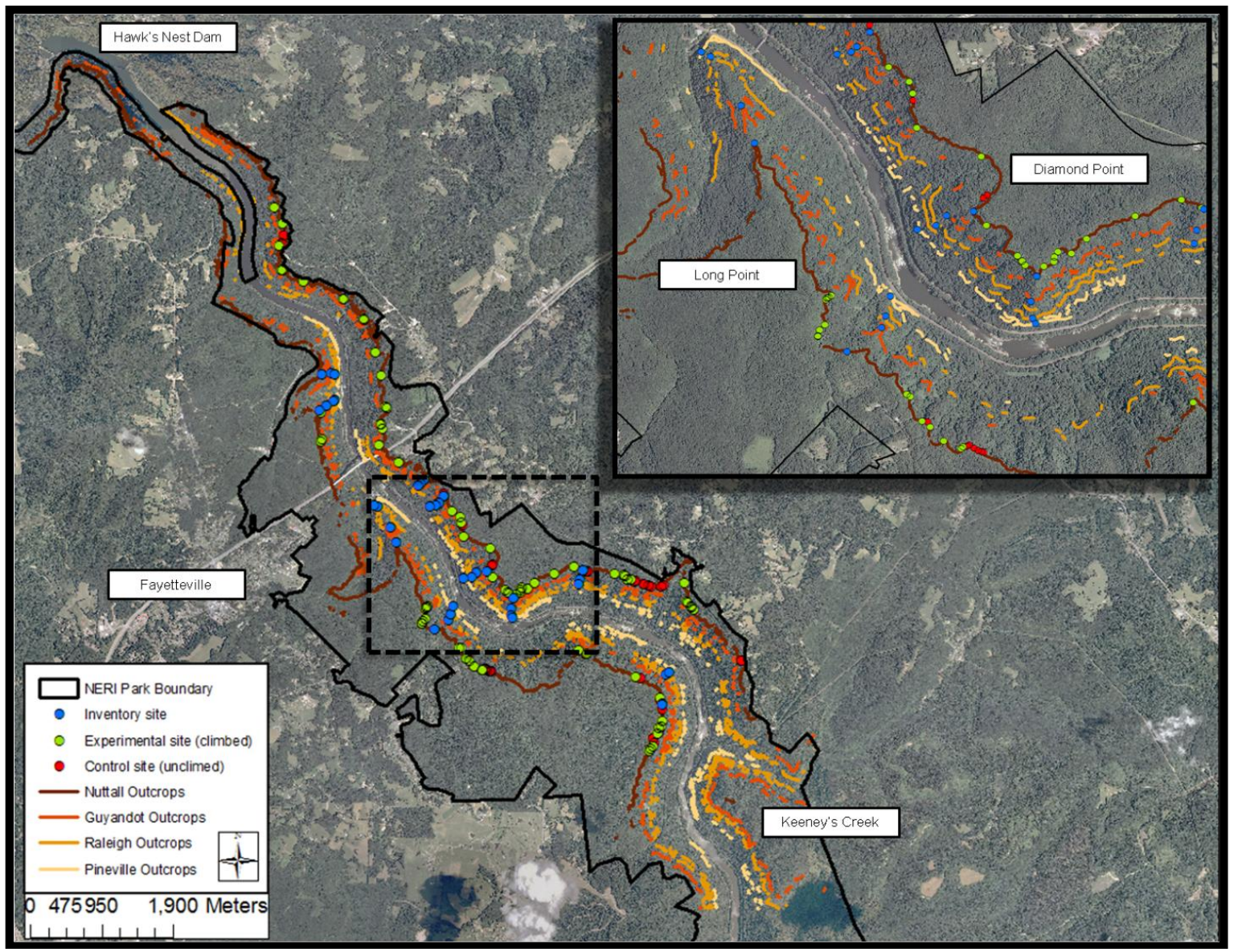

Figure 3.5: Digitized cliff outcrops by geology with study sites. Legend: Black polygon is the NERI park boundary. Nodal points are study sites, where blue are randomly selected inventory sites, green are established rock climbs (experimental sites), and red are unclimbed cliffs (control sites). Polylines are clifflines, where Nuttall = brown, Guyandot $=$ dark orange, Raleigh = orange, and Pineville = light orange.

\begin{tabular}{crrr}
\hline \hline Cliff Type & Number of sites & Area sampled (m²) & \# quadrats \\
\hline All & 148 & 5,738 & 552 \\
Nuttall & $122^{*}$ & 5,098 & 479 \\
Guyandot & 9 & 211 & 25 \\
Raleigh & 10 & 221 & 25 \\
Pineville & 7 & 108 & 23 \\
\hline
\end{tabular}

Table 3.1: Study area descriptive statistics. ${ }^{*}$ Site selection: climbed: 80; unclimbed: 32; random: 10

\section{Spatial Statistics}

Using a GIS, we measured $97 \mathrm{~km}$ of exposed cliff within our study area (Table 3.2). This figure greatly surpasses earlier estimates of $32 \mathrm{~km}$ (Mahan 2004) for the entire gorge. The GIS revealed a high frequency of cliff outcrops throughout the entire study area. The most apparent and continuous cliffs are along the gorge rim, while ridgelines along gorge slopes support many smaller, discontinuous cliff outcrops. We measured a total of 1,114 cliffs ranging in length from $4 \mathrm{~m}$ to 5,007 m (median: $46 \mathrm{~m}$ ). The longest cliff section measured is the appropriately named Endless Wall (5 km), located on the eastern gorge slopes adjacent to Lansing, West Virginia. Other notable 
cliffs of length are South Nuttall $(2.8 \mathrm{~km})$, located on western gorge slopes south of the Kaymoor Mines and an unnamed Nuttall Sandstone cliff are located at the northern extent of the park boundary near the Hawks Nest Dam $(1.8 \mathrm{~km})$. Due to limitations in a GIS, we were unable to accurately assign cliff height to our measured cliff bands, but ground-truthing indicates that our measurements represent outcrops $>8 \mathrm{~m}$ in height.

\begin{tabular}{crrrrrrr}
\hline \hline Cliff Type & $\mathbf{N}$ & $\overline{\mathbf{x}}$ length (m) & Sum (m) & $\begin{array}{r}\text { Median } \\
\text { (m) }\end{array}$ & Max. (m) & $\begin{array}{r}\text { Percent of } \\
\text { total }\end{array}$ & $\begin{array}{r}\overline{\mathbf{x}} \text { Elevation } \\
\text { (m) }\end{array}$ \\
\hline \hline All & 1114 & $87.0 \pm 209.9$ & 96,925 & 46 & 5,007 & $100.0 \%$ & $\mathrm{n} / \mathrm{a}$ \\
Nuttall & 194 & $195.5 \pm 471.3$ & 37,919 & 61 & 5,007 & $38.1 \%$ & 550.0 \\
Guyandot & 353 & $62.5 \pm 50.1$ & 22,070 & 44 & 310 & $22.8 \%$ & 444.0 \\
Raleigh & 368 & $67.2 \pm 68.6$ & 24,720 & 46 & 452 & $25.5 \%$ & 383.0 \\
Pineville & 199 & $61.4 \pm 64.1$ & 12,216 & 39 & 496 & $12.6 \%$ & 345.0 \\
\hline
\end{tabular}

Table 3.2: Large scale descriptive statistics of cliffs in NERI derived from a GIS

We subdivided cliffs by sandstone type and found that Nuttall cliffs comprise nearly $40 \%$ of all outcrops and are consistently lengthier with several cliffs over $1.5 \mathrm{~km}$ (Figure 3.6). Guyandot and Raleigh Sandstones appear on gorge slopes most frequently, but are highly discontinuous with numerous cliffs $<49 \mathrm{~m}$ in length. Pineville Sandstone cliffs occur sporadically throughout the study area, comprising just over one tenth of all exposed cliffs.

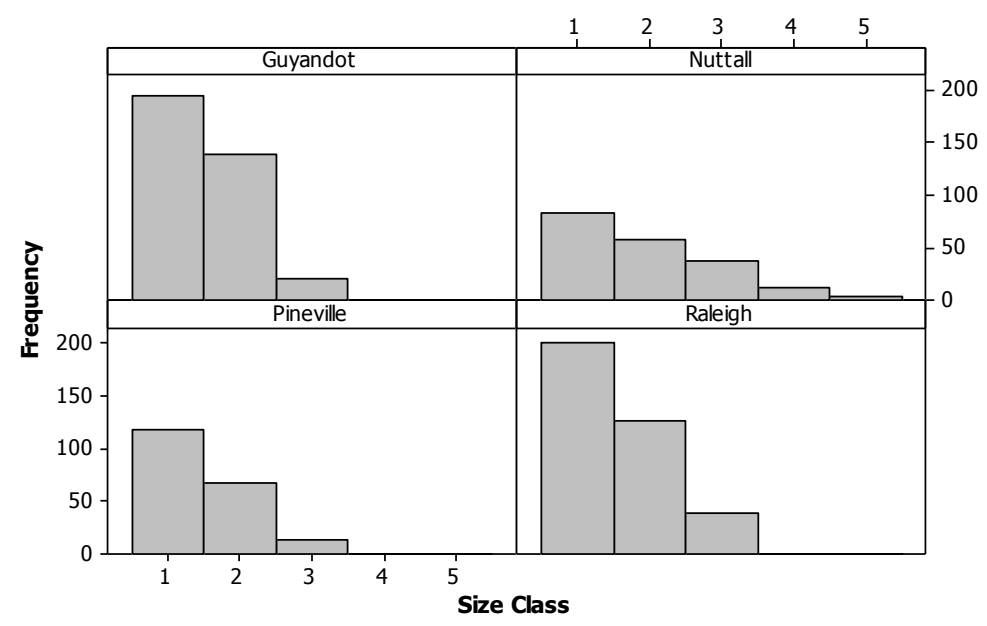

Figure 3.6: Cliff size (length in $\mathrm{m}$ ) derived from a GIS. Size classes consist of: Class $1=<49 \mathrm{~m}$, Class $2=50$ to $149 \mathrm{~m}$, Class $3=150$ to $499 \mathrm{~m}$, Class $4=500$ to $1499 \mathrm{~m}$, Class $5=>1500 \mathrm{~m}$.

\section{Cliff Structure}

We examined all cliff sites by physical structure, derived from field measurements. We first analyzed the Nuttall Sandstone for differences between sites used for rock climbing and those randomly sampled. Only when we found a difference in cliff structure between climbed and randomly selected sites do we present our results as a sub-group. 
Mean cliff height of sampled cliffs is $22 \mathrm{~m}( \pm 7.5)$ and mean slope is $86^{\circ}( \pm 12.0)$, although these attributes vary between cliff members (Figures 3.7 and 3.8). Our physical measurements indicate that Nuttall cliffs are significantly taller than other cliff types, while Guyandot, Raleigh, and Pineville sandstones are less variable $(P<0.01)$. Raleigh Sandstone cliffs are least severe in cliff slope, but contain the greatest numbers of macrotopographic features (Figure 3.9). We observed no differences in mean microtopographic frequency by sandstone type at randomly selected cliffs, but sites sampled for rock climbing on Nuttall cliffs sustained significantly fewer features than all other cliff formers (Figure 3.10; Appendix Table 3.1).

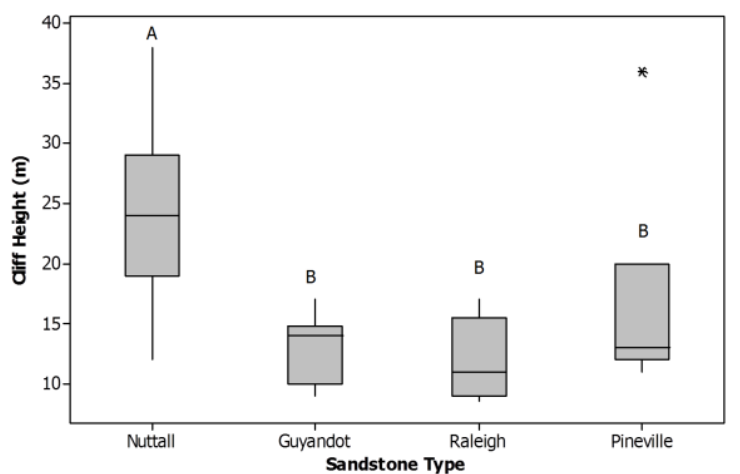

Figure 3.8: Cliff slope in degrees between sandstone types. Box plots that share a letter code are not significantly different at $\alpha=0.05$ (ANOVA)

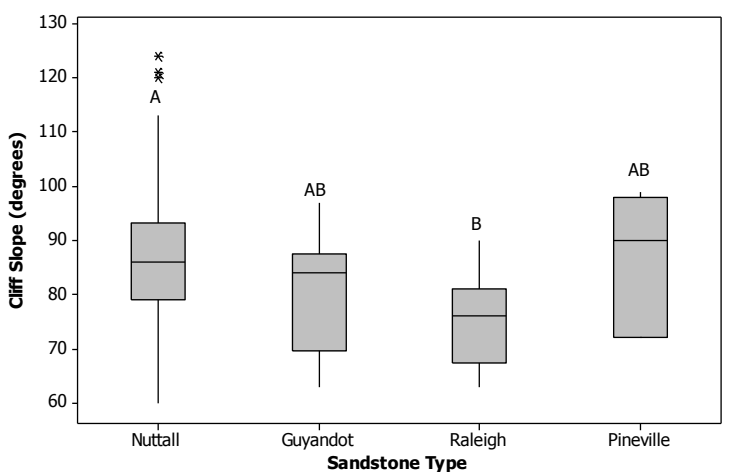

Figure 3.7: Cliff height in meters between sandstone types. Box plots that share a letter code are not significantly different at $\alpha=0.05$ (ANOVA)

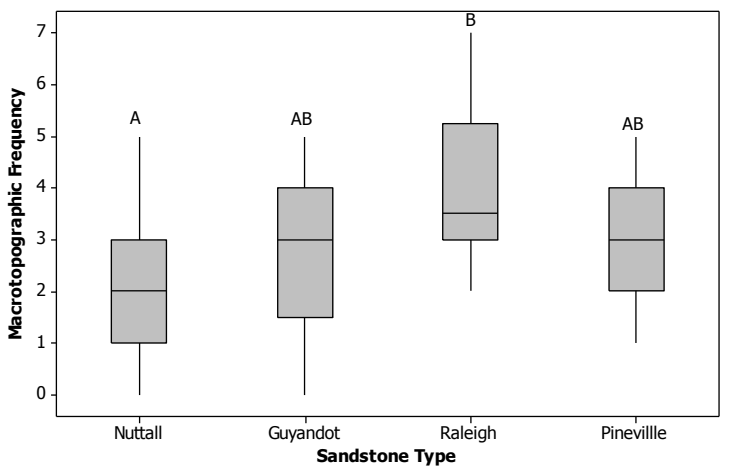

Figure 3.9: Macrotopographic frequency (summed at site level) between sandstone types. Box plots that share a letter code are not significantly different at $\alpha=0.05$ (ANOVA).

We analyzed cliff structure by competency and found that $10 \%$ of all cliffs sampled were classified as geologically $(\mathrm{n}=15)$, but $42 \%$ of randomly selected cliff faces were incompetent. We infer that the later proportion (42\%) is more representative of the level of competency of cliffs in NERI since all of cliffs sampled for recreational impacts were classified as competent, indicating a rock climber aversion to incompetent outcrops. K.H. Olcott (2011a) suggests that competent cliff faces are more appealing to climbers because of the structural integrity, positing that other cliff-forming sandstones may not been widely developed for climbing because they exhibit more structural heterogeneity making them less challenging. Our results demonstrate significant differences in cliff 
structure by competency, supporting Olcott's hypothesis (T-test, $\alpha=0.05$; Table 3.3). Furthermore, cliff outcrop competency generally decreases with gorge elevation (e.g. geologic age): 100\% of Nuttall, $50 \%$ of Guyandot, $56 \%$ of Raleigh, and $14 \%$ of Pineville sites were classified as competent.

\begin{tabular}{crrrrr}
\hline \hline & $\begin{array}{r}\text { Macrotopographic } \\
\text { Frequency }\end{array}$ & $\begin{array}{r}\text { Roof }(>\mathbf{1 m}) \\
\text { Frequency }\end{array}$ & $\begin{array}{r}\text { Ledge }(>\mathbf{1 m}) \\
\text { Frequency }\end{array}$ & $\begin{array}{r}\text { Microtopographic } \\
\text { Frequency }\end{array}$ & Area Edges (cm) \\
\hline \hline Competent & $2.2 \pm 1.4$ & $0.9 \pm 0.8$ & $0.9 \pm 0.9$ & $3.9 \pm 1.6$ & $339.0 \pm 558.0$ \\
Incompetent & $3.9 \pm 1.1$ & $1.5 \pm 0.6$ & $1.8 \pm 0.6$ & $6.6 \pm 1.4$ & $1168.0 \pm 1531.0$ \\
\hline
\end{tabular}

Table 3.3: Cliff face structural measurements. Significantly different $\alpha=0.05$ (T-test) by geologic competency.

\section{Species Observations}

On cliff faces we observed 3,864 different plant specimens from 100 families, 159 genera, and 249 species (Table 3.4). We recorded the greatest diversity of vascular and lichen species, representing $39 \%$ and $38 \%$ of total cliff face species records, respectively. On cliff tops and bases of Nuttall Sandstone cliffs, we recorded an additional 19 families, 53 genera, and 109 species. We report 358 total species recorded in our study. See Appendix Table 3.2 for complete species list.

\begin{tabular}{crrrrrrrr}
\hline \hline & $\begin{array}{r}\text { No. } \\
\text { Observations }\end{array}$ & $\begin{array}{r}\text { No. } \\
\text { species }\end{array}$ & $\begin{array}{r}\text { No. } \\
\text { genera }\end{array}$ & $\begin{array}{r}\text { No. } \\
\text { fam. }\end{array}$ & $\begin{array}{r}\text { Top/Base* } \\
\text { species }\end{array}$ & $\begin{array}{r}\text { Top/Base* } \\
\text { genera }\end{array}$ & $\begin{array}{r}\text { Top/Base* }^{*} \\
\text { families }\end{array}$ & $\begin{array}{r}\text { Overall } \\
\text { species }\end{array}$ \\
\hline \hline Total & 3864 & 249 & 159 & 99 & 109 & 53 & 19 \\
Vascular & 652 & 97 & 67 & 42 & 42 & 24 & 8 \\
Bryophyte & 501 & 56 & 43 & 28 & 33 & 19 & 139 \\
Lichen & 2711 & 96 & 49 & 29 & 34 & 10 & 8 \\
\hline
\end{tabular}

Table 3.4: Number of observations by species, genera, and family. ${ }^{*}=$ Nuttall cliff tops and base from climbing study only

Total species richness is highly variable, ranging from 0 to 49 total species present. Lichens are most prevalent on cliff faces, with on average eight more species than vascular plants or bryophyte (Table 3.5). Cliffs are often considered to be relatively depauperate, but our results indicate that cliff faces are infrequently completely absent of biota, although these results vary significantly by taxon.

\begin{tabular}{|c|c|c|c|c|c|c|}
\hline & $\begin{array}{r}\text { Mean species } \\
\text { richness } \\
\end{array}$ & $\begin{array}{r}\text { Median species } \\
\text { richness } \\
\end{array}$ & $\begin{array}{r}\text { Maximum } \\
\text { species richness } \\
\end{array}$ & $\begin{array}{r}\text { Minimum } \\
\text { species richness } \\
\end{array}$ & $\begin{array}{r}\text { Sites }<2 \\
\text { sp. } \\
\end{array}$ & $\begin{array}{r}\text { Sites }<0 \\
\text { sp. }\end{array}$ \\
\hline Total & $18.4 \pm 9.1$ & 19.0 & $\begin{array}{r}49 \\
(\mathrm{~N} 49)\end{array}$ & $\begin{array}{r}0 \\
(\mathrm{~N} 80, \mathrm{~N} 214)\end{array}$ & $\begin{array}{r}7 \% \\
(n=10)\end{array}$ & $\begin{array}{r}1 \% \\
(\mathrm{n}=2)\end{array}$ \\
\hline Vascular & $4.5 \pm 3.6$ & 4.0 & $\begin{array}{r}19 \\
(\mathrm{~N} 49)\end{array}$ & $\begin{array}{r}0 \\
(\mathrm{~N} 80, \mathrm{~N} 214)\end{array}$ & $\begin{array}{r}34 \% \\
(n=51)\end{array}$ & $\begin{array}{r}13 \% \\
(n=19)\end{array}$ \\
\hline Bryophyte & $2.8 \pm 2.6$ & 2.0 & $\begin{array}{r}10 \\
(\mathrm{~N} 66, \mathrm{~N} 305.01)\end{array}$ & $\begin{array}{r}0 \\
(\mathrm{~N} 80, \mathrm{~N} 214)\end{array}$ & $\begin{array}{r}53 \% \\
(n=54)\end{array}$ & $\begin{array}{r}23 \% \\
(n=34)\end{array}$ \\
\hline Lichen & $11.1 \pm 5.1$ & 11.0 & $\begin{array}{r}24 \\
\text { (N7) }\end{array}$ & $\begin{array}{r}0 \\
(\mathrm{~N} 80, \mathrm{~N} 214)\end{array}$ & $\begin{array}{r}7 \% \\
(n=10)\end{array}$ & $\begin{array}{r}3 \% \\
(n=4)\end{array}$ \\
\hline
\end{tabular}

Table 3.5: Species richness statistics by taxonomic group. Site numbers (e.g., N_\#_) are displayed in association with maximum and minimum species richness values. 
Using a stepwise regression we tested for "structural" (e.g., cliff angle, macrotopographic frequency, microtopographic frequency and volume) and "environmental" (e.g., aspect, elevation) determinants on species richness by taxonomic group (Appendix Figure 3.3). Stepwise regression consistently selected for cliff angle (slope) as the most dominant factor in determining cliff face species richness, while macrotopographic ledge and roof frequency ( $>1 \mathrm{~m})$ are secondary and tertiary drivers. Bryophytes were the only taxa influenced by an environmental variable, aspect. We used predictors revealed in a stepwise regression to build in a multiple linear regression model to account for $38 \%, 36 \%, 18 \%$, and $25 \%$ of total, vascular, bryophyte, and lichen species richness, respectively (Table 3.6; Appendix Figure 3.4).

\begin{tabular}{ccccc}
\hline \hline Response & Predictors & r2 & Adj-r2 & P \\
\hline \hline Total species richness & Cliff angle, ledge frequency, roof frequency & 0.39 & 0.38 & 0.000 \\
Vascular species richness & Cliff angle, ledge frequency & 0.37 & 0.36 & 0.000 \\
Bryophyte species richness & Cliff angle, aspect, roof frequency & 0.20 & 0.18 & 0.000 \\
Lichen species richness & Cliff angle, roof frequency & 0.25 & 0.24 & 0.000 \\
\hline
\end{tabular}

Table 3.6: Results from multiple linear regressions

Some authors hypothesize that cliffs used for rock climbing are inherently different in structure and vegetation, compared to unclimbed cliffs (Filer and Kleinschmidt 1987; Nuzzo 1996; Farris 1998). We tested for differences in vegetation among sites selected for rock climbing (climbed), randomly selected competent cliffs (random), and randomly selected incompetent cliffs (incompetent). Our results show significant differences in vascular species richness and frequency between climbable and incompetent sites (Figure 3.11). We interpret these results as climbers avoiding the most heavily vegetated and structurally heterogeneous cliffs. Our results support Farris (1998) who hypothesis that rock climbers may select cliffs to climb by lack of vegetation.

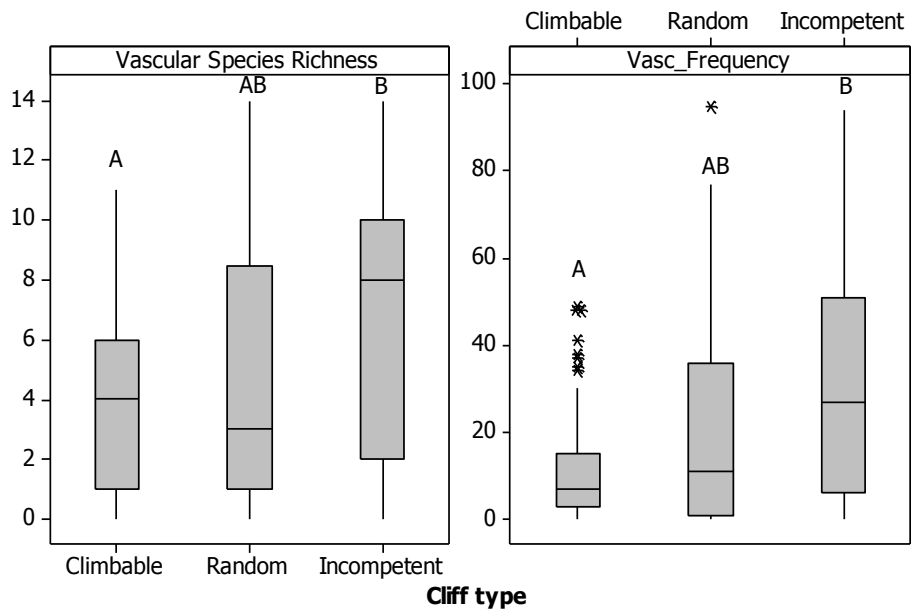

Figure 3.11: Vascular species richness and frequency on cliffs sites selected for rock climbing (climbed), randomly selected competent cliffs (random), and randomly selected incompetent cliffs (incompetent). Box plots that share a letter code are not significantly 


\section{Species Records}

We recorded 97 vascular, 56 bryophyte, and 96 lichen species on cliff faces. Due to the difficulty of sampling, many small crustose and leprariod specimens, several collections were too fragmentary for proper identification. We found that $68 \%, 56 \%$, and $65 \%$ of vascular, lichen, and bryophyte specimens recorded were only found in $\leq 4$ sites, respectively. Table 3.7 outlines the five most common species by taxonomic group (see Appendix Table 3.3 for complete list).

Taxonomic group

Vascular

Lichen

Bryophyte
Top 5 most common

Asplenium montanum

Betula lenta

Acer rubrum

Rhododendron maximum

Rubus sp.

unknown crust**

Lasallia pennsylvanica

Physcia subtilis

Cladonia sp.

Lasallia papulosa

Lepraria lobificans

Leucobryum glaucum

Dicranella heteromalla

Pseudotaxiphyllum elegans

Campylopus tallulensis

Rhabdoweisia crispata

Table 3.7: Five most common species by taxonomic group. ** Note "unknown crust" demonstrates the frequency and difficulty of sampling and identifying crustose lichens, many of which were too fragmentary to determine. It is unlikely that these fragmentary specimens represent new species records.

We recorded five, twelve, and 43 vascular, bryophyte, and lichen species of special interest or rare status, respectively (see Appendix Table 3.4 for complete list). We did not record any of the three plant species of special interest described in the New River Gorge cliff ecology climbing management plan (Corallorrhiza wisteriana Conrad, Woodsia appalachiana T.M.C. Taylor, and Isotria medeoloides (Pursh) Raf.; National Park Service, 2005). In the field we observed more alien plant species on lower, manmade cliffs in proximity to railroad tracks. This observation corresponds with Suiter \& Evans (1999) who suggest that the gorge and the railroad serve as a migratory route through which many weedy plants move into West Virginia from coastal areas. Commonly observed alien species were Paulownia tomentosa (Thunb.) Steud., Lonicera japonica Thunb., and Rosa multiflora Thunb. 


\section{Highlighted Species of Interest}

\section{Vascular Plants}

Danthonia sericea Nutt.

Downy danthonia

Relevance: Present on cliff face, as well as on cliff tops and bases of Nuttall Sandstone cliffs. This species was the $19^{\text {th }}$ most common vascular plant recorded, present in 10 sites (6.7\%). Present in cliff face sites: N28, N42, N44, N57, N62, N204, N206, N211, N212, and N326.01.

Interest: Tracked rare with state ranking 1 (S1): Five or fewer documented occurrences, or very few remaining individuals within the state. Extremely rare and critically imperiled; or because of some factor(s) making it especially vulnerable to extirpation (WVDNR 2012). Also recorded in the nearby Gauley River (Streets and Vanderhorst 2010).

Species Condition: Common to southeastern US, especially along the Coastal Plain, yet uncommon in the Mountains and Interior Low Plateau. Typically in dry woodlands, particularly with sandy soils or dry oak, oak-pine, and pine forests. Flowering AprilJune (Weakley 2010; USDA 2012). We observed all records of this species on or around Nuttall Sandstone cliffs.

Dichanthelium acuminatum (Sw.) Gould \& C.A. Clark ssp. columbianum Tapered rosette grass

See Appendix Figure 3.5 for image

Project relevance: Present on cliff face, as well as on cliff tops and bases of Nuttall Sandstone cliffs. This species was the 33rd most common vascular plant recorded, present in 4 sites (2.7\%). Present in cliff face sites: N73, N204, N212, and N213.

Interest: Not known from the surrounding counties. Tracked rare with state ranking 1 (S1): Five or fewer documented occurrences, or very few remaining individuals within the state. Extremely rare and critically imperiled; or because of some factor(s) making it especially vulnerable to extirpation (WVDNR 2012). Also recorded in the nearby Gauley River (Streets and Vanderhorst 2010).

Species Condition: In northern sites (NY), often found near disturbed areas such as roadsides and open forests or exposed habitat with thin, dry-mesic, rocky soils (Flora of North America Editorial Committee 1993). All species records in the gorge were located on or around Nuttall Sandstone cliffs. We made observations on both gorge slopes, but 3 of 4 were recorded along the Endless Wall. 


\section{Carex appalachica J. Webber \& P.W. Ball}

Appalachian sedge

See Appendix Figure 3.6 for image

Project relevance: Present on cliff bases of Nuttall Sandstone cliffs only. Site N49, N62

Interest: Tracked rare, but possibly more common. State ranking 2 (S2): Six to 20 documented occurrences, or few remaining individuals within the state. Very rare and imperiled; or because of some factor(s) making it vulnerable to extirpation (WVDNR 2012).

Species Condition: Common on dry to mesic deciduous or mixed forests, usually on sandy or rocky soils (Flora of North America Editorial Committee 1993). Specimens were found on east-west facing sites, relatively close to each other $(<1 \mathrm{~km})$ at the base of the cliff know as South Nuttall.

\section{Carex tonsa (Fernald) E.P. Bicknell var. rugosperma (Mack.) Crins Parachute sedge \\ See Appendix Figure 3.7 for image}

Project relevance: Present on cliff face, this species was the $47^{\text {th }}$ most common vascular plant recorded, present in 2 sites (1.3\%). Sites were located on Guyandot and Raleigh Sandstone cliffs. Present on ledges in cliff face sites: N304.02 and N316.03

Interest: Tracked rare. State ranking 2/3 (S2/S3): Six to 20 documented occurrences, or few remaining individuals within the state. Very rare and imperiled; or because of some factor(s) making it vulnerable to extirpation / Twenty-one to 100 documented occurrences. May be somewhat vulnerable to extirpation (WVDNR 2012).

Species Condition: Common to open, dry, acidic, sandy and rocky meadows, roadsides, dunes, ridges, heathlands, savannas, pine, oak, and poplar woodland edges (Flora of North America Editorial Committee 1993; Weakley 2010). We observed this species on east and west facing cliffs. One site (N304.02) was partially disturbed (e.g., manmade), with several invasive species present (Appendix Figure 3.7)

\section{Carex nigromarginata Schwein.}

Black edge sedge

See Appendix Figure 3.8 for image

Project relevance: Present on a Raleigh Sandstone cliff face, this species was found with 15 occurrences on 1 site ( $0.67 \%$ of total). Found on site: N326.03

Interest: Tracked rare. State ranking 3 (S3): Twenty-one to 100 documented occurrences. May be somewhat vulnerable to extirpation (WVDNR 2012). Previously recorded in NERI by Vanderhorst, Jeruck, \& Gawler (2007) 
Species Condition: Common to acidic soils of rocky dry woodlands and forests, thickets or clearings. Occasionally along exposed roadsides and edges. (Flora of North America Editorial Committee 1993; Weakley 2010). We observed several occurrence of this species on a short ( $<14 \mathrm{~m}$ ), low angle, south facing cliff (Appendix Figure 3.8).

\section{Lichens}

\section{Chrysothrix susquehannensis Lendemer \& Elix}

Cliff gold dust lichen

See Appendix Figure 3.9 for image

Project relevance: Present on cliff face, as well as on cliff tops and bases of Nuttall Sandstone cliffs. This species was the $7^{\text {th }}$ most common lichen recorded, present in 70 sites (47\%). Sites were located on all sandstone types.

Interest: Previously unknown in West Virginia; possibly rare and unusual in West Virginia; a newly described species found in one location in Pennsylvania (Lendemer and Elix 2010) and in New Mexico.

Species Condition: Previously only found on the vertical, schist outcrops above the Susquehanna River, Lancaster County, PA. This taxon is distinguished from other Chrysothrix species by its lemon-yellow to greenish color, heaps of granules, production of leconoric and rhizocarpic acids, and ecology (Flenniken 2010). We found that this species is easily recognizable in the field, where field identifications were $96 \%$ correct.

\section{Umbilicaria americana Poelt \& T.H. Nash}

Frosted rock tripe

See Appendix Figure 3.10 for image

Project relevance: Present on cliff faces, this species was the 51th most common lichen recorded. We record four occurrences where one was present within a study site $(0.6 \%)$, but was inventoried on two additional locations. Sites were only located on Nuttall Sandstone. Present in sites: N59, $<5 \mathrm{~m}$ downstream at $25 \mathrm{~m}$ height near N222, $20 \mathrm{~m}$ downstream of a rock climb called "Pink Eye" at approximately $20 \mathrm{~m}$ height, and near the rock climb name "Fantasy Face" at approximately $15 \mathrm{~m}$ height.

Interest: Rare in West Virginia; only 2 previous records by Fred Gray (1930s); previously thought to be extirpated (Flenniken 2010).

Species Condition: A northern species of New England and Canada. Upper thallus is gray-white with the appearance of white dusting, while the lower surface is black velvet-like. Brodo, Sharnoff, \& Sharnoff (2001) indicate that this species is common on steep granitic cliff faces, usually in relatively protected or shaded sites. Our records indicate that in NERI this species is found on exposed, vertical-slightly overhanging Nuttall Sandstone cliffs. 


\section{Chrysothrix insulizans R.C. Harris \& Ladd}

Island gold dust lichen

See Appendix Figure 3.11 for image

Project relevance: Present on cliff faces, as well as on cliff tops and bases of Nuttall Sandstone cliffs. This species was the $30^{\text {th }}$ most common lichen recorded, present in 14 sites (9.4\%). Found predominantly on Nuttall Sandstone cliffs, with one occurrence on the Raleigh Sandstone. Present in sites: N7, N11, N14, N24, N39, N68, N69, N79, N206, N212, N319.01, N326.01, 326.03, N329.01

Interest: Apparently rare and unusual in West Virginia; known from 1 additional county; a newly described species in Harris \& Ladd (2008). Discovered in the adjacent Gauley River (Vanderhorst et al. 2010)

Species Condition: Originally described from the Ozark Region in the southeastern US. Has been found on sandstone on several eastern locations, although probably not common (Harris and Ladd 2008; Flenniken 2010). We made numerous observations of this species in the field at the very base of cliffs $(<1 \mathrm{~m})$, especially under roofs. In many instances, we did not capture $C$. insulizans because our study deign dictated that the lowest quadrat be placed $1 \mathrm{~m}$ above ground level.

\section{Cystocoleus ebeneus (Dillwyn) Thwaites}

Rock gossamer

See Appendix Figure 3.12 for image

Project relevance: Present on Nuttall Sandstone cliff faces, found in only 1 site: N225

Interest: Rare and unusual in West Virginia; known from only a few sites in eastern US.

Species Condition: Field observations indicate that this species is abundant at the site where it was sampled, growing with E. hutchinsiae. Found at the base of a north-facing cliff under dark, closed canopy.

\section{Enterographa hutchinsiae (Leight.) A. Massal.}

Rock script (lichen)

Project relevance: Present on Nuttall Sandstone cliff faces, found in only 1 site: N225.

Interest: Rare and unusual; known from only a few sites in eastern US; grows on sandstone.

Species Condition: Identified sample was found at the base of a north-facing cliff under dark, closed canopy. Sampled with $C$. ebeneus. Field observations indicate that this 
species may possibly be present in N201, N71, N203, but these specimens were too fragmentary to determine (Flenniken 2010).

\section{Bryophytes}

\section{Dicranum condensatum Hedw.}

Condensed fork-moss

See Appendix Figure 3.13 for image

Project relevance: Present on Nuttall Sandstone cliff tops. We made two observations of this unusual bryophyte species in two sites: N58, N222. Note ecology in Appendix Figure 3.13 .

Interest: Rare to West Virginia; State record previously recorded in NERI by Vanderhorst, Jeuck, and Gawler (2007).

Species Condition: A Coastal Plain species flourishing on dry sandy ridges (as in Red River Gorge of KY; (Flora of North America Editorial Committee 1993). We recorded this species less than $1 \mathrm{~m}$ from cliff edge, growing on soil on exposed east facing cliff tops.

\section{Brothera leana (Sull.) Müll. Hal.}

Brothera moss

Project relevance: Present on Nuttall Sandstone cliff faces and tops. This species was the $13^{\text {th }}$ most common bryophyte observed on cliff faces, with records in 8 sites. Found on cliff face sites: N10, N16, N18, N42, N58, N200, N204, N206

Interest: Relatively rare in eastern North America \& in West Virginia (not represented in Studlar (2002) West Virginia Checklist)

Species Condition: Found on humic or peaty soil, rocks, especially sandstone bluffs. (Flora of North America Editorial Committee 1993). Studlar (2011) suggest it is often found on moist sandstone ledges and caves. Species records only occur on Nuttall Sandstone. Observations were often very small $\left(<5 \%\right.$ of $1 \mathrm{~m}^{2}$ quadrat) or hidden within other samples.

\section{Andreaea rothii F.Weber \& D. Mohr}

Dusky rock-moss

See Appendix Figure 3.14 for image

Project relevance: Present on sandstone cliff faces and Nuttall Sandstone cliff tops. This species was the $7^{\text {th }}$ most common bryophyte observed on cliff faces, with records in 12 sites. Found on cliff face sites: N12, N25, N53, N56, N62, N66, N73, N204, N207, N212, N218, N326.01 
Interest: Not common in West Virginia, except in suitable microhabitats (seepy siliceous cliffs); a northern species found in North America, Europe, and China. Recorded in the nearby Gauley River (Vanderhorst et al. 2010).

Species Condition: Characteristic of seepy non-calcareous cliffs and boulders (Flora of North America Editorial Committee 1993). We only found this specimen on Nuttall Sandstone cliff faces, often in damp areas shaded by Rhododendron sp. (Appendix Figure 3.14)

\section{Campylopus tallulensis Sull. \& Lesq.}

Upland swan-neck moss

Project relevance: Present on cliff faces as well as Nuttall Sandstone cliff bases and tops. This species was the $4^{\text {th }}$ most common bryophyte observed on cliff faces, with 47 records in 40 sites (37\%).

Interest: Uncommon except on sandstone ridgetops in Appalachians; uncommon in West Virginia (not in Studlar (2002) checklist), but recorded from river rocks in the nearby Gauley River NRA (Vanderhorst et al. 2010)

Species Condition: Found on acidic rocks and exposed boulders. Infrequently on soil open woods (Flora of North America Editorial Committee 1993). We observed several records on Nuttall Sandstone cliff faces, as well as additional records on Guyandot, Raleigh, and Pineville sandstones. Observations were often very small $\left(<5 \%\right.$ of $1 \mathrm{~m}^{2}$ quadrat).

\section{Dicranum spurium Hedw.}

Rusty Fork-moss

See Appendix Figure 3.15 for image

Project relevance: Present on Nuttall Sandstone cliff tops. We made four observations of this bryophyte species at two sites: N226 and N228

Interest: Uncommon in West Virginia with only 2 collections reported in the WV checklist (Studlar 2002). Recorded from cliff top Pinus virginiana forests at nearby Gauley River NRA (Vanderhorst et al. 2010).

Species Condition: Found on sandy soils, logs, acidic rock, or on organic matter on top of exposed cliff outcrops, often in pine woods (Flora of North America Editorial Committee 1993). We recorded this species on soils and organic matter on Nuttall Sandstone cliff tops with $<3 \mathrm{~m}$ of cliff edge. Specimens were found on the western gorge rim at cliffs names Upper Kaymoor and South Nuttall. 


\section{Cephaloziella spinicaulis Douin}

Spiney-stem Threadwort

Project relevance: Present on Nuttall Sandstone cliff faces, bases and tops. We made one observations of this liverwort at N40 (face), N26 (top), and N8 (base).

Interest: Uncommon; no collections recorded in West Virginia Checklist (Studlar 2002)

Species Condition: A southern liverwort occasional in Appalachians. Observations were often small (5-25\% of $1 \mathrm{~m} 2$ quadrat).

\section{Future Work}

This report represents many of our preliminary findings from our research on cliff environments in NERI. To fulfill our study objectives, we intend to identify species communities and associations in NERI using various ordination techniques. Using our study as a baseline, we will make recommendations for and establish research protocols for utilization of selected study sites as permanent research plots. Lastly, we recommend that additional species inventories be performed by targeting areas underrepresented in our study, such as annual-semiannual wet or manmade cliffs as well as boulder resources. 


\section{CHAPTER FOUR}

\section{Project Summary and Management Recommendations}

The cliff resources in the New River Gorge are locally, regionally, and nationally significant. The research presented here contributes to our understanding of their scope, structural diversity, associated biota, and variability in rock climber use and impacts. In this chapter we outline some of our significant findings as well as management recommendations. We suggest that these findings be collated with those of K.H. Olcott (2011a) and D.K. Olcott (2011b) to develop a comprehensive view of cliff resources in NERI.

Our GIS and field measurements show significant variability in outcrop structure and extent between cliff forming sandstone units in NERI. Cliff angle and competency (e.g. topographic heterogeneity) as well as other environmental drivers (e.g., elevation) moderate biological composition and frequency; low angle, structurally incompetent cliffs sustain the greatest plant diversity. Management could focus on these cliffs to maintain the highest species diversity, however since incompetent cliffs are less desirable for use by climbers, they are thus less likely to be impacted. We suggest that several of our study sites be used for permanent ecological plots as a baseline to monitor changes in these ecosystems. One criterion would be to monitor for the continued presence and health of rare species, including: Danthonia sericea, Dichanthelium acuminatum ssp. columbianum, Chrysothrix susquehannensis, Umbilicaria americana, Dicranum condensatum, and Brothera leana. Some species such as C. susquehannensis are new observations and appear unique to NERI, but are in fact abundant and at less risk of extirpation than previously thought. Others such as D. acuminatum ssp. columbianum, U. americana, and D. condensatum are infrequently observed and of special interest at a state level, indicating they may require special treatment. Permanent plots that monitor for and limit access to rare species are recommended. Since many species of special interest were observed on inaccessible or unused sites, emphasis should be placed on educating user groups to avoid accessing and degrading rare plants and their habitat. Furthermore, we recommend establishing permanent plots on sites across a gradient of aspects, sandstone types, cliff structure, and use intensity classes to monitor the breadth of cliff resources in NERI.

Our results show that sites selected for rock climbing are significantly different in structure and vegetation, representing a subset of all cliffs in NERI. Sites desirable for rock climbing are geologically competent, less heterogeneous in cliff face topography, and inherently sustain significantly fewer vascular species and lower abundance as compared to randomly selected cliffs. These results demonstrate that climbers select specific sites for use, which may narrow the focus for management to sites suitable for climbing. While we cannot extrapolate the total area of competent cliff available or desirable for climbing in NERI, we suspect that the expansion of climbing outside of the Nuttall Sandstone would be minimal given the general incompetency of other cliff formers and their general inaccessibility. We recommend that park management monitors the expansion of climbing along the Nuttall Sandstone, paying particular attention to the new development of cliffs that are low angle and topographically heterogeneous. 
Of competent cliffs, our study provides evidence that impacts caused by climbers are moderated by climb difficulty, use intensity, and occasionally, climb style. Our results demonstrate that a presence/absence view of disturbance to cliffs may limit understanding of recreational impacts on plant communities. Climb difficulty (e.g., cliff structure) and use intensity are clear predictors of diversity and can be used to guide management. From an ecological perspective, the variability in recreational impacts suggests that wholesale closures of climbable cliffs may be unnecessary. Closures of moderate to heavily used areas is not recommended, since users tend to respond by moving to previously less or undisturbed environments (Jim 1989). Interestingly, our results draw attention to low-moderate use sites which appear to maximize cliff face species richness. To maintain this diversity, we encourage managers to work with the climbing community to maintain a low-use profile at these sites. Furthermore, low angle, topographically heterogeneous, competent cliffs are the most susceptible to maximum species loss due to use. Managers may consider limiting the future development of cliffs characteristic of easy and moderate level climbs. Expert level climbs, because of their structure, inherently harbor fewer species, are thus less at risk of disturbance and therefore may be more appropriate for climbing use. It is suggested that future management decisions consider climb difficulty and potential popularity (e.g., quality and accessibility) in developing and implementing a new management plan.

Of all cliff positions, the cliff base is most consistently impacted, regardless of variables tested here. Since beginner level climbs regularly sustain the greatest impacts to cliff base, management may focus finite resources on these climbs, effectively mitigating the largest deleterious effects to cliff environments. Our field observations indicate that the majority of climbs have trails that traverse the cliff base, which are likely the cause of many demonstrable impacts. For management, we recommend that trails be rerouted away from cliff base, which will reduce impacts at all sites, regardless of popularity. We show that cliff tops are the least disturbed cliff position studied, where impacts are largely confined to a subset of sites: introductory level difficulty (<5.9 YDS), high popularity, traditional climbs. Since cliff tops are biologically unique, emphasis should be placed on preserving them. We suggest management identify current and future target areas and establish a perimeter to impede greater impacts. Like cliff base, we recommend that trails be rerouted away from cliff top, which will reduce unnecessary impacts at all sites. Since impacts are confined to a subset of climbing, identifying and educating this user group may prove beneficial in limiting impacts.

We recommend that land mangers work collaboratively with local climbers on a grassroots level to educate and properly ensure the management plans are implemented (Attarian 1999; Attarian and Keith 2008). Research demonstrates that recreationists that are more likely to follow to management recommendations are those who are educated and invested in the environmental rational (Jim 1989; Camp and Knight 1998; Baker 1999; Young 1999; McMillan and Larson 2002). By providing stake holders (e.g., climbers, guide services, tourists) with the appropriate level of information and reasoning about management plans, land managers may more effectively limit the degradation of the environment. One way to connect with stakeholders is to add a section to the local climbing guidebook that is dedicated to rare species and preventing recreational impacts to cliff ecosystems (Williams 2010).

The use of climbing anchors have been widely debated because of concerns about preserving wild spaces and impacts to a viewshed (Baker 1999; Grijalva et al. 2002; Jones and Hollenhorst 2002; Jones 2004; Murdock 2010). Many authors suggest that anchors may play a beneficial role in preventing impacts, particularly to cliff tops (Walker et al. 2004; Wood, Lawson, and Marion 2006; Attarian and Keith 2008), while one concluded that they lead to increased impacts (D. K. Olcott $2011 \mathrm{~b})$. We found that over two-thirds (68\%) of climbed sites sampled in NERI where equipped 
with permanent bolted anchors. Anchors are always placed on sport climbs but are present on less than half of traditional climbs at NERI. We suspect that anchors placed on traditional climbs are associated with popularity, since $77 \%$ are placed on high and extreme use sites $(n=13)$. Similarly, $76 \%$ of traditional climbs without anchors are classified as low and moderate use $(n=19)$. These results correspond with the NERI Climbing Management Plan and public polling (National Park Service 2005) as well as efforts by local climbers to install anchors on heavily trafficked traditional climbs (K. Parker, personal communication, June 3, 2011).

Our study demonstrates that the presence/absence of anchors results in a varied ecological response by cliff position. We found that sites with anchors that were placed $>2 \mathrm{~m}$ below cliff apex visually sustained more vegetation on the cliff face between the anchors and cliff top while sites without anchors infrequently sustained vegetation in this zone. Our study design did not specifically sample above anchors, prohibiting us from investigating if vegetation above anchors is the result of climbers avoiding the terrain, a difference in habitat, or a function of the two. Nuzzo (1996) however found that $70 \%$ of all plants on cliff faces grew within $3 \mathrm{~m}$ of the cliff top. We observed many fragile umbilicate and foliose lichens near the cliff apex, likely the result of increased light levels. Our results suggest that anchors placed below this potentially sensitive and biologically rich zone may act to preserve vegetation in this area from climbing impacts.

At the cliff base, climbs with anchors sustained a significantly greater median hardened zone length compared to climbs without anchors. These results indicate that climbs in NERI with anchors may be more trafficked than those without, which does not correspond with Murdock (2010), who found in Joshua Tree National Park, California, that fixed anchors are not an important factor in attracting climbers to destinations. Increased hardened zone lengths at the cliff base may be due in part to the convenience of permanent anchors, but climb popularity appears to be a critical factor, since $68 \%(n=30)$ of sites with both anchors and a hardened (compacted) zone are classified as high and extreme use sites, while $70 \%(n=7)$ of sites with anchors and no hardened zone are classified as low and moderate use.

Many authors have discussed permanent anchors in the context of preserving cliff tops, suggesting that anchors may deter climbers from accessing the cliff top, thereby limiting impacts (Walker et al. 2004; Wood, Lawson, and Marion 2006; Attarian and Keith 2008). Due to the infrequency in cliff top disturbance, we were unable to detect any significant differences in vegetation, soils, or hardened zone at sites with or without anchors. The interaction between style, difficulty, and use appears to play a critical role in moderating cliff top impacts. Cliff tops on sport climbs rarely contain a hardened zone (3 of 37). Cliff top impacts are almost always associated with hiker lookouts. These results are inconsistent with D.K. Olcott (2011b), who combined visitor observation and resource impact assessments in NERI and concluded that permanent anchors on sport climbs cause increased impacts on cliff tops including enhanced tree damage. This divergence in findings may be due to Olcott's study design and site selection, which was not specifically designed to capture the influence of permanent anchors on impacts across use intensity or difficulty, but instead employed a targeted approach to disturbed areas. We demonstrate that the presence of anchors are not causal to impacts, but rather disturbance is a function of use intensity, difficulty, style, or other external impacts (e.g., hiking). We found that nearly all sites with a measured hardened zone at cliff tops were popular traditional climbs under grade 5.9 YDS. This trend may be due to the popularity of "top-roping" easier climbs, wherein climbers establish anchor systems on cliff tops, by securing climbing tackle to trees, boulders, and in cracks. This practicestyle of climbing may cause climbers to interact with cliff tops more often and for longer periods than other styles, resulting in greater impacts at these sites. Several popular traditional climbs with recorded impacts also have anchors, but were installed after the first documented ascent where 
sites may have already been hardened (K. Parker, personal communication, June 3, 2011). Since cliff top impacts appear to be limited to a subset of climbs (e.g., popular, traditional climbs under grade 5.9 YDS), our research suggests the installation of permanent anchors may limit deleterious impacts on cliff top environments, in correspondence to the "no top-out" policy described by Walker et al. (2004). We recommend the judicious placement of climbing anchors at moderate to high use sites, specifically placed $>2 \mathrm{~m}$ below cliff top as well as education to discourage climbers from topping out. 


\section{References}

Adams, James, and Jim Chandler. 2003. "Evaluation of LiDAR and Medium Scale Photogrammetry for Detecting Soft-Cliff Coastal Change." The Photogrammetric Record 17 (99): 405-418.

Attarian, Aram. 1999. "Factors Influencing Responsible Rock Climbing Behavior.” Unpublished manuscript, American Alpine Club.

Attarian, Aram, and Jason Keith. 2008. Climbing Managment: A Guide to Climbing Issues and the Development of a Climbing Management Plan. Boulder, CO: Access Fund.

Baker, Beth. 1999. "Controversy Over Use of Rock-Climbing Anchors May Be Missing the Mark." Bioscience 49 (7): 529-529.

Bostick, P.E. 1971. "Vascular Plants of Panola Mountain, Georgia." Castanea (36): 194-209.

Brodo, Irwin, Sylvia D. Sharnoff, and Stephen Sharnoff. 2001. Lichens of North America. New Haven and London: Yale University Press.

Brooks, A.B. 1910. West Virginia Geological Survey: Forestry and Wood Industries. Vol. 5. Morgantown, WV: The Acme Publishing Company.

Camp, Richard, and Richard Knight. 1998. "Effects of Rock Climbing on Cliff Plant Communities at Joshua Tree National Park, California." Conservation Biology 12 (6): 1302-1306.

Carr, Chris. 2007. "Variation in Environmental Impact at Rock Climb Areas in Red River Gorge Geological Area and Adjacent Clifty Wilderness, Daniel Boone National Forest, Kentucky". M.A. Thesis, Cincinnati, OH: University of Cincinnati.

Cater, S. 1995. New River Gorge Rock Climbers' Guidebook. Vol. 1. Fayetteville, WV: King Coal Propaganda Publishing.

Collins, S.L., S.M Glenn, and D.J. Gibson. 1995. "Experimental Analysis of Intermediate Disturbance and Initial Floristic Composition: Decoupling Cause and Effect." Ecology 76 (2): 486-492.

Connell, Joseph. 1978. "Diversity in Tropical Rain Forests and Coral Reefs." Science 199 (4335): 1302-1310.

Connor, Jeff. 1990. “Task Force Findings: Climbing in Rocky Mountain National Park (unpublished Manuscript)". Resource Stewardship Division of Rocky Mountain National Park, Denver CO.

Cordell, H.K. 1999. Outdoor Recreation in American Life: A National Assessment of Demand and Supply Trends. Champaign, IL: Sagamore Publishing.

Cox, Janet, and Douglas Larson. 1993. "Environmental Relations of the Bryophytic and Vascular Components of a Talus Slope Plant Community." Journal of Vegetation Science 4 (4): 553560.

Dial, R., and J. Roughgarden. 1988. "Theory of Marine Communities: The Intermediate Disturbance Hypothesis." Ecology 79: 1412-1424.

Douglass, Andrew E. 1929. "The Secret of the Southwest Solved by Talkative Tree-Rings." National Geographic 56: 736-770.

Englund, K.J., P.L. Johnson, and H.H. Amdt. 1982. “Geology of the New River Gorge, West Virginia.” In New River Symposium Proceedings, 136 - 145. Beckley, WV.

Englund, K.J., E.R. King, F.G. Lesure, and W.J. Perry. 1977. Mineral Resource, Geological, and Geophysical Maps of the New River Gorge Area, Fayette, Raleigh, and Summers Counties, West Virginia. Open-File Report NO. 77-076. U.S. Geologic Survey.

Evert, Ray, and Susan Eichhorn. 2013. Raven Biology of Plants. 8th ed. New York, NY: W.H. Freeman.

Farris, M. 1998. "The Effects of Rock Climbing on the Vegetation of Three Minnesota Cliff Systems." Canadian Journal of Botany 76: 1981-1990.

Filer, J.K, and R.F. Kleinschmidt. 1987. "The Geology of Rock Climbing." Mountain State Geology West Virginia Geological and Economic Survey, Morgantown, West Virginia, United States of America: 10-17. 
Flenniken, Don. 2010. New River Gorge Project; Lichens of Rocky Cliffs (unpublished Manuscript). Wooster, $\mathrm{OH}$.

Flora of North America Editorial Committee. 1993. Flora of North America. 16+ vols. New York and Oxford.

Fortney, R.H., S.L. Stephenson, and H.S. Adams. 1994. Reconnaissance Vegetation Study of the Bluestone, New and Gauley River Gorges. Unpublished report to the National Park Service, Glen Jean, WV.

Gotelli, Nicholas, and Robert Colwell. 2001. "Quantifying Biodiversity: Procedures and Pitfalls in the Measurement and Comparison of Species Richness." Ecology Letters 4 (4): 379-391.

Grafton, W.N., and Claude McGraw. 1982. "Plants and Vegetation of the New River Gorge." In The New River Symposim, 69-74. New River Gorge National River, Beckley, WV: National Park Service.

Graham, Liza, and Richard Knight. 2004. "Multi-Scale Comparisons of Cliff Vegetation in Colorado." Plant Ecology 170: 223-234.

Graydon, Don, and Kurt Hanson. 1997. Mountaineering: The Freedom of the Hills. 6th ed. Seattle, WA: The Mountaineers.

Grijalva, Therese, Robert Berrens, Alok Bohora, Paul Jakus, and Douglass Shaw. 2002. "Valuing the Loss of Rock Climbing Access in Wilderness Areas: A National-Level, Random-Utility Model." Land Economics 78 (1): 103-120.

Hale, Mason. 1979. How to Know the Lichens. 2nd ed. Dubuque, IA: Wm. C. Brown Company Publishers.

Hammitt, William, and David Cole. 1998. Wildland Recreation: Ecology and Managment. New York, NY: John Wiley \& Sons.

Harris, R.C., and D Ladd. 2008. "The Genus Chrysothrix in the Ozark Ecoregion, Including a Preliminary Treatment of Eastern and Central North America." Opuscula Philolichenum 5: 29-42.

Horst, Eric. 2003. Bubba City: A Climber's Guide to the New River Gorge. West Virginia: Horst Enterprises/E2 Publishing.

Jefferson County Open Space. 2006. “Climbing Management Guide”. Jefferson County Open Space, CO.

Jenkins, Tony. 2001. New River Climbing Plan Soils Report. USDA-Natural Resource Conservation Service, Fayette/Raleigh County Soil Survey, Glen Jean, WV.: National Park Service.

Jim, C.Y. 1989. “Visitor Managment in Recreation Areas.” Environmental Conservation 16 (19): 1932.

Jodice, P, K. Pyke, and S. Davidson. 1999. “Climbing and Cliff Ecology.” Science 284: 434.

Jones. 2004. "Evaluating Visual Impacts of Near-View Rock Climbing Scenes." Journal of Park and Recreation Administration 22 (3): 39-49.

Jones, C., and S Hollenhorst. 2002. "Toward a Resolution of the Fixed-Anchors in Wilderness Debate." International Journal of Wilderness 8 (3): 15-20.

Keever, C, Henry Oosting, and Lewis Anderson. 1951. "Plant Succession on Exposed Granite of Rocky Face Mountain, Alexander County, North Carolina." Bulletin of the Torrey Botanical Club (78): 401-421.

Kelly, Peter, E.D. Cook, and Douglas Larson. 1994. “A 1397-yr Tree-ring Chronology of Thuja Occcidentalis from Cliff Faces of the Niagara Escarpment: An Eastern Version of Bristlecone Pine?" Canadian Journal of Forest Research 24: 1049-57.

Kelly, Peter, and Douglas Larson. 1997. "Effects of Rock Climbing on Populations of Presettlement Eastern White Cedar (Thuja Occidentalis) on Cliffs of the Niagara Escarpment, Canada." Conservation Biology 11 (5): 1125-1132. 
Korus, J.T. 2002. "The Lower Pennsylvanian New River Formation, a Non-Marine Record of Glacioeustasy in a Foreland Basin". Unpublish Thesis, Blacksburg, VA: Virginia Polytechnic Institute and State University.

Krajick, K. 1999. "Scientists - and Climbers - Discover Cliff Ecosystems.” Science 283: 1623-1625.

Kuntz, Kathryn, and Douglas Larson. 2006a. "Microtopographic Control of Vascular Plant, Bryophyte, and Lichen Communities on Cliff Faces." Plant Ecology.

- - 2 2006b. "Influences of Microhabitat Constraints and Rock-Climbing Disturbance on CliffFace Vegetation Communities." Conservation Biology 20 (3): 821-832.

Kuss, F.R, A.R. Graefe, and J.J. Vaske. 1990. Visitor Impact Management, Volume 1: A Review of Research. Vol. 1. Washington, D.C.: National Parks and Conservation Association.

Lammers, T.G. 1980. “The Vascular Flora of Starr's Cave State Preserve." Proceedings of the Iowa Academy of Science (87): 148-158.

de Lange, Peter, and David Norton. 2004. "The Ecology and Conservation of Kunzea Sinclairii (myrtaceae), a Naturally Rare Plant of Rhyolitic Rock Outcrops." Biological Conservation 117 (1): 49-59.

Larson, Douglas. 2001. "The Paradox of Great Longevity in a Short-lived Tree Species." Experimental Gerontology 36: 651-673.

Larson, Douglas, and Peter Kelly. 1991. "The Extent of the Old-Growth Thuja Occidentalis on Cliffs of the Niagra Escarpment." Canadian Journal of Botany 69: 1628-1636.

Larson, Douglas, Uta Matthes, and Peter Kelly. 2000. Cliff Ecology: Pattern and Process in Cliff Ecosystems. New York: Cambridge University Press.

Larson, Douglas, Uta Matthes, N.W. Larson, J. A. Gerrath, J.C. Nekolas, G Walker, S. Porembski, and A Charlton. 2000. "Evidence for the Widespread Occurrence of Ancient Forests on Cliffs." Jounal of Biogeography 27: 319 - 331.

Lendemer, J.C., and J.A. Elix. 2010. "Two New Species of Chrysothrix from Eastern North America." Opuscula Philolichenum 9: 51-58.

Mahan, Carolyn. 2004. A Natural Resource Assessment for New River Gorge National River. Technical Report NPS/NER/NRTR-2004/002. Philadelphia, PA: National Park Service.

Marion, J. 1991. Developing a Natural Resource Inventory and Monitoring Program for Visitor Impacts on Recreation Sites: A Procedural Manual. Denver, CO: National Park Service, Natural Resources Publication Office.

- - - 2007. Assessments of Recreation Impacts to Trails and Cliffs in the Potomac Gorge. Blacksburg, VA: USGS Patuxent Wildlife Research Center.

Maxwell, R. S., Peter Clark, Som Bohora, Paul Burns, Allyson Carroll, Sylvie Gewehr, Yu-Hsin Hsueh, et al. 2009. "Dendroclimatology: Reconstructing Climate History from Cliffside Pinus Resinosa on Rattlesnake Mountain, Rumney, New Hampshire, Usa". North American Dendroecological Fieldweek. http://dendrolab.indstate.edu/nadef/2009.htm.

Maxwell, R. S., and R. R. Hicks. 2007. "Rimrock Pine Communities at the New River Gorge National River." Technical Report NPS/NER/NRTR, Fayetteville, WV.

McCune, Bruce, James Grace, and Dean Urban. 2002. Analysis of Ecological Communities. Mjm Software Design.

McDonald, Brian. 1989. Progress Report: Rare Species Cooperative Agreement, New River Gorgenational River, for the Period April, 1988-December, 1989. Elkins, WV: Natural Heritage Program, Division of Natural Resources.

-_- 1998. Rare Plant Surveys of Army Camp (stretchers Neck) and Brooklyn Road South. Elkins, WV: West Virginia Natural Heritage Program; West Virginia Division of Natural Resources.

-—_. 2000a. Survey of Rare Species on Camp Brookside-August, 2000. Elkins, WV: Natural Heritage Program, Division of Natural Resources.

- - 2000b. Survey of Rare Species on Camp Brookside-May, 2000. Elkins, WV: Natural Heritage Program, Division of Natural Resources. 
McDonald, Brian, and Paul Harman. 1989. "Rare Species of the Cunard, Stonecliff and Southside Junction Areas, New River Gorge National River". National Park Service.

McDonald, Brian, and P. Trianosky. 1995. "Assessment of and Management Recommendations for Plant Communities and Rare Species of Camp Brookside, New River Gorge National River." Nongame Wildlife and Natural Heritage Program, Wildlife Resources Section, Division of Natural Resources and The Nature Conservancy.

McMillan, Michele, and Douglas Larson. 2002. "The Effects of Rock Climbing on the Vegetation of the Niagara Escarpment in Southern Ontario, Canada." Conservation Biology 16 (2): 389-398.

Murdock, Erik. 2010. "Perspectives on Rock Climbing Fixed Anchors Through the Lens of Wilderness Act: Social, Legal, and Environmental Implications at Joshua Tree National Park, CA". Doctoral Dissertation, Tuscon, AZ: The University of Arizona.

National Climatic Data Center. 2010. "National Climate Data - Climate Data Online." Climatic Data OnLine (CDO). http://cdo.ncdc.noaa.gov/pls/plclimprod/cdomain.abbrev2id.

National Park Service. 2002. “Obed Wild and Scenic River Final Climbing Management Plan”. United States Department of the Interior / National Park Service. Obed, TN.

- - - 2005. “Climbing Management Plan / Environmental Assessment: New River Gorge National River". United States Department of the Interior / National Park Service, Glen Jean, WV.

- - - 2006. "Newsletter for the New River Gorge National River GMP and the Nuttallburg Implementation Plan". National Park Service, New River Gorge, Glen Jean, WV.

-_ . 2007. "General Management Plan / Environmental Impact Statement: Great Falls Park, VA". United States Department of the Interior / National Park Service. Great Falls, VA.

- - - 2010. "Image of the Mines of the New River Gorge". National Park Service. Glen Jean. WV.

Nuzzo, V. A. 1995. "Effects of Rock Climbing on Cliff Goldenrod (Solidago Sciaphila Steele) in Northwest Illinois." American Midland Naturalist 133: 229-241.

-_- 1996. "Structure of Cliff Vegetation on Exposed Cliffs and the Effect of Rock Climbing." Canadian Journal of Botany 74 (4): 607-617.

Oksanen, Jari. 2012. "Vegan: Ecological Diversity". http://cran.rproject.org/web/packages/vegan/vignettes/diversity-vegan.pdf. Accessed on 03/01/2012.

Oksanen, Jari, Guillaume Blanchet, Roeland Kindt, Pierre Legendre, Peter R. Minchin, R.B. O’Hara, Gavin L. Simpson, Peter Solymos, M. Henry H. Stevens, and Helene Wagner. 2012. "Vegan: Community Ecology Package". R package version 2.0-3. http://cran.rproject.org/web/packages/vegan/vignettes/diversity-vegan.pdf.

Olcott, D.K. 2011b. "Understanding Cliff Use at the New River Gorge National River: Combining Visitor Observations and Resource Impact Assessments." Masters Thesis, West Virginia: West Virginia University, Department of Parks and Recreation. http://gradworks.umi.com/15/01/1501697.html.

Olcott, K. H. 2011a. "What Makes Good Climbing Rock? a Petrographic, Structural, and Mechanical Investigation of the Lower Nuttall Sandstone in the New River Gorge, West Virginia". Masters Thesis, Morgantown, WV: West Virginia University, Department of Geology and Geography.

Oosting, Henry, and Lewis Anderson. 1937. "The Vegetation of a Barefaced Cliff in Western North Carolina." Ecology 18 (2): 280-292.

_-_. 1939. "Plant Succession on Granite Rock in Eastern North Carolina." Botanical Gazette 100: 750-768.

Phillips, V.J.S. 1969. “The Botany of the New River Valley Between Glen Lyn, Virginia and Gauley Bridge". PhD Dissertation, West Virginia: West Virginia University.

Pickett, Stewart, and P.S. White. 1986. The Ecology of Natural Disturbance and Patch Dynamics. San Diego, CA: Academic Press.

Remo, J.W.F. 1999. “Geologic Controls on Mass Movement in the New River Gorge, West Virginia”. M.S. Thesis, Morgantown: West Virginia University. 
Rouse, Carrie D., and Brian McDonald. 1986. Rare Vascular Plant Survey; New River Gorge. Philadelphia, PA: West Virginia Natural Heritage Program.

Rusterholz, Hans-Peter, Stefan Muller, and Bruno Baur. 2004. "Effects of Rock Climbing on Plant Communities on Exposed Limestone Cliffs in the Swiss Jura Mountains." Applied Vegetation Science 7: 35-40.

Saladyga, Tom. 2011. "Land Use and Climate Impacts on Fire Regimes and Forest Regeneration in the Upper Tuul River Watershed, Mongolia". Doctoral Dissertation, West Virginia: West Virginia University.

Sanders, Howard. 1968. "Marine Benthic Diversity: A Comparative Study." The American Naturalist 102 (925): 243-283.

Schuster, Rudy, James Thompson, and William Hammit. 2001. "Rock Climbers' Attitudes Toward Management of Climbing and the Use of Bolts." Environmental Management 28 (3): 403412.

Smiley, D, and C.J. George. 1974. "Photographic Documentation of Lichen Declines in the Shawangunks Mountains of New York." Bryologist 77: 179-187.

Squire, Jefferey. 2003. "Farley Ledge Managment Plan". Western Massachusetts Climbers Coalition. http://www.climbgneiss.org/. Accessed on 03/01/2010.

Streets, Brian, and James Vanderhorst. 2010. Floristic Inventory of Gauley River National Recreation Area, West Virginia. Technical Report NPS/NER/NRTR-2010/149. Philadelphia, Pennsylvania: National Park Service.

Studlar, Susan. 1980. "Trampling Effects on Bryophytes: Trail Surveys and Xxperiments." The Bryologist 83 (3): 301-313.

——- 1983. "Recovery of Trampled Bryophyte Communities Near Mountian Lake, Virginia." Bulletin of the Torrey Botanical Club 110 (1): 1-11.

- - 2002. Annotated Checklist of the Hornworts, Liverworts and Mosses of West Virginia. Elkins, WV: West Virginia Division of Natural Resources.

Studlar, Susan, and Jerry Snider. 1989. "Bryophytes of the Red River Gorge of Kentucky: Floristics and Phytogeography." Castanea 54 (3): 133-152.

Suiter, D.W., and D.K. Evans. 1999. "Vascular Flora and Rare Species of New River Gorge National River, West Virginia." Castanea 64: 23-49.

The Outdoor Foundation. 2011. 2011 Outdoor Recreation Participation Report. Boulder, CO.

Thiel, Hjalmar, and Toby Spribille. 2007. "Lichens and Bryophytes on Shaded Sandstone Outcrops Used for Rock Climbing in the Vacinity of Göttingen (southern Lower Saxon, Germany)." Herzogia 20: 159-177.

Thompson, Rick. 1997. New River Rock. Conifer, CO: Chockstone Press.

Toula, Tim. 2002. Rock " $n$ " Road, 2nd: An Atlas of North American Rock Climbing Areas. Second. Evergreen, CO: Chockstone Press.

Unrau, H.D. 1996. "Special History Study / Historic Context Study: New River Gorge National River, WV". USDA National Park Service. New River Gorge National River. Glen Jean, WV.

Ursic, K.A., N.C. Kenkel, and Douglas Larson. 1997. "Revegetation Dynamics of Cliff Faces in Abandoned Limestone Quarries." Journal of Applied Ecology 34: 289-303.

USDA, NRCS. 2012. "The Plants Database." National Plant Data Team, Greensboro, NC 27401-4901 USA. http://plants.usda.gov.

Vanderhorst. 2001. Plant Communities of the New River Gorge National River, West Virginia: (Northern and Southern Thirds). Glen Jean, WV: National Park Service, New River Gorge National River.

- - - 2003. "Roadless Block Analysis for New River Gorge National River. Final Report". West Virginia Natural Heritage Program. Elkins, W.V. 
Vanderhorst, James Jeuck, and Susan Gawler. 2007. Vegetation Classification and Mapping of New River Gorge National River, West Virginia. Philadelphia, PA: National Park Service. Glen Jean. WV.

Vanderhorst, Brian Streets, Zachary Arcaro, and Susan Gawler. 2010. Vegetation Classification and Mapping of Gauley River National Recreation Area, West Virginia. Technical Report NPS/NER/NRTR-2010/148. Philadelphia, PA: U.S. Department of the Interior National Park Service.

Voller, Joan, and Scott Harrison. 1998. Conservation Biology Principles for Forested Landscapes. British Columbia: University of British Columbia.

Walker, G. E. 1987. "Ecology and Population Biology of Thuja Occidentalis L. in Its Southern Disjunct Range”. PhD Thesis, Knoxville, TN: University of Tennessee.

Walker, Emily Parisher, Peter Smith, David Whitlock, David Kramer, Uta Matthes, and Leslie Morefield. 2004. "Characterization of Plant Community Structure and Abiotic Conditions on Climbed and Unclimbed Cliff Faces in the Obed River Gorge". Technical report submitted to the National Park Service, Obed River Gorge.

Ward, J.W., and J.A. Stanford. 1983. Intermediate-Disturbance Hypothesis: An Explanation for Biotic Diversity Patterns in Lotic Ecosystems. Ann Arbor MI: Ann Arbor Science.

Weakley, Alan. 2010. Flora of the Southern and Mid-Atlantic States (Working Draft). Chapel Hill, NC: University of North Carolina at Chapel Hill.

Weaks, T.E., and M Nowland. 1997. "Lichen and Non-Vascular Flora of New River Gorge National River, West Virginia. Final Report.” National Park Service, New River Gorce, Glen Jean, WV.

White Mountains National Forest. 2008. "Rumney Rocks Climbing Managment Plan". National Forest Service.

Williams, Michael. 2010. New River Gorge Rock Climbs. Silt, CO: Wolverine Publishing.

Wood, K.T., S.R. Lawson, and J.L. Marion. 2006. "Assessing Recreation Impacts to Cliffs in Shenandoah National Park: Integrating Visitor Observation with Trail and Recreation Site Measurements." Journal of Park and Recreation Administration 24 (4): 86-110.

WVDNR. 2012. "Rare, Threatened And Endangered Species In West Virginia." West Virginia Department of Natural Resources. http://www.wvdnr.gov/Wildlife/RareSpecList.shtm. Accessed on 04/01/2012.

Young, Wills. 1999. "Climbing Threatened by Lichens: Smart Scientists Needed to Combat Anticlimbing Hysteria." Climbing Magazine. CO.

Zimmer, Valerie, Brian Collins, Greg Stock, and Nicholas Sitar. 2012. "Rock Fall Dynamics and Deposition: An Integrated Analysis of the 2009 Ahwiyah Point Rock Fall, Yosemite National Park, USA." Earth Surface Processes and Landforms. 


\section{Appendix}

\section{Tables}

\begin{tabular}{crrrrrr}
\hline \hline Anthropogenic Evidence & \multicolumn{2}{c}{ Cliff Base } & \multicolumn{2}{c}{ Cliff Face } & \multicolumn{2}{c}{ Cliff Top } \\
& $\mathrm{n}$ & $\%$ & $\mathrm{n}$ & $\%$ & $\mathrm{n}$ & $\%$ \\
\hline \hline None & 17 & 22 & 43 & 55 & 48 & 62 \\
Tree damage & 12 & 15 & 1 & 1 & 5 & 6 \\
Trash & 14 & 18 & 3 & 4 & 2 & 3 \\
Other & 1 & 1 & 0 & 0 & 4 & 5 \\
Trails & 58 & 74 & - & - & 23 & 29 \\
Lookouts & - & - & - & - & 6 & 8 \\
Chalk & - & - & 32 & 41 & - & - \\
\hline
\end{tabular}

Appendix Table 2. 1: Observations of anthropogenic disturbance at three cliff positions (cliff base, face, and top) 


\begin{tabular}{|c|c|c|c|c|c|c|}
\hline $\begin{array}{c}\text { Grade } \\
\text { Class }\end{array}$ & Site Type & $\mathbf{N}$ & $\begin{array}{l}\text { TOTAL } \\
\text { SR \& IQR }\end{array}$ & $\begin{array}{c}\text { VASCULAR } \\
\text { SR \& IQR }\end{array}$ & $\begin{array}{c}\text { BRYOPHYTE } \\
\text { SR \& IQR }\end{array}$ & $\begin{array}{l}\text { LICHEN } \\
\text { SR \& IQR }\end{array}$ \\
\hline$\stackrel{\stackrel{y}{n}}{\rightleftarrows}$ & $\begin{array}{l}\text { Climbed } \\
\text { Unclimbed }\end{array}$ & 32 & $\begin{array}{c}15.5 \\
10.3 \\
\\
16.4 \\
9.7\end{array}$ & $\begin{array}{l}3.0 \\
5.0 \\
\\
4.0 \\
2.8\end{array}$ & $\begin{array}{l}3.0 \\
4.0 \\
\\
2.0 \\
4.5\end{array}$ & $\begin{array}{l}9.0 \\
5.6 \\
\\
9.9 \\
4.0\end{array}$ \\
\hline 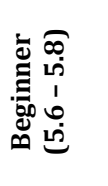 & $\begin{array}{l}\text { Climbed } \\
\text { Unclimbed }\end{array}$ & 17 & $\begin{array}{c}20.6 \\
8.7 \\
\\
24.9 \\
4.0\end{array}$ & $\begin{array}{l}6.0 \\
4.5 \\
\\
7.0 \\
4.8\end{array}$ & $\begin{array}{l}4.0 \\
6.0 \\
\\
5.0 \\
2.0\end{array}$ & $\begin{array}{c}10.4 \\
4.3 \\
\\
12.7 \\
2.4\end{array}$ \\
\hline 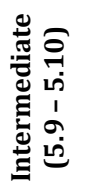 & $\begin{array}{l}\text { Climbed } \\
\text { Unclimbed }\end{array}$ & 22 & $\begin{array}{c}16.0 \\
8.8 \\
\\
17.6 \\
6.2\end{array}$ & $\begin{array}{l}3.0 \\
4.3 \\
\\
4.5 \\
2.8\end{array}$ & $\begin{array}{l}3.5 \\
3.0 \\
\\
2.0 \\
4.3\end{array}$ & $\begin{array}{c}9.1 \\
5.3 \\
\\
10.2 \\
4.3\end{array}$ \\
\hline 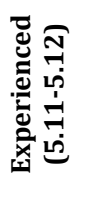 & $\begin{array}{l}\text { Climbed } \\
\text { Unclimbed }\end{array}$ & 20 & $\begin{array}{c}15.6 \\
8.3 \\
\\
17.1 \\
4.5\end{array}$ & $\begin{array}{l}3.5 \\
4.8 \\
\\
3.5 \\
2.0\end{array}$ & $\begin{array}{l}2.0 \\
3.7 \\
\\
\\
2.5 \\
3.5\end{array}$ & $\begin{array}{l}8.5 \\
5.5 \\
\\
9.9 \\
0.9\end{array}$ \\
\hline 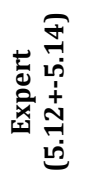 & $\begin{array}{l}\text { Climbed } \\
\text { Unclimbed }\end{array}$ & 20 & $\begin{array}{l}10.0 \\
10.6 \\
8.6 \\
8.5\end{array}$ & $\begin{array}{l}1.0 \\
1.8 \\
\\
1.0 \\
3.8\end{array}$ & $\begin{array}{l}0.5 \\
3.0 \\
0.0 \\
0.8\end{array}$ & $\begin{array}{l}7.3 \\
7.9 \\
\\
6.6 \\
6.5\end{array}$ \\
\hline
\end{tabular}

Appendix Table 2. 2: Median species richness (SR) and interquartile range (IQR) on cliff faces by difficulty and by taxa. No significant differences are observed between difficulty classes and taxonomic groups 


\begin{tabular}{|c|c|c|c|c|c|}
\hline Grade Class & $\mathrm{N}$ & $\begin{array}{l}\text { Median litter depth } \\
(\mathrm{cm}) \text { and IQR }\end{array}$ & & $\begin{array}{l}\text { Median } 0 \text { horizon } \\
\text { depth }(\mathrm{cm}) \text { and IQR }\end{array}$ & \\
\hline $\begin{array}{c}\text { Beginner } \\
(5.6-5.8)\end{array}$ & 25 & $\begin{array}{l}1.7 \\
2.5\end{array}$ & A & $\begin{array}{l}2.7 \\
3.7\end{array}$ & $\mathrm{~A}$ \\
\hline $\begin{array}{c}\text { Intermediate } \\
(5.9-5.10)\end{array}$ & 30 & $\begin{array}{l}2.5 \\
3.1\end{array}$ & A & $\begin{array}{l}2.7 \\
3.0\end{array}$ & A \\
\hline $\begin{array}{c}\text { Experienced } \\
(5.11-5.12)\end{array}$ & 28 & $\begin{array}{l}2.3 \\
2.0\end{array}$ & A & $\begin{array}{l}2.2 \\
3.3\end{array}$ & A \\
\hline $\begin{array}{c}\text { Expert } \\
(5.12+-5.14)\end{array}$ & 28 & $\begin{array}{l}0.7 \\
3.6\end{array}$ & A & $\begin{array}{l}0.3 \\
1.5\end{array}$ & B \\
\hline
\end{tabular}

Appendix Table 2. 3: Cliff base soils depths (median values and IQR) at all site controlled by difficulty. Statistical significance is calculated using Kruskal-Wallis test. Columns that share a letter code are not significantly different from one another at $\alpha$ $=0.05$. 


\begin{tabular}{|c|c|c|c|c|c|c|c|}
\hline & le Class & $\mathbf{N}$ & $\begin{array}{c}\text { Median litter } \\
\text { depth }(\mathrm{cm}) \\
\text { and IQR }\end{array}$ & & $\begin{array}{c}\text { Median O } \\
\text { horizon depth } \\
(\mathrm{cm}) \text { and IQR }\end{array}$ & & $\begin{array}{c}\text { Median } \\
\text { Hardened } \\
\text { Zone length } \\
\text { (m) and } \\
\text { IQR }\end{array}$ \\
\hline$\stackrel{巳}{\vdots}$ & $\begin{array}{l}\text { Climbed } \\
\text { Unclimbed }\end{array}$ & 79 & $\begin{array}{l}1.3 \\
2.7 \\
\\
2.8 \\
2.0\end{array}$ & $\mathrm{P}<0.01$ & $\begin{array}{r}1.7 \\
3.7 \\
\\
2.8 \\
3.1\end{array}$ & $\mathrm{P}<0.05$ & $\begin{array}{l}3.0 \\
6.0 \\
n / a\end{array}$ \\
\hline 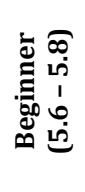 & $\begin{array}{l}\text { Climbed } \\
\text { Unclimbed }\end{array}$ & 17 & $\begin{array}{l}1.7 \\
3.0 \\
2.3 \\
2.0\end{array}$ & $n s$ & $\begin{array}{r}1.7 \\
3.7 \\
\\
3.8 \\
4.6\end{array}$ & $\mathrm{P}<0.01$ & $\begin{array}{l}4.3 \\
6.5 \\
\\
\mathrm{n} / \mathrm{a}\end{array}$ \\
\hline 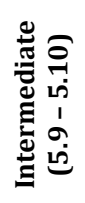 & $\begin{array}{l}\text { Climbed } \\
\text { Unclimbed }\end{array}$ & 22 & $\begin{array}{l}1.3 \\
3.5 \\
\\
3.5 \\
1.0\end{array}$ & $n s$ & $\begin{array}{l}2.1 \\
3.5 \\
\\
3.5 \\
1.9\end{array}$ & $n s$ & $\begin{array}{l}3.8 \\
6.3 \\
\text { n/a }\end{array}$ \\
\hline 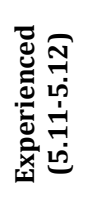 & Climbed & 20 & $\begin{array}{l}2.3 \\
2.6 \\
\\
2.8 \\
2.0\end{array}$ & $n s$ & $\begin{array}{l}1.8 \\
4.0 \\
\\
2.8 \\
2.3\end{array}$ & $n s$ & $\begin{array}{l}2.3 \\
5.0\end{array}$ \\
\hline 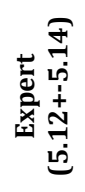 & $\begin{array}{l}\text { Climbed } \\
\text { Unclimbed }\end{array}$ & 20 & $\begin{array}{l}0.4 \\
2.9 \\
\\
2.3 \\
7.3\end{array}$ & $n s$ & $\begin{array}{l}0.3 \\
2.8 \\
\\
0.4 \\
0.7\end{array}$ & $n s$ & $\begin{array}{l}2.8 \\
3.8 \\
\mathrm{n} / \mathrm{a}\end{array}$ \\
\hline
\end{tabular}

Appendix Table 2. 4: Cliff base soils depths and hardened zone lengths (median values and IQR) controlled by difficulty. Statistical significance is calculated using Kruskal-Wallis test between groups within boxes. Groups that share the code "ns" are not significantly different from one another at $\alpha=0.05$. 


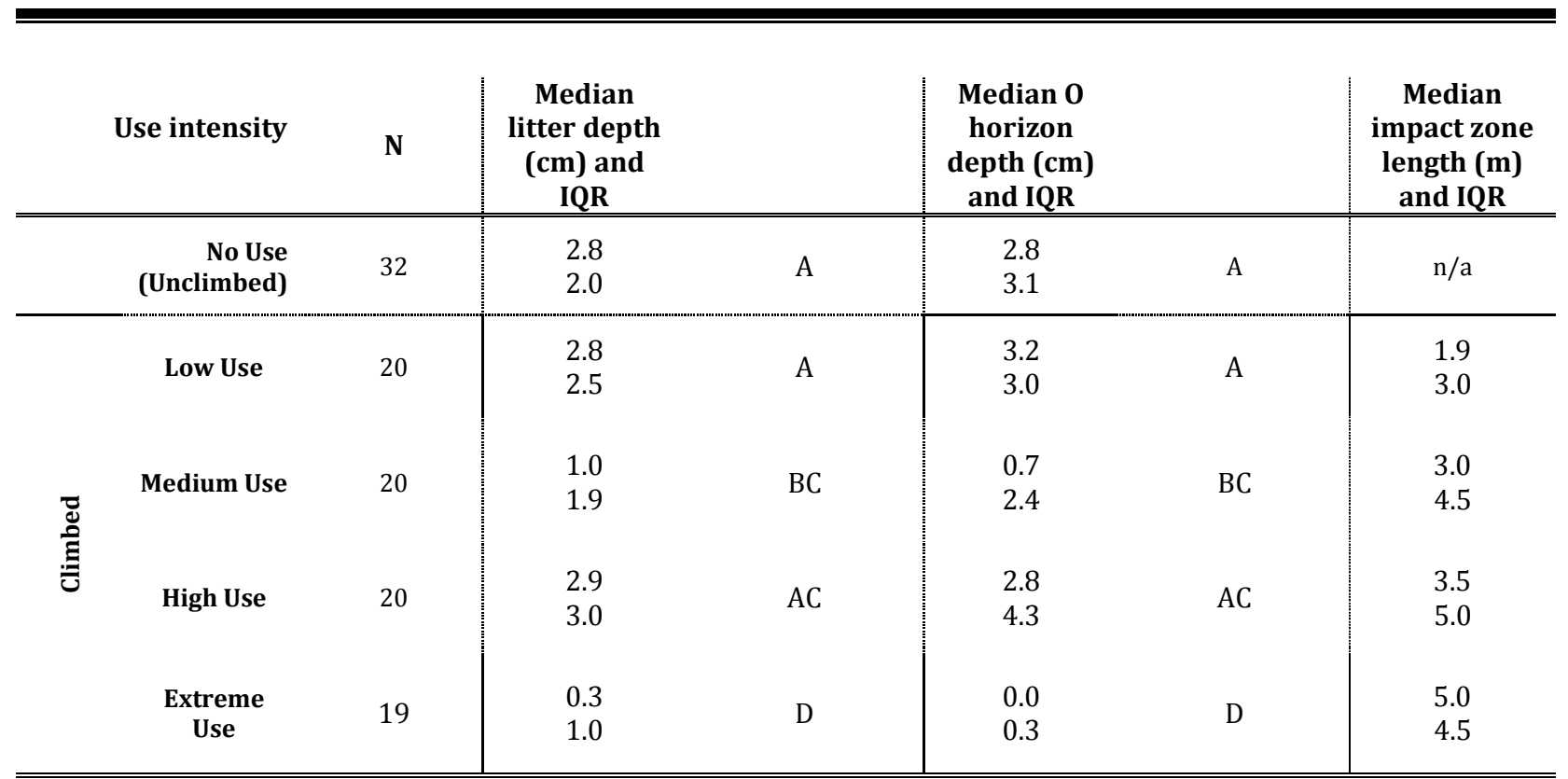

Appendix Table 2. 5: Cliff base soils depths and hardened zone lengths (median values and IQR) at all site controlled by use intensity. Statistical significance is calculated using Kruskal-Wallis test. Columns that share a letter code are not significantly different from one another at $\alpha=0.05$. 


\begin{tabular}{|c|c|c|c|c|c|c|c|c|c|}
\hline \multirow[b]{2}{*}{ Grade Class } & \multirow[b]{2}{*}{$\mathbf{N}$} & \multicolumn{2}{|c|}{ Total } & \multicolumn{2}{|c|}{ Vascular } & \multicolumn{2}{|c|}{ Bryophyte } & \multicolumn{2}{|c|}{ Lichen } \\
\hline & & $\begin{array}{l}\text { Median } \\
\text { SR \& IQR }\end{array}$ & & $\begin{array}{l}\text { Median } \\
\text { SR \& IQR }\end{array}$ & & $\begin{array}{l}\text { Median } \\
\text { SR \& IQR }\end{array}$ & & $\begin{array}{l}\text { Median } \\
\text { SR \& IQR }\end{array}$ & \\
\hline $\begin{array}{l}\text { Beginner } \\
(5.6-5.8)\end{array}$ & 25 & $\begin{array}{c}10.0 \\
8.5\end{array}$ & A & $\begin{array}{l}2.0 \\
2.5\end{array}$ & A & $\begin{array}{l}3.0 \\
2.5\end{array}$ & A & $\begin{array}{l}5.0 \\
7.0\end{array}$ & A \\
\hline $\begin{array}{c}\text { Intermediate } \\
(5.9-5.10)\end{array}$ & 30 & $\begin{array}{l}10.5 \\
11.3\end{array}$ & A & $\begin{array}{l}2.0 \\
4.0\end{array}$ & A & $\begin{array}{l}2.0 \\
4.0\end{array}$ & A & $\begin{array}{l}6.0 \\
7.5\end{array}$ & A \\
\hline $\begin{array}{c}\text { Experienced } \\
(5.11-5.12)\end{array}$ & 28 & $\begin{array}{c}12.0 \\
8.5\end{array}$ & A & $\begin{array}{l}3.0 \\
3.8\end{array}$ & A & $\begin{array}{l}3.0 \\
2.8\end{array}$ & A & $\begin{array}{l}5.0 \\
6.8\end{array}$ & A \\
\hline $\begin{array}{c}\text { Expert } \\
(5.12+-5.14)\end{array}$ & 28 & $\begin{array}{l}4.5 \\
9.8\end{array}$ & B & $\begin{array}{c}1.0^{*} \\
2.0\end{array}$ & B & $\begin{array}{l}0.0 \\
3.0\end{array}$ & B & $\begin{array}{l}2.5 \\
7.0\end{array}$ & A \\
\hline
\end{tabular}

Appendix Table 2. 6: Cliff base SR (median values and IQR) across four taxonomic groups at all sites controlled by use intensity. Statistical significance is calculated using Kruskal-Wallis test. Columns that share a letter code are not significantly different from one at $\boldsymbol{\alpha}=\mathbf{0 . 0 5}$. 


\begin{tabular}{|c|c|c|c|c|c|c|c|c|c|c|}
\hline \multicolumn{2}{|c|}{ Grade Class } & $\mathbf{N}$ & \multicolumn{2}{|c|}{$\begin{array}{l}\text { TOTAL } \\
\text { Median } \\
\text { SR \& IQR }\end{array}$} & \multicolumn{2}{|c|}{$\begin{array}{l}\text { VASCULAR } \\
\text { Median } \\
\text { SR \& IQR }\end{array}$} & \multicolumn{2}{|c|}{$\begin{array}{l}\text { BRYOPHYTE } \\
\text { Median } \\
\text { SR \& IQR }\end{array}$} & \multicolumn{2}{|c|}{$\begin{array}{l}\text { LICHEN } \\
\text { Median } \\
\text { SR \& IQR }\end{array}$} \\
\hline 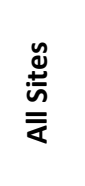 & $\begin{array}{l}\text { Climbed } \\
\text { Unclimbed }\end{array}$ & 32 & $\begin{array}{c}8.0 \\
9.0 \\
11.5 \\
12.3\end{array}$ & ns & $\begin{array}{l}2.0 \\
4.0 \\
2.0 \\
3.8\end{array}$ & ns & $\begin{array}{l}2.0 \\
2.0 \\
3.0 \\
5.0\end{array}$ & ns & $\begin{array}{l}4.0 \\
6.0 \\
6.0 \\
8.0\end{array}$ & ns \\
\hline 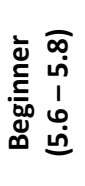 & $\begin{array}{l}\text { Climbed } \\
\text { Unclimbed }\end{array}$ & 17 & $\begin{array}{c}7.0 \\
8.0 \\
13.0 \\
7.3\end{array}$ & ns & $\begin{array}{l}2.0 \\
2.0 \\
2.0 \\
3.8\end{array}$ & 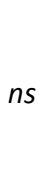 & $\begin{array}{l}2.0 \\
2.0 \\
\\
3.5 \\
3.5\end{array}$ & $P<0.05$ & $\begin{array}{l}3.0 \\
7.5 \\
\\
6.5 \\
6.3\end{array}$ & ns \\
\hline 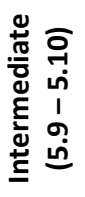 & Unclimbed & 22 & $\begin{array}{c}9.0 \\
11.3 \\
\\
14.5 \\
17.5\end{array}$ & ns & $\begin{array}{l}1.5 \\
4.0 \\
\\
2.5 \\
3.5\end{array}$ & ns & $\begin{array}{l}2.0 \\
2.3 \\
\\
4.5 \\
3.8\end{array}$ & ns & $\begin{array}{l}5.5 \\
7.3 \\
\\
9.0 \\
7.0\end{array}$ & ns \\
\hline 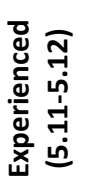 & Unclimbed & 20 & $\begin{array}{c}11.5 \\
8.5 \\
12.5 \\
10.8\end{array}$ & ns & $\begin{array}{l}3.0 \\
3.8 \\
4.0 \\
4.8\end{array}$ & ns & $\begin{array}{l}3.0 \\
3.0 \\
3.0 \\
3.3\end{array}$ & $n s$ & $\begin{array}{l}5.0 \\
4.8 \\
\\
6.5 \\
7.3\end{array}$ & ns \\
\hline 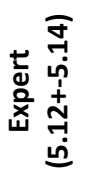 & Climbed & 20 & $\begin{array}{c}6.0 \\
10.3 \\
3.0 \\
6.5\end{array}$ & ns & $\begin{array}{l}1.0 \\
3.0 \\
\\
0.0 \\
1.8\end{array}$ & ns & $\begin{array}{l}0.0 \\
3.0 \\
0.0 \\
0.0\end{array}$ & $n s$ & $\begin{array}{l}2.5 \\
7.8 \\
\\
2.0 \\
5.0\end{array}$ & ns \\
\hline
\end{tabular}

Appendix Table 2. 7: Cliff base SR (median values and IQR) across four taxonomic groups controlled by difficulty. Statistical significance is calculated using Kruskal-Wallis test between groups within boxes. Groups that share the code "ns" are not significantly different from one another at $\alpha=0.05$. 


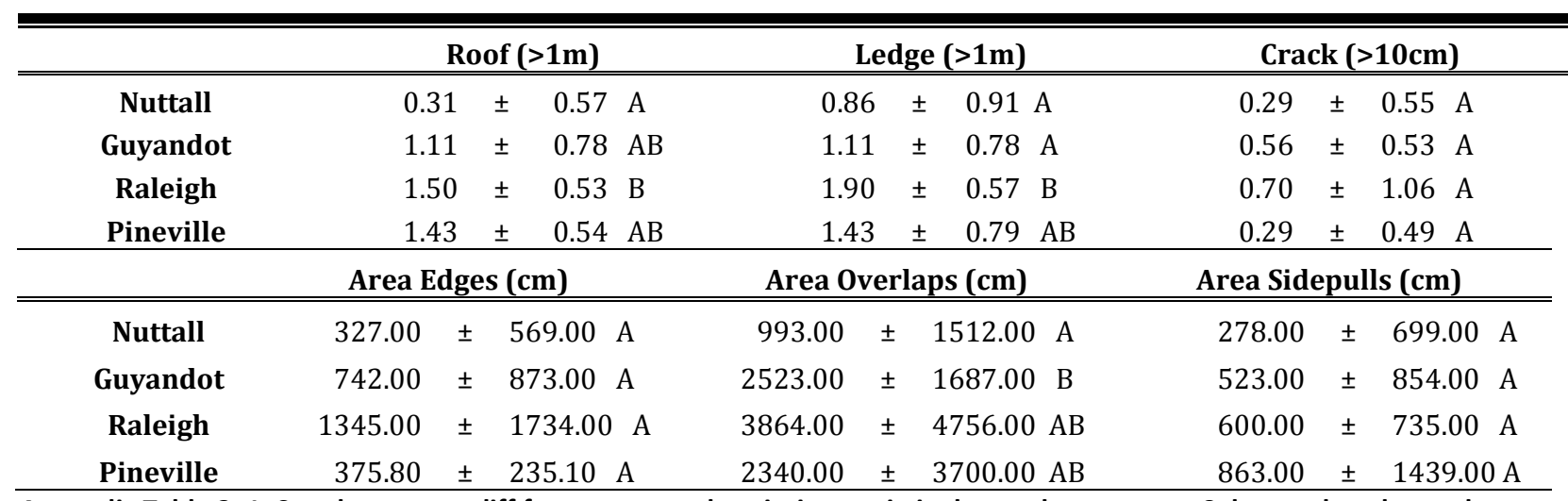

Appendix Table 3. 1: Supplementary cliff face structure descriptive statistics by sandstone type. Columns that share a letter code are not significantly different at $\alpha=0.05$ (T-test). 
Appendix Table 3. 2: Complete species list and cliff position where it was observed. Location codes are as follows: $F=$ Cliff Face (all sandstone types), $B=$ Cliff Base (Nuttall Sandstone only); $T=$ Cliff Top (Nuttall Sandstone only)

\begin{tabular}{|c|c|c|c|c|c|c|c|c|c|}
\hline Group & Family & Genus & Species & Author & $\begin{array}{c}\text { Subtaxon } \\
\text { type }\end{array}$ & Subtaxon & Subauthor & Common Name & Location \\
\hline Vascular & Aceraceae & Acer & pensylvanicum & L. & & & & striped maple & $\mathrm{F}$ \\
\hline Vascular & $\begin{array}{c}\text { Aceraceae } \\
\text { Poaceae }\end{array}$ & Acer & rubrum & L... & & & & red maple & $\mathrm{F}$ \\
\hline Vascular & $\begin{array}{c}\text { (Gramineae) } \\
\text { Poaceae }\end{array}$ & Agrostis & perennans & (Walt.) Tuckerman & & & & upland bentgrass & FBT \\
\hline Vascular & $\begin{array}{l}\text { (Gramineae) } \\
\text { Asteraceae }\end{array}$ & Agrostis & scabra & Willd & & & (L.) & rough bentgrass & $\mathrm{F}$ \\
\hline Vascular & (Compositae) & Ambrosia & artemisiifolia & L. & var & elatior & Descourtils & annual ragweed & $\mathrm{T}$ \\
\hline Vascular & $\begin{array}{c}\text { Rosaceae } \\
\text { Poaceae }\end{array}$ & Amelanchier & arborea & (Michx. f.) Fern. & var & arborea & & common serviceberry & $\mathrm{F}$ \\
\hline Vascular & (Gramineae) & Andropogon & gerardii & Vitman & & & & big bluestem & $\mathrm{F}$ \\
\hline Vascular & Aspleniaceae & Asplenium & montanum & Willd & & & & mountain spleenwort & FB \\
\hline Vascular & Aspleniaceae & Asplenium & pinnatifidum & Nutt & & & & lobed spleenwort & $\mathrm{F}$ \\
\hline Vascular & Aspleniaceae & Asplenium & platyneuron & (L.) Oaks & & & & ebony spleenwort & $\mathrm{F}$ \\
\hline Vascular & Dryopteridaceae & Athyrium & thelypterioides & (Michx.) Desv. & & & & $\begin{array}{l}\text { silvery athyrium } \\
\text { smooth yellow false }\end{array}$ & B \\
\hline Vascular & Scrophulariaceae & Aureolaria & flava & (L.) Farw. & var & flava & & foxglove & B \\
\hline Vascular & Scrophulariaceae & Aureolaria & $s p$. & Raf. & & & & false foxglove & $\mathrm{T}$ \\
\hline Vascular & Betulaceae & Betula & alleghaniensis & Britton & var. & alleghaniensis & & yellow birch & $\mathrm{F}$ \\
\hline Vascular & $\begin{array}{l}\text { Betulaceae } \\
\text { Asteraceae }\end{array}$ & Betula & lenta & L. & & & & sweet birch & $\mathrm{F}$ \\
\hline Vascular & (Compositae) & Bidens & vulgata & Greene & & & & big devils beggartick & FB \\
\hline Vascular & Poaceae & Brachyelytrum & erectum & (Schreb. ex Spreng.) Beauv. & & & & bearded shorthusk & B \\
\hline Vascular & Brassicaceae & Cardamine & angustata & O.E. Schulz & & & & slender toothwort & B \\
\hline Vascular & Cyperaceae & Carex & appalachica & J. Webber \& P.W. Ball & & & & appalachian aedge & B \\
\hline Vascular & Cyperaceae & Carex & debilis & Michx. & & & & $\begin{array}{l}\text { white edge sedge } \\
\text { broad looseflower }\end{array}$ & B \\
\hline Vascular & Cyperaceae & Carex & laxiflora & Lam & & & & sedge & FT \\
\hline Vascular & Cyperaceae & Carex & nigromarginata & Schwein. & & & & black edge sedge & $\mathrm{F}$ \\
\hline Vascular & Cyperaceae & Carex & pensylvanica & Lam. & & & & Pennsylvania sedge & $\mathrm{F}$ \\
\hline Vascular & Cyperaceae & Carex & platyphylla & Carey & & & & broadleaf sedge & $\mathrm{F}$ \\
\hline Vascular & Cyperaceae & Carex & $s p$ & L. & & & & sedge & FBT \\
\hline Vascular & Cyperaceae & Carex & swanii & (Fern.) Mackenzie & & & & swan's sedge & BT \\
\hline Vascular & Cyperaceae & Carex & tonsa & (Fernald) E.P. Bicknell & var. & rugosperma & (Mack.) Crins & parachute sedge & $\mathrm{F}$ \\
\hline Vascular & Cyperaceae & Carex & virescens & Muhl ex Willd & & & & ribbed sedge & BT \\
\hline Vascular & Cyperaceae & Carex & willdenowii & Schkuhr ex Willd & & & & willdenow's sedge & $\mathrm{T}$ \\
\hline Vascular & Juglandaceae & Carya & $s p$. & Nutt. & & & & hickory & $\mathrm{F}$ \\
\hline Vascular & Fabaceae & Cercis & canadensis & $\mathrm{L}$. & & & & eastern redbud & B \\
\hline
\end{tabular}




\begin{tabular}{|c|c|c|c|c|}
\hline Vascular & Chenopodiaceae & Chenopodium & simplex & (Torr.) Raf. \\
\hline Vascular & Onagraceae & Circaea & $s p$ & $\mathrm{~L}$ \\
\hline Vascular & Clethraceae & Clethra & acuminata & Michx. \\
\hline Vascular & $\begin{array}{l}\text { Orobanchaceae } \\
\text { Asteraceae }\end{array}$ & Conopholis & americana & (L.) Wallr. F. \\
\hline Vascular & $\begin{array}{l}\text { (Compositae) } \\
\text { Poaceae }\end{array}$ & Coreopsis & major & Walt. \\
\hline Vascular & $\begin{array}{l}\text { (Gramineae) } \\
\text { Poaceae }\end{array}$ & Danthonia & sericea & $\begin{array}{c}\text { Nutt. } \\
\text { (L.) Beauv. Ex. Roemer \& J.A. }\end{array}$ \\
\hline Vascular & (Gramineae) & Danthonia & spicata & Schultes \\
\hline Vascular & Dennstaedtiaceae & Dennstaedtia & punctilobula & (Michx.) T. Moore \\
\hline Vascular & $\begin{array}{c}\text { Poaceae } \\
\text { (Gramineae) } \\
\text { Poaceae }\end{array}$ & Dichanthelium & acuminatum & (Sw.) Gould \& C.A. Clark \\
\hline Vascular & $\begin{array}{l}\text { (Gramineae) } \\
\text { Poaceae }\end{array}$ & Dichanthelium & acuminatum & (Sw.) Gould \& C.A. Clark \\
\hline Vascular & $\begin{array}{l}\text { (Gramineae) } \\
\text { Poaceae }\end{array}$ & Dichanthelium & boscii & (Poir.) Gould \& C.A. Clark \\
\hline Vascular & (Gramineae) & Dichanthelium & commutatum & (Schult.) Gould \\
\hline Vascular & $\begin{array}{c}\text { Poaceae } \\
\text { (Gramineae) } \\
\text { Poaceae }\end{array}$ & Dichanthelium & commutatum & (J.A. Schultes) Gould \\
\hline Vascular & $\begin{array}{l}\text { (Gramineae) } \\
\text { Poaceae }\end{array}$ & Dichanthelium & dichotomum & (L.) Gould \\
\hline Vascular & $\begin{array}{l}\text { (Gramineae) } \\
\text { Poaceae }\end{array}$ & Dichanthelium & laxiflorum & (Lam.) Gould \\
\hline Vascular & (Gramineae) & Dichanthelium & linearifolium & (Scribn. Ex Nash) Gould \\
\hline Vascular & Dioscoreaceae & Dioscorea & quaternata & J.F. Gmel. \\
\hline Vascular & Dryopteridaceae & Dryopteris & carthusiana & (Vill.) H.P. Fuchs \\
\hline Vascular & Dryopteridaceae & Dryopteris & intermedia & (Muhl. ex Willd.) Gray \\
\hline Vascular & Dryopteridaceae & Dryopteris & marginalis & (L.) Gray \\
\hline Vascular & Poaceae & Elymus & hystrix & L. \\
\hline Vascular & $\begin{array}{l}\text { Ericaceae } \\
\text { Asteraceae }\end{array}$ & Epigaea & repens & L. \\
\hline Vascular & $\begin{array}{l}\text { (Compositae) } \\
\text { Asteraceae }\end{array}$ & Eupatorium & album & L. \\
\hline Vascular & $\begin{array}{l}\text { (Compositae) } \\
\text { Asteraceae }\end{array}$ & Eupatorium & sessilifolium & L. \\
\hline Vascular & (Compositae) & Eurybia & divaricata & (L.) Nesom \\
\hline Vascular & Fagaceae & Fagus & grandifolia & Ehrh. \\
\hline Vascular & Oleaceae & Fraxinus & americana & L. \\
\hline Vascular & Diapensiaceae & Galax & urceolata & (Poir.) Brummitt \\
\hline Vascular & Rubiaceae & Galium & aprine & L. \\
\hline
\end{tabular}

\begin{tabular}{|c|c|}
\hline $\begin{array}{l}\text { mapleleaf goosefoot } \\
\text { enchanter's } \\
\text { nightshade } \\
\text { mountain } \\
\text { sweetpepperbush }\end{array}$ & FT \\
\hline american cancer-root & BT \\
\hline greater tickseed & FBT \\
\hline downy danthonia & FBT \\
\hline $\begin{array}{l}\text { poverty oatgrass } \\
\text { eastern hayscented } \\
\text { fern }\end{array}$ & FBT \\
\hline tapered rosette grass & FBT \\
\hline western panicgrass & FBT \\
\hline bosc's panicgrass & $\mathrm{FB}$ \\
\hline variable panicgrass & $\mathrm{F}$ \\
\hline variable panicgrass & FBT \\
\hline $\begin{array}{l}\text { cypress panicgrass } \\
\text { openflower rosette } \\
\text { grass }\end{array}$ & FBT \\
\hline slimleaf panicgrass & FBT \\
\hline fourleaf yam & B \\
\hline $\begin{array}{l}\text { spinulose Woodfern } \\
\text { intermediate } \\
\text { woodfern }\end{array}$ & $\mathrm{FB}$ \\
\hline $\begin{array}{l}\text { marginal woodfern } \\
\text { eastern bottlebrush } \\
\text { grass }\end{array}$ & $\mathrm{F}$ \\
\hline trailing arbutus & FBT \\
\hline white thoroughwort & FT \\
\hline upland boneset & $\mathrm{T}$ \\
\hline white wood aster & FB \\
\hline american beech & $\mathrm{F}$ \\
\hline white ash & F \\
\hline beetleweed & FT \\
\hline stickywilly & $\mathrm{F}$ \\
\hline
\end{tabular}




\begin{tabular}{|c|c|c|c|c|c|c|}
\hline Vascular & Rubiaceae & Galium & triflorum & Michx. & & \\
\hline Vascular & Ericaceae & Gaultheria & procumbens & L. & & \\
\hline Vascular & Ericaceae & Gaylussacia & baccata & (Wangenh.) K. Koch & & \\
\hline Vascular & Rosaceae & Geum & virginianum & L. & & \\
\hline Vascular & Orchidaceae & Goodyera & repens & (L.) R. Br. & & \\
\hline Vascular & Hamamelidaceae & Hamamelis & virginiana & L.a & & \\
\hline Vascular & Saxifragaceae & Heuchera & americana & L. & & \\
\hline Vascular & $\begin{array}{l}\text { Saxifragaceae } \\
\text { Asteraceae }\end{array}$ & Heuchera & parviflora & Bartlett & & \\
\hline Vascular & (Compositae) & Hieracium & paniculatum & L. & & \\
\hline Vascular & Rubiaceae & Houstonia & longifolia & Gaertn. & & \\
\hline Vascular & Clusiaceae & Hypericum & mutilum & L. & & \\
\hline Vascular & Clusiaceae & Hypericum & mutilum & L. & & \\
\hline Vascular & Clusiaceae & Hypericum & mutilum & L. & & \\
\hline Vascular & Aquifoliaceae & Ilex & ораса & Aiton & var & ораса \\
\hline Vascular & Balsaminaceae & Impatiens & $s p$ & L. & & \\
\hline Vascular & Juncaceae & Juncus & secundus & P. Beauv. ex Poir. & & \\
\hline Vascular & Juncaceae & Juncus & tenuis & Willd. & & \\
\hline Vascular & Cupressaceae & Juniperus & virginiana & L. & var & virginiana \\
\hline Vascular & Ericaceae & Kalmia & latifolia & L. & & \\
\hline Vascular & $\begin{array}{l}\text { Urticaceae } \\
\text { Poaceae }\end{array}$ & Laportea & canadensis & (L.) Weddell & & \\
\hline Vascular & (Gramineae) & Leersia & virginica & Willd. & & \\
\hline Vascular & Magnoliaceae & Liriodendron & tulipifera & L. & & \\
\hline Vascular & Magnoliaceae & Magnolia & $s p$. & $\mathrm{L}$ & & \\
\hline Vascular & Liliaceae & Maianthemum & stellatum & (L.) Link & & \\
\hline Vascular & Perennial & Medeola & virginiana & L. & & \\
\hline Vascular & Rubiaceae & Mitchella & repens & $\mathrm{L}$. & & \\
\hline Vascular & Cornaceae & Nyssa & sylvatica & Marsh. & & \\
\hline Vascular & Betulaceae & Ostrya & virginiana & (Mill.) K. Koch & var & virginiana \\
\hline Vascular & Oxalidaceae & Oxalis & stricta & L. & & \\
\hline Vascular & Ericaceae & Oxydendrum & arboreum & (L.) DC. & & \\
\hline Vascular & Caryophyllaceae & Paronychia & canadensis & (L.) Wood & & \\
\hline Vascular & Vitaceae & Parthenocissus & quinquefolia & (L.) Planch. & & \\
\hline Vascular & Scrophulariaceae & Paulownia & tomentosa & (Thunb.) Sieb. \& Zucc. Ex Steud. & & \\
\hline Vascular & Lamiaceae & Perilla & frutescens & (L.) Britt. & & \\
\hline Vascular & Phytolaccaceae & Phytolacca & americana & L. & var. & americana \\
\hline Vascular & Pinaceae & Pinus & rigida & Mill. & & \\
\hline
\end{tabular}

\begin{tabular}{|c|c|}
\hline fragrant bedstraw & B \\
\hline wintergreen & BT \\
\hline black huckleberry & FT \\
\hline $\begin{array}{l}\text { cream avens } \\
\text { lesser rattlesnake } \\
\text { plantain }\end{array}$ & $\mathrm{F}$ \\
\hline america witchhazel & $\mathrm{F}$ \\
\hline american alumroot & FT \\
\hline littleflower alumroot & FB \\
\hline allegheny hawkweed & BT \\
\hline longleaf summer bluet & $\mathrm{T}$ \\
\hline $\begin{array}{l}\text { dwarf St. John's wort } \\
\text { common St. John's }\end{array}$ & $\mathrm{F}$ \\
\hline $\begin{array}{l}\text { wort } \\
\text { shrubby St. John's } \\
\text { wort }\end{array}$ & FT \\
\hline american holly & $\mathrm{F}$ \\
\hline jewelweed & B \\
\hline lopsided rush & FT \\
\hline poverty rush & FB \\
\hline eastern redcedar & $\mathrm{F}$ \\
\hline mountain laurel & FBT \\
\hline canadian woodnettle & FB \\
\hline whitegrass & FBT \\
\hline tuliptree & $\mathrm{F}$ \\
\hline $\begin{array}{l}\text { magnolia } \\
\text { starry false lily of the } \\
\text { valley }\end{array}$ & $\mathrm{F}$ \\
\hline indian cucumber & B \\
\hline partridgeberry & FBT \\
\hline blackgum & FBT \\
\hline hophornbeam & $\mathrm{F}$ \\
\hline common yellow oxalis & B \\
\hline $\begin{array}{l}\text { sourwood } \\
\text { smooth forked } \\
\text { nailwort }\end{array}$ & BT \\
\hline virginia creeper & FBT \\
\hline princess tree & $\mathrm{F}$ \\
\hline beefsteak plant & $\mathrm{F}$ \\
\hline american pokeweed & $\mathrm{FB}$ \\
\hline pitch pine & $\mathrm{F}$ \\
\hline
\end{tabular}




\begin{tabular}{|c|c|c|c|c|}
\hline Vascular & $\begin{array}{l}\text { Pinaceae } \\
\text { Poaceae }\end{array}$ & Pinus & virginiana & Mill. \\
\hline Vascular & (Gramineae) & Poa & cuspidata & Nutt. \\
\hline Vascular & Ruscaceae & Polygonatum & biflorum & (Walt.) Ell. \\
\hline Vascular & Ruscaceae & Polygonatum & pubescens & (Willd.) Pursh \\
\hline Vascular & Polygonaceae & Polygonum & convolvulus & L. \\
\hline Vascular & Polygonaceae & Polygonum & virginianum & L. \\
\hline Vascular & Polypodiaceae & Polypodium & virginianum & $\mathrm{L}$. \\
\hline Vascular & $\begin{array}{l}\text { Dryopteridaceae } \\
\text { Asteraceae }\end{array}$ & Polystichum & acrostichoides & (Michx.) Schott \\
\hline Vascular & (Compositae) & Prenanthes & $s p$. & L. \\
\hline Vascular & Rosaceae & Prunus & pensylvanica & L. f. \\
\hline Vascular & Dennstaedtiaceae & Pteridium & aquilinum & (L.) Kuhn \\
\hline Vascular & Fagaceae & Quercus & $a l b a$ & L. \\
\hline Vascular & Fagaceae & Quercus & coccinea & Münchh. \\
\hline Vascular & Fagaceae & Quercus & prinus & L. \\
\hline Vascular & Fagaceae & Quercus & rubra & $\mathrm{L}$. \\
\hline Vascular & Fagaceae & Quercus & velutina & Lam. \\
\hline Vascular & Ericaceae & Rhododendron & catawbiense & Michx. \\
\hline Vascular & Ericaceae & Rhododendron & maximum & L. \\
\hline Vascular & Anacardiaceae & Rhus & glabra & L. \\
\hline Vascular & Fabaceae & Robinia & pseudoacacia & L. \\
\hline Vascular & Rosaceae & Rosa & rugosa & Thunb. \\
\hline Vascular & Rosaceae & Rubus & $s p$. & L. \\
\hline Vascular & $\begin{array}{l}\text { Lauraceae } \\
\text { Poaceae }\end{array}$ & Sassafras & albidum & (Nutt.) Nees \\
\hline Vascular & (Gramineae) & Schizachyrium & scoparium & (Michx.) Nash \\
\hline Vascular & Crassulaceae & Sedum & ternatum & Michx. \\
\hline Vascular & Smilacaceae & Smilax & glauca & Walter \\
\hline Vascular & $\begin{array}{c}\text { Smilacaceae } \\
\text { Asteraceae }\end{array}$ & Smilax & rotundifolia & L. \\
\hline Vascular & $\begin{array}{c}\text { (Compositae) } \\
\text { Asteraceae }\end{array}$ & Solidago & curtisii & Torr. \& Gray \\
\hline Vascular & $\begin{array}{c}\text { (Compositae) } \\
\text { Asteraceae }\end{array}$ & Solidago & hispida & Muhl. Ex Willd. \\
\hline Vascular & $\begin{array}{c}\text { (Compositae) } \\
\text { Asteraceae }\end{array}$ & Solidago & $s p$ & L. \\
\hline Vascular & (Compositae) & Solidago & ulmifolia & Muhl. Ex Willd. \\
\hline Vascular & Anacardiaceae & Toxicodendron & radicans & (L.) Kuntze \\
\hline Vascular & Pinaceae & Tsuga & canadensis & L. Carrière \\
\hline Vascular & Ulmaceae & Ulmus & americana & $\mathrm{L}$. \\
\hline Vascular & Ericaceae & Vaccinium & pallidum & Aiton \\
\hline
\end{tabular}

\begin{tabular}{|c|c|}
\hline virginia pine & $\mathrm{F}$ \\
\hline early bluegrass & $\mathrm{F}$ \\
\hline smooth Solomon's seal & $\mathrm{T}$ \\
\hline hairy Solomon's seal & FB \\
\hline black bindweed & $\mathrm{T}$ \\
\hline jumpseed & B \\
\hline rock polypody & FBT \\
\hline christmas fern & FB \\
\hline rattlesnakeroot & B \\
\hline pin cherry & B \\
\hline western brackenfern & B \\
\hline white oak & $\mathrm{F}$ \\
\hline scarlet oak & $\mathrm{F}$ \\
\hline chestnut oak & $\mathrm{F}$ \\
\hline northen red oak & $\mathrm{F}$ \\
\hline black oak & $\mathrm{F}$ \\
\hline Catawba rosebay & FBT \\
\hline great laurel & FBT \\
\hline Smooth sumac & $\mathrm{F}$ \\
\hline black locust & $\mathrm{F}$ \\
\hline rugosa rose & $\mathrm{T}$ \\
\hline blackberry & FBT \\
\hline sassafras & $\mathrm{F}$ \\
\hline little bluestem & FBT \\
\hline woodland stonecrop & $\mathrm{F}$ \\
\hline cat greenbrier & FBT \\
\hline $\begin{array}{l}\text { roundleaf greenbrier } \\
\text { mountain decumbent } \\
\text { goldenrod }\end{array}$ & FBT \\
\hline hairy goldenrod & $\mathrm{T}$ \\
\hline goldenrod & FBT \\
\hline elmleaf goldenrod & B \\
\hline eastern poison ivy & FBT \\
\hline eastern hemlock & $\mathrm{F}$ \\
\hline american elm & $\mathrm{F}$ \\
\hline blue ridge blueberry & FBT \\
\hline
\end{tabular}




\begin{tabular}{|c|c|c|c|c|c|c|}
\hline Vascular & Ericaceae & Vaccinium & stamineum & $\mathrm{L}$. & & \\
\hline Vascular & Verbenaceae & Verbena & stricta & Vent. & & \\
\hline Vascular & Adoxaceae & Viburnum & stamineum & L. & & \\
\hline Vascular & Violaceae & Viola & xprimulifolia & $\mathrm{L}$. & & \\
\hline Vascular & Violaceae & Viola & blanda & Willd. & var. & blanda \\
\hline Vascular & Violaceae & Viola & hastata & Michx. & & \\
\hline Vascular & Violaceae & Viola & sororia & Willd. & & \\
\hline Vascular & Vitaceae & Vitis & aestivalis & Michx. & var. & bicolor Deam \\
\hline Lichen & Acarosporaceae & Acarospora & fuscata & (Schrader) Th.Fr. & & \\
\hline Lichen & Parmeliaceae & Allocetraria & oakesiana & (Tuck.) Randlane \& A. Thell & & \\
\hline Lichen & Physciaceae & Amandinea & punctata & (Hoffm.) Coppins \& Scheid. & & \\
\hline Lichen & Monoblastiaceae & Anisomeridium & distans & (Willey) R.C. Harris & & \\
\hline Lichen & Megasporaceae & Aspicilia & caesiocinerea & (Nyl. ex Malbr.) Arnold & & \\
\hline Lichen & Megasporaceae & Aspicilia & cinerea & (L.) Körber & & \\
\hline Lichen & Megasporaceae & Aspicilia & laevata & (Ach.) Arnold & & \\
\hline Lichen & Physciaceae & Buellia & badia & (Fr.) A. Massal. & & \\
\hline Lichen & Physciaceae & Buellia & maculata & Bungartz & & \\
\hline Lichen & Physciaceae & Buellia & spuria & (Schaerer) Anzi & & \\
\hline Lichen & Physciaceae & Buellia & vermicoma & (Tuck.) Tuck. & & \\
\hline Lichen & Teloschistaceae & Caloplaca & flavovirescens & (Wulfen) Dalla Torre \& Sarnth. & & \\
\hline Lichen & Teloschistaceae & Caloplaca & reptans & Auct. Lendemer & & \\
\hline Lichen & Parmeliaceae & Canomaculina & subtinctoria & (Zahlbr.) Elix & & \\
\hline Lichen & Parmeliaceae & Canoparmelia & amabilis & Heiman \& Elix & & \\
\hline Lichen & Parmeliaceae & Canoparmelia & texana & (Tuck.) Elix \& Hale & & \\
\hline Lichen & Catillariaceae & Catillaria & chalybeia & (Borrer) A.Massal. & & \\
\hline Lichen & Chrysothricaceae & Chrysothrix & insulizans & R.C. Harris \& Ladd & & \\
\hline Lichen & Chrysothricaceae & Chrysothrix & susquehannensis & Lendemer \& Elix & & \\
\hline Lichen & Chrysothricaceae & Chrysothrix & xanthina & (Vain.) Kalb. & & \\
\hline Lichen & Cladoniaceae & Cladonia & apodocarpa & Robbins & & \\
\hline Lichen & Cladoniaceae & Cladonia & arbuscula & (Wallr.) Flotow & & \\
\hline Lichen & Cladoniaceae & Cladonia & atlantica & A.Evans & & \\
\hline Lichen & Cladoniaceae & Cladonia & beaumontii & (Tuck.) Fink & & \\
\hline Lichen & Cladoniaceae & Cladonia & caroliniana & (Schwein.) Tuck. & & \\
\hline Lichen & Cladoniaceae & Cladonia & chlorophaea & (Flörke ex Sommerf.) Sprengel & & \\
\hline Lichen & Cladoniaceae & Cladonia & coniocraea/ochrochlora & & & \\
\hline Lichen & Cladoniaceae & Cladonia & cristatella & Tuck. & & \\
\hline Lichen & Cladoniaceae & Cladonia & didyma & (Fée) Vainio & & \\
\hline
\end{tabular}

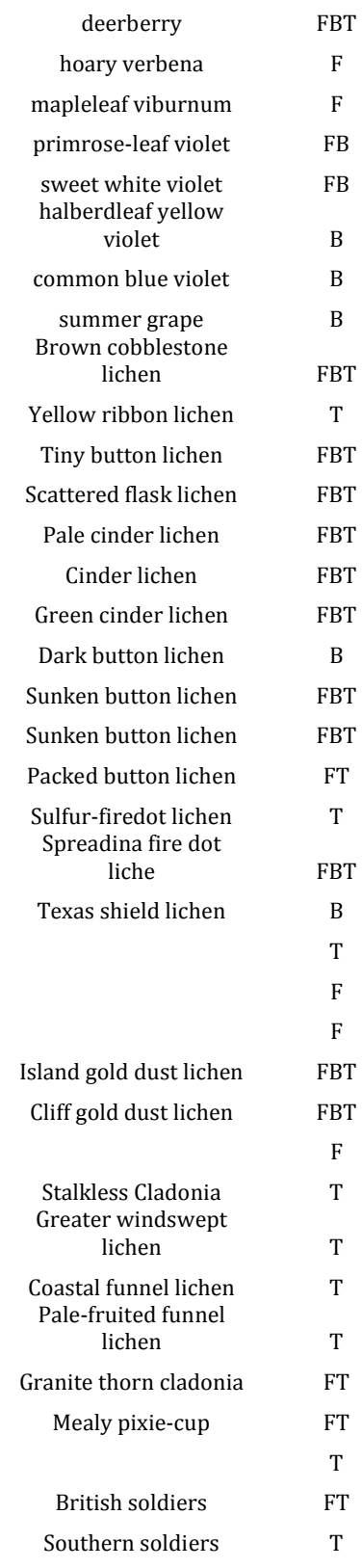




\begin{tabular}{|c|c|c|c|c|c|c|c|c|}
\hline Lichen & Cladoniaceae & Cladonia & fimbriata & (L.) Fr. & & & & Trumpet lichen \\
\hline Lichen & Cladoniaceae & Cladonia & furcata & (Hudson) Schrad. & & & & Many-forked cladonia \\
\hline Lichen & Cladoniaceae & Cladonia & macilenta & Hoffm. & & & & Lipstick powderhorn \\
\hline Lichen & Cladoniaceae & Cladonia & parasitica & (Hoffm.) Hoffm. & & & & Fence-rail cladonia \\
\hline Lichen & Cladoniaceae & Cladonia & petrophila & R.C.Harris. & & & & Rock leaf lichen \\
\hline Lichen & Cladoniaceae & Cladonia & pleurota & (Flörke) Schaerer & & & & Red-fruited Pixie-cup \\
\hline Lichen & Cladoniaceae & Cladonia & pyxidata & (L.) Hoffm. & & & & Pebbled Pixie-cup \\
\hline Lichen & Cladoniaceae & Cladonia & sobolescens & Nyl. ex Vainio & & & & \\
\hline Lichen & Cladoniaceae & Cladonia & $s p$. & P.Browne & & & & \\
\hline Lichen & Cladoniaceae & Cladonia & squamosa & (Scop.) Hoffm. & & & & Dragon cladonia \\
\hline Lichen & Cladoniaceae & Cladonia & strepsilis & (Ach.) Grognot & & & & Olive cladonia \\
\hline Lichen & Cladoniaceae & Cladonia & subcariosa & Nyl. & & & & Peg lichen \\
\hline Lichen & Cladoniaceae & Cladonia & subtenuis & (Abbayes) Mattick & & & & \\
\hline Lichen & Cladoniaceae & Cladonia & turgida & Ehrh. ex Hoffm. & & & & Crazy-scale lichen \\
\hline Lichen & Cladoniaceae & Cladonia & uncialis & (L.) Weber ex F.H.Wigg. & & & & Thorn cladonia \\
\hline Lichen & Collemataceae & Collema & furfuraceum & (Arnold) Du Rietz & & & & \\
\hline Lichen & Family not assigned & Cystocoleus & ebeneus & (Dillwyn) Thwaites & & & & Rock gossamer \\
\hline Lichen & Verrucariaceae & Dermatocarpon & luridum & (With.) J.R. Laundon & var & luridum & & \\
\hline Lichen & Verrucariaceae & Dermatocarpon & muhlenbergii & (Ach.) Müll. Arg. & & & & \\
\hline Lichen & Icmadophilaceae & Dibaeis & baeomyces & (L. f.) Rambold \& Hertel & & & & $\begin{array}{l}\text { Pink Earth Lichen } \\
\text { Golden moonglow }\end{array}$ \\
\hline Lichen & Physciaceae & Dimelaena & oreina & (Ach.) Norman & & & & lichen \\
\hline Lichen & Thelotremataceae & Diploschistes & actinostomus & (Ach.) Zalhbr. & & & & Eastern crater lichen \\
\hline Lichen & Thelotremataceae & Diploschistes & muscorum & R. Sant. & & & & Cowpie lichen \\
\hline Lichen & Thelotremataceae & Diploschistes & scuposus & (Schreb.) Norman & & & & \\
\hline Lichen & Physciaceae & Dirinaria & frostii & (Tuck.) Hale \& Culb & & & & \\
\hline Lichen & Roccellaceae & Enterographa & hutchinsiae & (Leight.) A. Massal. & & & & $\begin{array}{c}\text { Rock Script } \\
\text { Rock greenshield }\end{array}$ \\
\hline Lichen & Parmeliaceae & Flavoparmelia & baltimorensis & (Gyeln. \& Fóriss) Hale & & & & $\begin{array}{c}\text { lichen } \\
\text { Common greenshield }\end{array}$ \\
\hline Lichen & Parmeliaceae & Flavoparmelia & caperata & (L.) Hale & & & & lichen \\
\hline Lichen & Fuscideaceae & Fuscidea & recensa & (Stirton) Hertel, V. Wirth \& Vezda & & & & \\
\hline Lichen & Fuscideaceae & Fuscidea & recensa & (Stirton) Hertel, V. Wirth \& Vĕzda & var. & arcuatula & Fryday & Quilt lichen \\
\hline Lichen & Lecideaceae & Hуросепотусе & scalaris & (Ach. ex Lilj.) M. Choisy & & & & Common clam lichen \\
\hline Lichen & Parmeliaceae & Hypogymnia & physodes & (L.) Nyl. & & & & Monk's hood lichen \\
\hline Lichen & Parmeliaceae & Imshaugia & aleurites & (Ach.) S.L.F. Mey. & & & & Salted starburst lichen \\
\hline Lichen & Umbilicariaceae & Lasallia & papulosa & (Ach.) Llano & & & & Common toadskin \\
\hline Lichen & Umbilicariaceae & Lasallia & pennsylvanica & (Hoffm.) Llano & & & & \\
\hline Lichen & Lecanoraceae & Lecanora & thysanophora & R.C.Harris & & & & Mapledust lichen \\
\hline Lichen & Lecideaceae & Lecidea & cyrtidia & Tuck. & & & & \\
\hline
\end{tabular}




\begin{tabular}{|c|c|c|c|c|}
\hline Lichen & Stereocaulaceae & Lepraria & caesiella & R.C.Harris \\
\hline Lichen & Stereocaulaceae & Lepraria & caesioalba & (de Lesd.) J.R.Laundon \\
\hline Lichen & Stereocaulaceae & Lepraria & cryophila & Lendemer \\
\hline Lichen & Stereocaulaceae & Lepraria & eburnea & J. R. Laundon \\
\hline Lichen & Stereocaulaceae & Lepraria & elobata & Tønsberg \\
\hline Lichen & Stereocaulaceae & Lepraria & lobificans & Nyl. \\
\hline Lichen & Stereocaulaceae & Lepraria & neglecta & (Nyl.) Lettau \\
\hline Lichen & Stereocaulaceae & Lepraria & normandinioides & Lendemer \& R.C.Harris \\
\hline Lichen & Collemataceae & Leptogium & minutissimum & (Flörke) Fr. \\
\hline Lichen & Lichenotheliaceae & Lichenothelia & $s p$. & D. Hawksw. \\
\hline Lichen & Loxosporaceae & Loxospora & pustulata & (Brodo \& W.L. Culb.) R.C. Harri \\
\hline Lichen & Parmeliaceae & Melanelia & culbersonii & (Hale) A. Thell \\
\hline Lichen & Parmeliaceae & Myelochroa & aurulenta & (Tuck.) Elix \& Hale \\
\hline Lichen & Parmeliaceae & Myelochroa & obsessa & (Ach.) Elix \& Hale \\
\hline Lichen & Incertae sedis & Normandia & pulchella & (Borrer) Nyl. \\
\hline Lichen & Parmeliaceae & Parmelia & sulcata & Taylor \\
\hline Lichen & Parmeliaceae & Parmeliopsis & horrescens & (Taylor) Elix \& Hale \\
\hline Lichen & Parmeliaceae & Parmeliopsis & minarum & (Vain.) Elix \& Hale \\
\hline Lichen & Physciaceae & Phaeophyscia & rubropulchra & (Degel.) Essl. \\
\hline Lichen & Phlyctidaceae & Phlyctis & petraea & R.C. Harris ined. \\
\hline Lichen & Physciaceae & Physcia & millegrana & Degel. \\
\hline Lichen & Physciaceae & Physcia & subtilis & Degel. \\
\hline Lichen & Agyriaceae & Placynthiella & icmalea & (Ach.) Coppins \& P.James \\
\hline Lichen & Acarosporaceae & Polysporina & simplex & Vĕzda \\
\hline Lichen & Porpidiaceae & Porpidia & albocaerulescens & (Wulfen) Hertel \& Knoph \\
\hline Lichen & Porpidiaceae & Porpidia & crustulata & (Ach.) Hertel \& Knoph \\
\hline Lichen & Porpidiaceae & Porpidia & macrocarpa & (DC.) Hertel \& A. J. Schwab \\
\hline Lichen & Lecideaceae & Porpidia & $s p$ & Körb. \\
\hline Lichen & Porpidiaceae & Porpidia & subsimplex & (H. Magn.) Fryday \\
\hline Lichen & Micareaceae & Psilolechia & lucida & (Ach.) M.Choisy \\
\hline Lichen & Parmeliaceae & Punctelia & missouriensis & G.Wilh. \& Ladd \\
\hline Lichen & Parmeliaceae & Punctelia & redecta & (Ach.) Krog \\
\hline Lichen & Parmeliaceae & Punctelia & subrudecta & (Nyl.) Krog \\
\hline Lichen & Cladoniaceae & Pycnothelia & papillaria & (Ehrh.) Dufour \\
\hline
\end{tabular}

\begin{tabular}{|c|c|}
\hline Gray dust lichen & FBT \\
\hline Grainy dust lichen & FBT \\
\hline \multirow[t]{2}{*}{ Cold dust lichen } & $\mathrm{FB}$ \\
\hline & $\mathrm{F}$ \\
\hline Smooth dust lichen & $\mathrm{F}$ \\
\hline Fluffy dust lichen & FBT \\
\hline \multirow[t]{3}{*}{ Zoned dust lichen } & FBT \\
\hline & FBT \\
\hline & $\mathrm{F}$ \\
\hline Black rock lichen & FB \\
\hline \multirow{4}{*}{$\begin{array}{l}\text { Pustule crust lichen } \\
\text { Appalachian } \\
\text { camouflage lichen } \\
\text { Powdery axil-bristle } \\
\text { lichen }\end{array}$} & B \\
\hline & FT \\
\hline & \\
\hline & FBT \\
\hline Rock axil-bristle lichen & FBT \\
\hline \multirow{6}{*}{$\begin{array}{l}\text { Hammered shield } \\
\text { lichen } \\
\text { Hairy-spined shield } \\
\text { lichen } \\
\text { Hairless-spined shield } \\
\text { lichen }\end{array}$} & \\
\hline & $\mathrm{T}$ \\
\hline & FT \\
\hline & \\
\hline & FBT \\
\hline & B \\
\hline Rock wash & FBT \\
\hline Mealy rosette lichen & FBT \\
\hline \multirow[t]{2}{*}{ Slender rossette lichen } & FBT \\
\hline & $\mathrm{T}$ \\
\hline \multirow{5}{*}{$\begin{array}{l}\text { Common coal-dust } \\
\text { lichen } \\
\text { Smoky-eye boulder } \\
\text { lichen } \\
\begin{array}{c}\text { Concentric boulder } \\
\text { lichen }\end{array}\end{array}$} & FT \\
\hline & \\
\hline & FBT \\
\hline & FBT \\
\hline & $\mathrm{T}$ \\
\hline \multirow{2}{*}{\multicolumn{2}{|c|}{$\begin{array}{l}\text { Scalloped boulder } \\
\text { lichen }\end{array}$}} \\
\hline & $\mathrm{FB}$ \\
\hline \multirow{4}{*}{$\begin{array}{l}\text { Sulfur-dust lichen } \\
\text { Prairie speckled shield } \\
\text { lichen } \\
\text { Rough speckled shield } \\
\text { lichen }\end{array}$} & FB \\
\hline & FRT \\
\hline & \\
\hline & FBT \\
\hline Forest speckleback & FBT \\
\hline Nipple Lichen & BT \\
\hline
\end{tabular}




\begin{tabular}{|c|c|c|c|c|}
\hline Lichen & Ramalinaceae & Ramalina & intermedia & (Delise ex Nyl.) Nyl \\
\hline Lichen & Ramalinaceae & Ramalina & petrina & Bowler \& Rundel \\
\hline Lichen & Ramalinaceae & Ramalina & pollinaria & (Westr.) Ach. \\
\hline Lichen & Rhizocarpaceae & Rhizocarpon & grande & (Flörke ex Flotow) Arnold \\
\hline Lichen & Rhizocarpaceae & Rhizocarpon & reductum & Th.Fr. \\
\hline Lichen & Lecanoraceae & Rhizoplaca & subdiscrepans & (Nyl.) R. Sant. \\
\hline Lichen & Physciaceae & Rinodina & sioxiana & J.W. Sheard \\
\hline Lichen & Acarosporaceae & Sarcogyne & clavus & (DC.) Krempelh. \\
\hline Lichen & Acarosporaceae & Sarcogyne & similis & H. Magn. \\
\hline Lichen & Scoliciosporaceae & Scoliciosporum & chlorococcum & (Stenh.) Vezda \\
\hline Lichen & Lecanoraceae & Scoliciosporum & umbrinum & (Ach.) Arnold \\
\hline Lichen & Trichotheliaceae & Segestria & leptalea & (Durieu \& Mont.) R.C. Harris \\
\hline Lichen & Agyriaceae & Trapelia & coarctata & (Sm.) M. Choisy \\
\hline Lichen & Agyriaceae & Trapelia & glebulosa & (Sm.) J. R. Laundon \\
\hline Lichen & Trapeliaceae & Trapelia & placodioides & Coppins \& P. James \\
\hline Lichen & Trapeliaceae & Trapeliopsis & granulosa & (Hoffm.) Lumbsch \\
\hline Lichen & Trapeliaceae & Trapelia & viridescens & (Schrader) Coppins \& P.James \\
\hline Lichen & Parmeliaceae & Tuckermannopsis & ciliaris & (Ach.) Gyelnik \\
\hline Lichen & Umbilicariaceae & Umbilicaria & americana & Poelt \& T.H. Nash \\
\hline Lichen & Umbilicariaceae & Umbilicaria & mammulata & (Ach.) Tuck. \\
\hline Lichen & Umbilicariaceae & Umbilicaria & muehlenbergii & (Ach.) Tuck. \\
\hline Lichen & Parmeliaceae & Usnea & subscabrosa & Nyl. ex Motyka \\
\hline Lichen & Parmeliaceae & Usnea & trichodea & Ach. \\
\hline Lichen & Parmeliaceae & Xanthoparmelia & angustiphylla & (Gyeln.) Hale \\
\hline Lichen & Parmeliaceae & Xanthoparmelia & australasica & D.J.Galloway \\
\hline Lichen & Parmeliaceae & Xanthoparmelia & conspersa & (Ach.) Hale \\
\hline Lichen & Parmeliaceae & Xanthoparmelia & cumberlandia & (Gyel.) Hale \\
\hline Lichen & Parmeliaceae & Xanthoparmelia & plittii & (Gyelnik) Hale \\
\hline Lichen & Parmeliaceae & Xanthoparmelia & tasmanica & (Hook.f. \& Taylor) Hale \\
\hline Lichen & Parmeliaceae & Xanthoparmelia & viriduloumbrina & (Gyeln.) Lendemer \\
\hline Bryophyte & Andreaeaceae & Andreaea & rothii & F.Weber \& D. Mohr \\
\hline Bryophyte & Anomodontaceae & Anomodon & attenuatus & (Hedw.) Hüb. \\
\hline Bryophyte & Anomodontaceae & Anomodon & rostratus & (Hedw.) Schimp. \\
\hline Bryophyte & Polytrichaceae & Atrichum & angustatum & (Brid.) Bruch \& Schimp. \\
\hline Bryophyte & Polytrichaceae & Atrichum & crispum & (James) Sull. \\
\hline Bryophyte & Polytrichaceae & Atrichum & tenellum & (Röhl.) Bruch \& Schimp. \\
\hline Bryophyte & Aulacomniaceae & Aulacomnium & palustre & (Hedw.) Schwägr. \\
\hline
\end{tabular}

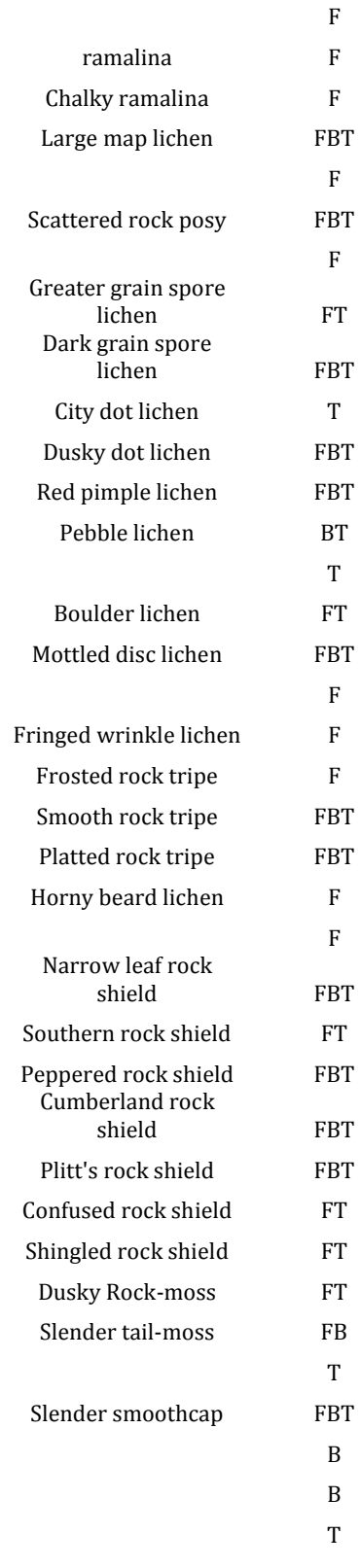




\begin{tabular}{|c|c|c|c|c|}
\hline Bryophyte & Lepidoziaceae & Bazzania & tricrenata & (Wahlenb.) Lindb. \\
\hline Bryophyte & Lepidoziaceae & Bazzania & trilobata & (L.) A. Gray \\
\hline Bryophyte & Brachytheciaceae & Brachythecium & oedipodium & (Mitt.) A. Jaeger \\
\hline Bryophyte & Dicranaceae & Brothera & leana & (Sull.) Müll. Hal. \\
\hline Bryophyte & Sematophyllaceae & Brotherella & recurvans & (Michx.) Fleisch. \\
\hline Bryophyte & Brachytheciaceae & Bryoandersonia & illecebra & (Hedw.) H. Rob. \\
\hline Bryophyte & Bryaceae & Bryum & argenteum & Hedw. \\
\hline Bryophyte & Bryaceae & Bryum & capillare & $\begin{array}{l}\text { Hedw. } \\
\text { (F. Weber \& D. Mohr) Bednarek- }\end{array}$ \\
\hline Bryophyte & Grimmiaceae & Bucklandiella & affinis & $\begin{array}{l}\text { Ochyra \& Ochyra in R. Ochyra } \\
\text { (Hedwig) Bednarek-Ochyra \& }\end{array}$ \\
\hline Bryophyte & Grimmiaceae & Bucklandiella & heterosticha & Ochyra in R. Ochyra et al., Cens. \\
\hline Bryophyte & Hypnaceae & Callicladium & haldanianum & (Grev.) H.A. Crum \\
\hline Bryophyte & Calypogeiaceae & Calypogeia & fissa & (L.) Raddi \\
\hline Bryophyte & Calypogeiaceae & Calypogeia & muelleriana & (Schiffn.) Müll. Frib. \\
\hline Bryophyte & Calypogeiaceae & Calypogeia & sullivantii & Austin \\
\hline Bryophyte & Amblystegiaceae & Campylium & chrysophyllum & (Brid.) J. Lange \\
\hline Bryophyte & Dicranaceae & Campylopus & tallulensis & Sull. \& Lesq. \\
\hline Bryophyte & Cephaloziellaceae & Cephaloziella & byssacea & (Roth) Warnst. \\
\hline Bryophyte & Cephaloziellaceae & Cephaloziella & spinicaulis & Douin \\
\hline Bryophyte & Grimmiaceae & Codriophorus & aciculare & (Hedwig) P. Beauvois \\
\hline Bryophyte & Lejeuneaceae & Coleolejeunea & biddlecomiae & (Austin) A.Evans \\
\hline Bryophyte & Dicranaceae & Dicranella & heteromalla & (Hedwig) Schimper \\
\hline Bryophyte & Dicranaceae & Dicranum & condensatum & Hedw. \\
\hline Bryophyte & Dicranaceae & Dicranum & flagellare & Hedw. \\
\hline Bryophyte & Dicranaceae & Dicranum & fulvum & Hook. \\
\hline Bryophyte & Dicranaceae & Dicranum & montanum & Hedw. \\
\hline Bryophyte & Dicranaceae & Dicranum & scoparium & Hedw. \\
\hline Bryophyte & Dicranaceae & Dicranum & spurium & Hedw. \\
\hline Bryophyte & Diphysciaceae & Diphyscium & foliosum & (Hedw.) D.Mohr \\
\hline Bryophyte & Scapaniaceae & Diplophyllum & apiculatum & (A. Evans) Steph. \\
\hline Bryophyte & Entodontaceae & Entodon & brevisetus & (Hook. \& Wilson) Lindb. \\
\hline Bryophyte & Fissidentaceae & Fissidens & taxifolis & Hedw. \\
\hline Bryophyte & Jubulaceae & Frullania & asagrayana & Montagne \\
\hline Bryophyte & Jubulaceae & Frullania & eboracensis & Gottsche \\
\hline Bryophyte & Grimmiaceae & Grimmia & laevigata & (Brid.) Brid. \\
\hline Bryophyte & Grimmiaceae & Grimmia & pilifera & P. Beauv. \\
\hline Bryophyte & Hedwigiaceae & Hedwigia & ciliata & (Hedw.) P. Beauv. \\
\hline
\end{tabular}

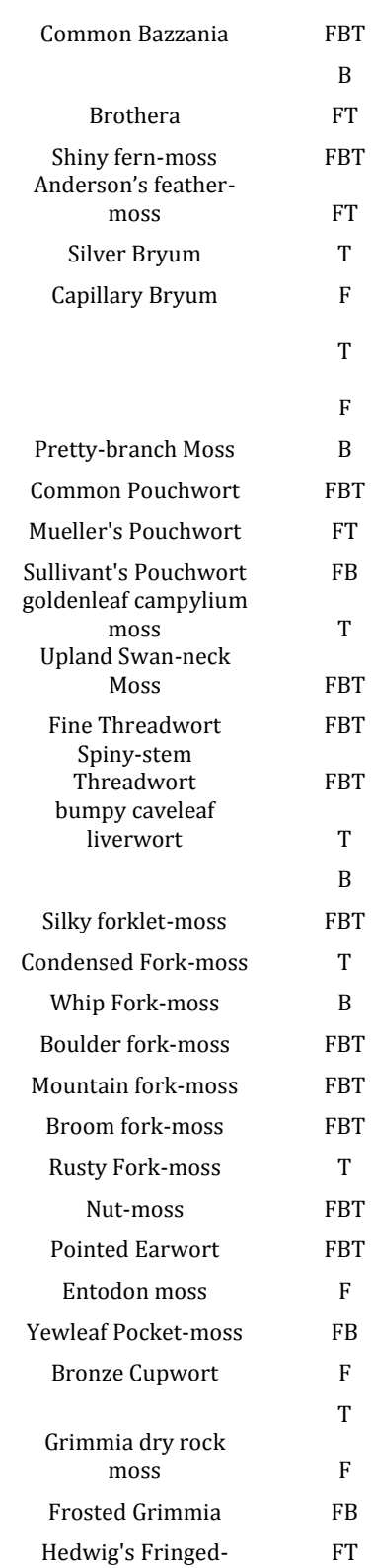


moss

\begin{tabular}{|c|c|c|c|c|c|c|}
\hline Bryophyte & Hypnaceae & Homomallium & adnatum & (Schimp.) Loeske & $\begin{array}{l}\text { Arrow Feather-moss } \\
\text { Hygroamblystegium }\end{array}$ & FBT \\
\hline Bryophyte & Amblystegiaceae & Hygroamblystegium & tenax & (Hedw.) Jenn. & moss & $\mathrm{F}$ \\
\hline Bryophyte & Hypnaceae & Нурпит & fertile & Sendtn. & Fertile Plait-moss & B \\
\hline Bryophyte & Hypnaceae & Нурпит & imponens & Hedw. & Flat Plait-moss & FBT \\
\hline Bryophyte & Jungermanniaceae & Jamesoniella & autumnalis & (De Candolle) Stephani & & $\mathrm{F}$ \\
\hline Bryophyte & Jubulaceae & Jubula & pennsylvanic & (Steph.) Evans & & B \\
\hline Bryophyte & Lepidoziaceae & Kurzia & sylvatica & (A. Evans) Grolle & Woods Fingerwort & BT \\
\hline Bryophyte & Lejeuneaceae & Lejeunea & ruthii & (A. Evans) R.M. Schust. & Ruth's Pouncewort & $\mathrm{F}$ \\
\hline Bryophyte & Lejeuneaceae & Lejeunea & ulicina & (Taylor) Gottsche & Ruth's Pouncewort & FB \\
\hline Bryophyte & Leucobryaceae & Leucobryum & albidum & Lindberg & Small white-moss & FT \\
\hline Bryophyte & Leucobryaceae & Leucobryum & glaucum & (Hedw.) Ångstr. & $\begin{array}{l}\text { Large white-moss } \\
\text { Common White }\end{array}$ & FBT \\
\hline Bryophyte & Lejeuneaceae & Leucolejeunea & clypeata & (Schwein.) A. Evans & Pouncewort & FB \\
\hline Bryophyte & Geocalycaceae & Lophocolea & heterophylla & (Schrad.) Dumort. & & B \\
\hline Bryophyte & Jungermanniaceae & Lophozia & bicrenata & (Schmidel ex Hoffm.) Dumort. & & $\mathrm{T}$ \\
\hline Bryophyte & Cephaloziaceae & Odontoschisma & prostratum & (Sw.) Trevis. & Prostrate Flapwort & FT \\
\hline Bryophyte & Pallaviciniaceae & Pallavicinia & lyellii & (Hook.) Carruth. & Ribbonwort & B \\
\hline Bryophyte & Pelliaceae & Pellia & epiphylla & (L.) Corda & Overleaf Pellia & $\mathrm{F}$ \\
\hline Bryophyte & Bartramiaceae & Philonotis & fontana & (Hedw.) Brid. & Fountain Applemoss & B \\
\hline Bryophyte & Plagiotheciaceae & Plagiothecium & denticulatum & (Hedw.) Schimp. & Dented Silk-moss & BT \\
\hline Bryophyte & Plagiotheciaceae & Plagiothecium & laetum & Schimp. in B.S.G. & Pleasing Silk-moss & B \\
\hline Bryophyte & Hypnaceae & Platygyrium & repens & (Brid.) Schimp. in B.S.G. & Flat Brocade-Moss & FBT \\
\hline Bryophyte & Amblystegiaceae & Playtolomella & lescurii & (Sull. in Gray) A.L. Andrews & Bordered Brook-moss & B \\
\hline Bryophyte & Polytrichaceae & Pogonatum & pensilvanicum & (Hedwig) P. Beauvois, & & $\mathrm{T}$ \\
\hline Bryophyte & Mniaceae & Pohlia & nutans & (Hedw.) Lindb. & Noddling Thread-moss & FBT \\
\hline Bryophyte & Mniaceae & Pohlia & $s p$ & (Hedw.) & & $\mathrm{T}$ \\
\hline Bryophyte & Polytrichaceae & Polytrichum & commune & Hedw. & Common Haircap & FBT \\
\hline Bryophyte & Polytrichaceae & Polytrichum & juniperinum & Hedw. & Juniper Haircap & $\mathrm{T}$ \\
\hline Bryophyte & Polytrichaceae & Polytrichum & ohioense & Ren. \& Card. & Ohio haircap & FBT \\
\hline Bryophyte & Polytrichaceae & Polytrichum & pallidisetum & Funck & Mountain Haircap & FT \\
\hline Bryophyte & Polytrichaceae & Polytrichum & piliferum & Hedw. & Bristly Haircap & $\mathrm{T}$ \\
\hline Bryophyte & Porellaceae & Porella & pinnata & $\mathrm{L}$. & Pinnate Porella & $\mathrm{F}$ \\
\hline Bryophyte & Porellaceae & Porella & platyphylla & (L.) Pfeiff. & Porella liverwort & $\mathrm{F}$ \\
\hline Bryophyte & Hypnaceae & Pseudotaxiphyllum & distichaeceum & (Mitt.) Iwats. & Spreading Silk-moss & FBT \\
\hline Bryophyte & Hypnaceae & Pseudotaxiphyllum & elegans & (Brid.) Iwats. & Elegant Silk-moss & FBT \\
\hline Bryophyte & Ptilidiaceae & Ptilidium & pulcherrimum & (G. Web.) Hampe & & $\mathrm{F}$ \\
\hline Bryophyte & Hypnaceae & Pylaisiadelpha & tenuirostre & (Sull.) Buck & & FBT \\
\hline Bryophyte & Hypnaceae & Pylaisiella & polyantha & (Hedw.) Grout & & $\mathrm{T}$ \\
\hline
\end{tabular}




\begin{tabular}{|c|c|c|c|c|c|c|}
\hline Bryophyte & Dicranaceae & Rhabdoweisia & crispata & (With.) Lindb. & Toothed Streak-moss & FBT \\
\hline Bryophyte & Scapaniaceae & Scapania & nemorea & (L.) Grolle & Grove Earwort & FB \\
\hline Bryophyte & Scapaniaceae & Scapania & undulata & (L.) Dum. & & $\mathrm{F}$ \\
\hline Bryophyte & Grimmiaceae & Schistidium & apocarpum & (Hedw.) Bruch \& Schimp. & & FBT \\
\hline Bryophyte & Sematophyllaceae & Sematophyllum & demissum & (Wilson) Mitt. & Little Bubble-moss & FBT \\
\hline Bryophyte & Brachytheciaceae & Steerecleus & serrulatus & (Hedw.) H. Rob. & Steere's Feather-moss & BT \\
\hline Bryophyte & Tetraphidaceae & Tetraphis & pellucida & Hedw. & Four-tooth moss & $\mathrm{F}$ \\
\hline Bryophyte & Leskeaceae & Thuidium & delicatulum & (Hedw.) Schimp. & Delicate Fern-moss & BT \\
\hline Bryophyte & Pottiaceae & Tortella & humulis & (Hedwig) Jennings, Man. & & $\mathrm{T}$ \\
\hline
\end{tabular}


Appendix Table 3. 3: Cliff face species by frequency of occurrence

\begin{tabular}{|c|c|c|c|c|c|c|c|}
\hline Vascular species & $\begin{array}{c}\text { No. sites } \\
\text { recording / } \\
\text { observations }\end{array}$ & Lichen species & $\begin{array}{c}\text { No. } \\
\text { observations }\end{array}$ & $\begin{array}{l}\text { No. sites } \\
\text { recording }\end{array}$ & Bryophyte species & $\begin{array}{c}\text { No. } \\
\text { observations }\end{array}$ & $\begin{array}{l}\text { No. sites } \\
\text { recording }\end{array}$ \\
\hline Asplenium montanum & 58 & unknown crust & 249 & 104 & Leucobryum glaucum & 84 & 60 \\
\hline Betula lenta & 55 & Lasallia pennsylvanica & 151 & 83 & Dicranella heteromalla & 43 & 41 \\
\hline Acer rubrum & 37 & Physcia subtilis & 146 & 78 & Pseudotaxiphyllum elegans & 58 & 41 \\
\hline Rhododendron maximum & 32 & Cladonia sp. & 108 & 75 & Campylopus tallulensis & 47 & 40 \\
\hline Rubus sp. & 30 & Lasallia papulosa & 125 & 74 & Rhabdoweisia crispata & 29 & 21 \\
\hline Rhododendron catawbiense & 25 & Lepraria lobificans & 140 & 74 & Cephaloziella byssacea & 19 & 17 \\
\hline Danthonia spicata & 24 & Aspicilia cinerea & 109 & 72 & Andreaea rothii & 12 & 12 \\
\hline Kalmia latifolia & 20 & Chrysothrix susquehannensis & 134 & 72 & Dicranum fulvum & 12 & 12 \\
\hline Oxydendrum arboreum & 18 & Lepraria caesioalba & 120 & 71 & Diplophyllum apiculatum & 13 & 12 \\
\hline Carex sp. & 17 & Xanthoparmelia plittii & 106 & 65 & Pylaisiadelpha tenuirostre & 13 & 10 \\
\hline Clethra acuminata & 17 & Lepraria nomandinioides & 115 & 62 & Bryum sp. & 10 & 9 \\
\hline Pinus virginiana & 16 & Umbilicaria mammulata & 113 & 62 & Schistidium apocarpum & 12 & 9 \\
\hline Amelanchier arborea var. arborea & 15 & Phlyctis petraea & 85 & 56 & Brothera leana & 8 & 8 \\
\hline Dichanthelium dichotomum ssp. dichotomum & 15 & Dimelaena oreina & 86 & 47 & Grimmia pilifera & 11 & 8 \\
\hline Vaccinium pallidum & 14 & Lepraria caesiella & 53 & 40 & Bazzania trilobata & 6 & 6 \\
\hline Dryopteris intermedia & 13 & Lepraria sp. & 53 & 35 & Dicranum montanum & 6 & 6 \\
\hline Solidago sp. & 13 & Lepraria neglecta & 51 & 34 & Dicranum scoparium & 6 & 6 \\
\hline Agrostis perennans & 11 & Myelochroa obsessa & 56 & 34 & Homomallium adnatum & 7 & 6 \\
\hline Danthonia sericea & 10 & Caloplaca reptans & 45 & 32 & Hypnum imponens & 5 & 5 \\
\hline Eurybia divaricata & 10 & unknown dust lichen & 57 & 29 & Jamesoniella autumnalis & 5 & 5 \\
\hline Gaylussacia baccata & 10 & Flavoparmelia baltimorensis & 43 & 28 & Scapania nemorea & 6 & 5 \\
\hline Paulownia tomentosa & 8 & Parmeliopsis minarum & 38 & 26 & Unknown bryophyte & 5 & 5 \\
\hline Polystichum acrostichoides & 8 & Lepraria cryophila & 46 & 25 & Bryum capillare & 4 & 4 \\
\hline Smilax rotundifolia & 8 & Porpidia albocaerulescens & 29 & 23 & Platygyrium repens & 5 & 4 \\
\hline Asplenium pinnatifidum & 7 & Physcia millegrana & 38 & 22 & Polytrichum commune & 4 & 4 \\
\hline Heuchera americana & 7 & Xanthoparmelia conspersa & 35 & 22 & Pseudotaxiphyllum distichaceum & 5 & 4 \\
\hline Polypodium virginianum & 6 & Melanelia culbersonii & 28 & 20 & Pohlia nutans & 4 & 4 \\
\hline Quercus rubra & 6 & Rhizoplaca subdiscrepans & 23 & 18 & Bucklandiella heterostichum & 5 & 3 \\
\hline Smilax glauca & 6 & Buellia spuria & 23 & 16 & Leucobryum albidum & 3 & 3 \\
\hline Vaccinium stamineum & 6 & Xanthoparmelia angustiphylla & 23 & 15 & Leucolejeunea clypeata & 4 & 3 \\
\hline Parthenocissus quinquefolia & 5 & Chrysothrix insulizans & 14 & 14 & Pohlia sp. & 3 & 3 \\
\hline Coreopsis major & 4 & Cladonia squamosa & 16 & 13 & Polytrichum ohioense & 4 & 3 \\
\hline
\end{tabular}


Dichanthelium acuminatum ssp. columbianum Dichanthelium acuminatum ssp. fasciculatum

Epigaea repens

Hamamelis virginiana

Quercus stellata

Quercus velutina

Toxicodendron radicans

Tsuga canadensis

Juncus secundus

Rhus glabra

Sassafras albidum

Ulmus americana

Acer pensylvanicum

Asplenium platyneuron

Carex tonsa var. rugosperma

Circaea sp.

Dichanthelium boscii

Dichanthelium commutatum ssp. ashei

Dichanthelium linearifolium

Fagus grandifolia

Goodyera repens

Hypericum mutilum

Juniperus virginiana var. virginiana

Liriodendron tulipifera

Mitchella repens

Nyssa sylvatica

Pinus rigida

Poa cuspidata

Quercus prinus

Schizachyrium scoparium var. scoparium

Viburnum acerifolium

Agrostis scabra

Andropogon gerardii

Betula alleghaniensis var. alleghaniensis

Bidens vulgate

Carex laxiflora
Dimelaena oreina

Rhizocarpon grande

Punctelia subrudecta

Porpidia subsimplex

Punctelia rudecta

Aspicilia caesiocinere

Cladonia macilenta

Diploschistes scruposus

Cladonia chlorophaea complex

Parmeliopsis horrescens

Imshaugia aleurites

Lecanora thysanophora

Amandinea punctata

Aspicilia laevata

Porpidia crustulata

Psilolechia lucida

Trapeliopsis granulosa

Umbilicaria muehlenbergii

Cladonia caroliniana

Dirinaria frostii

unknown foliose lichen

Acarospora fuscata

Buellia vernicoma

Chrysothrix xanthina

Cladonia pleurota

Flavoparmelia caperata

Hypocenomyce scalaris

Lepraria elobata

Porpidia sp.

Punctelia missouriensis

Ramalina intermedia

Ramalina pollinaria

Scoliciosporum umbrinum

Segestria leptalea

Xanthoparmelia australasica

Anisomeridium distans

\begin{tabular}{|c|c|c|}
\hline Porella pinnata & 4 & 3 \\
\hline Calypogeia fissa & 3 & 2 \\
\hline Diphyscium foliosum & 3 & 2 \\
\hline lontoschisma prostratum & 3 & 1 \\
\hline Frullania asagrayana & 2 & 2 \\
\hline Hedwigia ciliata & 2 & 2 \\
\hline Lejeunea ulicina & 2 & 2 \\
\hline Scapania undulata & 2 & 2 \\
\hline Calypogeia sullivantii & 2 & 1 \\
\hline Anomodon attenuatus & 1 & 1 \\
\hline Atrichum angustatum & 1 & 1 \\
\hline Brotherella recurvans & 1 & 1 \\
\hline ryoandersonia illecebra & 1 & 1 \\
\hline Calypogeia muelleriana & 1 & 1 \\
\hline ephaloziella spinicaulis & 1 & 1 \\
\hline Entodon brevisetus & 1 & 1 \\
\hline Fissidens taxifolius & 1 & 1 \\
\hline Grimmia laevigata & 1 & 1 \\
\hline ygroamblystegium tenax & 1 & 1 \\
\hline Lejeunea ruthii & 1 & 1 \\
\hline Pellia epiphylla & 1 & 1 \\
\hline Platydictya subtilis & 1 & 1 \\
\hline olytrichum pallidisetum & 1 & 1 \\
\hline Porella platyphylla & 1 & 1 \\
\hline Ptilidium pulcherrimum & 1 & 1 \\
\hline ematophyllum demissum & 1 & 1 \\
\hline Tetraphis pellucida & 1 & 1 \\
\hline
\end{tabular}




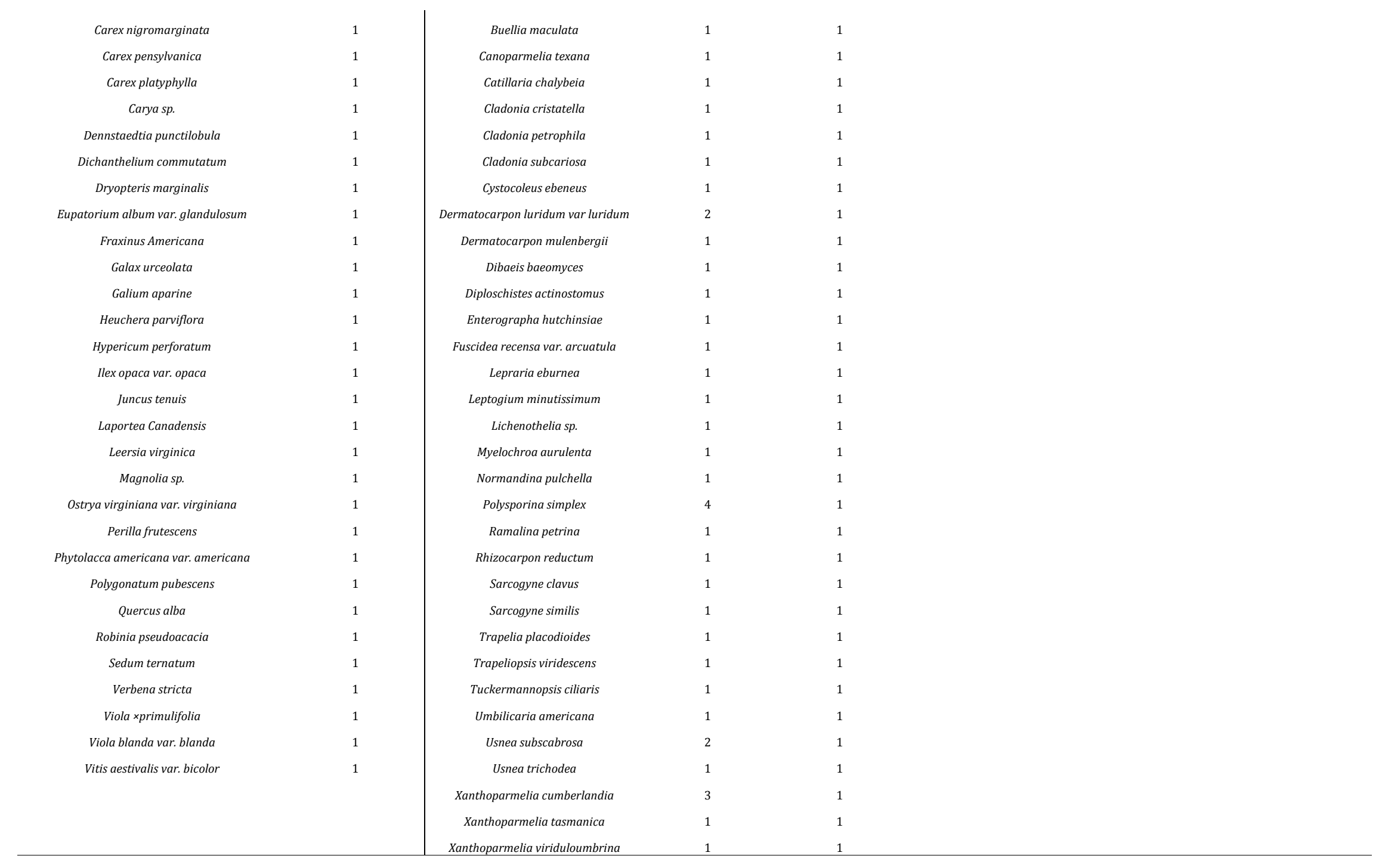




\section{Appendix Table 3. 4: Rare species or species of special interest}

\begin{tabular}{|c|c|c|}
\hline Taxon & Scientific Name & Notes \\
\hline Vascular & Carex appalachica & $\begin{array}{l}\text { tracked rare, but possibly more common. S2 (Six to } 20 \text { documented occurrences, or few remaining individuals within the state. Very rare and imperiled; or because of some } \\
\text { factor(s) making it vulnerable to extirpation.) }\end{array}$ \\
\hline Vascular & Carex nigromarginata & tracked rare. S3: (Twenty-one to 100 documented occurrences. May be somewhat vulnerable to extirpation) \\
\hline Vascular & Carex tonsa var. rugosperma & $\begin{array}{l}\text { tracked rare S2/S3 } \\
\text { tracked rare. S1: (Five or fewer documented occurrences, or very few remaining individuals within the state. Extremely rare and critically imperiled; or because of some }\end{array}$ \\
\hline Vascular & Danthonia sericea & factor(s) making it especially vulnerable to extirpation.) \\
\hline Vascular & Dichanthelium acuminatum ssp. columbianum & tracked rare S1 \\
\hline Lichen & Anisomeridium distans & Status in WV unknown; no previous records; frequent on rock in eastern US \\
\hline Lichen & Aspicilia laevata & Status unknown in WV; no previous records; genus needs revision \\
\hline Lichen & Buellia badia & Status unknown in WV; no previous records; unknown distribution \\
\hline Lichen & Buellia maculata & Status in WV unknown; no previous records; common in southeastern US \\
\hline Lichen & Buellia spuria & Status in WV unknown; no previous records; common in eastern US \\
\hline Lichen & Buellia vernicoma & Status in WV unknown; no previous records; frequent in eastern US \\
\hline Lichen & Caloplaca reptans & Status unknown; new species to be yet described; common in eastern US \\
\hline Lichen & Canoparmelia amabilis & Status unknown in WV; 1 previous record; newly separated from Canoparmelia caroliniana \\
\hline Lichen & Catillaria chalybeia & Status in WV unknown; no previous records; wide spread in eastern US \\
\hline Lichen & Chrysothrix insulizans & Rare and unusual in WV; known from 1 additional county; a newly described species \\
\hline Lichen & Chrysothrix susquehannensis & Rare and unusual in WV; known only from 1 site in Pennsylvania; a newly described species \\
\hline Lichen & Chrysothrix xanthina & Status in WV unknown; 3 previous records; widely distributed but not common. \\
\hline Lichen & Cladonia atlantica & Status unknown in WV; 1 previous record; early records of Cladonia squamosa may contain this species \\
\hline Lichen & Cladonia beaumontii & Status unknown in WV; 2 previous records; early records of Cladonia squamosa may contain this species \\
\hline Lichen & Cladonia didyma & Infrequent in $\mathrm{WV} ; 3$ previous records \\
\hline Lichen & Cladonia petrophila & Status unknown in WV; 2 previous records; may be more common than records indicate since it is usually sterile \\
\hline Lichen & Cladonia turgida & Probably rare in WV; 1 previous, historical record; a northeastern species \\
\hline Lichen & Cystocoleus ebeneus & Rare and unusual in WV; known from only a few sites in eastern US \\
\hline Lichen & Enterographa hutchinsiae & Rare and unusual; known from only a few sites in eastern US; grows on sandstone \\
\hline Lichen & Lasallia pennsylvanica & Infrequent in WV; 6 previous records; grows on rock outcrops and boulders \\
\hline Lichen & Lepraria cryophila & Status unknown in WV; no previous records; newly described species \\
\hline Lichen & Lepraria eburnea & Status unknown in WV; no previous records; newly described species; identification may be in error \\
\hline Lichen & Lepraria elobata & Status unknown in WV; no previous records; newly described species; identification may be in error \\
\hline Lichen & Leptogium minutissimum & Status unknown in WV; small, rarely collected species \\
\hline Lichen & Melanelia culbersonii & Infrequent in WV; 3 previous records \\
\hline Lichen & Normandina pulchella & Status unknown in WV; 1 previous record; often overlooked among mosses and other lichen species. \\
\hline Lichen & Parmeliopsis horrescens & Infrequent in WV; 3 previous records; more common in the southeastern states \\
\hline Lichen & Ramalina petrina & Considered rare in WV; no previous records; an uncommon species of the Appalachian Region \\
\hline Lichen & Ramalina pollinaria & Status unknown in WV; 2 previous records; identifications need checked against Ramalina obtusata \\
\hline Lichen & Rhizocarpon grande & Status in WV unknown; 2 previous records; often found in sterile condition \\
\hline
\end{tabular}




\begin{tabular}{|c|c|c|}
\hline Lichen & Rhizoplaca subdiscrepans & Status unknown for WV; 2 previous records; common northeastern species \\
\hline Lichen & Rinodina siouxiana & Inventory specimen found on coal; no previous records; status in WV unknown \\
\hline Lichen & Segestria leptalea & Status unknown in WV; 1 previous record; possibly overlooked due to very small size perithecia \\
\hline Lichen & Trapelia placodioides & Status unknown in WV; 1 previous record; a northeastern species \\
\hline Lichen & Trapeliopsis granulosa & Status unknown in WV; 4 previous records; a common soil lichen in northeastern US \\
\hline Lichen & Trapeliopsis viridescens & Status unknown in $\mathrm{WV} ; 3$ previous records; a common eastern species \\
\hline Lichen & Umbilicaria americana & Rare in WV; 2 previous records, both historical; a northern species of New England and Canada \\
\hline Lichen & Usnea subscabrosa & Status unknown in WV; no previous records; a species of the southeastern states \\
\hline Lichen & Usnea trichodea & Probably uncommon in WV; 1 previous record; a species of the eastern coastal states \\
\hline Lichen & Xanthoparmelia angustiphylla & Infrequent in $\mathrm{WV} ; 3$ previous records \\
\hline Lichen & Xanthoparmelia australasica & Infrequent in WV; 1 previous record \\
\hline Lichen & Xanthoparmelia tasmanica & Infrequent in $\mathrm{WV} ; 6$ previous records \\
\hline Lichen & Xanthoparmelia viriduloumbrina & Infrequent in WV; 4 previous records \\
\hline Bryophyte & Andreaea rothii & Uncommon; characteristic of seepy non-calcareous cliffs; endemic to WV \\
\hline Bryophyte & Brothera leana & Relatively rare in eastern North America \& in WV; found on moist sandstone ledges and caves \\
\hline Bryophyte & Bucklandiella heterostichum & Uncommon to WV; northern plant on exposed or shaded acidic rock that extends into mountains \\
\hline Bryophyte & Campylopus tallulensis & Uncommon except on sandstone ridgetops in Appalachians; coastal plain affinities \\
\hline Bryophyte & Cephaloziella spinicaulis & Uncommon to WV \\
\hline Bryophyte & Dicranum condensatum & Rare to WV; a Coastal Plain species flourishing on dry sandy ridges (as in Red R Gorge of KY) \\
\hline Bryophyte & Dicranum spurium & Uncommon in WV; 2 WV collections; dry acidic rock \\
\hline Bryophyte & Entodon brevisetus & Uncommon in WV; tree bases, uncommon in Eastern North America, disjunctive to Asia \\
\hline Bryophyte & Lejeunea ruthii & Uncommon in WV;: moist shaded rocks in ravines; Appalachian endemic \\
\hline Bryophyte & Rhabdoweisia crispata & Relic species persisting in gorges and ravines; moist shaded acidic sandstone \\
\hline
\end{tabular}




\section{Figures}

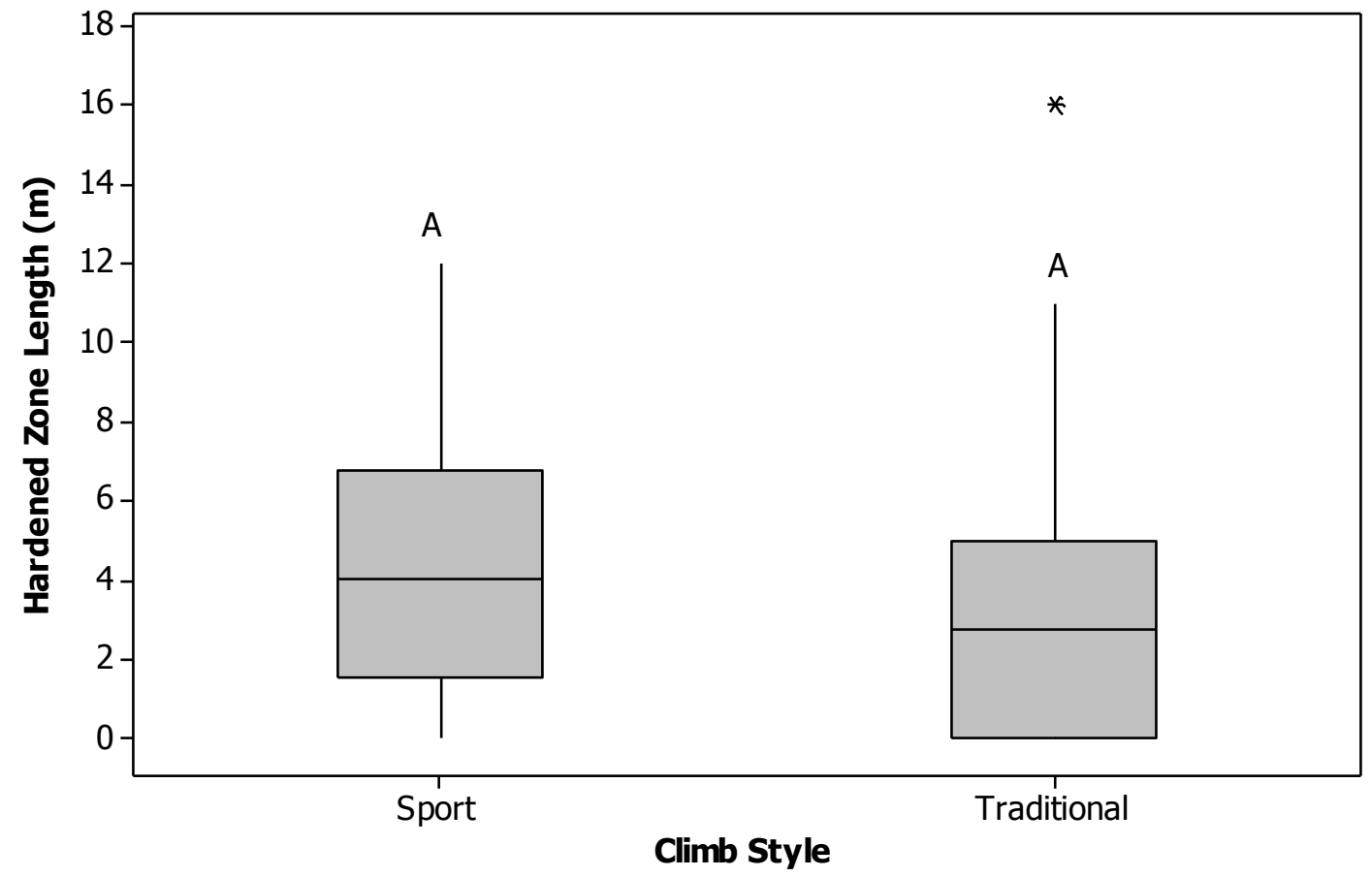

Appendix Figure 2. 1: Cliff base hardened zone length $(\mathrm{m})$ compared by climb style (e.g., sport and traditional). Statistical significance is calculated using Kruskal-Wallis test. Columns that share a letter code are not significantly different from one another at $\alpha=0.05$ 

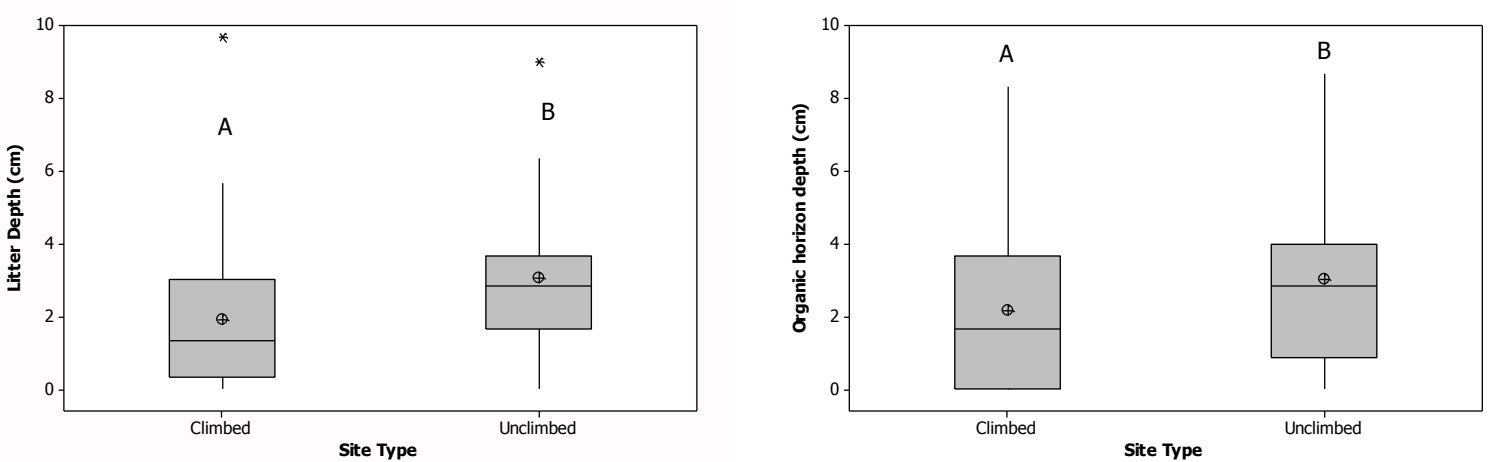

Appendix Figure 2. 2: Litter and organic soils depths at cliff base compared by site type. Columns that share a letter code are not significantly different from one another at $\alpha=0.05$ 


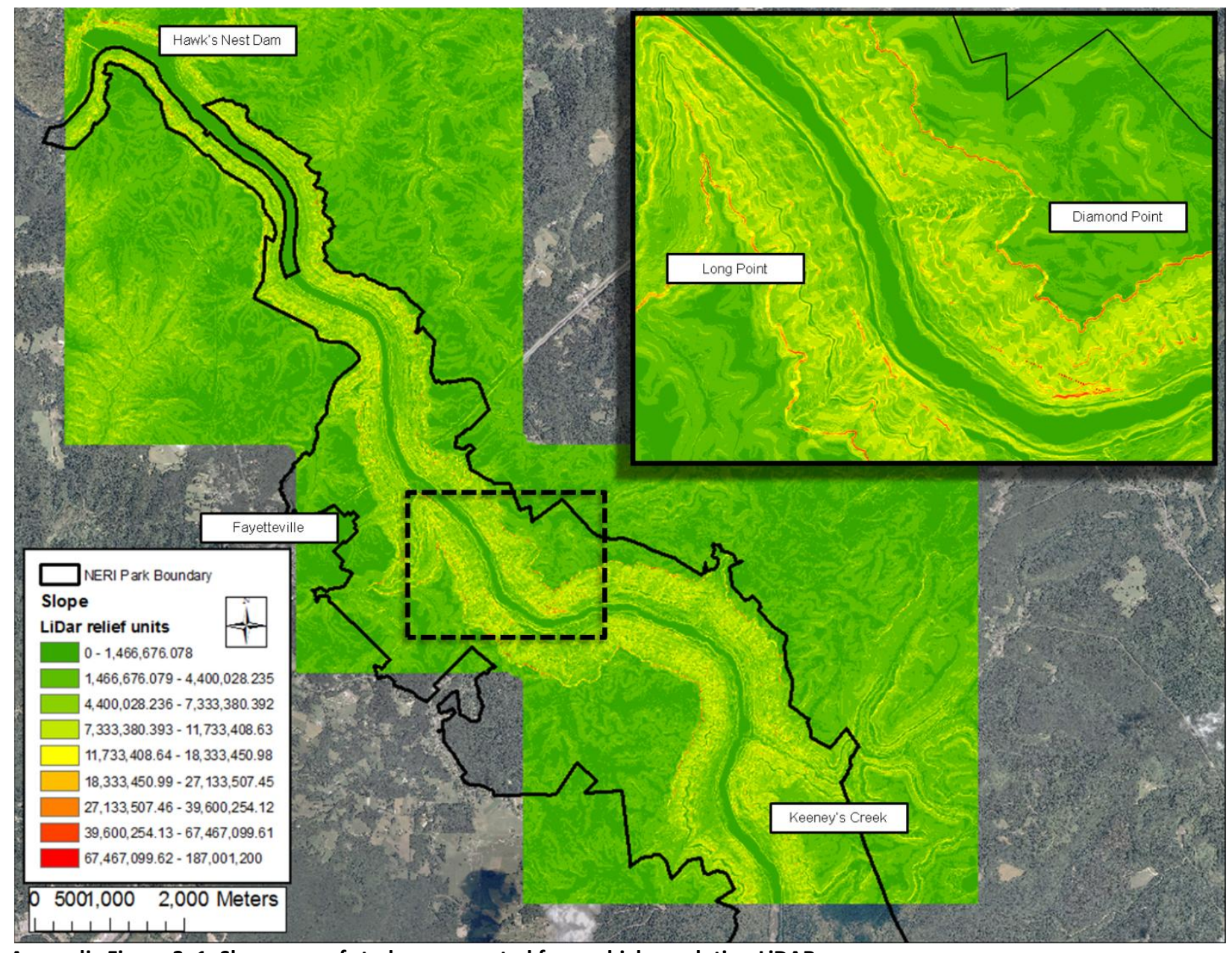

Appendix Figure 3. 1: Slope map of study area created from a high resolution LiDAR 


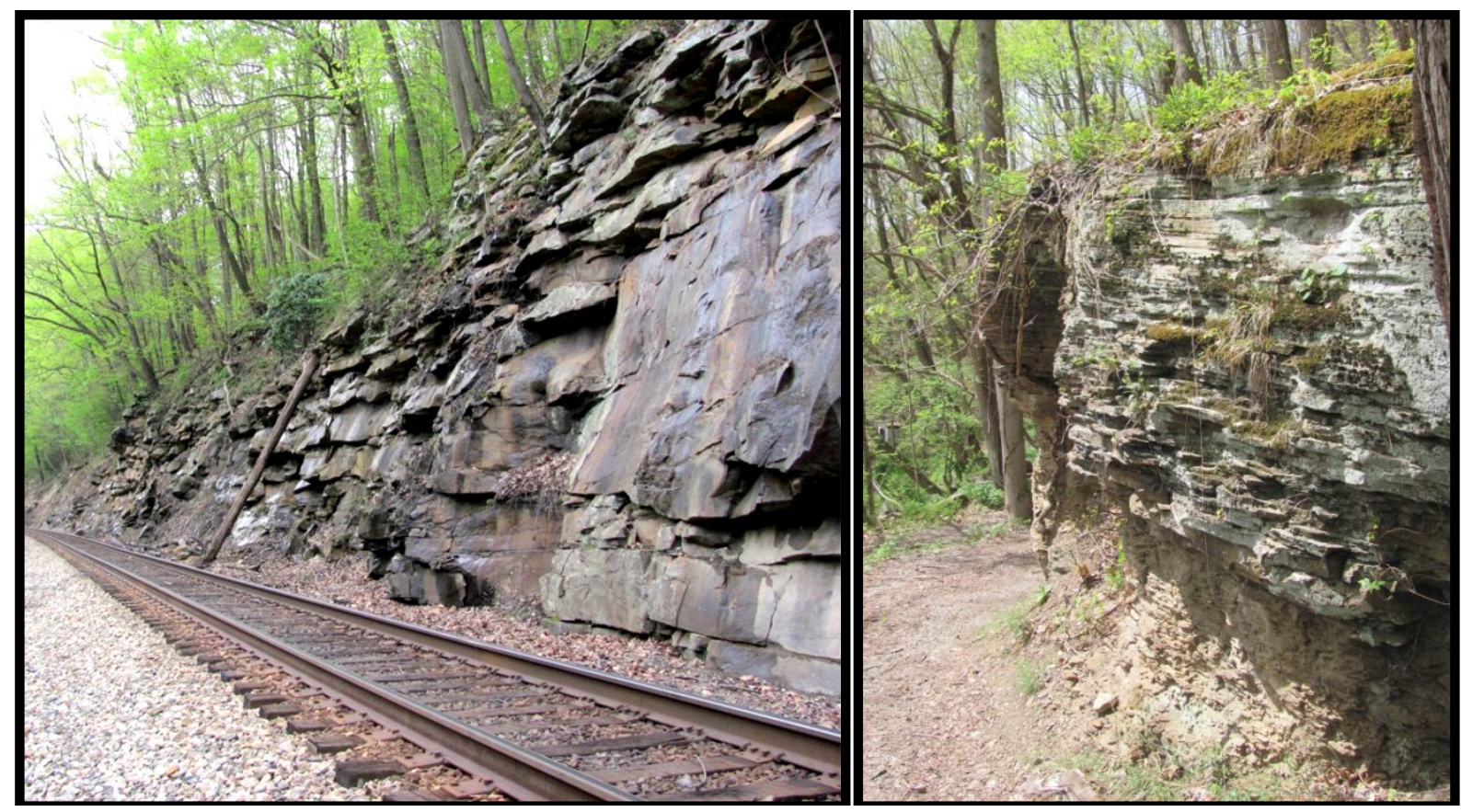

Appendix Figure 3. 2: Two cliffs partially or fully formed by manmade processes. 
Appendix Figure 3. 3: Stepwise regression using Minitab software. Predictors: cliff angle, macrotopographic frequency, microtopographic frequency and volume, aspect and elevation. Response: species richness by taxonomic group

\section{Stepwise Regression: Total Species Richness \\ Alpha-to-Enter: 0.15 Alpha-to-Remove: 0.15 \\ Response is Total Species Richness on 7 predictors, with $\mathrm{N}=147$

$\begin{array}{lrrr}\text { Step } & 1 & 2 & 3 \\ \text { Constant } & 53.98 & 50.40 & 41.69 \\ \text { Cliff_Angle_Degrees } & -0.415 & -0.348 & -0.264 \\ \text { T-Value } & -8.33 & -6.29 & -4.38 \\ \text { P-Value } & 0.000 & 0.000 & 0.000 \\ & & & \\ \text { Macro_Roof_freq } & & -2.15 & -2.77 \\ \text { T-Value } & & -2.58 & -3.32 \\ \text { P-Value } & & 0.011 & 0.001 \\ & & & \\ \text { Macro_Ledge_freq } & & & 2.14 \\ \text { T-Value } & & & 3.09 \\ \text { P-Value } & & & 0.002 \\ & 7.23 & 7.09 & 6.89 \\ \text { S } & 32.35 & 35.34 & 39.39 \\ \text { R-Sq } & 31.88 & 34.45 & 38.12 \\ \text { R-Sq(adj) } & 18.5 & 13.3 & 5.6 \\ \text { Mallows Cp } & & & \\ & & & \end{array}$

\section{Stepwise Regression: Vascular Species Richness}

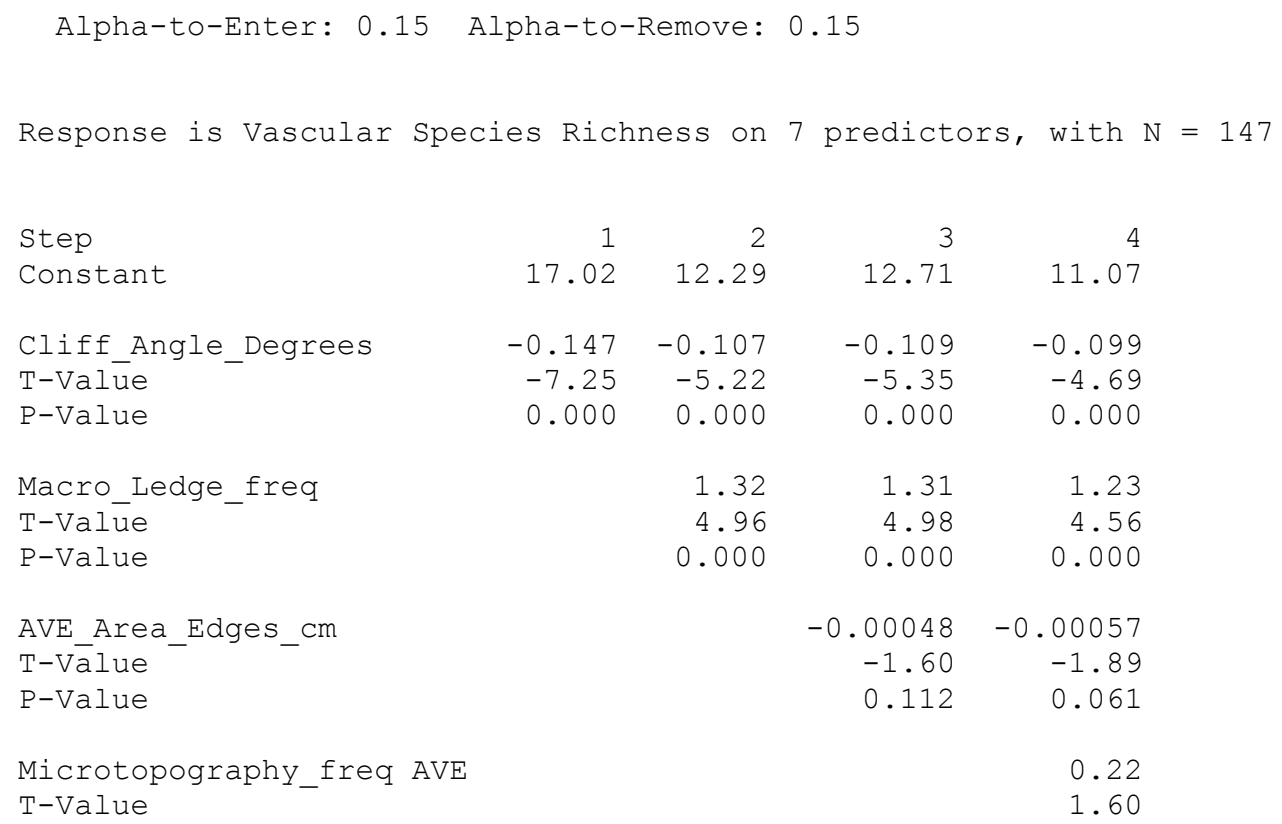




$\begin{array}{lrrrr}\text { P-Value } & & & & 0.111 \\ \text { S } & 2.94 & 2.72 & 2.71 & 2.70 \\ \text { R-Sq } & 26.59 & 37.30 & 38.40 & 39.49 \\ \text { R-Sq(adj) } & 26.08 & 36.43 & 37.10 & 37.79 \\ \text { Mallows Cp } & 26.9 & 4.1 & 3.5 & 3.0\end{array}$

\section{Stepwise Regression: Bryophyte Species Richness}

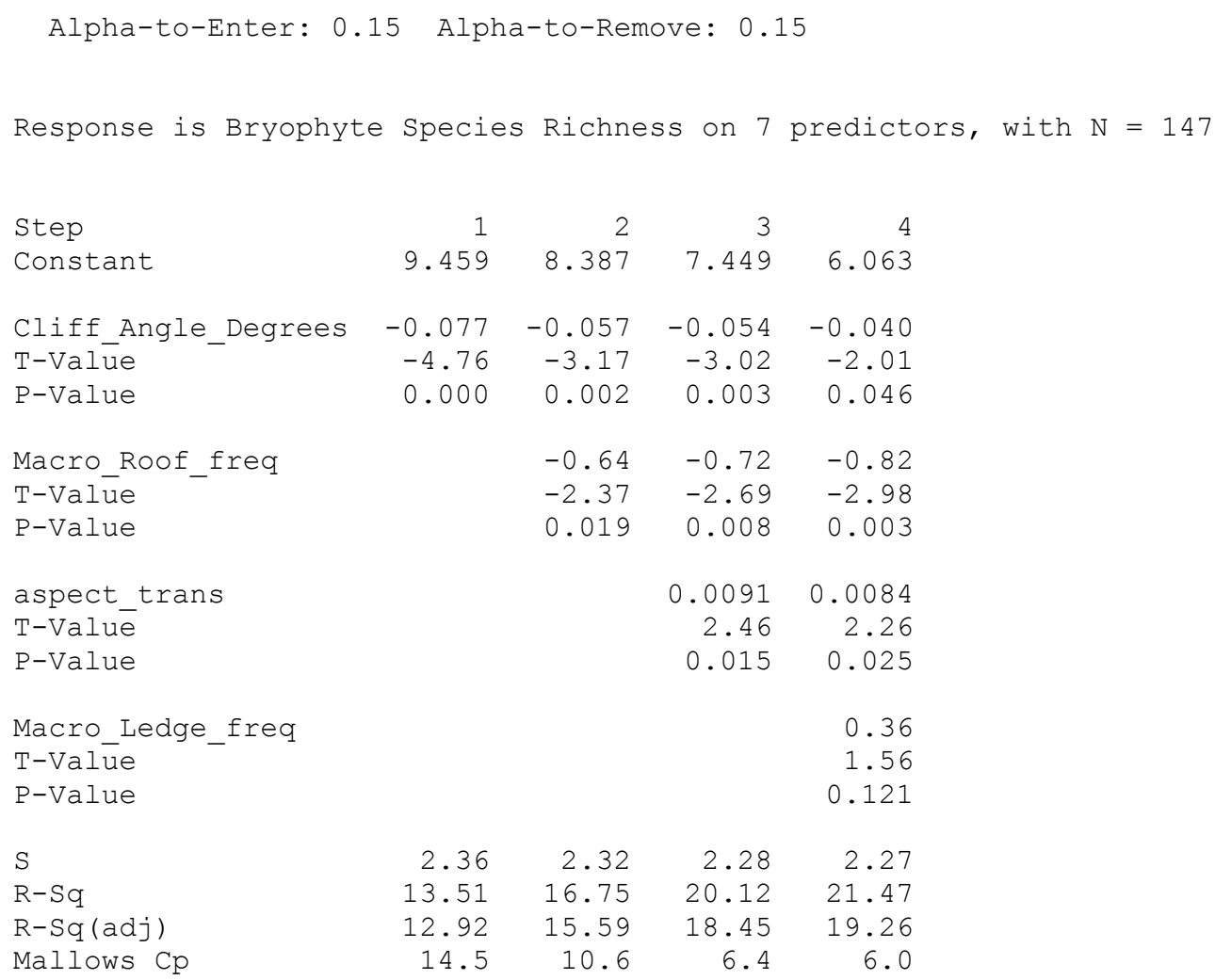

\section{Stepwise Regression: Lichen Species Richness}

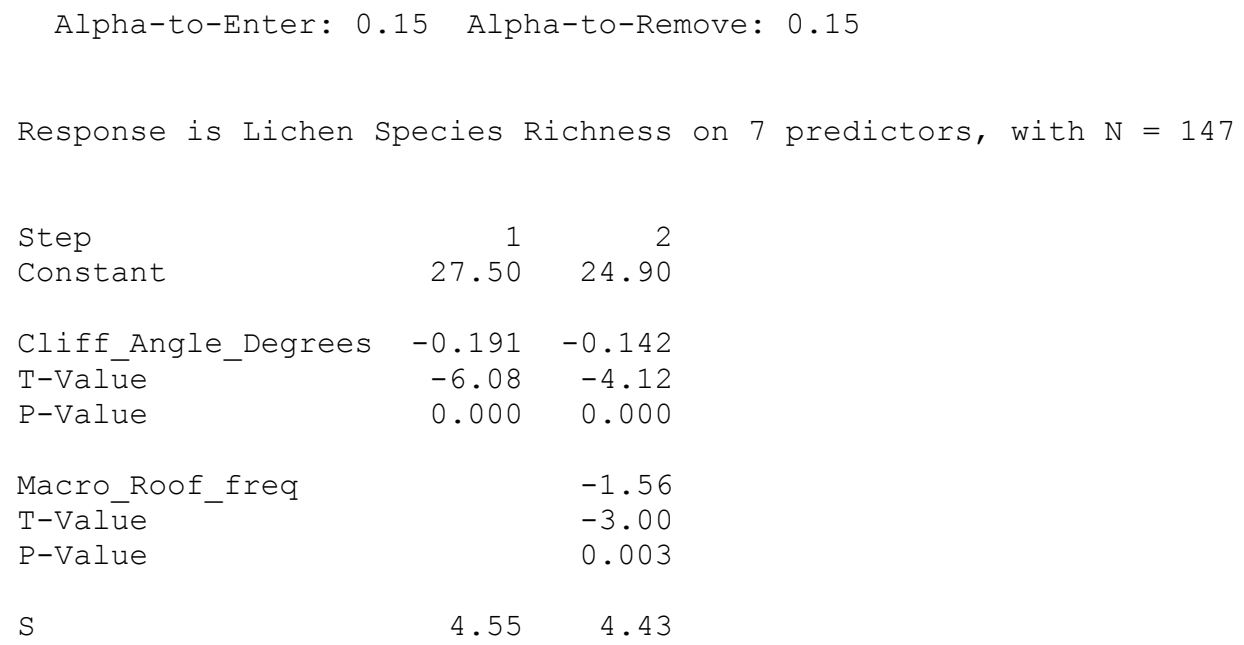


$\mathrm{R}-\mathrm{Sq}$

$\mathrm{R}-\mathrm{Sq}$ (adj)

Mallows $\mathrm{Cp}$
20.31

19.76

9.3

25.00

23.96

2.4 
Appendix Figure 3. 4: Multiple linear regression for species richness by taxonomic group (response) using significant predictors from a stepwise regression using Minitab software

\section{Regression Analysis: Total Species Richness}

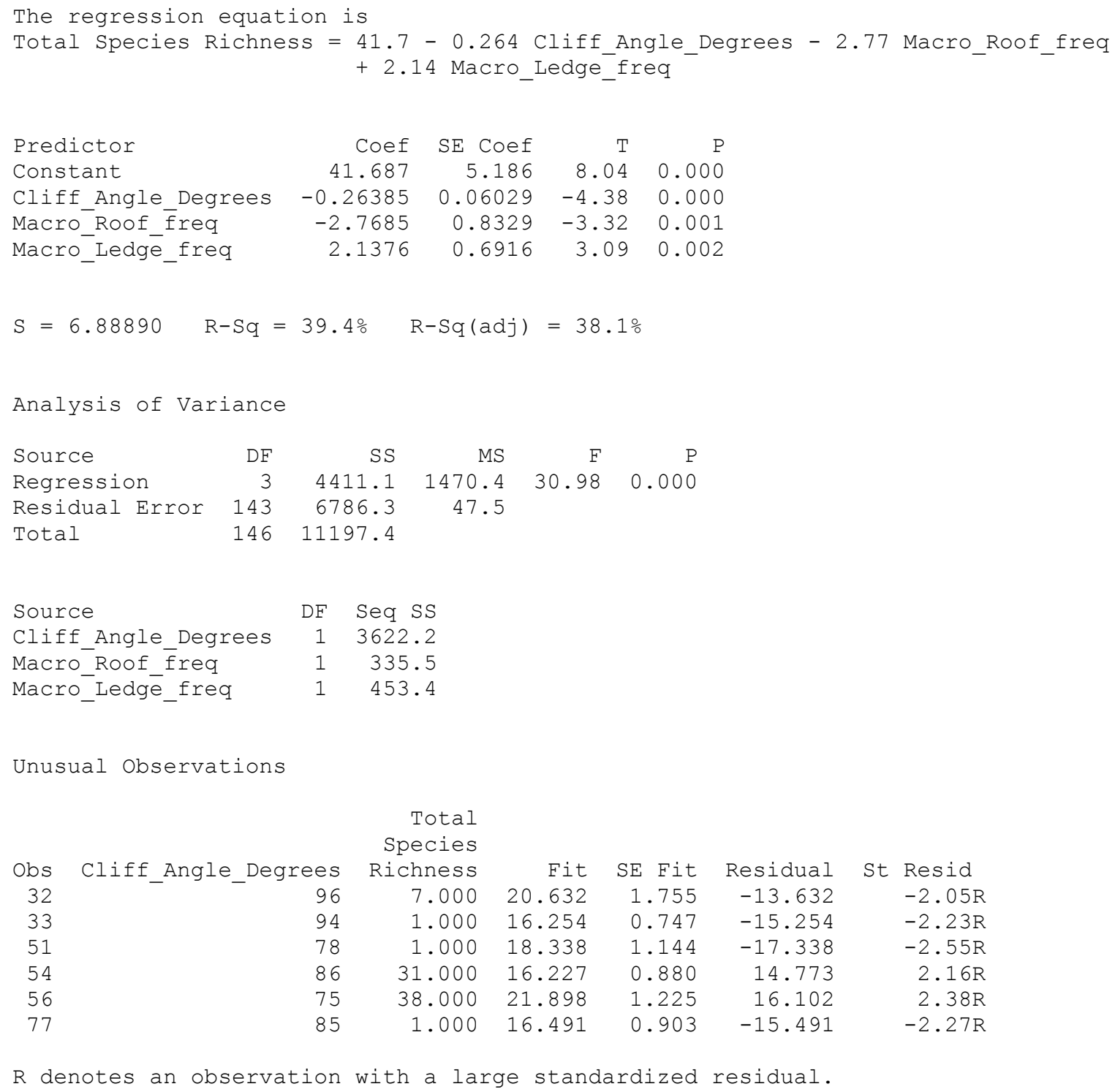

\section{Regression Analysis: Vascular Spe versus Cliff_Angle_, Macro_Ledge}

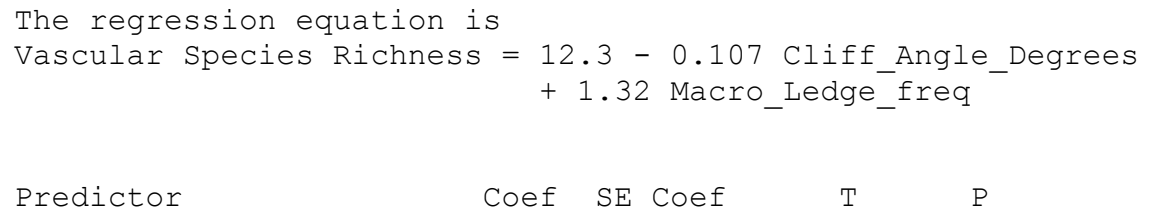




\begin{tabular}{|c|c|c|c|c|c|c|c|}
\hline \multirow{3}{*}{\multicolumn{2}{|c|}{$\begin{array}{l}\text { Constant } \\
\text { Cliff_Angle_Degrees } \\
\text { Macro_Ledge_freq }\end{array}$}} & \multicolumn{2}{|c|}{12.287} & \multicolumn{3}{|l|}{1.895} & 0.000 \\
\hline & & \multicolumn{2}{|c|}{-0.10675} & 0.02046 & -5.2 & & 0.000 \\
\hline & & \multicolumn{2}{|c|}{1.3167} & 0.2655 & 4.9 & & 0.000 \\
\hline$S=2.72499$ & $\mathrm{R}-\mathrm{Sq}=$ & 37. & & $R-S q(a d j)$ & $=36$. & & \\
\hline \multicolumn{8}{|c|}{ Analysis of Variance } \\
\hline Source & $\mathrm{DF}$ & & SS & MS & $\mathrm{F}$ & & $\mathrm{P}$ \\
\hline Regression & 2 & & 6.02 & 318.01 & 42.83 & & .000 \\
\hline Residual Error & 144 & 106 & 9.28 & 7.43 & & & \\
\hline Total & 146 & 170 & 5.31 & & & & \\
\hline \multirow{3}{*}{\multicolumn{2}{|c|}{$\begin{array}{l}\text { Source } \\
\text { Cliff_Angle_Degrees } \\
\text { Macro_Ledge_freq }\end{array}$}} & \multirow{3}{*}{\multicolumn{3}{|c|}{$\begin{array}{rl}\text { DF } & \text { Seq SS } \\
1 & 453.44 \\
1 & 182.58\end{array}$}} & & & \\
\hline & & & & & & & \\
\hline & & & & & & & \\
\hline
\end{tabular}

\begin{tabular}{|c|c|c|c|c|c|c|}
\hline & & $\begin{array}{r}\text { Vascular } \\
\text { Species }\end{array}$ & & & & \\
\hline Obs & Cliff_Angle_Degrees & Richness & Fit & SE Fit & Residual & St Resid \\
\hline 12 & $-\quad-\quad 124$ & 1.000 & -0.949 & 0.745 & 1.949 & $0.74 \mathrm{x}$ \\
\hline 18 & 75 & 1.000 & 6.915 & 0.359 & -5.915 & $-2.19 R$ \\
\hline 28 & 90 & 11.000 & 3.997 & 0.238 & 7.003 & $2.58 R$ \\
\hline 61 & 83 & 10.000 & 3.427 & 0.367 & 6.573 & $2.43 R$ \\
\hline 70 & 121 & 2.000 & -0.629 & 0.690 & 2.629 & $1.00 \mathrm{x}$ \\
\hline 122 & 84 & 9.000 & 3.320 & 0.358 & 5.680 & $2.10 \mathrm{R}$ \\
\hline 124 & 72 & 0.000 & 5.918 & 0.366 & -5.918 & $-2.19 R$ \\
\hline 130 & 80 & 12.000 & 6.381 & 0.338 & 5.619 & $2.08 \mathrm{R}$ \\
\hline 131 & 65 & 14.000 & 7.982 & 0.470 & 6.018 & $2.24 R$ \\
\hline 133 & 63 & 14.000 & 8.196 & 0.500 & 5.804 & $2.17 R$ \\
\hline 145 & 72 & 14.000 & 7.235 & 0.385 & 6.765 & $2.51 R$ \\
\hline 146 & 90 & 12.000 & 5.313 & 0.385 & 6.687 & $2.48 R$ \\
\hline
\end{tabular}

$R$ denotes an observation with a large standardized residual.

$\mathrm{X}$ denotes an observation whose $\mathrm{X}$ value gives it large leverage.

\section{Regression Analysis: Bryophyte Sp versus Cliff_Angle_, aspect_trans, ...}

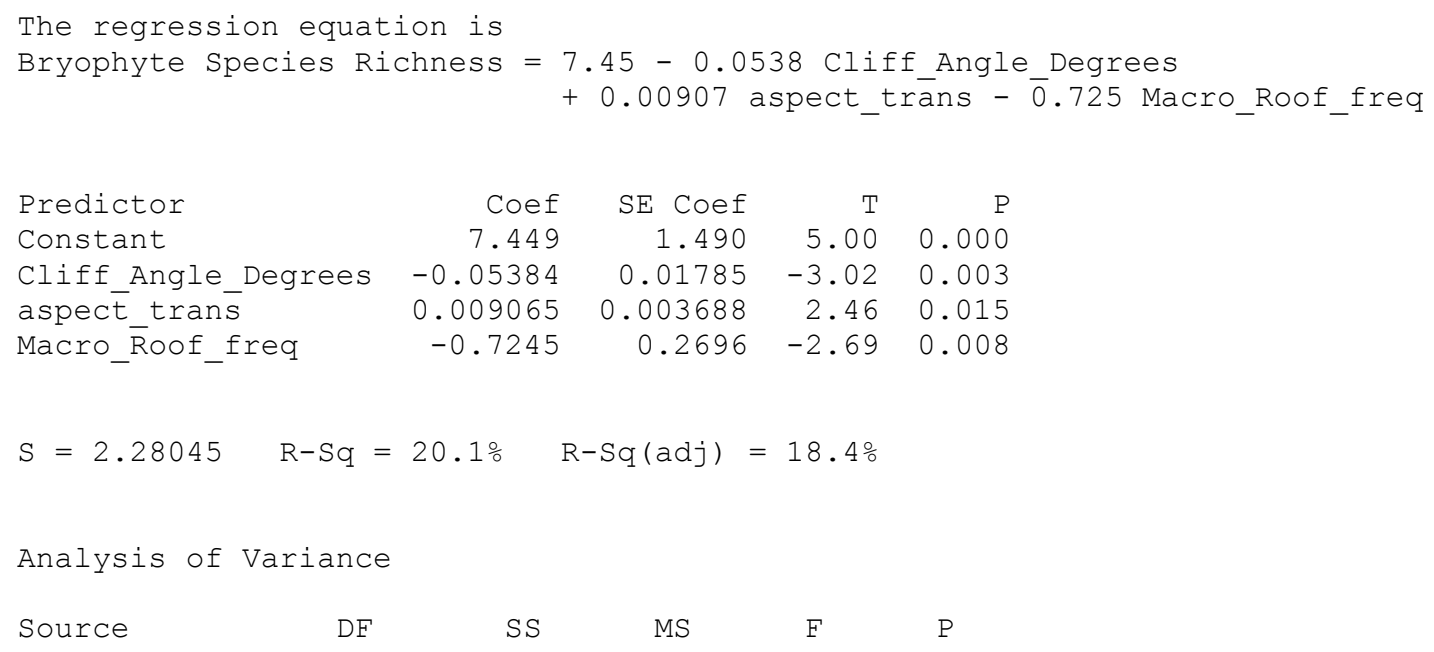




$\begin{array}{lrrrrr}\text { Regression } & 3 & 187.369 & 62.456 & 12.01 & 0.000 \\ \text { Residual Error } & 143 & 743.665 & 5.200 & & \\ \text { Total } & 146 & 931.034 & & \\ & & & & & \\ & & & & \\ \text { Source } & \text { DF } & \text { Seq SS } & \\ \text { Cliff_Angle_Degrees } & 1 & 125.825 \\ \text { aspect_trans } & 1 & 23.993 \\ \text { Macro_Roof_freq } & 1 & 37.551\end{array}$

Unusual Observations

\begin{tabular}{rrrrrrr}
\multicolumn{7}{c}{$\begin{array}{c}\text { Bryophyte } \\
\text { Species }\end{array}$} \\
Obs Cliff_Angle_Degrees & Richness & Fit & SE Fit & Residual & St Resid \\
56 & 75 & 9.000 & 3.792 & 0.337 & 5.208 & $2.31 \mathrm{R}$ \\
61 & 83 & 8.000 & 3.134 & 0.373 & 4.866 & $2.16 \mathrm{R}$ \\
65 & 72 & 10.000 & 3.826 & 0.375 & 6.174 & $2.74 \mathrm{R}$ \\
70 & 121 & 3.000 & 0.954 & 0.662 & 2.046 & $0.94 \mathrm{X}$ \\
111 & 98 & 7.000 & 1.993 & 0.374 & 5.007 & $2.23 \mathrm{R}$ \\
113 & 79 & 10.000 & 4.012 & 0.396 & 5.988 & $2.67 \mathrm{R}$ \\
142 & 99 & 8.000 & 1.721 & 0.338 & 6.279 & $2.78 \mathrm{R}$
\end{tabular}

$\mathrm{R}$ denotes an observation with a large standardized residual.

$\mathrm{X}$ denotes an observation whose $\mathrm{X}$ value gives it large leverage.

\section{Regression Analysis: Lichen Speci versus Cliff_Angle_, Macro_Roof_f}

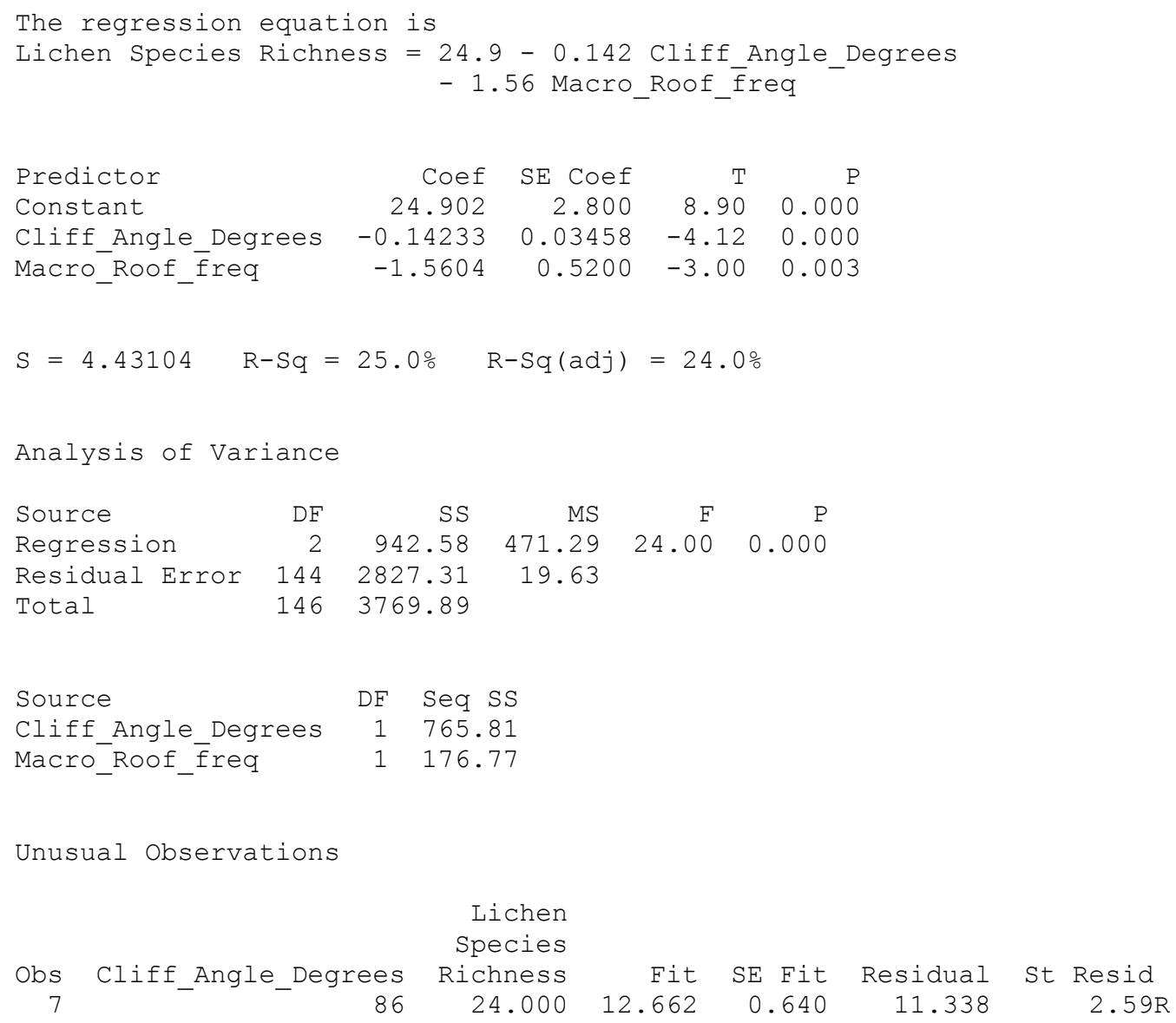




$\begin{array}{rrrrrrr}12 & 124 & 6.000 & 4.133 & 1.213 & 1.867 & 0.44 \mathrm{X} \\ 33 & 94 & 1.000 & 9.963 & 0.455 & -8.963 & -2.03 \mathrm{R} \\ 51 & 78 & 1.000 & 12.240 & 0.462 & -11.240 & -2.55 \mathrm{R} \\ 54 & 86 & 21.000 & 11.102 & 0.366 & 9.898 & 2.24 \mathrm{R} \\ 64 & 76 & 21.000 & 10.965 & 0.830 & 10.035 & 2.31 \mathrm{R} \\ 66 & 75 & 1.000 & 12.667 & 0.531 & -11.667 & -2.65 \mathrm{R} \\ 69 & 100 & 19.000 & 9.109 & 0.602 & 9.891 & 2.25 \mathrm{R} \\ 70 & 121 & 5.000 & 4.560 & 1.123 & 0.440 & 0.10 \mathrm{X} \\ 74 & 88 & 3.000 & 12.449 & 0.661 & -9.449 & -2.16 \mathrm{R} \\ 77 & 85 & 1.000 & 11.244 & 0.368 & -10.244 & -2.32 \mathrm{R} \\ 78 & 120 & 4.000 & 6.263 & 1.226 & -2.263 & -0.53 \mathrm{X}\end{array}$

$R$ denotes an observation with a large standardized residual.

$X$ denotes an observation whose $X$ value gives it large leverage. 


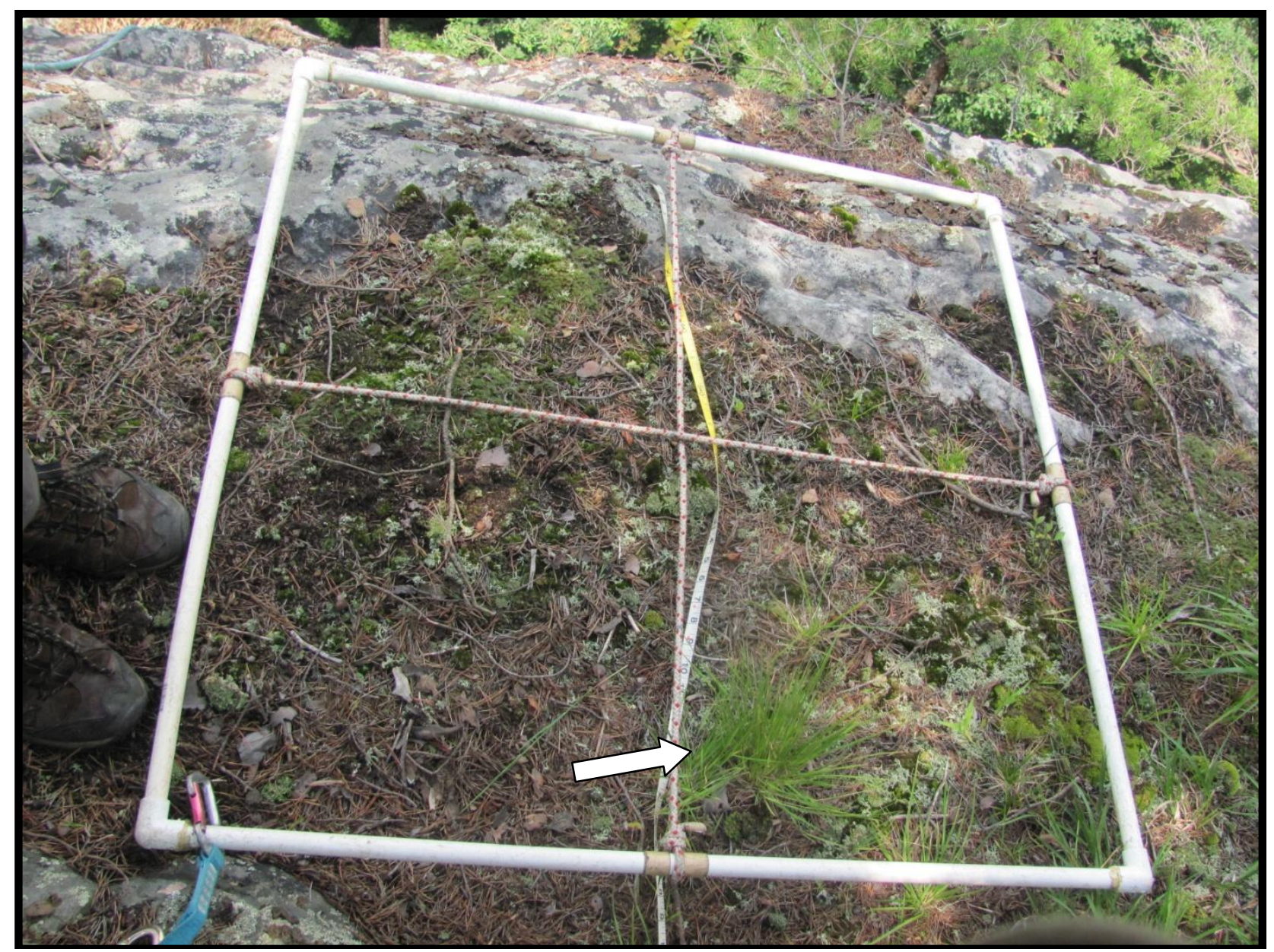

Appendix Figure 3. 5: Dichanthelium acuminatum (Sw.) Gould \& C.A. Clark ssp. columbianum established on the cliff top of a Nuttall Sandstone cliff (site N214) 


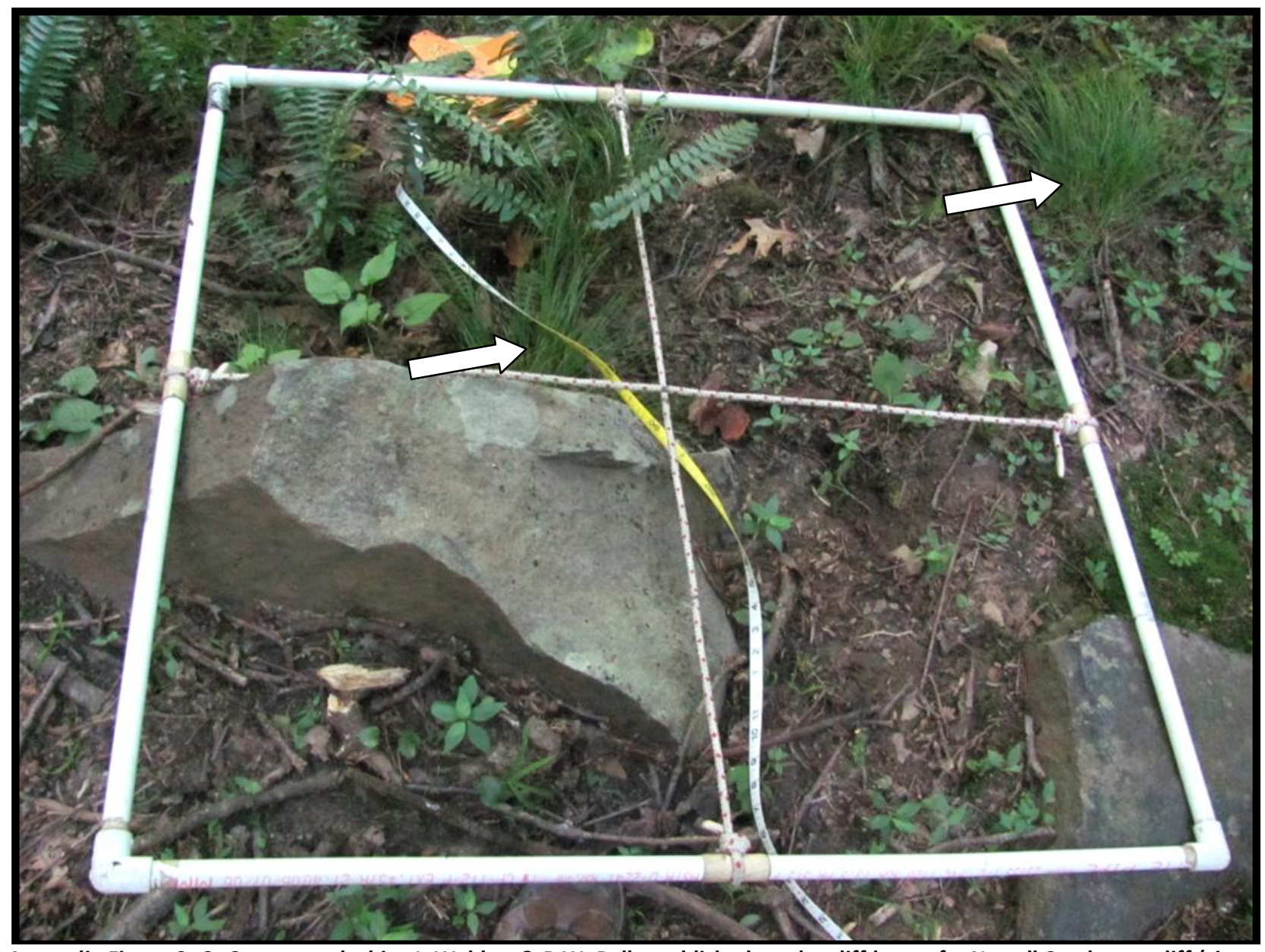

Appendix Figure 3. 6: Carex appalachica J. Webber \& P.W. Ball established on the cliff base of a Nuttall Sandstone cliff (site N49) 


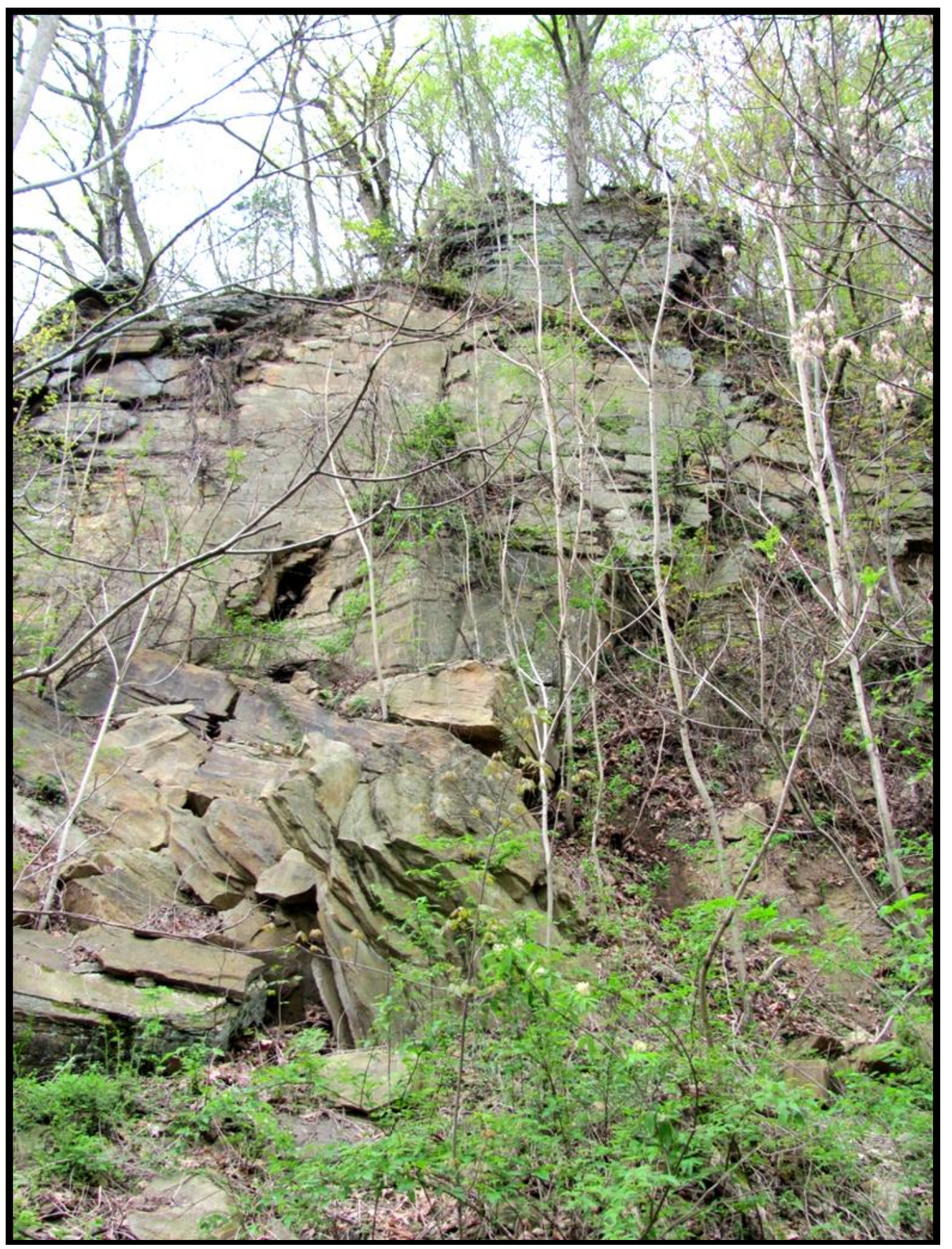

Appendix Figure 3. 7: Carex tonsa (Fernald) E.P. Bicknell var. rugosperma (Mack.) Crinsfound on a disturbed (e.g. manmade), incompetent cliff face 


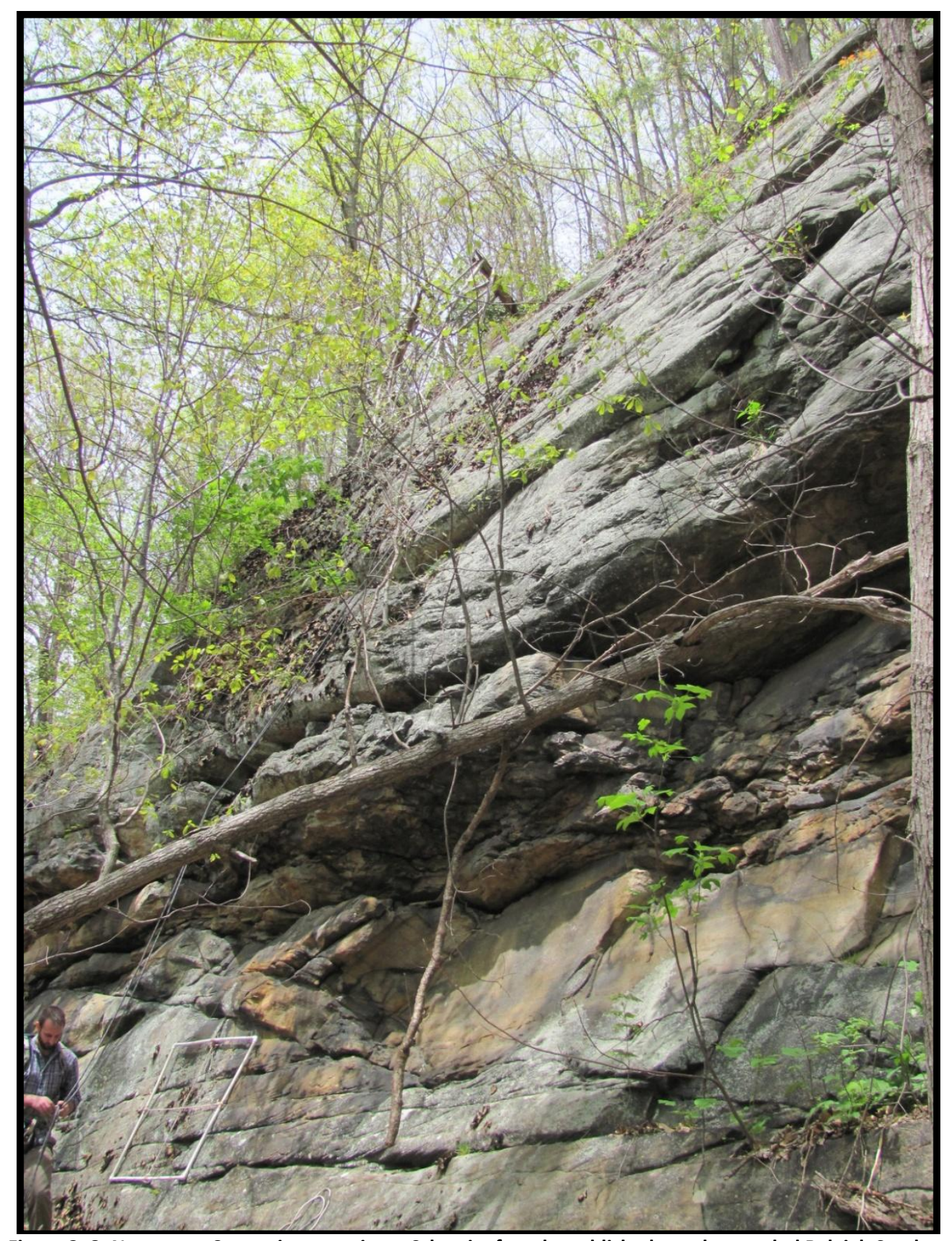

Appendix Figure 3. 8: Numerous Carex nigromarginata Schwein. found established on a low angled Raleigh Sandstone cliff (site N326.03) 


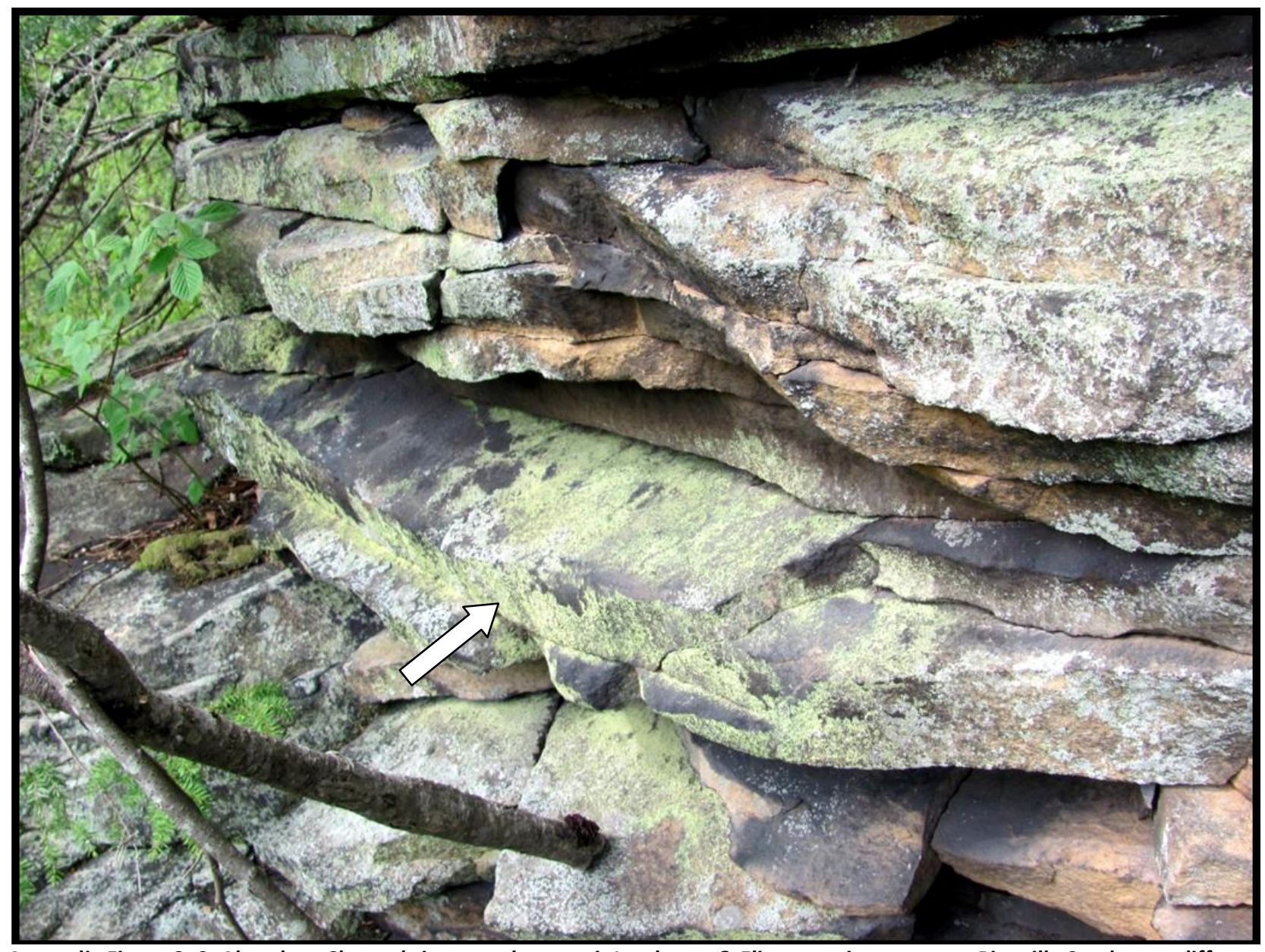

Appendix Figure 3. 9: Abundant Chrysothrix susquehannensis Lendemer \& Elix. on an incompetent Pineville Sandstone cliff face 


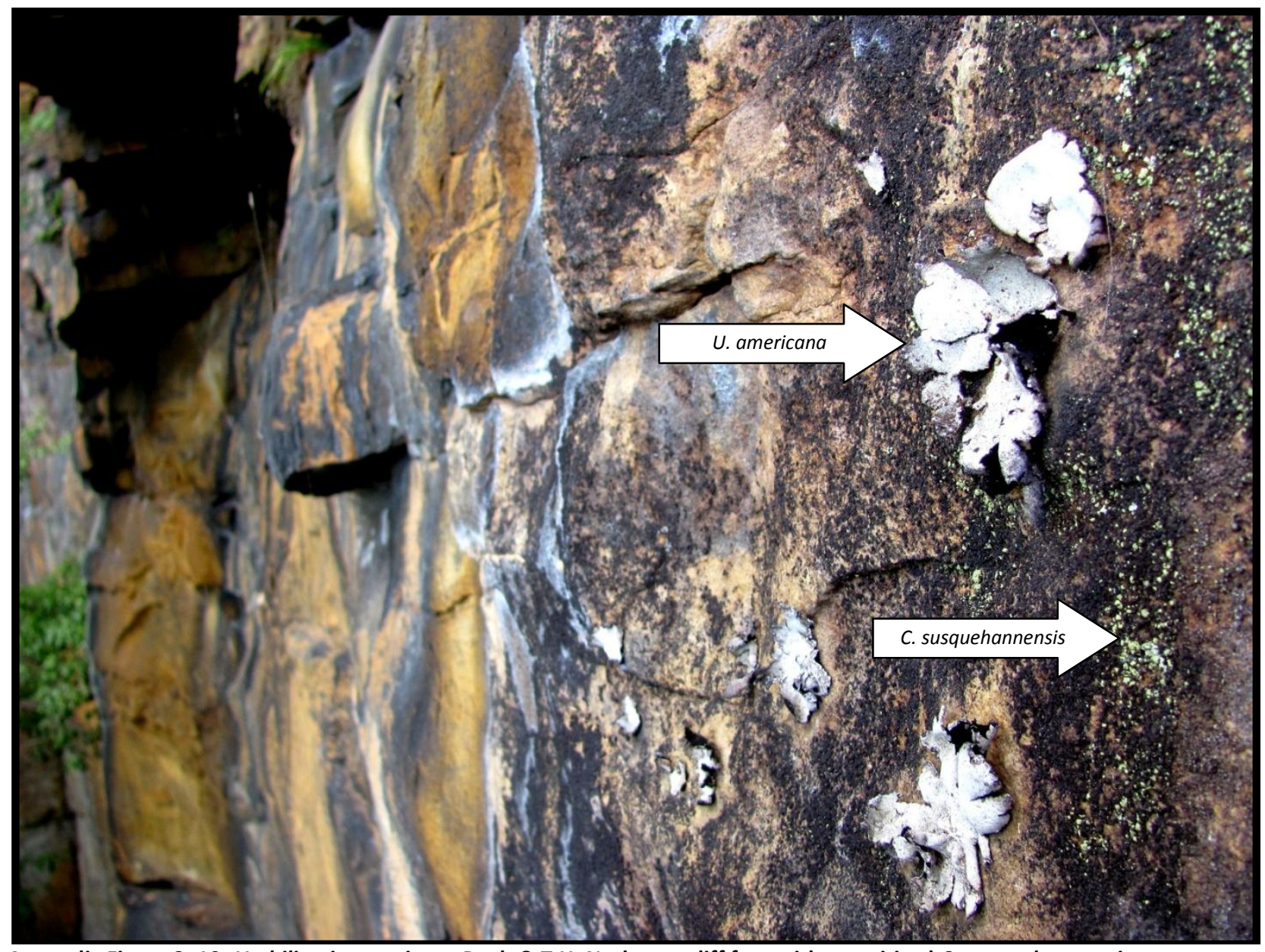

Appendix Figure 3. 10: Umbilicaria americana Poelt \& T.H. Nash on a cliff face with parasitized C. susquehannensis 


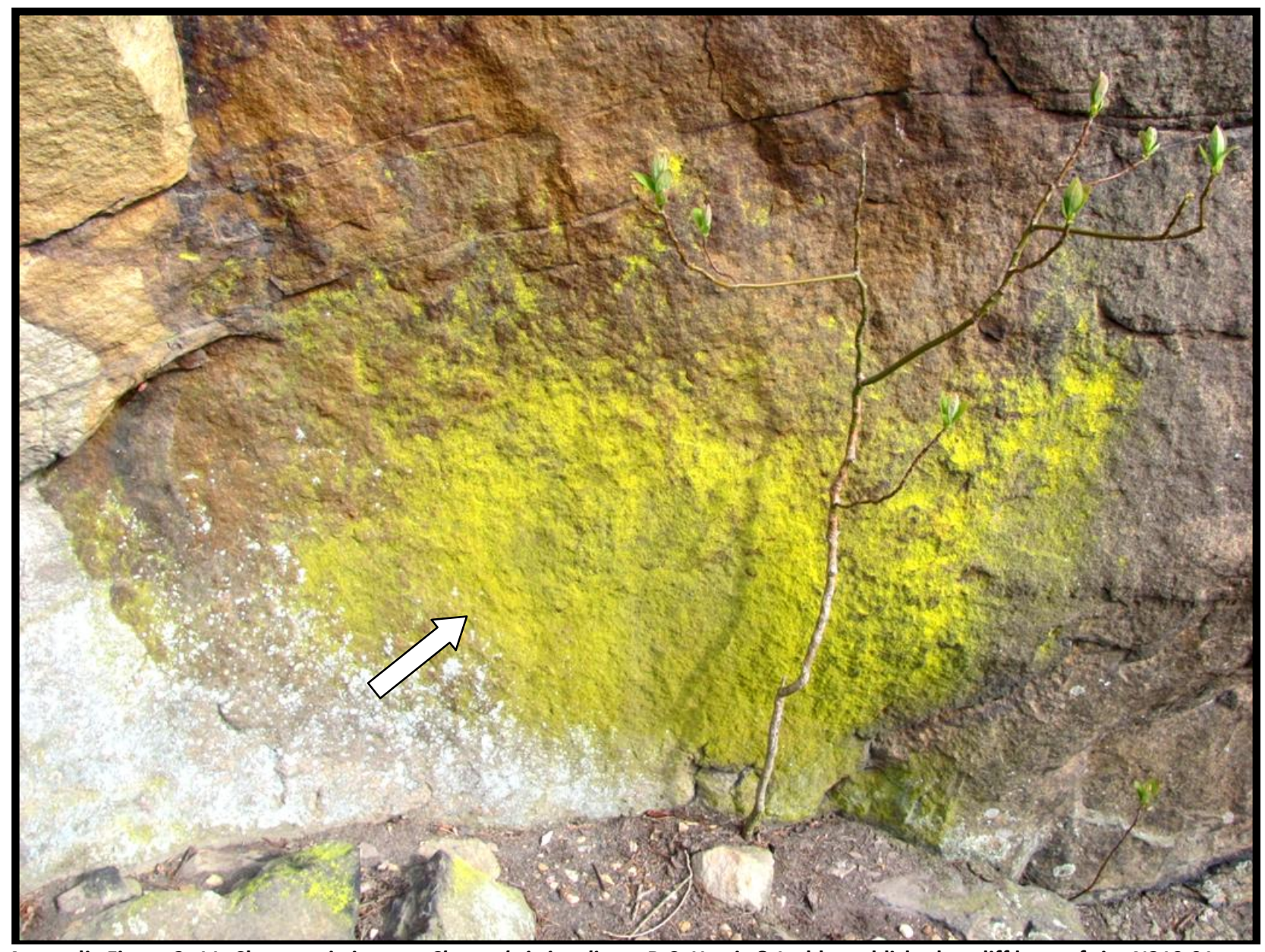

Appendix Figure 3. 11: Characteristic neon Chrysothrix insulizans R.C. Harris \& Ladd established at cliff base of site N319.01 


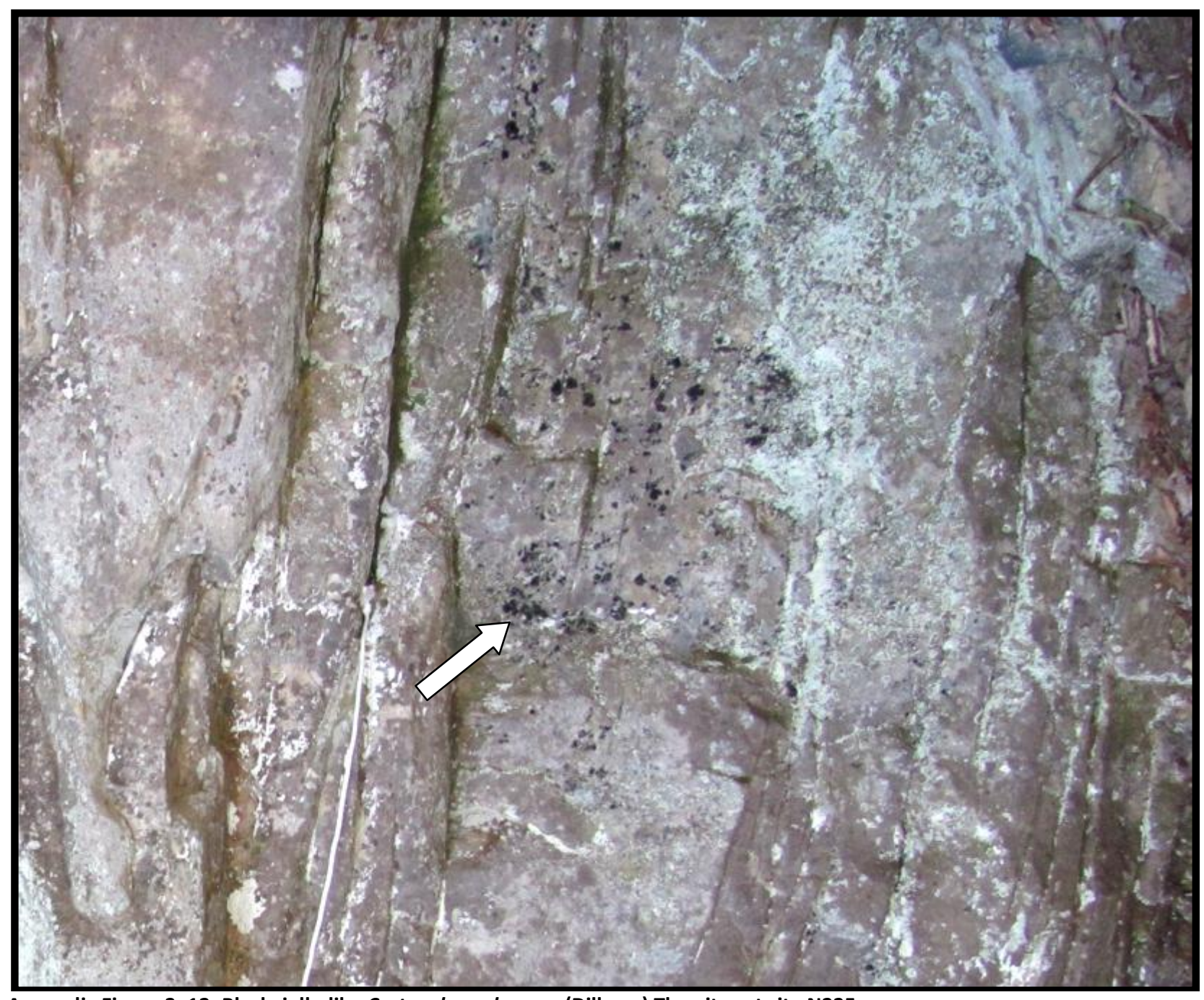

Appendix Figure 3. 12: Black, jelly-like Cystocoleus ebeneus (Dillwyn) Thwaites at site N225 


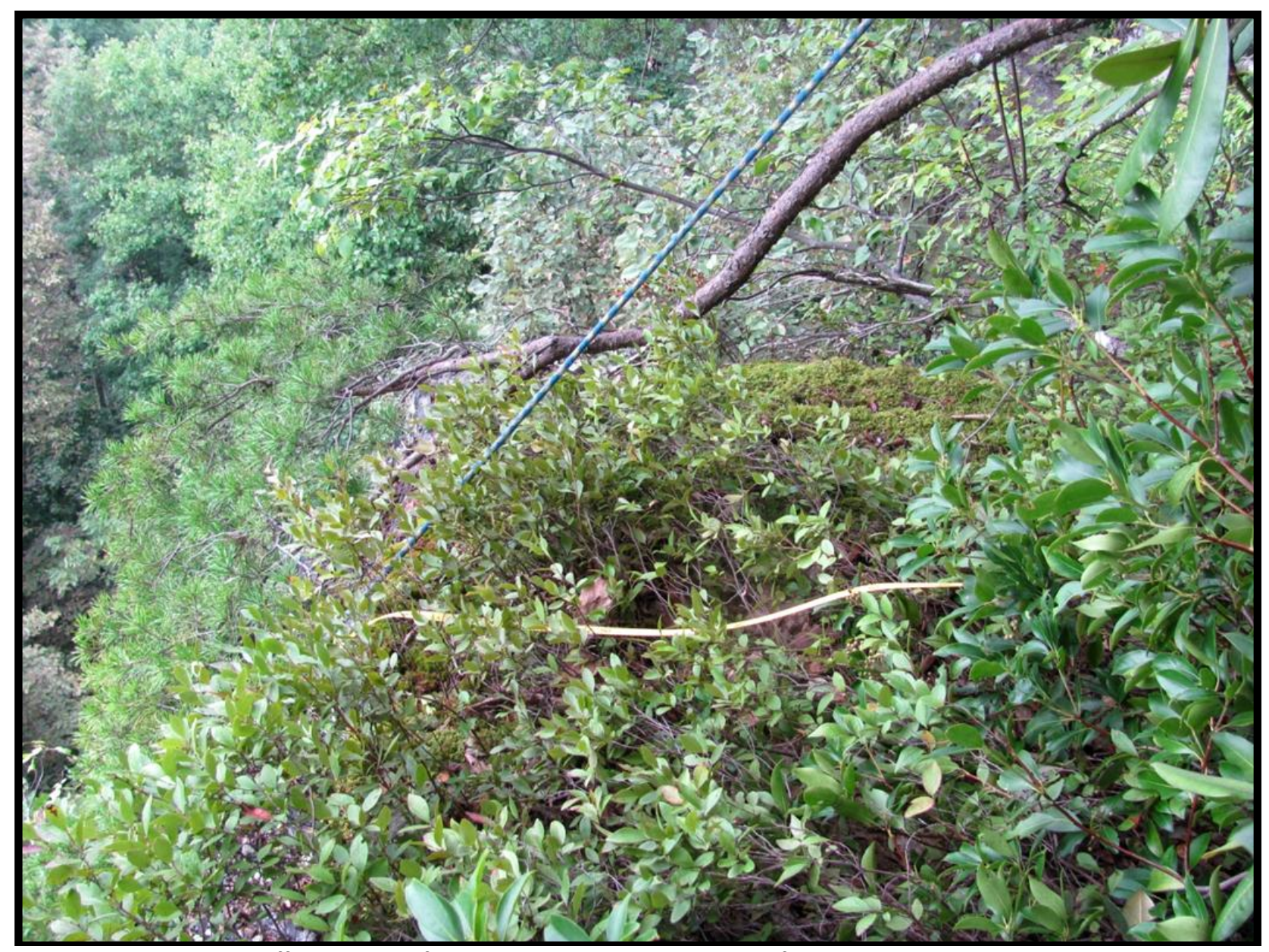

Appendix Figure 3. 13: Cliff top habitat for Dicranum condensatum Hedw. found in site N222, with Gaylussacia baccata (Wangenh.) K. Koch, and Kalmia latifolia L. 


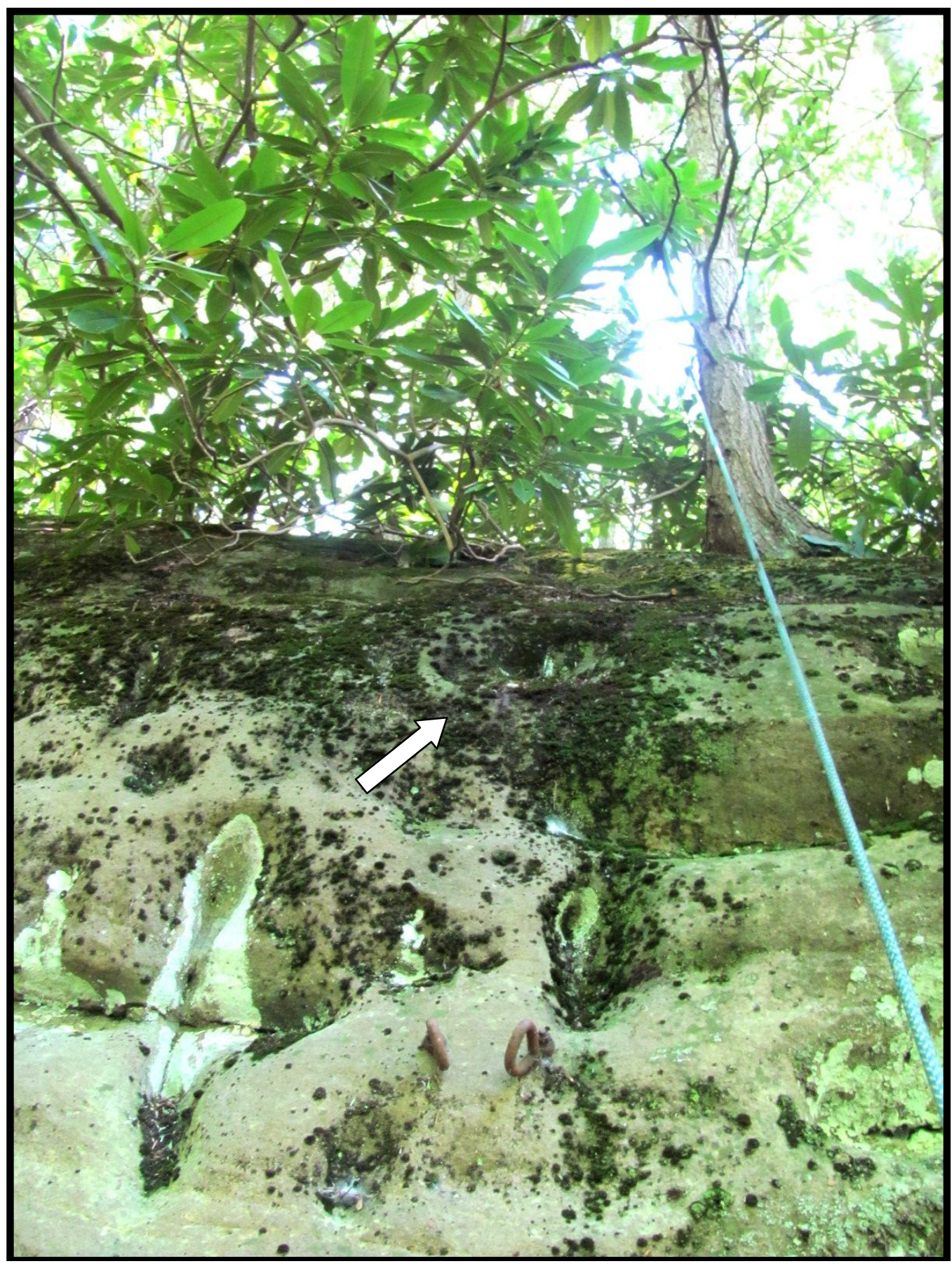

Appendix Figure 3.14 Andreaea rothii F.Weber \& D. Mohr established above rock climbing anchors in characteristic habitat 


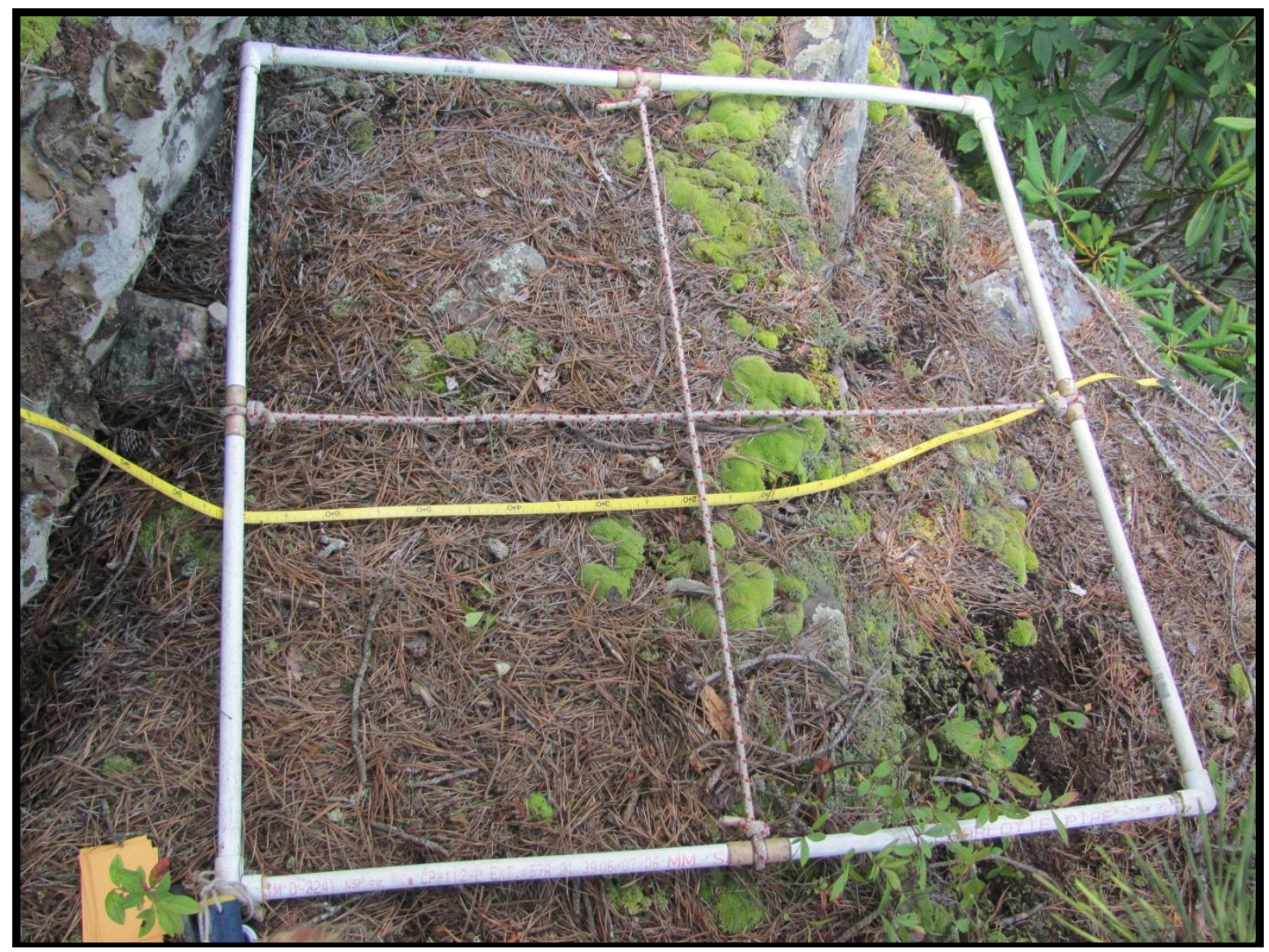

Appendix Figure 3. 15: Characteristic cliff top habitat for Dicranum spurium Hedw. found in site N228. Note most bryophytes present in picture are Leucobrym glaucum (Hedw.) Ångstr. 